University of Louisville

ThinkIR: The University of Louisville's Institutional Repository

Electronic Theses and Dissertations

$12-2008$

\title{
Advancing the knowledge of local health care policy through the growth machine thesis.
}

David P. Houvenagle 1965-

University of Louisville

Follow this and additional works at: https://ir.library.louisville.edu/etd

\section{Recommended Citation}

Houvenagle, David P. 1965-, "Advancing the knowledge of local health care policy through the growth machine thesis." (2008). Electronic Theses and Dissertations. Paper 641.

https://doi.org/10.18297/etd/641

This Doctoral Dissertation is brought to you for free and open access by ThinkIR: The University of Louisville's Institutional Repository. It has been accepted for inclusion in Electronic Theses and Dissertations by an authorized administrator of ThinkIR: The University of Louisville's Institutional Repository. This title appears here courtesy of the author, who has retained all other copyrights. For more information, please contact thinkir@louisville.edu. 


\title{
ADVANCING THE KNOWLEDGE OF LOCAL HEALTHCARE POLICY THROUGH THE GROWTH MACHINE THESIS
}

\author{
By
}

David P. Houvenagle

B.A., Iowa State University, 1987

M.Div., Bethel University, 1991

M.S.W., Southern Seminary, 1994

\author{
A Dissertation \\ Submitted to the Faculty of the \\ Graduate School of the University of Louisville \\ In Partial Fulfillment of the Requirements \\ For the Degree of \\ Doctor of Philosophy \\ Department of Urban and Public Affairs \\ University of Louisville \\ Louisville, Kentucky
}

December 2008 
ADVANCING THE KNOWLEDGE OF LOCAL HEALTHCARE POLICY THROUGH THE GROWTH MACHINE THESIS

By

David P. Houvenagle

B.A., Iowa State University, 1987

M.Div., Bethel University, 1991

M.S.W., Southern Seminary, 1994

A Dissertation Approved on

November 12,2008

by the following Dissertation Committee:

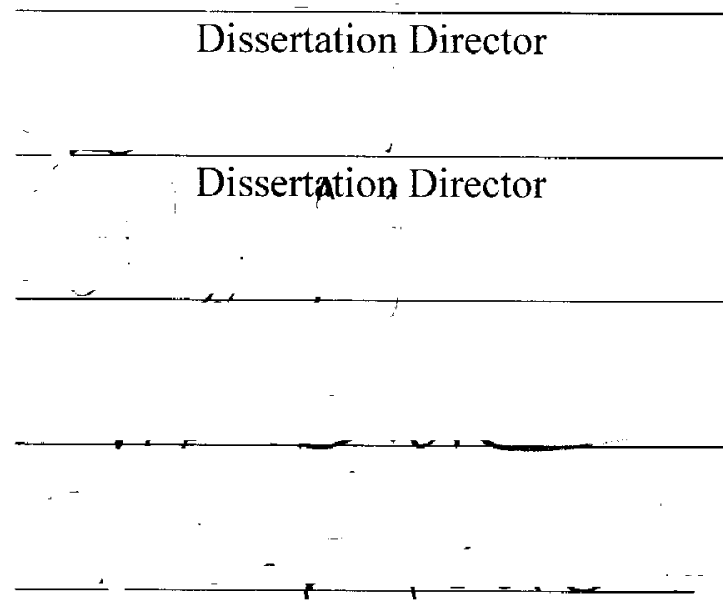




\section{DEDICATION}

To:

My parents Thomas and Shirley Houvenagle, who have financed this wonderful educational opportunity and who have encouraged me every step of the way,

and

I also dedicate this to the memory of my ancestor Benedict Houvenagle who had the ambition and courage to come over from Belgium to lowa in 1854 to better his fortune in the "New World." As a result he moved from being a mere livery stable hand to owning his own farm. He reminds me of the privilege I have in America to pursue dreams and be who I can be. 


\section{ACKNOWLEDGEMENTS}

Many people supported me, encouraged me, and prayed for me during the dissertation process. There are many that I cannot mention due to space constraints, but to the following, I give heart-felt thanks.

First, I thank the committee of Dr. Esterhay, Dr. Imbroscio, Dr. Sussman, and Dr. Vogel and Dr. Whitt for being on my committee. I especially thank Dr. Whitt for graciously tolerating me in 2005 and 2006 when I repeatedly came to his door for help with my dissertation idea and guidance on social network analysis.

I also thank all the interviewees/informants who gave me their time and thoughts on healthcare politics. In the process I had the awesome privilege of meeting some exceptional individuals who make Louisville, Kentucky a great city.

Also, thanks to the excellent archivists who helped me as I mined for historical information. Dr. Tom Owen at the University of Louisville Archives and Mr. David Morgan at the Louisville City Archives graciously gave invaluable assistance.

I had the great fortune to have three very good proof readers who worked quickly and gave me excellent feedback. Thank you Anne Faulls, Amy Mudd and Pam Soto!

I thank my program director, Jean Henry, LCSW and Gene Hardin, CADC--my clinical lead at Our Lady of Peace Hospital for allowing me to go out in the afternoons during the spring and summer of 2007 to conduct the field interviews. Thanks to my colleagues (especially Alice Clements CADC) in the Adult Partial Hospitalization 
Program for their support and for reading different drafts of chapters and giving me feedback. I also thank Purander Sarmah, Ph.D. and Laverne Wheatley-Terry, Ph.D. LMFT, for listening to my angst and for their insightful support.

Thanks to the different physicians who read my material and/or gave me moral support during my research and writing. These are Todd Bensenhaver, M.D., David Kissel, M.D., Michael Harris, M.D., Dante Morasutti, M.D., and Gary Weinstein, M.D.. There have been early supportive players present at the right times to give me feedback and encouragement. I thank Drs. John and Sharleen Birkimer (both U of L emeriti) for guidance when I applied for the Ph.D. program in 2001. I also thank my $9^{\text {th }}$ grade wrestling $/ 10^{\text {th }}$ grade football coach (and now an administrator) at Southeast Polk High School in Runnells, Iowa Stephen Miller, Ed.D for his advice, feedback and support throughout my whole program.

Of course I must thank my family. Words cannot even begin express my gratitude to Leslie, the love of my life and wife of 14 years (half of them in this doctoral program journey) for agreeing to this journey. I thank my children Aimee and Stephen for accepting when Daddy had to be upstairs in the office alone studying or writing and accepting watching videos in my home office as alternative daddy time too many nights. I must thank my parents, Thomas and Shirley Houvenagle, for their financial and emotional support during the past seven years.

Last but certainly the most; I thank God almighty also known as "Jehovah," "El Shaddai," "Elohim," and the "God of Abraham, Isaac and Jacob." In him I live and move and have my being. I thank him for the ability, opportunity and resources to do this. I testify that I have felt his presence and hand in this. To him be the glory! 


\section{ABSTRACT \\ ADVANCING THE KNOWLEDGE OF LOCAL HEALTHCARE POLICY THROUGH THE GROWTH MACHINE THESIS}

\section{David Houvenagle}

November 12,2008

A disciplined-configurative case study design was carried out to explore whether a growth machine exists and shapes local healthcare policy in Louisville. A historical analysis first explored whether a growth machine existed in Louisville in the past and shaped healthcare policy. Second, a network analysis was used to identify the recent contours of the Louisville growth machine. Third, qualitative interviews were conducted with central individuals as indicated by the social network analysis to assess the degree to which local healthcare policy is shaped and driven by the growth machine. The results show that Louisville has consistently had a growth machine which has shaped the limited local healthcare politics and policy allowed by the higher levels of government. The Federal Government's policy to require pluralistic boards of average consumers on public health agencies actually has detached the growth machine as the local power structure from those agencies. The growth machine has not always had consensus due to differing growth agendas as demonstrated by the construction of Southwest Hospital, the break up of the University of Louisville Hospital management consortium, and the reorganization of the Louisville Medical Center Development Corporation. Regardless the growth machine has generally been able to keep the general public out of such decisions and in 
turn find new ways to be unified in the name of growth. Local government in Louisville was and continues to be a supportive player versus dominant player in the growth machine in local healthcare politics and has not been the driver of local healthcare policy. 
TABLE OF CONTENTS

PAGE

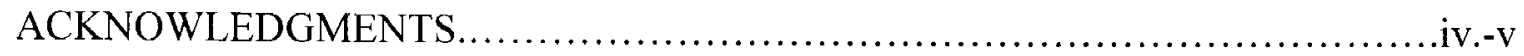

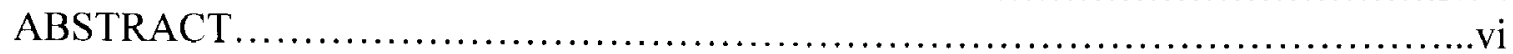

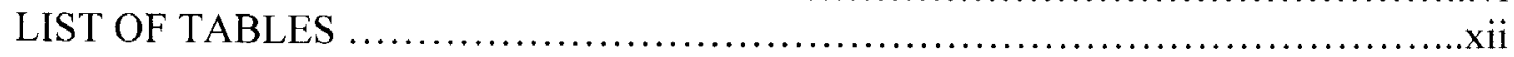

CHAPTER

I. QUESTION OVERVIEW AND INTRODUCTION TO THE STUDY.....1

Overview......................................................

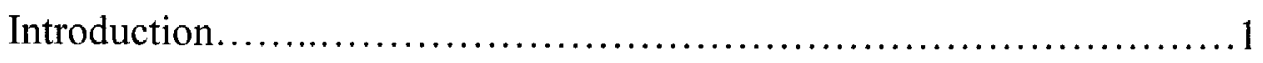

Scope and Significance of the Analysis..............................

An Overview of the Problem...........................................

Clarification of the Local Aspect.....................................

What are Local Politics?.................................................................6

The Matter of Policy...............................................

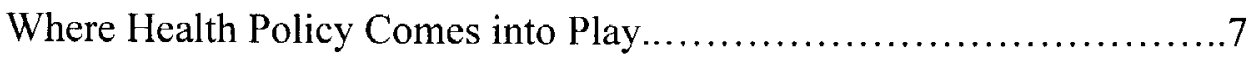

Research Methods.................................................

An Overview of the Study......................................... 16

II. A PRIMER ON THE GROWTH MACHINE THESIS ..................18

A Definition of the Growth Machine Thesis ........................... 18

Historical Background of the Growth Machine Thesis ...................24

A Survey of the Relevant Research on the Growth Machine Thesis .....33 


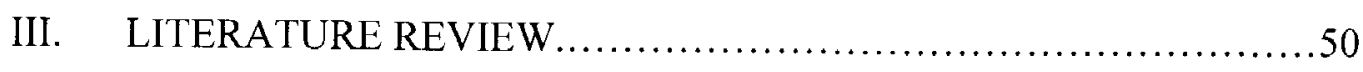

Early Sociological Studies............................................50

Health Policy Studies..............................................53

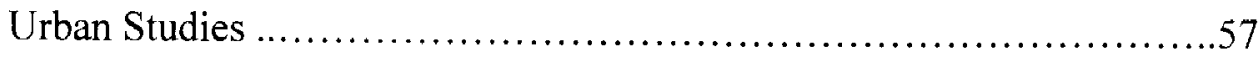

IV. HISTORICAL ANALYSIS PT \#1:

THE LOUISVILLE MEDICAL CENTER ............................ 63

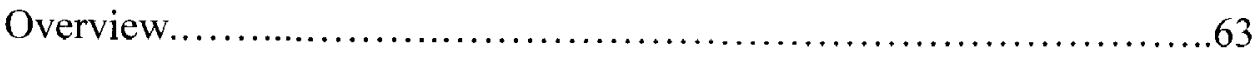

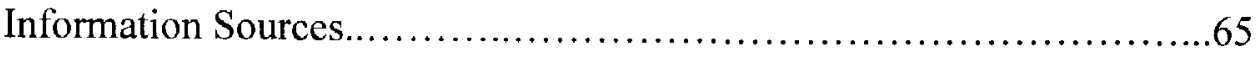

The Louisville Medical Center Development Process.....................67

The Saga of Methodist Evangelical Hospital.............................80

Conclusion and Analysis......................................... 87

V. HISTORICAL ANALYSIS PART \#2: THE TRAJECTORY OF HEALTHCARE PLANNING IN LOUISVILLE FROM 1966-1983 ......90

Overview............................................................... 90

Information Sources..................................................91

A Model of Trajectory............................................91

Available Information from Field Interviews about the LHFC/FRHC

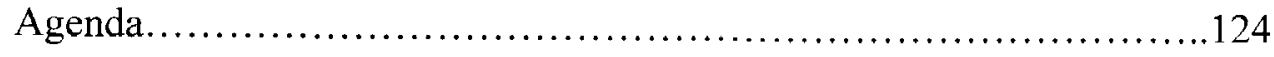

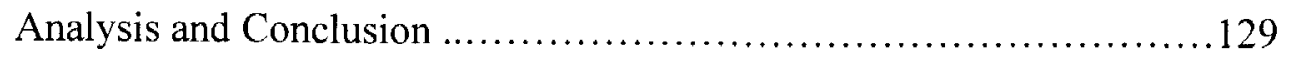

VI. A SOCIAL NETWORK ANALYSIS OF THE HEALTHCARE POLITICAL NETWORK STRUCTURE IN LOUISVILLE, KY BETWEEN

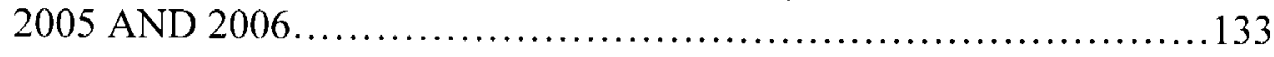

Introduction......................................................

A Brief Discussion and Critique of SNA................................135

Utilization in This Study of SNA Tools ...................................................138 
Data Collection and Cleaning Issues.....................................................138

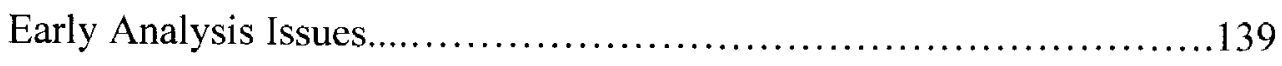

Centrality Analysis Results.......................................141

Clique Analysis....................................................

Analyses of the Network in Terms of Sectors.........................154

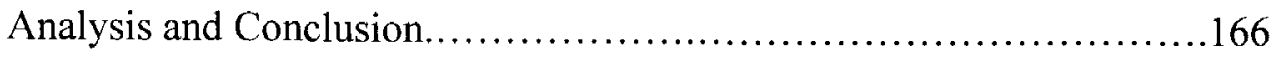

VII. RESULTS OF ELITE INTERVIEWING ..........................171

Introduction......................................................

Informant Selection and Conduct of Interviews..........................175

Thematic Summations of Answers to Questions........................181

Who are the Players in Local Healthcare Politics?....................................182

What is the Agenda of the Local Players?................................................191

The Manner of Communication and Implementing Policy.................193

The Matter of Organizational Interlocks and Political-Economic Tension.194 The Unique Case of the getCare Network............................204

The Lack of Network Connection between the Public and Public Sectors.206 The Closing of Southwest Hospital and Relocation of Its Beds...........207

Conclusion............................................................

VIII. SUMMARY AND CONCLUSIONS.................................214

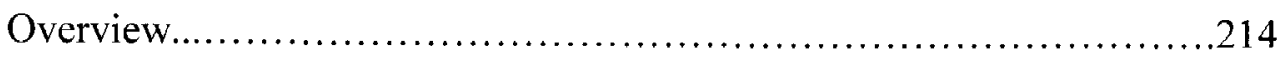

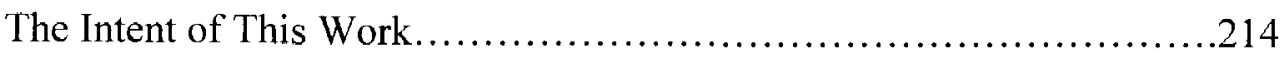

Lessons from the Research........................................218

Suggestions for Future Research...........................................................221 
Important Considerations in Duplicating This Research...................228

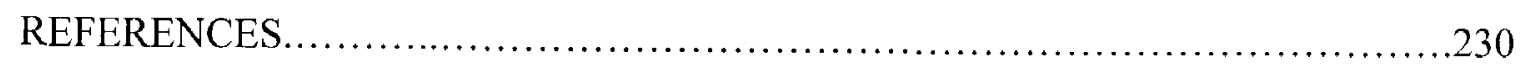

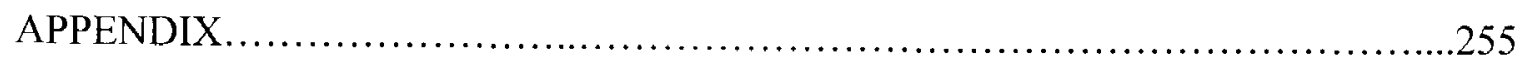

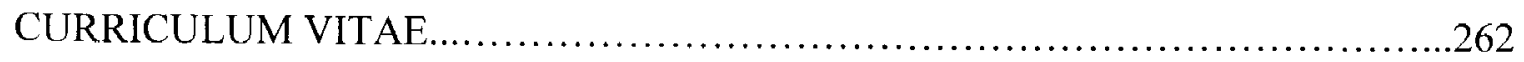




\section{LIST OF TABLES}

TABLE

PAGE

1. The Players of the Growth Machine ..............................................20

2. Meeting participants-Louisville Area Development (LADA) Special Committee on

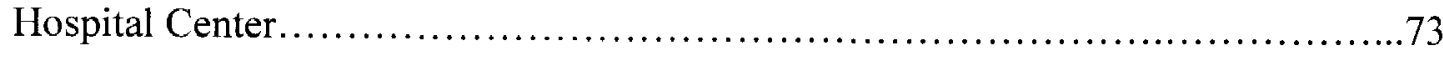

3. Initially published roster of the Louisville Area Health Facilities Council (LHFC)...95

4. Additional LHFC members as identified in Courier-Journal stories..................96

5. Initial members of the Falls Region Health Council, January 1970_................98-99

6. Kentucky Health Systems Agency West, Board of Directors 1979..............102-103

7. Top 20 Bonacich Eigenvalues for Louisville Organizations in $2005 \ldots \ldots \ldots \ldots \ldots \ldots 145$

8. Top 20 organization Bonacich Eigenvalues after Greater Louisville Inc (GLI) is removed from the dataset..................................................... 146

9. Top 20 individual Bonacich eigenvalues in 2005 with their economic sectors.......148

10. Individual Bonacich eigenvalues after Greater Louisville Inc (GLI) cases were

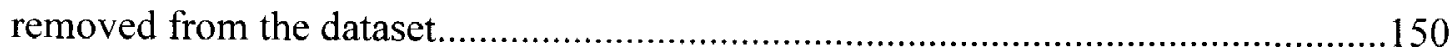

11. Clique $\# 53$ with highest average Bonacich eigenvalue score with sectors..........153

12. Clique \#106 with second highest average eigenvalue score with sectors..........154

13. Non-metric Multidimensional Scaling (MDS) coordinates of sectors in Louisville

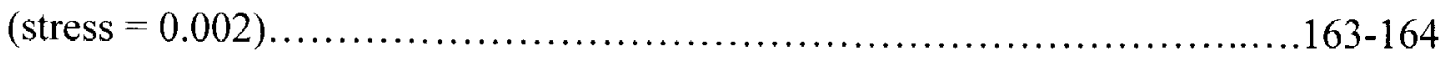




\section{CHAPTER I}

\section{QUESTION OVERVIEW AND INTRODUCTION TO THE STUDY \\ Overview}

This chapter will introduce the research question(s), the suggested theory, and the research methods chosen for analysis. It will discuss the scope and significance of the analysis. It will orient the reader through 1) the use of terms and concepts to be used in this study, and 2) the definition of city politics. It will conclude with a description of the study.

\section{Introduction}

This dissertation is a community-wide power structure analysis of healthcare governance at the local or city level in Louisville, Kentucky. The intent is to test whether the growth machine thesis can explain the power structure and activity of local healthcare politics in Louisville, Kentucky. The growth machine thesis is a political-economic theory describing political structure and activity at the local level. The research questions are: 1) is there a growth machine in Louisville, and 2) does it shape local healthcare policy.

\section{Scope and Significance of the Analysis}

Lennarson-Greer (1997) created awareness of the dearth of research and knowledge about the local aspect of healthcare politics in her article about urban health politics. For Lennarson-Greer, 
Urban health politics and policies attempt to define and fulfill the responsibilities of cities for the health of their population, especially in regard to the hazards and dangers of urban life and the uneven concentration of disease in cities (p.356).

She noted that both urban studies scholars and health policy scholars have ignored this policy area in general. She observed "while responsibility for health and health care is fundamentally local, it is rarely the focus of 'urban' research and almost never reflects urban social or governmental theory" (p.356). She noted that there has been mutual ignorance where urban scholars have ignored health issues, and health researchers have ignored the local or "place" aspect of health issues (p.357). This is an area that has had little political research in the past 40 years, and the body of available political research is scant; this dissertation seeks to identify new objects for study.

This study is delimited, in that it will explore only the first half of LennarsonGreer's definition of urban health politics as cited above. There are significant, yet basic questions about identity of the political actors in this area, what drives their agendas and how they act. It is necessary to provide some framework for understanding the political environment or context by probing such matters as the hazards and dangers of urban life and the uneven concentration of disease in cities.

This study is also delimited by its focus on the political structure and human agency issues. It is believed that from these results, understanding the relationships between "individual health," "healthcare," "public (population) health" and "urban planning" appears to be a matter for future research as discussed below in the problem statement. The intention is to answer questions while building a robust base for the future research of such matters. ${ }^{1}$

\footnotetext{
${ }^{1}$ It is hoped that the results of this dissertation can lead others to frame a context that includes the relationships between individual health, healthcare, public (population) health and urban planning. It is
} 
The research design of this dissertation is a disciplined-configurative case study design that also serves as a community-wide power structure analysis (see Domhoff and Dye 1987). This dissertation appears to be the first study to describe the place aspect of local healthcare politics and the derived policy from those politics in terms of social and governmental theory. This study also seeks to bring attention to the relevance of urban political economy as a useful analytical tool for health-related disciplines to improve strategic planning on the local level.

\section{An Overview of the Problem}

When it comes to the United States, little is known about the power structure of local healthcare politics. Lennarson-Greer observed:

Research from the vantage point of medicine and health services focuses on diseases, treatments, and healthcare resources (facilities, personnel) as if these were not embedded in local realities, as if their existence and functioning were not intrinsically a reflection of local history and local decisions (p.356).

Bazzoli, Gerland, \& May (2006) are an example of this conundrum as they attempt to explore what is motivating the increase in hospital construction. They look at some cities, but do not analyze the local political situations in those places. The sum of the articles in Journal of Health Politics, Policy and Law also follow the pattern observed by Lennarson-Greer. ${ }^{2}$ Thus when it comes to attention given to healthcare politics, the national and state levels have received almost all the scholarly and media attention. An initial, fundamental conclusion is that the political activity has tended to cluster around the funding or financing source-mainly the national government. Authors such as Leichter (1979) focus their comparisons and debates on the national

otherwise missing from the literature because health policy scholars have ignored the local context as Lennarson-Greer identified.

${ }^{2}$ A review of this journal back to 1990 revealed no string or pattern of research on the local place. 
stage advocating that level is where the change should be. ${ }^{3}$ Also, universal health care as a favorable policy has been gaining momentum in the United States since the early 1990's with the Clinton Presidency.

However, the US healthcare system is actually more of an industry based on market processes than on government policy. Shi and Singh (2008) note that government is "subsidiary" to the private sector (p.536). They note that the private sector plays a dominant role and that "Americans generally prefer market solutions as opposed to government intervention in health care financing and delivery." Shi and Singh also note that government healthcare spending has been mostly confined to filling in gaps left by the private sector (p. 537). What is most interesting is Shi and Singh's observation that "Federal, state, and local governments pursue their own policies with little coordination of purpose or programs" (p.538).

Nevertheless, the federal government is the largest payer-source for healthcare in the US and sets rules for getting the money. Lobbying federal lawmakers to influence healthcare regulations and funding is an industry in its own right.

Parts of the federal bureaucracy have political power in terms of determining clinical standards and administrating the dispersion of funds in accordance with federal laws. While subject to congressional oversight, federal bureaucrats are the prime interpreters of how federal regulations are to be implemented and they follow through as such. The United States Food and Drug Administration (FDA) receives a great deal of attention through its regulatory and administrative powers in healthcare to approve medications and medical procedures without Congress' approval.

\footnotetext{
${ }^{3}$ Leichter's book compared healthcare policy in Germany, the United Kingdom, the former Soviet Union, Japan, and then stated implications for the United States. His analysis was strictly at the national level and
} 
State healthcare politics also gets significant attention, albeit as much for its designated roles in healthcare. Each state is in charge of licensing of both professionals and facilities within their geopolitical boundaries. States directly provide healthcare for individuals with severe and chronic needs through state-owned hospitals and facilities. The states also finance non-profit facilities and privatize some services when it is in the state's interest to do so. Furthermore, state governments also are gatekeepers for the federal funds spend on healthcare such as Medicaid within their geopolitical boundaries. In the federalist system of government in the United States it seems that federal and state healthcare politics are fairly well defined and understood — but this is not so with local healthcare politics in the United States.

\section{Clarification of the Local Aspect}

This dissertation asserts that the local aspect refers to the area of local politicsspecifically the pertinent political power structure, the political activity, and the unique policy issues. This is a fundamental concept that has been missed by health policy scholars.

Today, local healthcare mostly operates in a metropolitan context (this is especially true for Louisville). Today's metropolitan context consists of a central city surrounded by suburbs.

In the United States a city ${ }^{4}$ is an incorporated governmental entity as chartered by the government of the state in which it lies. It is a creation of the state or local

\footnotetext{
did not consider the local level.

4 Mumford (1937) defined a city as "a geographic plexus, an economic organization, an institutional process, a theater of social action, and an aesthetic symbol of collective unity" (p.94). Further definitions from Pirenne (1925) include a locality dedicated to commercial activity, and a "center of administration and as a fortress" (p.56). A city in and of itself has a spatial dimension in that it occupies a specific space and has legal, economic and social cohesion occurring within that space.
} 
metropolitan area in a distinct geographical territory with specified legal limits/boundary

lines. Cities exist within a larger legally defined territory called a county ${ }^{5}$, which is also a creation of the state. A city is beholden to the laws and rulings of the higher levels of government. A number of scholars recognize that cities therefore exist within a structure. ${ }^{6}$ Cities must change when the larger structure is changed as cities have limits to power.

\section{What are Local Politics?}

Within the federalist system of the United States, local politics is distinctive in that it has a limited nature. Peterson (1981) observed that local politics is not national politics and that local politics are "most limited." He also stated that what power exists in a city is exercised within constraints and that the processes are very different than what happens in national political processes (p.3-4). Stone (1987) also agrees in part with Peterson that local government officials must make choices within "structural boundaries" (p.4). Drier, Mollenkopf and Swanstrom (2001), also note that there are "stark limits" to the political abilities of localities to address problems within their geopolitical borders (p.171). Urban scholars from different points of view agree on the concept of limitation but disagree on the amount of political autonomy that cities have. ${ }^{7}$

\footnotetext{
${ }^{5}$ Louisiana calls its counties "parishes."

${ }^{6}$ Kleinberg (1995) provides some ideas on how the larger structure of federal policy caused the big cities to sprawl outside their boundaries. ${ }^{6}$ One way it occurred was as a reaction to federal housing policy. The Federal Housing Administration (FHA) encouraged private ownership through incentives to bankers to lend money by insuring loans. The majority of those loans have been made in suburban areas (pp. 113115). Another way Kleinberg saw federal policy incite sprawl was through highway policy - particularly through the "Interstate Highway Act of 1956." The mass transit policies of localities were superceded by the federal Government policy of creating freeways and expressways in and out of cities to new housing developments outside city limits that needed no connection to trolley or train routes into the central cities (pp.128-130).

${ }^{7}$ Peterson's definition has been repeatedly quoted in the literature for his useful phrasing of local politics being limited, but as Stone (1987) states, Peterson took most of the politics out of city politics given Peterson's view that cities have a limited, unitary interest in pursuing developmental policies (p.5). Dreier, Mollenkopf and Swanstrom come at local politics from a very different point of view, emphasizing federal
} 


\section{The Matter of Policy}

Understanding the essence of local healthcare politics also means understanding the product of the political activity, which is policy. Anderson (2000) defines policy as "A relatively stable purpose or course of action followed by an actor or set of actors in dealing with a problem or matter of concern" (p.4). Not all that is called policy is deliberately conceived and implemented for rational outcomes. Many existing policies are usual and customary practices that may or may not be formally approved by the appropriate legislative, judicial or executive authority in the act of governance. ${ }^{8}$ For example city administrators or street-level bureaucrats may make routine decisions within their bounds of authority and judgment. Any which way, the more a routine decision or process is repeated, the more it becomes institutionalized policy in the form of usual and customary practice even if it is never officially codified into laws and regulations.

\section{Where Health Policy Comes into Play}

Moran (2006) purports that there are three different frames of reference in which health policy can be observed: social policy, labor market policy, and industrial policy. The social policy frame of reference concentrates on welfare entitlements and consumption. The labor market frame of reference focuses on supply of workers and education to train the workers. The industrial frame of reference pertains to technological developments. Moran notes that the frame of reference depends upon the researcher's emphasis (pp.221-223).

policy and state policy being responsible for what has happened within cities and eschewing Peterson's public choice or free market leaning. The point of all of this is that scholars from diverse backgrounds at least agree that local politics are limited.

${ }^{8}$ Stoker acknowledges that Governance is synonymous with Government but in urban studies its usage has an informal connotation. Stoker (1998) states that governance is concerned with creating the conditions for order and collective action. (pp.17-18). Pierre (1999) purports that governance should be understood as a blending of private and public interests aimed at enhancing collective goals (p.374). 
On the other hand, Moran also notes that states ${ }^{9}$ are crucial actors and shape the frame of reference. While the states play a role in welfare consumption, the labor market and the industrial or technological sectors, they operate differently in their respective domains. Moran observes that a systemic relationship exists between healthcare organizations and the states. Healthcare organizations are embedded within the geopolitical boundaries of the states and are subject to the power of state governments to shape institutions. A different perspective is that those same healthcare institutions have ... a shaping influence on their surrounding environment. They amount to large scale concentrations of interests, economic activity, and, often, electoral muscle, and in these guises intervene in the wider shaping of policy (p.223).

While Moran's observations come from a national government context, his observation about healthcare policy is similar to Kleinberg's (1995) overall policy statement regarding the nature of a larger structure in framing local politics in the United States.

Given the embedded nature of a city, it has limitations placed on it within the larger structure. These limitations are the kinds of policy it can make and the power it has to make those decisions through both fiscal and legal constraints. For the non-urban scholar, Peterson (1981) offers a useful understanding of the three limited types of policy options cities have: developmental, allocational, and redistributive (pp.41-65). ${ }^{10}$ Developmental policies are those plans and practices designed to improve the economic standing of the city. Developmental policies should offer a return on investment and benefit the whole community with gains. Allocational policies are those policies Peterson called "housekeeping" services to include garbage collection, fire protection,

\footnotetext{
${ }^{9}$ Moran is an author from the United Kingdom and his usage of state appears to refer to national or central governments and not the 50 states of the United States.
} 
and police protection. Allocational policies should be of good value to the community for the money spent. Redistributive policies actually benefit the low income residents of the community and not the whole community and in Peterson's frame of reference, "negatively affect the local economy" (pp.41-42). ${ }^{11}$ Local politics will be about these three policy arenas within a city's structural limits.

Based on the those tenets of local politics in general, some statements of synthesis can be suggested regarding what is expected of local healthcare politics and the nature of the policy made at the local level. Local healthcare politics in the United States must reflect the larger system and structure, which is a market system with the government being more of a secondary player. Second, localities are only able to make policy decisions within their power pertaining to healthcare as allowed by the higher levels of government; they cannot usurp federal and state guidelines such as approve new drugs and procedures like the FDA or license physicians like the state medical board. So among those limited options, localities are going to choose policies that are in their interests whether they are redistributive, allocational or developmental.

Identification of the policy makers and what drives their agenda is another question. At best, only one effort was found to describe what exists at the local level in terms of healthcare policy and politics. Dye (1973) proffered:

In nearly every community, decision making in health and hospital matters is firmly lodged in the hands of leaders of the local medical associations. These local physicians, men of prestige and influence in community leadership structures, believe that questions of public policy should be determined

\footnotetext{
${ }^{10}$ Bingham (2003) argues that political scientists are interested in the outcomes or how economic development policies are formed while economists are concerned with the impacts of policies. (p.242) An example of an impact is return on investment (ROI). This dissertation is not focused on impacts.

${ }^{11}$ In terms of ratios, developmental policies mean $\$ 1$ spent $<$ value received. Allocational policies mean $\$ 1$ spent $=\$ 1$ value received ratio. Redistributive policies mean $\$ 1$ spent $>$ value received in return. Peterson suggests that cities will pursue those policies within their interests.
} 
predominately by the doctors as a group, through their local medical society (p.479). ${ }^{12}$

The context of Dye's statement is that of explaining all the different aspects of local politics. Dye's emphasis is politics and not healthcare. However, there is a need to test if Dye is correct as to whether the physicians are the makers of such policy in the local community. ${ }^{13}$ As will be explored in the literature review, there are a narrow range of vague answers as to who makes the limited healthcare policy decisions for the community. Assuming the growth machine thesis is correct, it is expected that the local actors actually making the limited healthcare policy decisions as allowed by the larger levels of government will be members of the growth coalition.

\section{Research Methods}

This dissertation employs a "disciplined-configurative" case study approach. Specifically a power structure analysis is employed, utilizing a network analysis to test and extend the growth machine thesis to local healthcare politics and policy. The Louisville, Kentucky Metropolitan Area is the unit of observation. This section discusses the rationale for this methodology, the research design, the data collection process, the coding procedure, and the strategy for analysis.

\section{Disciplined-Configurative Case Study Description}

For a researcher's outcomes to be valid, purpose and objectives must guide the researcher's choice of method. This study is based on a particular theory that makes

\footnotetext{
${ }^{12}$ This appears to be Dye's opinion as he did not cite any research supporting this statement and Dye avoided making any such similar comment in a later edition of the book Politics in states and communities that was available for review.

${ }^{13}$ There is a matter of whether there has been a shift in influence from local medical associations to healthcare organizations.
} 
general statements about local political structure and activity. Given the broad task, a case study design is indicated.

Orum, Feagin and Sjoberg (1991) assert in general that a case study design allows for examination of "the whole complex of life" and "the impact on beliefs and decisions of the complex web of social interaction." According to Snow and Anderson (1991) a researcher using a case study design can conduct holistic analyses of networks of activity, contextualize activities and issues, triangulate research strategies, capture longitudinal social processes, and utilize open-ended questions to get broad answers from informants (pp. 152-163). This being said, there are different types of case studies, and for the purposes of this study, the "disciplined-configurative" design is the most appropriate.

According to Eckstein (1975) a "disciplined-configurative" case study is a design where situations are interpreted in terms of general laws and not on one particular point (p. 99). Eckstein notes that a case can "impugn" a theory if the theory should fit, but does not. The researcher can judge by the evidence in the case study whether the theory fits and is not bound to blindly accept the theory.

So, given the research question and goals, the most appropriate research design is the "disciplined configurative" type of case study. Eckstein described this design as a way to help knowledge become nomothetic or rule-bound. It may also point up a need for new theory in neglected areas (p.99). The subject of this dissertation is in a neglected area and this dissertation is out to test whether a theory is a fitting explanation for an unexplained phenomenon and to advance knowledge.

This case study has two main research questions.

1) Is there a growth machine in Louisville? 
2) Does it shape local healthcare policy?

The secondary research questions will be explored in a step-wise fashion. First, some of the answer will be obtained through the results of a social network analysis of a snowball analysis of public information. The social network analysis will provide suggestions of a political power structure. Second, answers will come from interviews of the most central individuals as identified in the social network analysis who gave information about how policy is shaped and for what reason it is shaped.

Historical Analysis

The first part of this case study is a historical analysis reviewing pertinent histories, archival documents, and newspaper articles from the 1940's through the 1980's. The historical research is guided by the questions:

1.) Who was involved?

2.) Were the growth coalition sectors represented among those involved?

3.) What did they do?

4.) Was there any discernible agenda?

5.) How did they carry out their activities?

This historical analysis will be reported in two parts. The first part will be the organizational process of the Louisville Medical Center from 1945 through 1955 and how the growth coalition started the process and dominated the process. The second part will discuss the historical trajectory of the Louisville Health Facilities Council and its successor organizations will be reviewed and analyzed. This type of analysis has some precedence (see Calavita, 1992 in providing useful information about the activity of a growth machine). 


\section{Social Network Analysis}

The second part of this case study design is a Social Network Analysis (SNA) of the management and boards of the healthcare and related organizations in the Louisville Metropolitan Area. This section is also the first portion of the power structure analysis. This method has the ability to test whether or not there is any kind of coherent, documentable relationship between the individuals and sectors in a community.

Whitt (1989) suggested using SNA as a way to test the growth machine thesis.

Whitt stated that if Molotch's argument is true

one would expect to find interorganizational networks among progrowth forces and between these forces and public agencies - networks that fuel the political engines of growth at the local level (p.99).

Whitt believes that using SNA techniques combined with the urban growth perspective "holds as its main promise the understanding of the political and social dimensions of urban growth (p.106). There has been no identified research since 1989 (when Whitt wrote this) to use SNA as a way of testing the growth machine thesis.

\section{Field Interviews ${ }^{14}$}

As part of the power structure analysis elite interviews were conducted to triangulate the results of both the SNA, and the content analysis. Field interviews were conducted to answer the five subsidiary questions. The interview component design and tentative questions were submitted to the University of Louisville Institutional Research Board for approval and received "Exempt" status approval.

The majority of the informants were primarily chosen from the Bonacich Eigenvector analysis portion of the SNA. ${ }^{15}$ The Bonacich Eigenvector Centrality

\footnotetext{
14 This was suggested by Whitt (1989) as a necessary adjunctive to SNA as a way of researching the growth machine thesis "to uncover intentions" of the elites (p.105).
} 
algorithm is a recognized indicator of prestige (Wasserman and Faust, pp. 175, 208-209)

and so it was the first criterion in selecting informants. The second criterion for selecting informants was based on membership in the two cliques with the highest average Bonacich Eigenvector scores. Together these two standards suggested that the informants had knowledge of political activities, people, and agendas. ${ }^{16}$ Other informants not selected through Bonacich Eigenvector results were selected later according to pertinence and reputation as recognized by the first group of informants.

A total of 22 informants were successfully interviewed. The interviews were conducted in several different places and were recorded with a tape recorder. The majority of interviews were held in the workplaces of the informants. Two interviews were conducted in alternative locations that included the writer's workplace and by phone due to the health problems of one informant. The interviews were an average of one hour in duration.

In adherence with Institutional Research Board standards, informants were given a preamble letter emphasizing that participation was voluntary and that the identity of the informant would be kept confidential. After the second interview the preamble letter was modified with the addition of a line that the tape of the interview would be kept secure and destroyed at a later date in lieu of the security concerns of the first informant.

The conduct of the interviews was informed and guided by Dexter's (1970) book Elite and Specialized Interviewing. A general continuity was maintained in the questions

\footnotetext{
${ }^{15}$ A detailed but basic discussion of the Bonacich algorithm and its significance is discussed in detail in Chapter VI.

${ }^{16}$ The Bonacich centrality eigenvalues suggested that 15-20 individuals should be interviewed. The individual centrality scores indicated a central group of 15 individuals with eigenvalues of 25.875 to 19.514. A gradient of 7 points existed where case \#16 had an eigenvalue of 12.755 . Furthermore the two most central cliques contained 12 members and had averages of 16.156 and 15.665 with two individuals redundant to both cliques.
} 
in order to get an idea of the knowledge of different informants and to understand their perspectives.

All the informants were asked questions informed by the growth machine thesis and the subsidiary questions. The question form was mostly open-ended. One sub-set of questions, concerned the overall picture of urban health politics in the metropolitan area, and included:

- The informant's initial perspectives,

- The presence of any primary agenda,

- Identification of "movers and shakers," or key actors,

- The manner in which the movers and shakers conducted transactions,

- The nature of the political atmosphere (polemic versus irenic/peaceful),

- The presence of an ultimate primary opinion leader,

- The role of municipal government and the mayor,

- The effect of board interlocks,

- The tension between cooperation and competition ${ }^{17}$ among healthcare systems,

- The role of Greater Louisville Incorporated,

- The "getCare" network (the local Robert Wood Johnson Communities in Charge demonstration project),

- The role of doctors in the political process.

- The Jewish Hospital Health Services and Caritas Health Services merger

\footnotetext{
${ }^{17}$ The following definitions are offered for purposes of clarity. Competition exists when parties work against each other because the success of one party depends on the failure of the other party. Cooperation is when parties work together because the success of any one party improves the chances of success by the others (Forsyth, 1983, p.484). Collaboration occurs when at least two parties work together to meet both parties' needs mutually and do not compromise on certain goals or values but instead work to maximize the
} 
- The University of Louisville Hospital Management Consortium.

- The closing of Norton Southwest Hospital with the beds relocated to the Norton Brownsboro Hospital under construction.

Some additional questions were added depending on network positions and experience of the different informants.

In order to maintain the privacy and anonymity of the informants, a summative approach was used to compose the chapter on the interview results. This approach also seemed to have the most utility in making the results useful to settings outside Louisville.

\section{An Overview of the Study:}

Chapter II is a primer on the growth machine thesis. It gives a detailed discussion of the thesis and its distinctiveness from other theories. It reviews the relevant research.

Chapter III is a review of the research on local healthcare politics. It is a thorough review of applicable scholarly material.

Chapter IV is a historical analysis of the formation of the Louisville Medical Center from 1945 to 1956 . It reviews how the growth machine was the transcendent force in initiating the planning process and bringing the Medical Center to fruition. It also explores how the growth coalition flexed its muscle to persuade the dissident Methodist-Evangelical group to build its facility in the medical center versus in the Louisville Highlands.

Chapter V is a historical analysis of healthcare politics in Louisville between 1966 and 1983 through examination of the trajectories of the composition and activities of the Louisville Area Health Facilities Council and its successor organizations. This chapter

returns for all parties (Rainey, 2003, pp.345). Coordination will be defined as guiding and synchronizing everyone's behavior (Stone, 1989, p.4). 
explores how the growth machine apparatus started with control and operated in a manner consistent with the growth machine thesis and then squeezed was power by the Federal Government through increasingly restrictive funding regulations. Examination of these trajectories allows for the illumination of the distinction between local control and federal control.

Chapter VI is a review of the salient Social Network Analysis results of a snowball sample of actors in the Metropolitan Louisville, Kentucky area. The snowball sample was derived between 2005 and 2006 from publicly available documents. This chapter discusses centrality and clique analysis findings on individual actors. It discusses centrality findings of organizations. Last, it discusses a network analysis of the community in terms of sectors. The data suggests that growth coalition actors and sectors are central in the community when it comes to local healthcare politics, and it affirms the connection of the growth coalition network with healthcare in Louisville.

Chapter VII builds upon chapter VI in interviews with 22 elite informants. The majority of the informants were individuals who had manifested as being central in the centrality and clique analysis. Other informants who had evidenced as being significant in the network or had been identified as being significant specialists in certain areas by other informants were also approached. The informants were asked various questions to elicit ethnographic type answers about actors, policies, processes, and agendas.

Chapter VIII is a summary chapter that discusses conclusions from the research results. It offers several political strategy suggestions. It also identifies several avenues for further research. 


\section{CHAPTER II}

\section{A PRIMER ON THE GROWTH MACHINE THESIS}

\section{Overview}

The growth machine thesis is a theory that explains the political power structure and nature of local politics in relation to urban development. It has continued to garner attention since its formulation in 1976. In light of this dissertation's purpose, this chapter will give a detailed explanation of the growth machine thesis, discuss its historical background and compare it with competing theories. This chapter will also review the relevant United States research on the growth machine thesis. It will conclude with a critical evaluation of the theory considering its utility for understanding urban health policy and the expected research outcomes.

\section{The Definition of the Growth Machine Thesis}

The growth machine thesis is an "urban political economy" theory that describes how cities are governed. Harvey Molotch initially formulated it in 1976 (and cooperatively revised it with John Logan in 1987). ${ }^{18}$ Molotch (1976) asserted in the growth machine thesis "that the political and economic essence of virtually any given locality in the present American context is growth." Growth unifies local elites in their quest for constant expansion of the city in the areas of population, land development and commerce. For Molotch, growth is the primary motivation for elites to achieve 
consensus and that "this growth imperative is the most important constraint upon available options for local initiative in social and economic reform" (1976, pp.309-310). For those elites who are in a position to make economic gains, the city is a "Growth Machine" and the elites informally come together as a growth coalition $^{19}$ to make political decisions for the city. The general public is only allowed to weigh in when the elites have agreed to disagree on particular issues (Logan and Molotch, 2007, p.51).

\section{The Growth Coalition}

\section{The Members}

Molotch outlined that the growth coalition consists of three categories of local business players who have the most to lose or gain from land-use decision-making (1976, p. 314). The first category consists of parochial/local businessmen (especially property owners) and those in "locally-oriented financial institutions who need local government in their daily money-making routines." The second category of players includes the lawyers, syndicators and realtors who make their incomes and revenues servicing the property owners and investors. The third category consists of parties whose fortunes are tied to the overall growth of a metropolitan area as a whole such as the daily newspaper, universities and local utilities. According to Molotch the growth coalition mobilizes, legitimizes and sustains the sense of local pride and growth momentum into "particular kinds of policy decisions" (1976, pp.314-316).

\footnotetext{
${ }^{18}$ Logan and Molotch also put out a $20^{\text {th }}$ anniversary edition that has a new preface. Otherwise, the chapters of the 2007 edition are the same as the 1987 original edition. All references to the book will be dated 1987 except where specifically noted.

${ }^{19}$ The italics are the author's and not Logan and Molotch's. In later usage Molotch (1990) used the term "growth machine apparatus."
} 
"Local dependence" is a fundamental concept of the growth machine thesis (see Cox and Mair 1988). Molotch's three categories of growth coalition livelihoods all are local business interests embedded in the local area. The growth coalition livelihoods are

Table 2.1

Players of the Growth Coalition

Major Players

Property Investing

Development

Real Estate Financing

Politicians

Local Media

Utilities

Auxiliary Players

Universities

Theaters, Museums, Expositions

Professional Sports

Organized Labor

Self-employed professionals

Small Retailers

(Logan and Molotch, 1987, pp.62-85)

tied to the fortunes of the city and its development; their revenues and profits are related to how much can be earned from the use of the land within the city. The North American city government is also locally dependent on tax revenues it levies within its borders. 
Molotch expanded the growth machine thesis in 1987 in a cooperative effort with John

Logan. The salient feature of the revision is an expanded list of players in Table 2.1.

Whitt (1989) described how the locally-dependent, parochial interests engage in

politics to improve their income and livelihoods through land-use intensification:

The restaurant owner wants more business and a bigger operation; the banker wants to get more deposits and make more loans; the developer wants to tear down the old bowling alley and put up condominiums; the shop keeper wants to see the new urban transportation center located across from her business; the local newspaper publisher wants to have more readers and sell more lines of ads (pp.97-98).

Whitt notes that depending on the proposed growth there can be either conflict or cooperation on land use. For example, local elites may agree on wanting a research park somewhere in the city, but they have conflict about where to put shopping centers or garbage dumps (p.98).

\section{Those Who Are Not Growth Coalition Members}

Logan and Molotch (1987) noted that branch plant managers are absent in local politics (p.85). National or multinational firms with multiple branch plants, back offices and service centers are not locally embedded in any one geographic location and are not usually part of the growth coalition. ${ }^{20}$ Such corporations make revenue from sales of goods or services to multitudes of locations and have easier access to capital to move revenue-making operations. They can go anywhere in their economic interests as produce exportable goods and services. For example a manufacturing facility can be built in any geographical location that serves the firm's maximization of profit within the

\footnotetext{
${ }^{20}$ There is room for exceptions on this point. A case in point is that Boeing's headquarters move from Seattle to Chicago in 2001 suggests that Boeing was not locally dependent on the Seattle economy.
} 
bounds of all applicable governmental regulation. ${ }^{21}$ Therefore the fortune of a national or multinational corporation is not dependent on any one locality and therefore that entity does not get tend to get involved in the politics of any particular locality.

\section{Limits on the Growth Coalition}

The majority of the growth machine thesis is of a descriptive and ethnographic nature recognizing reality's good and bad aspects. Molotch (1988) identified five limits on a growth coalition:

- a location's geographical features,

- the level of unity among civic leaders,

- the patterns of investment by outside corporate capital,

- the skills of local political leaders, and

- urban social movements (p.29).

The geographical features refer to whether a city is on a coast, a river, or is land locked (pp.30-31). The unity level refers to the degree of cohesion among elites in terms of agenda, communication patterns, and ability to work together (p.32). The term "patterns of corporate capital investment" refers the manner by which elites interact within the global economy to maximize development possibilities within the limits of the location's geographical features (i.e., maximizing development of a mostly developed waterfront in cities along rivers (p.35). The "skills of political leaders" refer to the mental schemas of politicians making them mindful that their "bread and butter" is the land-based elite's donations to their campaign coffers. Molotch said, "I would argue that the number one

\footnotetext{
${ }^{21}$ Probably the best examples of this non-local dependence are that many 1) durable consumer goods are made by national and multinational firms in China and Mexico because the cost of transportation is more than offset by the cost of cheaper labor and 2) many food products consumed in the United States are
} 
entrepreneurial skill needed by politicians is the capacity to formulate schemes that benefit growth" (pp.38). Lastly, the elite may face resistance from the non-elite in following through with growth strategies (p.40). Molotch holds that the elites "must manipulate these other forces as best they can and ferret out a way to growth that fits the circumstances" (p.40). With these limits the elite do not always get their way.

Furthermore, some growth coalition economic development schemes fail and make no return on investment. Meyer (1991) concluded that most economic development efforts waste money (p.177). Furthermore, Logan and Molotch (1987) note themselves that the poor or non-elite of the cities can suffer when the growth schemes of a growth coalition fail (p.176).

The Normative and Prescriptive Anti-Growth Component of the Thesis Beyond the negative implications for the non-elite, the last portion of Molotch's original 1976 article is "The Emerging Counter Coalition"22 (pp.326-329). While the most research has focused on the theory's empirical description of the structure and agency of local politics, this last portion converts it into a normative or prescriptive theory. ${ }^{23}$

Molotch stated, "Although growth has been the dominant ideology in most localities in the United States, there has always been a subversive thread of resistance" (p.326). Molotch saw that this counter-coalition consisted of young activists, middleclass professionals and workers who see their tax bills and quality of life in conflict with

produced in the province of Ontario Canada in facilities owned by multinational corporations due to its locational advantage.

${ }^{22}$ This is an exact quote. It is also in the form of an empirical finding despite the normative and prescriptive form.

${ }^{23}$ According to Judge, Stoker and Wolman (1995) "Normative theories concern how the world ought to be; the theorist posits a desired state or set of conditions and argues why it is to be preferred"(p.l). 
growth. Molotch identified an anti-growth coalition in his former hometown of Santa Barbara, California (p.328).

As part of his normative statement, Molotch expressed desire that the growth machine system would die and be replaced by pluralist politics in all localities (p.329). In a more explicit expansion of this anti-growth statement Logan and Molotch (1987) state prescriptively:

Any program of serious reform must wind down the growth machine system through which places (towns, regions, and nations) contort their cultural, physical, and social agendas in order to attract capital. In essence, U.S. cities must stop competing amongst themselves for capital and use their relatively high levels of legal autonomy to compete as a collective force against the growth machine system that has captured them all (p.292).

Logan and Molotch describe a general strategy calling for noblisse oblige of the more affluent localities to start getting tougher with capital. The firm stance of the more affluent localities would then cause a ripple effect of strengthening the bargaining positions of lesser affluent localities. Logan and Molotch theorized that all places will gain and that it is a "trickle-down we can believe in" (p.295).

\section{Historical Background of the Growth Machine Thesis}

Neo-Marxian political economy theory is the inspiration for the growth machine thesis. The growth machine thesis then is about both the pursuit of maximized revenues from land use within a city as well as the local political activity by the growth coalition members to make their fortunes.

The growth machine thesis, together with "regime theory," marked resurgence in the study of community power (or who really governs our communities?). The two theories constitute the bulk of the "urban political economy" perspective. Vogel (1992)

\footnotetext{
"Prescriptive theories are instrumental; they are concerned with the best means of achieving a desired
} 
concluded that Stone's and Molotch's theories "could account for divergent pluralist and elite findings" (p.13).

\section{The Stalemate in Community Power Studies}

Waste (1986) noted that for the better part of two decades (1961-1981) efforts to refine community power studies stalled. He noted that pluralists and elitists were at a stand-still due to their rigid adherence to their research methods (pp.13-25). Vogel stated that "Theory building was precluded because scholars were unable or unwilling to have a dialogue" (p.12).

\section{The Urban Political Economy Genesis}

Waste found four movements in the 1970's that led to a "détente" in community power research. First there was a fresh look at quasi-Marxian insights. Second, there were some "innovative attempts" in rethinking some of the theoretical problems in urban studies and community power. Third, there were attempts to re-conceptualize research methods appropriate to answer the questions of community power. Fourth, a peaceful milieu occurred among community power researchers. Waste noted that in the midst of these movements Stone combined decisional and positional research methodologies to arrive at his regime theory of community power, and that Molotch was representative of the synthesis of Marxian insights (pp.20-21). Vogel asserts that the urban political economy perspective evolved from the community power perspective and does not replace it (p.14).

condition" (p.2). Empirical theory is based on observation or results of hypothesis testing (p.2) 
How the Growth Machine Thesis Differs from other Theories ${ }^{24}$

The growth machine thesis competes with five other theories of urban politics. ${ }^{25}$

This section will compare the growth machine thesis with elitism, pluralism, Marxism;

Peterson's City limits limited view of city politics, and regime theory. Elitism and

pluralism were competing theories in the community power structure school of the

1950's and 1960's. Marxist theories of urban politics were formulated in the early

1970 's. The growth machine thesis and regime theory arose out of the urban political

economy movement were formulated in the late 1970's. Peterson wrote about the limited

view of city politics in 1981 . This section will compare the growth machine thesis and the above mentioned theories with special attention given to regime theory.

\section{Elitist School}

The elitist school of community power holds that even with democratically elected government, the power in a city is largely held by a few elites from business interests, as well as senior political, bureaucratic interests (Dowding, 1996, p. ix). The starting point of the elitist view is the reputational or positional research approach focusing on 1) perceptions of who is in power and 2) people sitting in places of power (Harding, 1995, p.39). Hunter (1953) was the leading proponent of this view. He argued that in the late 1940's Atlanta was run by a cohesive set of business leaders who dominated decision-making for the city and that elections were manipulated by the elite for their purposes.

\footnotetext{
${ }^{24}$ These theories do not account for healthcare in the city as Lennarson-Greer has noted that urban studies scholars have not studied healthcare. What could be said about healthcare is going to be a logical extrapolation by the writer.

${ }^{25}$ There are more theories, but these five schools of thought have garnered the most attention. Furthermore, whether the growth machine really competes is a matter of perspective.
} 
Elitist theory and the growth machine thesis agree about elite actors as decision makers but the growth machine thesis goes farther in explanation. Harding considers the growth machine thesis to be a refinement of elitism, but it focuses on urban development and not just the factors affecting local government decisions. Harding observes that Logan and Molotch emphasize the role of individuals and interest groups as opposed to rigid focus on structure (p.42). The growth machine signifies how elites function (Logan and Molotch, 2007, p.ix) whereas the elitist school stops at identifying the power structure and cannot account for policy outputs.

\section{Pluralist School}

The pluralist school of urban politics is a reaction or response to the elitist school. ${ }^{26}$ Dahl (1961) studied a number of local political processes in New Haven, Connecticut and argued that local governance was pluralistic and not elitist. His difficulty with the elitist view was that it left little room for the existence of the elected politician (p.6). He argued that the mass and the leaders govern together (p.7). Dahl's "decisional" method of study was different from Hunter's in that he looked at various decisions that had been made in New Haven and created an incidence matrix (or basically several comparative lists) of who all had been involved in the decision-making. He had determined that a pluralistic set of multiple parties had been involved in decisions for New Haven during his time of observation.

Pluralism has several variants based on the level of perceived inclusion or exclusion. Classic pluralism is the most inclusive of this continuum as it views public policy to be a tug of war in an open and free process. Hyperpluralism sees government containing multiple interest groups and that government is weaker than the pressure 
group segment. Stratified pluralism ${ }^{27}$ sees political actors divided into two strata-the inactives and the actives and that membership of a stratum changes depending on the issue. Privatized pluralism is the least inclusive or most exclusive that views politics is usurped by a limited number of participants (Waste, 1986, pp.121-128). Jordan (1990) concludes that the divergent pluralist views all advocate that power is desirably fragmented and decentralized and the policy outcomes will reflect different processes (p.293).

The growth machine thesis may initially sound like privatized pluralism, but it is clearly different from pluralism. Logan and Molotch (2007) note that power is held by the elite and the general public only gets to take part in decisions if the elite have agreed to disagree (p.51).

\section{Marxist Theory}

Like pluralism, Pickvance (1995) notes that there are variants of Marxist urban theories, but they all share the perspective that local political institutions are part of the "state apparatus, and hence inescapably marked by the role which the state plays in capitalist society." In the Marxist framework capitalism depends on the state to play two "indispensable" roles of provision of the prerequisites of production ${ }^{28}$ and maintenance of the social $\operatorname{order}^{29}$ (p.253).

There are two pertinent variants of Marxist urban theory: instrumentalism and structuralism. For the instrumentalist, the state is an instrument of the nationally

\footnotetext{
${ }^{26}$ According to Waste (1986) classic pluralist thinking goes back to Madison and Tocqueville

${ }^{27}$ Stratified pluralism is the particular view that Dahl adhered to.

${ }^{28}$ The perquisites of the production system according to Pickvance are a legal system, a monetary system, a communication system and transportation system to a healthy labor force with the skills and motivation needed by employers ( $\mathrm{p} .253$ )
} 
dominant upper class, and thus urban politics are moot because the policy comes from external forces. The structuralist view sees the state as having some autonomy in performing accumulation and legitimation functions and so urban political institutions have autonomy to create social order by reconciling national and local class interests. Specific theories of urban politics are related to instrumentalism or structuralism and the class struggle (Pickvance, p.254).

While Logan and Molotch (2007) credit the Marxist perspective in influencing their thinking, they clearly eschew the Marxian "frame" as being "brittle in its determinism." Their critique of Marxism is that it is generalizes in characterizing the actors (capitalists and not any particular groups). They also saw that "There wasn't much room for human agency and the kinds of empirical variations that people produce as they strive to make their lives and fortunes out of place" ( $p$. viii).

\section{Peterson's City Limits}

Peterson (1981) believed that the pluralist, elitist, and political economy views are correct to a degree and "give a quite convincing portrait of the local political landscape." However Peterson saw that the cumulative error of the three perspectives was that they viewed local politics in the same terms of "nation-states" and that cities had few if any limits (p.5).

In response, Peterson said that one "explains urban public policy by looking at the place of the city in the larger socioeconomic and political context." For Peterson the larger, national political economic context in which the city is embedded "fundamentally affects the policy choices that cities make." In making a limited number of choices,

\footnotetext{
${ }^{29}$ Pickvance states that the state maintains social order through 1.) creating of institutions to contain social conflict, 2.) diffusing supportive images and attitudes, 3 .) introducing policies containing 'concessions' to
} 
cities are going to make those decisions in the city's interest. What is most controversial about Peterson's view is the following statement "It is these city interests, not the internal struggles for power within cities that limit city policies and condition what local governments can do" (p.4). For Peterson, the city is automatically going to act in developmental ways that enhance or maintain the city's economic position, prestige, or political power (p.20). Peterson's theory is thus viewed as having taken the politics out of local politics. ${ }^{30}$

Logan and Molotch do not come out and directly oppose Peterson in either edition of Urban Fortunes. Nevertheless, Vogel (1992) concludes that Logan and Molotch and Peterson are not so different in their explanation of the actual workings of the political economy, but they "believe that it is possible for local citizens to alter the local political economy to achieve more "social justice"" (p.20). ${ }^{31}$

Regime Theory

Regime theory like the growth machine thesis arises from urban political economy and regime theorists also are critical of Peterson's theory to negate politics (Stoker, 1995, p.56). According to Stone (1989) a regime is the "informal arrangements by which public and private interests function together in order to make and carry out governing decisions" (p.6). Lauria (1997) proclaims that regime theory has "gained the dominant position in the literature on local politics precisely because it dispenses with the stalled debates" between the various theoretical dualisms (p. 1). ${ }^{32}$

subordinate classes, and 4.) creating of repressive institutions (p.253)

${ }^{30}$ Imbroscio (2003) noted that urban scholars were "irked" by this statement (p.272)

${ }^{31}$ Vogel is referring to the aforementioned normative and prescriptive portion of the growth machine thesis.

${ }^{32}$ Full quote: "Urban regime theory appears to have gained the dominant position in the literature on local politics precisely because it dispenses with the stalled debates between elite hegemony and pluralist interest group politics, between economic determinism and political machination and between external or structural determinants and local or social construction" (p.l). 
Like pluralism, regime theory holds that no one group is likely to have comprehensive control and so governance of a city is achieved by sustained, informal cooperation among the pertinent parties (Stoker, p.57-62). However, there are a number of differences from pluralism in that regime theory sees a dependence upon private actors and economic factors whereas pluralism does not (Stone, 1993, pp-10-17). Stoker argues that for the regime, politics is about production while achieving and maintaining a governing capacity through long-running partnerships versus taking matters issue by issue (as pluralism does). Regime theory values electoral politics, but recognizes the tension between popular control gained through general elections and elite ability to dominate in local policy making (pp.59-60).

With this political and economic tension in mind, there are numerous types of regimes that can be formed. Stone (1993) has identified a number of different regimes that are characterized by the regularly produced policy:

- maintenance,

- development,

- "middle class progressive"

- regimes devoted to a lower class opportunity (pp.18-20). ${ }^{33}$

Savitch and Kantor (2002) identified seven other regime types that arise out of indigenous social conditions, local political traditions, and the national structure in which

\footnotetext{
${ }^{33}$ The maintenance regime centers on service provision and makes no effort to introduce change. The development regime is concerned with changing land use in order to reverse decline or promote growth. The middle-class regime focuses on quality of life. The regime dedicated to lower class opportunity focuses on human capital (job training and education) and transportation infrastructure (Stone, 1993, pp.1820).
} 
a city is embedded. ${ }^{34}$ Regime theory makes allowance for various arrangements of social, political and economic variables.

The growth machine thesis shares much with regime theory under the umbrella of the tenets of urban political economy as outlined by Vogel. Communities are driven by the urban development process that occurs as a product of the interplay between economic logic and political logic. The local community is governed by coalitions of political and economic actors responding to both political and economic forces.

Localities depend on business but have limited power within the structure of higher levels of government, and so economic development is the dominant issue on the local agenda. Lastly, a locality is not impotent but has some bargaining power with higher levels of government and with business as business has sunk costs that make facilities not easily moveable (pp.15-20). The essence of the tenets is a combination of agency (human action) and structure around economic development as a prime local agenda.

The difference between the two theories is at best described as one of focus. Where does one focus on the political-economic continuum? Is it more agency (or human activity)? Or is it more (political) structure? In this case the growth machine thesis focuses on a specific list of dominant actors and their agenda while the other focuses on the institutional arrangements. ${ }^{35}$ In their $20^{\text {th }}$ anniversary of Urban Fortunes Logan and Molotch note that Stone "held off on a conclusion as to who substantively runs things" (p.ix), and recognize that Stone identified four types of regimes (Stone,

\footnotetext{
${ }^{34}$ Savitch and Kantor's seven regime types are: vendor, free enterprise, mercantile, grantsman, clientelist, planner II, and planner I (p.304).

${ }^{35}$ Harding (1999) gives an excellent discussion of the dichotomy (pp.677-678).
} 
1989, p.187). ${ }^{36}$ On the other hand, Logan and Molotch use the term "growth machine to signal our conception of just who is dominant and how they function"(p. ix). ${ }^{37} 38$

\section{A Survey of the Relevant Research on the Growth Machine Thesis}

The growth machine thesis has been the focus of a vast number of research studies over the past 32 years. Scholars of various disciplines (Geography, Sociology, Urban Studies, Political Science, Economics, and Anthropology) have conducted analysis by different research methods, for different purposes, from different angles, and at different levels of sophistication or abstraction. Jonas and Wilson (1999) proclaim that the growth machine thesis has "stood the test of time" (p.3).

Complexity versus Cacophony

In reviewing the prior research on the growth machine thesis, there has been no traditional, consistent standard recitation of validating studies about it that build upon one another. ${ }^{39}$ In other words, there has been no prior comprehensive survey of the research on this theory. In reality, even the aforementioned Jonas and Wilson collection does not have a comprehensive survey of the research. The practice of previous researchers is to only cite Molotch or Logan and Molotch and at best a few other authors before proceeding with discussion of their specific study. ${ }^{40}$

What was hoped for was a body of orderly constructed studies that were clearly building upon one another in terms of a paradigm versus the scattered and disjointed

\footnotetext{
36 The types of regimes are: "free-spending distributors of patronage to the penurious, from mobilizers of the immigrant masses to defenders of the small property holder, from caretakers to activist remakers of the urban landscape" (p.187).

37 The italics are Logan and Molotch's.

${ }^{38}$ It must be included that a primary ability of the politicians in the growth coalition is that of negotiating with the next higher level of government. (Logan and Molotch 2007, p.69).

${ }^{39}$ The research has been more in terms of affirming urban political economy tenets.

${ }^{40}$ Even the dissertation Allain (1998) supervised by Molotch available on the Digital Dissertations database did not go into a comprehensive survey of the research and it was 1002 pages in length.
} 
reality. There was an expectation along the line of Kuhn's (1962) The structure of scientific revolutions that the existing research was going to adhere closely to the paradigm and then look for anomalies. This was not the case as the pattern of scientific discovery suggested by Kuhn was not the reality discovered in the studies supporting or examining the growth machine thesis. There were a number of philosophical treatises on the growth machine thesis that are of little practical use for the purposes of this survey. Some research that came up in Internet queries and database queries was not focused on testing the growth machine thesis as the central matter to be proved or disproved, but the clear-cut research question was often another matter for other intents. Another problem is the generic nature of the term "pro-growth coalition." In a significant number of studies the term "pro-growth coalition" $" 41$ was used generically in an urban political economy sense and Logan and Molotch were not referenced or cited. Logan, Whaley and Crowder $(1997,1999)$ in their article "The Character and Consequences of Growth Regimes: An assessment of Twenty Years of Research,"1) gave very little survey of prior research on the growth machine thesis, 2) validated that growth is the most pressing issue of local politics, and 3) that the alignment of local political power continues to follow Molotch's 1976 original proposition (pp.73-93). ${ }^{42}$ The dearth of a prior comprehensive survey appears in part to be a product of the aforementioned complexity of the corpus of previous research on this theory and what probably is a lack of interest the recitation of prior research studies. In light of the state

\footnotetext{
${ }^{41}$ Mollenkopf (1983) used the term "pro-growth coalition" early in the research. A concrete example of this term usage without citing Molotch or even Mollenkopf is Brautigam, Rakner and Taylor (2002) on their study of business involvement in "growth coalitions" in Sub-Saharan Africa.

${ }^{42}$ These are the page numbers in the Jonas/Wilson book and not the 1997 article version

${ }^{43}$ The generic use of the term "growth coalition" could be looked at in a number of lights. The generic acceptance could add validity to the growth machine thesis because it is an accepted concept across the
} 
of the research, this dissertation's aim is to be useful to a wider audience. Therefore, this survey will selectively focus on identifying research that specifically tested for the presence of the growth machine apparatus in the United States (verification of structure and activity) and whether the growth machine thesis is/was valid in terms of suggested outcomes.

\section{United States Studies}

There are both quantitative and qualitative studies on the application of the growth machine thesis in the United States, but most studies are qualitative. The relatively few quantitative studies are regression analysis and factor analysis testing subsidiary aspects such as the expected outcomes of population and tax increases.

The quantitative studies aimed at testing the growth machine thesis tended to be among the earliest. These studies used existing data sets to determine whether there was population growth and tax increases. Krannich (1980) conducted structural equation procedures on 92 Pennsylvania "minor civil divisions." 44 Krannich and Humphrey (1981) found in their survey that most communities in the sample had a growth machine apparatus but inconsistent success (p.73). ${ }^{45}$ Lyon et al (1981) using factor analysis on 1971 statistics of 51 cities supported some of the growth machine thesis' major tenets. ${ }^{46}$

board in urban political economy, or it could be looked at as a discounting of it. The spirit of many of the articles with generic usage indicated an authorial intent to be as broad as possible.

${ }^{44} \mathrm{Krannich}$ appeared to have operationalized the growth machine as power centralization and collective action to promote business and industrial growth. He also considered accessibility of the community, prior rates of population change, size of place, and aggregate socioeconomic status of the local population. $\mathrm{He}$ found that the growth machine did not always succeed, but he did not disprove the thesis (Abstract from ProQuest Digital Dissertations).

${ }^{45}$ Krannich and Humphrey operationalized the growth machine through a variable of the number of residents in managerial and administrative occupations, employment in growth industries, growth of local population, and socioeconomic status of the community and population growth rate for the previous five years before frame of observation (pp.64-65).

${ }^{46}$ Lyon et al. operationalized the growth machine by a number of variables but it appears that business power perception was the key operationalization. They determined one rejected hypothesis to be that there would be increased taxes, but determined that there was support of elite manipulation of events. 
Kelly (1983) conducted survey research of 300 mayors of county seats in the northeastern United States. ${ }^{47}$ McGranahan (1984) combined interview research with census data in regression analysis in rural Wisconsin. ${ }^{48}$ Allen (1988) conducted regression and correlation analysis using the 51 communities on the National Opinion Research Center "Permanent Community Sample" from 1982-1983. ${ }^{49}$ Hill and Durand (1988) validated the overall proposition of the three groups Molotch identified in the 1976 version of the thesis of elite players valuing growth while finding that elites have different conceptions of what growth is (p744) ${ }^{50}$. Clingmayer and Feiock (1990) combined survey results with other data in logit regression analysis supporting the existence of growth coalitions with benefits going "to a rather select set of beneficiaries" (p.549) ${ }^{51}$ Logan and Crowder (2002) conducted research much like Lyon (1981) and found that pro-growth coalitions were influential but there was inconsistent success. ${ }^{52} 53$ These quantitative studies were at best supportive of the growth machine thesis.

\footnotetext{
${ }^{47}$ Kelly found that the issue orientation of the mayors in the sample supported the "conceptualization of the city as a growth machine." Her operationalization appeared to be merely that the mayor is part of the growth machine and results would be commensurate with that. (Abstract from Proquest Digital Dissertations)

${ }^{48}$ McGranahan operationalized the growth machine as elites having connection to the next highest level of government. He using multiple regression, he regressed population data from 1970 and 1980 on an ordinal scale he created to determine that the influential individuals who had greater ties to the next higher level of government. The more a community had elites involved with external ties, the higher the tendency was for community population growth.

${ }^{49}$ Using existing data Allen found that the growth machine thesis was supported in that the cities undergoing rapid economic growth had greater support of business. Her interpretation of the growth machine thesis included that rapid population group would result. Her operationalization included variables depicting the importance of business support in terms of reputation, and population growth. (Abstract from Proquest Digital Dissertations)

${ }^{50}$ Hill and Durand merely operationalized the growth machine as elites as determined by reputational and positional analysis. They included business interests, elective and appointed officials, and executives of corporations that had branch plants in the specific region studied.

${ }^{51}$ Clingermayer and Feiock operationalized growth machines as responses to four questions on their survey pertaining to the activity level of civic and business organizations, whether an over-arching/elite organization existed in the community, activity of neighborhood organizations, and the level of support media lent to developmental efforts (p.544).

${ }^{52}$ Logan and Crowder used a survey research design asking precise questions about who were the most involved actors in local politics. Their operationalization of the growth machine was an alliance of
} 
It is questionable whether these quantitative studies actually prove or disprove the explanatory power of the growth machine thesis as an accurate description of local politics? It appears that there are two ways to interpret Molotch's statements: in prescriptive and normative terms or in empirical terms (it is the observed result). If the prior researchers were taking a normative reading that taxes and population should increase if growth efforts are successful $(1976$, p.310) then they probably did not generate valid results that proved or disproved the growth machine thesis. In light of that consideration Kulcsar and Domokos make a valid statement:

The main finding of the empirical tests was that the growth machine is obviously not working similarly in every place and is therefore contingent on the local socio-economic context" (p.550).

However, a number of other quantitative researchers took a different vein following the normative and prescriptive portion of the growth machine thesis in showing what it took to undermine the growth machines. ${ }^{54}$ Schneider's (1992) study of 700 communities using multiple regression models showed that the effectiveness of growth machines slowed down and was causing a rise in coalitions opposed to growth. His study with Teske (1993) included surveying suburban city clerks to identify what factors existed for the conditions that led to anti-growth coalitions. ${ }^{55}$ Humphrey ${ }^{56}$ used

interests around a core of "land owners, builders and real estate developers" focused on intensification of land use (p.114).

${ }_{53}$ In the abstract Logan and Crowder wrote "However, there is no evidence that either growth policy or the type of political regime significantly influences changes in population size, racial composition, or median income of these suburbs. These results cast doubt on the assumed efficacy of local growth policies and raise additional questions, regarding the impacts of extra-local factors in the development of suburban municipalities" (p.113). This is recognized by Kulcsar and Domokos (2005) as not supporting the thesis. ${ }^{54}$ Qualitative studies on this same topic include Vogel and Swanson (1989).

${ }^{55}$ They received a response of 963 out of 1400 mailed surveys. They concluded that "anti-growth entrepreneurs appear when there are rewards to be gained such as a full-time mayor position, or there is a high degree of popular control (neighborhood groups and district elections).

${ }^{56}$ Humphrey cites Feiock (1991) as a previous model for his study on the growth machine thesis, but Feiock's study makes no mention of the terms "growth machine," "growth coalition," and does not cite Molotch. 
regression analysis on a sample of 96 small urban areas supporting the relevancy of the growth machine thesis in those areas. ${ }^{57}$ While these quantitative studies did not aim to assess the validity of the growth machine thesis, they showed political conditions where growth machine apparatuses were hampered—including places with higher socioeconomic populations, higher levels of popular control and ward-elections versus atlarge elections (in other words conditions that enhanced popular control/democracy).

There were far more qualitative studies in the form of case studies supporting the presence of growth machine apparatuses in U.S. localities. A case study design allows for greater detail in exploration and accounting for processes over time. A growth machine apparatus cannot necessarily be looked at in a purely static fashion, but must be studied over time as to its actions and methods of operation. It is noted here that a number of the localities were studied more than one time. Table 2.2 lists those major U.S. localities where case studies established the presence of a growth machine apparatus as an explanation of the political situations in those localities. However, there was not continuity per se in the intents of the case studies. For example Whitt (1988) examined growth coalition activities through arts development in Louisville. Savitch and Vogel (2004) demonstrated how the growth coalition was instrumental in successfully campaigning for referendum for the city-county consolidation of Louisville and Jefferson County, Kentucky. These two case studies that affirmed the existence of a growth machine apparatus were done on the same city, but for different reasons.

Other case studies demonstrate a presence of apparatuses. One example is Jonas (1991) who argued that there were multiple (and not just one) growth coalitions in the

\footnotetext{
${ }^{57}$ Growth machines were intensifying land use, and there was a stratification of places where more affluent areas were more selective as to what kind of growth they pursued.
} 
Table 2.2

Larger US localities where case studies demonstrated a growth machine apparatus. ${ }^{58}$

Locality Author(s)

Houston, Texas

Feagin (1985), Schaffer (1989)

Louisville, Kentucky Whitt (1988)/Savitch \&Vogel (2004)/Savitch et al $(2008)^{59}$

Chicago

Ludgin (1988), Mayfield (1996)

Boston

Ludgin (1988),

San Francisco

Ludgin (1988)

Denver

Ludgin (1988)

Atlanta

White (1996), ${ }^{60}$ Goodman (2000)

Lexington, Kentucky

Fendley (1990)

Columbus, Ohio

Jonas (1991)

San Diego.

Calavita (1992)

Portland, Oregon

Goodman (2000)

New Orleans

Goodman (2000)

Minneapolis

Goodman (2000)

Orlando

Thomson (1995)

Hilton Head South Carolina

Martin (1996)

Fort Wayne, Indiana

Rosentraub and Helmke (1996)

58 Here are some other case studies in smaller communities or regions. Box (1990) demonstrated the presence of the growth machine apparatus in Midland and Ashland Oregon. Timmons (1993) demonstrated the presence of an apparatus in Orange County, California. Sackman (1997) demonstrated a growth machine regionally in Southern California. Hainze (1998) examined the growth machine apparatuses in Albuquerque NM, El Paso TX, Amarillo TX, Lubbock TX. Killmer (2001) identified an apparatus in Woodbridge County, NJ, and Jepson (2004) reviewed the apparatus in Cortez, Florida. Foreman (2003) reviewed the growth coalition apparatus in both Dade and Hillborough Counties in Florida. Paradis (2002) studied the growth machine in Roswell, New Mexico. Peterson (2000) determined that there was not a growth machine apparatus in the eastern "Upper Peninsula" of Michigan.

${ }^{59}$ The article authors are Savitch, Tsukamoto, and Vogel.

${ }^{60}$ White's study is about an Asian community as a growth coalition. It is not about the whole of the Atlanta metropolitan area. 
Columbus, Ohio area from 1954 to 1980 . In their study of Fort Wayne, Indiana

Rosentraub and Helmke (1996) argued for a dichotomy between a growth coalition and a regime where growth coalitions rose and fell and even evolved into more stable regimes in that city through the observed time frame of about 70 years. ${ }^{61}$

In another vein, Calavita (1992) supported the growth machine apparatus existing in San Diego but was more focused about the imperative of using a longitudinal method for research given what he found in that locality. Again, these case studies are examples that there has not been a consistent research agenda with a particular, orderly paradigm that has been contributed to by scholars regarding the validity of the growth machine thesis in the United States. ${ }^{62}$

${ }^{61}$ This appears to relate to Logan and Molotch's (2007) statement cited earlier that the growth machine apparatus can lead to the formation of more stable regimes ( $p$.xi).

${ }_{62}$ The following were identified, published case studies on the growth machine thesis on international venues. Not all studies found the presence of a growth machine apparatus.

There were four case studies on Canadian venues. These were Lewis (1993)--Montreal from 1850 to 1918, Gilliland (2002)--1918 and 1946, Allain (1999) New Brunswick from 1960-1998, Reese and Rosenfeld (2002)-several Ontario venues.

There were multiple venues in the United Kingdom identified as having growth coalitions that had formed as a product of Thatcherism and/or the Thatcher government coming to power and dismantling socialistic national structure. Harding (1991) identified growth machine apparatuses in Multiple United Kingdom venues including Birmingham, Victoria, Hull, Newcastle, St. Helens, Wearside, Glasgow, Victoria, and Leeds (pp.306-307). Thornley and Newman (1996) also said that Birmingham has a growth machine apparatus. Bassett and Harloe (1990) identified that a growth machine apparatus several decades before the Thatcher government had come to power in Swindon, but it fell apart with Labour Party national policies.

The following were pertinent European case studies. Thornley and Newman (1996) confirmed a growth machine apparatus in Malmo, Sweden. Tenhorst and Van De Ven (1995) argued for a national "urban growth coalition" existing in The Netherlands. Kulcsar and Domokos (2005) noted the formation of a version of the growth machine apparatus in Hungary. Molotch and Vicari (1988) repudiated the presence of a growth machine apparatus in their study on Milan. Strom (1996) was unable to identify a growth machine apparatus in reunified Berlin, Germany (p.470-471) (Strom's findings were echoed by Cochrane and Jonas (1999).)

There were two studies in Israel. Kirby and Abu-Rass (1999) do not invalidate the growth machine thesis, but argue that it misses the state's role (pp.224-225) while Razin (1998) found some American-type growth coalitions present in Israel (p.442).

Notable Asian studies were as follows. Broadbent (1988) argued for the existence of a type of growth coalition in the Oita prefecture of Japan at a larger level than the local level. Smart and Lin (2004) identified that growth coalitions in Hong Kong and the Mainland China border district. He and Wu (2005) and $\mathrm{He}(2006)$ identified a nationally-dependent growth coalition in existence in Shanghai. Bae and Sellers (2007) found temporary a growth coalition in the booming Koyang, South Korea that succumbed to a growth management movement of affluent middle class residents. Qian (2007) identified a regional, 


\section{Section Summary}

This section was a survey of the research on the growth machine thesis on United States venues. There were some quantitative studies that demonstrated that the theory was contextually based in the U.S. and not equally applicable. There were a sizeable number of qualitative case studies that through intense study of localities demonstrated the presence of growth machine apparatuses. In Canada, the three applicable studies all affirmed the historical activity of growth machine apparatuses in Montreal and New Brunswick. The studies outside of North America found some growth-machine-like apparatuses but the theory was of limited use due to the governmental systems and the different policy and fiscal constraints national governments have on localities.

Critical evaluation of the growth machine thesis

This section will critique of the growth machine thesis. It appears that the primary strength of the growth machine thesis is also its primary weakness: a specific conclusion that local land-based elite focus on local growth is the essence of local politics in the American context. Secondly, with time other researchers have noted other areas of where the growth machine thesis misses nuances in specific local contexts both in the United States and other countries. However, the explanatory power of the growth machine thesis continues to be robust because of its specificity about agency or political

\footnotetext{
government-led growth coalition (that included private interest involvement in the "Hangzhou High Technology Zone." One of the important themes in the Asian studies (especially in the Chinese studies) is the rise in market economics and the intensification of land use for market purposes.

There were two relevant African-based studies. Brautigam, Rakner and Taylor (2002) note that public-private growth coalitions existed but were rare in Mauritius, Zambia, Zimbabwe. Moffat and Freund (2004) noted public-private interaction in Durban, South Africa but did not commit to identifying a community power structure.

There was one South American study. Warner and Negrete (2005) identified that no growth machine apparatus existed in Chile (p.591).
} 
activity in the reality of the American context: American localities must act in similar ways due to being embedded in the same American federalist system.

\section{Weaknesses}

Within the urban political economy school of thought, the scholars who have eschewed the growth machine thesis as being too narrow had their focus on the broader institutional aspect of local politics. Regime theory does have an advantage as its formulation accounts for broader set of institutional arrangements emanating different types of agency or activity across domestic and international contexts than the growth machine thesis. Different communities have elites with different kinds of interests and agendas and not all localities are interested in the same type of growth. ${ }^{63}$ Not all elites have the same kind of power and options available to them based on the larger structure which the cities reside. Elites may align themselves in different organizational configurations across cities which by the nature of those configurations creates different political outcomes. Regime theory can accommodate more variations due to its inclusiveness for different types of structures.

Lloyd and Newlands (1988) noted a number of criticisms of the growth machine thesis along the lines of institutional arrangements. First, they felt that it was not evident that local business interests will always be a growth coalition's leading group or core. Second, they felt that Molotch "overstates" the differences in interest between local business interests and national or multi-national in local politics. Third, they felt that Molotch poorly formulated the theory in that he did not explain the process by which

\footnotetext{
${ }^{63}$ This could be harmonized with the concept of stratification of places where localities with higher levels of socioeconomic status can be more selective than lower socioeconomic status of the kinds of growth chosen. Peterson's (2000) study "Upper Peninsula" of Michigan also could be expanded on as to nuances--though the region overall did not have a growth machine mentality, pockets within it may have.
} 
local government is "co-opted" by business interests into the growth coalition (pp.34-35). If one is looking at institutional or structural explanations of local politics as a key standard of validity, these criticisms make sense.

Another set of criticisms come with the exploration of various nuances that broaden perspectives. Gilbert (1999), in her chapter in the Jonas and Wilson book gives a feminist critique of the growth machine thesis. Her complaint is that Logan and Molotch failed to look at power relations as they pertain to the oppression of women and the role of women in the creation of places which leads to "a romanticization of community and an impoverished notion of the politics of place" (pp. 95-108). It is proposed that a gay and lesbian critique from along the line of Gilbert's critique could likewise be made about the growth machine thesis, and that will depend upon how much further Florida's (2002) creative class theory is expounded on in future research and if there is interest. ${ }^{64}$ While Gilbert's critique of the growth machine thesis is interesting, there was no evident research thread building on her suggestions.

What is probably more practical in terms of criticism based on nuances is encompassing that not all elites due to benefit from growth in a city are going to seek land use intensification. Growth in a city can mean improving human capital and community stability (Imbroscio 2003, pp.276-277). A locality is not going to grow in the global economy of the $21^{\text {st }}$ century unless it has the profile to attract high-tech and knowledge-based jobs.

One last set of criticisms pertains to the anti-growth portion of the thesis. Outside the matter of whether or not anti-growth coalitions can sustain positions of power and 
dominance in local communities (Vogel and Swanson, 1989, pp.81-82) this portion has not been assessed in the majority of the research—especially the international studies. While the utopian ideal of cities being able to negotiate with business on an egalitarian basis or from an advantaged bargaining position sounds attractive, it like many other theories, is rather idealistic and vague and very unlikely to happen in a world where disjointed incrementalism is the political norm and not the exception.

\section{Responses to Weaknesses}

When looking at the various criticisms, it seems that a proverbial grain of salt must be taken. Walton (2000) noted in his review of the Jonas and Wilson volume that with the consideration of any social science theory there will always be hindsight and a theory's flaws will always be put under a microscope. Walton wrote in response to the various criticisms of the growth machine thesis:

Contributions to the legacy of social science should be measured in the context of their time rather than by later standards that owe their achieved sophistication in some part to the early work. By that measure, the growth machine fares better than recent schemes that would replace it (pp.241).

A second response to the criticisms of Lloyd and Newlands (which had much in common with Harding's [1991] comment) about the lack of problems relating to crossnational contexts is that Molotch did not initially formulate the theory for international purposes. Molotch formulated the theory to be for the American context. While there are numerous repetitions of the same criticism that the growth machine thesis only translates in part to international contexts undergoing globalization and market reform

\footnotetext{
${ }^{64}$ One of Florida's variables in his creative class index is tolerance as operationalized by tolerance as it pertains to the number of gays and lesbians in a city. Any measure accounting for oppressed people groups could probably be studied in this same light.
} 
due to governmental system structures, its saving grace seems to be the agency (or human activity) portion of the theory.

A third response to Lloyd and Newlands pertains to agency. Agency is actually unpredictable in and of itself. This is when desiring identification of a process by which business interests co-opt government for development purposes. While interactions of elites pursuing growth occur within the structures of community institutions, the interactions by nature are resistant to being organized in taxonomy and can be tolerated as generalities or vagaries and labeling them "agency."

The human activity or agency aspect of local politics does not happen through any one particular institutional structure and can engender imprecision as a potential downfall. In urban studies there are extremes of Peterson's (1981) economic determinism and regime theory's neglect of economics (Imbroscio, 2003). The growth machine thesis inclusion of agency or human action provides an important conceptual middle ground for studying the political actors in power and their interactions within a city and making sense of their agendas that wind up shaping the local landscape This is important as institutional arrangements vary from locality to locality.

\section{Strengths}

Weaknesses aside, the primary strength of the growth machine thesis is its specificity on economic growth. Warner and Negrete (2005) said,

Urban growth machine theory has the advantage of directing our attention to the underpinnings of policy agendas and the recurrent conflict between the use values versus the exchange values of places (p.573).

Warner and Negrete felt that the growth machine thesis provided a "useful starting point for identifying important dimensions of variation" (p.574). While Logan and Molotch's 
inclusion of economic motivation and identification of locally dependent actors (or sectors) are delimiting, they allow for more meaningful research as to different policy areas within a city—especially in the politics of production and development.

With the growth machine thesis, it is possible to ask more precisely, the different interrogative questions: Who are the actors? What are their decisions? What are their agendas? What are the outcomes of their decisions? As evidenced by the survey of the research on the growth machine thesis, there were both quantitative and qualitative designs which sought to answer the different questions.

Furthermore, the growth machine thesis allows for explanation of different types of local politics within the city itself beyond the mere existence of institutional structures. Regime theory can make generalizations about a city's governance pattern as a whole, but its endeavor to be inclusive of the governance structures of the locality as a whole limits its interpretation to structure. The growth machine thesis inclusion of agency makes allowance for exploring the different types of conflict and cooperation by which there is a tension of political and economic logic.

\section{Chapter Summary}

The chapter sought to provide a primer on the growth machine thesis. It sought to acquaint the reader with the theory, its under-pinning, its history, and its research.

The growth machine thesis holds that growth is the essence of local politics. Locally-based elites who are dependent on making their incomes and livelihoods from development of the land within the locality tend to cooperate in a "growth coalition" to make political decisions for the community. These decisions are usually about land-use intensification that will benefit the interests of the elites. Only when elites agree to 
disagree on issues, does the general public get involved in decision-making. Logan and Molotch recognize that the non-elite suffer consequences for the failed growth schemes of the elite. They also call for a preferred state of localities uniting against the growth machine system and having citizens being in charge of local government and not business interests.

The overlooked part of the growth machine thesis is the normative and prescriptive portion. The ideal is that cities should be controlled by the citizens who live there and not business interests exploiting land for accumulation purposes. Furthermore, Logan and Molotch called for U.S. cities to cooperate together to stop competing in chasing capital and defeat the growth machine system. The fact that this part of the theory exists does not detract from the larger, empirical portion of the theory and its explanatory power of political structure and agency in communities. ${ }^{65}$

The growth machine thesis is from the urban political economy school of thought which gets its origins from neo-Marxist thought. However, it eschews Marxism as a whole due to Marxism's economic determinism. Urban Political Economy holds that politics do matter. The growth machine thesis along with regime theory was able to supplant the elitism-pluralism debate as urban political economy could account for divergent situations.

The growth machine thesis is different from regime theory based on its emphasis on human activity or agency. In this case the prime human activity is economic development activity. Regime theory focuses on the structural part of government and is actually more inclusive due to its avoidance of agency, whereas the growth machine

\footnotetext{
${ }^{65}$ The writer feels that by no means does accepting the empirical portion mean obligation to the empirical and normative portion.
} 
thesis is precise as to what types of human agency occurs and it also identifies the types of actors engaging in the activity.

The growth machine thesis has been investigated through both quantitative and qualitative research studies. Overall, the quantitative research studied subsidiary questions as to the ideal outcomes of growth machine apparatus activities and consisted of relatively few studies. The body of qualitative research on the growth machine thesis was larger in size and consisted of both U.S. and international studies. Growth machine apparatuses were identified in numerous U.S. localities. ${ }^{66}$

Like any theory, the growth machine thesis has its strengths and weaknesses. In this case the primary strength of its specification of agency (growth is the essence of local politics and certain categories of elite actors are going to be the ones in control) is also its weakness. While it is not a perfect theory the growth machine thesis has stood the test of time in explaining the local power structure and prime agenda of local movers and shakers in the United States.

\section{Implications for Local Healthcare Policy}

\section{The Usefulness of the Growth Machine Thesis}

The growth machine thesis presents as a useful theory to study local healthcare politics and policy for several reasons. First, local hospital/healthcare systems tend to be locally-embedded and dependent organizations that have large numbers of employees.

Even though many researchers are concerned that the poor get access to care (and they are focused to that extent), healthcare tends to be a crucial sector of the local economy of

\footnotetext{
${ }^{66}$ As noted in an earlier footnote growth machine apparatuses existed in a few Canadian localities and numerous outside of North America. A consistent theme that ran through international investigations: differing governmental structures and arrangement of relationships with national governments spearheading the development agenda meant for difficulty in making the growth machine thesis fit.
} 
larger cities and enables a multiplying effect by re-circulating healthcare costs as wages back into the economy and the local tax base.

Local healthcare systems (which the exception of proprietary ones) are governed by voluntary boards of local business elites. The elites are connected individuals who can link an organization with resources or enable the organization to further its mission and improve its position in the market or community. Within constraints of organizational bylaws, these boards tend to be self-perpetuating and new members are appointed by informal political means. ${ }^{67}$

Where the growth machine thesis appears to be especially useful in studying local healthcare politics is that these non-profit, major employers can be economic development tools where there is a university medical school that trains physicians and conducts research; this is especially true in the case of Louisville, Kentucky. Medical school research can be expanded outside teaching hospitals and channeled into commercial ventures which in turn evolve into the development of desirable high tech sectors with high wages that contribute even more to the tax base than information and service jobs. A term that comes to mind for this phenomenon is growth pole. ${ }^{68}$

\footnotetext{
${ }^{67}$ Some hospital organizations have by-laws requiring certain types of appointments, such as clergy or church members from the related religious denomination.

${ }^{68} \mathrm{~A}$ growth pole is a location of attraction for innovation because the conditions and resources are available. Examples of growth poles are Silicon Valley and the Research Triangle Park in North Carolina.
} 


\section{CHAPTER III}

\section{LITERATURE REVIEW}

\section{Overview}

This chapter is an exhaustive review of the scholarly literature about local healthcare politics and healthcare governance in accordance with Lennarson-Greer's (1997) definition of "urban health politics" discussed in Chapter I. This review is relatively brief due to little existing pertinent research in this area.

The structure of this chapter is thematic in terms of the disciplinary studies sociological, public health and urban studies. There will be a summative conclusion drawing connections with the hypothesis.

\section{Early Sociological Studies}

The identified early studies on local healthcare decision-making were from sociology. Themes in the pertinent sociological literature center on community elites having control or leadership.

Belknap and Steinle (1963) conducted a comparative case study analysis of two communities and their hospitals, using positional and decisional analyses. ${ }^{69}$

In their positional analyses of the identified hospital boards it was evident that local business interests dominated the memberships. ${ }^{70}$ These individuals were not

\footnotetext{
${ }^{69}$ They also discussed the interaction in one community between the county health clinic and one hospital. The discussion was in terms of delivery of services and referrals and not of a matter of political interaction. The doctors were central in this interaction.
} 
necessarily from the most elite cliques in the communities, but were mostly from the second, third, and fourth levels of elite social cliques. In their tabular presentation of the memberships, banking and parochial business owners were dominant on each board. Only one of the boards had consumer-level community members or "jobbers," while the other two boards consisted of local business elites (pp.123-124).

Belknap and Steinle also compared the community connections between a "restricted" and an "unrestricted" hospital. The restricted hospital served only paying patients and the unrestricted had a paying patient and charity/indigent patient mix. An interesting observation made by Belknap and Steinle was that the unrestricted hospital was a type of "utility" for the paying patient but a charity for the indigent (p.39). They noted that the restricted hospital serving only paying patients relied only upon five stakeholders while the unrestricted hospital depended upon a much more complex (if not outright fragmented) mix of stakeholder groups (pp.37-38).

Belknap and Steinle found that the processes of facility development and improvement communities required "a reasonable unity between formal governmental leadership and community leadership in major civic, economic, social, and cultural groups" (p.89). In the "Watertown" community there was a committee initiated by the

\footnotetext{
${ }^{70}$ Belknap and Steinle list board memberships in tabular form along with the professions of the members. On the "James Memorial Hospital" board in "Watertown" the 13-member board had four bankers, one newspaper owner/editor, two factory owners, one retail store owner, one real estate agent, one physician and one "consulting geologist (p 123). On the Centralia "Mercy" Hospital Board, the 15 members consisted of four bankers, one factory owner, one dentist, one physician, one architect, one retail owner, one veterinarian, one theater owner, one building contractor, one trucking company owner, one realtor. The 13-member Williams Hospital board in Centralia had three bankers, a warehouse owner, one plant owner, two "jobbers" (or likely non-elites) an owner of a local grocery chain, one optometrist, one realtor, one retailer, one accountant. (p.123). The bottom line is that the memberships were monopolized by local interests/elites.
} 
local medical society to expand the "unrestricted hospital" "71 that included the publisher of the local newspaper (p.134). Furthermore in Watertown, the newspaper was involved in campaigning for the hospital through published feature stories (p.141). Their major conclusion was

that a full service or unrestricted community hospital system should not be organized without complete and continuous support from both the economic and political leadership of the community (p.202).

Elling, a contemporary of Belknap and Steinle, co-authored a number of case and comparative studies suggesting that economic elites were central in local healthcare governance. Elling and Blankeship (1962) demonstrated that "the community influentials" were connected to and involved with the hospitals in the upstate New York community they studied. Elling and Lee (1966) found in a small study of Pittsburgh community leaders $(\mathrm{n}=31)$ that "economic dominants were much more heavily concentrated on the boards of voluntary coordinating agencies and hospitals than other types" (of leaders). ${ }^{72}$ However, these "top influentials" had little formal connection with the county health department (p.302). Elling and Blankeship (1971) also found that the hospital relationally closest to the community power structure fared the best in terms of getting community support.

In a more general, narrative sense, Starr (1982) conducted a sociological and historical analysis of American medicine and the founding of hospitals. Starr's focus was on the national level, but some of his findings lend themselves to generalization on the local level. One such finding is Starr's conclusion that physicians were historically

\footnotetext{
${ }^{71}$ The "unrestricted" hospital was one that accepted indigent patients while the "restricted" hospital in Watertown took only patients who could pay.

${ }^{72}$ Pittsburgh is of fascination to Urban Scholars through the dominance of nonprofit foundations as the vehicle of regional governance and economic development.
} 
dependent upon the capital and philanthropy of influential business elites to establish hospitals. In turn the elite donors enhanced their statuses in the community (pp.152-153).

In terms of a general policy evaluation within sociology, Morone (1982)

examined how planning bodies of average citizens established by the National Health Planning and Resource Development Act of 1974 failed because they were a threat to local politicians and administrators. The local politicians were able to undermine those organizations. $^{73}$

In terms of sociological analysis of specific communities, Plano (1999) studied various reconfigurations of Toronto and Milwaukee healthcare organizations. He noted that different interest groups made decisions, but he was vague in identifying the interest groups.

The early sociological studies pointed to the domination of the elite in healthcare governance. They were also involved in the development of new facilities and the expansion of existing facilities.

\section{Health Policy Studies}

This section will review the studies by public health researchers. There were a variety of foci and thus a variety of outcomes. Some of the public health findings were similar to the sociology findings. ${ }^{74}$

Contemporary to Elling, there was a National Commission on Community Health Services, which had a mission "to study community needs, attitudes, resources, and practices and in turn translate the gained "knowledge into effective health services." This

\footnotetext{
${ }^{73}$ Morone's observations are discussed in further detail as it relates to the HSA that was in Louisville from 1967-1982.

${ }^{74}$ Some of the public health studies did not make conclusions.
} 
was a multi-faceted research effort to improve healthcare services (Marion in Wilson, p4$5){ }^{75}$ The result was multiple volumes on those different aspects of research.

Conant and Wilson studied the politics of community health from two different frames of reference. Conant studied the decision-making process through case study methods, while Wilson studied structure through a process analysis.

Conant's (1968) study consisted of case studies on five communities that used different planning models. Conant found that there was little success in terms of outcomes. He wrote:

The 'models' are simply good examples of the tangled political jungle that characterizes all public planning when it crosses the boundary line between fact finding and implementation (p.14).

He found much conflict and little implementation of planning.

The nature of Conant's conclusions reflects the fact that his research was qualitative. He was looking for "success stories" based on concrete action on specified goals; evidence of a viable relationship between health planning and other planning efforts such as city, regional or state planning; and the breadth of participation of relevant interest groups such as health agency leaders, school officials, hospital administrators and the like" (p.14).

Conant was looking for rational-comprehensive planning activity in the five communities and was openly disappointed. He discovered that health issues were a low priority except in time of crisis, and that civic leaders otherwise viewed the existing services, as adequately meeting needs. Second, civic leaders not involved in health agencies were usually reluctant to be interviewed for his research. Third, the general public was apathetic and ignorant. Fourth, given the apathy and ignorance of the public and local civic leadership, professional administrators with an agenda of self-protection

\footnotetext{
${ }^{75}$ This was from a duplicated preface in both Wilson and Conant as they were from the same book series.
} 
dominated the situations. Fifth, self-protecting administrators used the power of civic leaders as organization board members to maintain territories. Conant found that health planning activity was ad hoc in nature in those five communities (pp.17-18).

Wilson's study covered all 21 communities in the National Commission on Community Health Services' project, and not just the five that Conant focused on. Wilson (1968) found that economic leaders had more informal influence in health planning than political leaders and professionals. Informants indicated that approaching the economically influential figure was more effective than approaching the politician (p.85). Wilson also clarified that economic leaders were of more general influence than specific influence on health issues (p.98). ${ }^{76}$

Both Conant and Wilson identified a tendency toward incrementalism and health projects that did not challenge the status quo in communities. Also, there was no steady agenda or stream of activity at the local level. Furthermore, there was a consistent view that health decision-making was not a matter for the average citizen but for ensconced agency administrators buttressed by supportive civic and economic elites controlled it.

Alford (1975) focused on New York City's health system. His “general theoretical perspective" was that healthcare institutions "must be understood in terms of a continuing struggle between major structural interests operating within the context of a market society." From this perspective, professionals control resources while "corporate rationalizers" challenge for control, and the general population seeks improved services through advocates (p.xiv). Alford argued that within healthcare a tension has existed between bureaucratic reformers and market reformers (pp.1-2). Alford called the state

\footnotetext{
${ }^{76}$ Wilson stated this in a chapter endnote in what reads as an anecdotal conclusion. There were no specific illustrations.
} 
"Certificate of Need" laws a victory by bureaucrats over market reformers, as the expansion of facilities has had to be approved by administrative decision (p.202). He also suggests that there will be little to no popular control of healthcare due to the heterogeneity of community populations; they are too fragmented to negotiate with the structural interests (pp.220-222). ${ }^{77}$

Ginzburg (1977) noted that the typical nonprofit community hospital was controlled by elites.

The community hospital reflects, in most instances, an alliance between the community's elite (or some sub-section based on ethnic, religious, or other group identification) and some segment of the medical profession - usually the personal physicians of that hospital's trustees and supporters. Historically the elite raised the capital for-and retained control over-the hospital, although the medical staff determined day-to-day operations and initiated most new medical programs.

Ginzburg viewed hospital board membership as a long-term paternal matter as multiple generations of affluent families have sat on the same hospital board (p.3). While Ginzberg gives little citation in his book, his views seem consistent with those of Elling, Conant, and Wilson.

Litman and Robins (1984) devoted one half of one page in their textbook to health politics at the local level. ${ }^{78}$ Their discussion about local political structure seemed incidental as they focused on participatory democracy or the lack thereof. They noted:

Historically, participation of the public in the making of health policy decisions was subsumed in the involvement of the community power structure in institutional governance-a pluralistic, class-based system (p.20). ${ }^{79}$

\footnotetext{
${ }_{77}^{77}$ Alford's argument seems very much structured like a political economy argument.

${ }^{78}$ Litman and Robins use the term "pluralism" to describe their view of local politics. In the healthcare literature refers to the autonomy of doctors. In urban affairs pluralism refers to popular or democratic control.

${ }^{79}$ Vogel summarizes that "Pluralists contended that government dominates the community's decisionmaking processes" (p. 12). Therefore, they could be called pluralist, but their lack of discussion about decision-making processes makes labeling their view as pluralist inappropriate.
} 
There are a number of international public health authors worth noting. Tulchinsky and Varavikova (2000) discussed the local level of healthcare activity in bureaucratic, but not political, terms as part of the federal system (pp.530-532). Bodenheimer and Grumbach (2005) described policies in generalities, and their discussion of community health centers (while governed locally) was in terms of the federal level and not the local level (p.60-62). These books were devoid of any discussion of local political action.

Gentile-Donnell (2004) studied in-depth the chronology of a Philadelphia public hospital's closing as it related to the various levels of formal government, but she did not discuss the role of informal political actors in the community. Her political discussion was limited to the activity of formal government.

\section{Urban Studies}

There were several works by urban studies authors. The studies seem reflective of their times.

Swanson's (1972) chapter in Freeman, Levine's and Reeder's Handbook of Medical Sociology, was written in terms of a formal government or elected official perspective and did not discuss the process and structure of local political activity. ${ }^{80}$ Swanson offered a complex "cybernetic" political model of seven variables ${ }^{81}$. In this model different formulations can be made for explaining government's involvement in healthcare on any particular level. Swanson's variables were

- system output,

- system stress (political contention, controversy, and conflict),

\footnotetext{
${ }^{80}$ Swanson's model has a seminal quality to it, but is similar to other types of complex models in Urban Affairs.
} 
- system inputs,

- power structure, $^{82}$

- political ideologies,

- political focus, ${ }^{83}$

- system change processes $^{84}$ (pp.443-454).

In Swanson's model, the actors in local health politics utilize different mixtures of the variables to achieve desired policy results.

Swanson's work is indicative of the era before the wave of healthcare mergers and hospital closings, and the general tendency of city governments to move out of the direct provision of healthcare. His work also appears to be indicative of the time period prior to the movement from community power towards the urban political economy school of thought. However, Swanson's accounting for variables and the tensions along the lines of those variables, suggests that it may be adapted for political economic analysis.

Schussler's (1994) dissertation discussed the manifestation of American Corporatism $^{85}$ in the process of Humana landing the management contract for the University of Louisville Hospital. Through a heuristic case study, Schussler explored how indigent care could be delivered through a public-private partnership (pp.1-2). He

${ }^{81}$ This model seems similar to the model by Clark (1968) on community decision-making (pp.15-21).

${ }^{82}$ The four types of power structures are: consensual mass, consensual elite, competitive mass, competitive elite.(pp.448)

${ }^{83}$ This refers to the whether the preference will be achieved by the decision-making structure used, the decision-making process uses, whether Public policy is used, whether financial resources are manipulated, or whether personnel engaging in their activities as the tool for achieving the preference.

${ }^{84}$ This refers to the tools used to achieve change or maintain the status quo (reform = incremental change, politicization or creative change $=$ comprehensive change, professionalization or mediation $=$ maintaining the current government scope, managerial = contraction) $(\mathrm{pp} .433-434)$.

${ }^{85}$ Corporatism refers to the high degree of cooperation between government and business in governance of a city. 
was focused on the state level and not the local level, but his study included interviews with local political actors and their interaction with the state. The outcome was that the city of Louisville persuaded the state of Kentucky to build a new public hospital, and Humana, a major local corporation, got the contract to manage it.

While this is more sociological in nature than belonging to the field of urban studies, Britton and Ocasio (2007) explored as a part of their larger study ${ }^{86}$ the historical applicability of the growth machine thesis to hospital and orphanage location in Chicago between 1848 and 1916. Their assumption was that local elites supported the creation of these organizations in growing areas in the name of "maximizing symbolic benefits" (p.1306). Britton and Ocasio supported Logan and Molotch's view that hospitals were placed in locations to create greater visibility of the "material and symbolic benefits provided by these facilities." $\$ 87$

Britton and Ocasio's starting point was Logan and Molotch's (1984) article, which suggested that during the period of private charity dominance, the local, industrial elite's contributions towards the construction of hospitals, orphanages, and university buildings "had important symbolic benefits for growth ideology, quite beyond their actual material significance in creating better lives for citizens." Conspicuous examples of this included the contributions of the Ball Family in Muncie, Indiana (Ball State University/Ball Memorial Hospital) ${ }^{88}$ Eastman's contributions in Rochester, New York, and the Mott family (General Motors) contributions in Flint, Michigan (p.485).

\footnotetext{
${ }^{86}$ This study also considered the Human Ecology and Spatial Density Dependence views.

${ }^{87}$ Britton and Ocasio's results may have been different if they would have taken out orphanages.
} 


\section{Conclusion}

This has been a brief literature review of the pertinent research on the local aspect of healthcare politics and urban health politics as defined by Lennarson-Greer. The brevity of this summary is due to the small quantity of pertinent scholarly work.

An attempt was made to be exhaustive in a review of the pertinent literature. There are numerous articles with titles that connoted relevance, but proved to be irrelevant as the subject matter lacked any meaningful discussion about the way cities defined and set about meeting their healthcare needs. These articles discussed identification and actions of local political actors and the patterns of local political behavior. ${ }^{89}$ The literature search results affirm Lennarson-Greer's statement that public health scholars ignored the local or place aspect of healthcare politics.

Overall, there was a patchwork of public health and sociological studies having relevance to local healthcare politics. It seems that this area has not been of significant interest to many sociological and public health researchers, or perhaps healthcare has indeed been looked at as a utility or charity instead of a matter of production and development.

The relevant sociological research suggests elite domination of healthcare governance, as hospital boards were found to be dominated by local business interests or economically influential figures. On the other hand, there was a suggestion by one public health source which cited that there was evidence for pluralism, but the usage of the word is vague and thus of little use in supporting political pluralism.

\footnotetext{
${ }^{88}$ These are included based on the writer's personal knowledge of Muncie, Indiana having lived there. ${ }^{89}$ Hunt (2005), McAvoy, P.V., Driscoll, M.B., \& Gramling, B.J. (2004), Adams (2003), Needleman (2001), Millman (1981). What is particularly disappointing is that Adams was in the Journal of Urban Affairs, but her focus is on state-level politics and not local level politics.
} 
Some authors seemed to focus on the agency or pattern of activity. Alford concluded that there is a tension in understanding the political activity while Swanson constructed a cybernetic model allowing for the complexity of inputs and outputs.

There was an absence of looking at a city as a whole unit as well as failure to identify agendas and mechanisms for political activity. Plano deserves some recognition in terms of specificity, with the above noted concerns. Belknap and Steinle come the closest to looking at cities and making conclusions about the processes. While insightful and also similar to recent urban political economy thought, Alford's focus is on a system within New York City and not the city itself. Overall, suggestions have been offered as to political structure and process, but there has been no definite attempt to describe who is in charge of healthcare within a city and how they function.

There are affinities between the cited sources and Logan and Molotch's 1984 article about the involvement in the growth coalition in the formation of community charitable and social institutions. Despite Schussler's focus on corporatism in Louisville connoting a close non-competitive alliance between business and government, his work could be harmonized with the growth machine thesis (p.29). Humana, the private contractor running the University of Louisville Hospital—while not necessarily a locallydependent firm, was founded and has maintained its headquarters in Louisville, and has been a powerful institution in the city, influencing local political activity by its executives.

Overall, the literature found on the local aspect of healthcare politics appears to lend general support to some tenets of the growth machine thesis. In terms of structure, there is a tendency for locally-based elites to be influential in decision-making and hold 
positions of power. While Belknap and Steinle, Alford, and Conant identify some agency or human activity aspects, the literature demonstrates a lack of understanding of what drives local political activity agendas at the city level. With one exception, it appears that the existing literature has not looked at local healthcare matters through the lens of the politics of production or development with the useful nuances it offers. 


\section{CHAPTER IV}

\section{HISTORICAL ANALYSIS PART \#1: THE LOUISVILLE MEDICAL CENTER \\ Overview}

The Louisville Medical Center as it stands in the $21^{\text {st }}$ century is a densely arranged complex of modern to state-of-the art healthcare facilities covering over 20 square blocks in downtown Louisville (The Encyclopedia of Louisville, p.559). It consists of Jewish Hospital, Frazier Rehab Institute, Kosair Children's Hospital, Norton Hospital, the University of Louisville Hospital, the University of Louisville Medical, Dental, Public Health Schools and clinics, a shared steam plant, and a multitude of doctor offices. The major hospitals in the Medical Center are teaching hospitals for the University of Louisville Medical School. The Louisville Medical Center did not happen by accident and this chapter will explore how the growth coalition or growth machine apparatus created it in the 1940's and 1950's.

Using available sources, this chapter (as a historical content analysis) demonstrates the growth machine thesis' applicability to Louisville's past healthcare political actions. The process of the Medical Center's creation is a demonstration of the growth machine thesis in past Louisville healthcare politics.

There were two stages in how the growth machine thesis was applicable to the development of the Medical Center. The first stage was the early formation process (1944-1955). The second stage was the process of getting the now-defunct Methodist 
Evangelical Hospital (MEH) built in the Medical Center complex. ${ }^{90}$ The growth coalition possessing a political agenda of growth made both happen.

Since the growth machine thesis is a general, abstract theory of structure and activity, the challenge therefore is articulation of the complex aggregations of people, events, and agendas fit into the patterns suggested by the theory. If the empirical portion of the growth machine thesis is a valid explanation of past healthcare politics, then there will be evidence of a growth machine apparatus consisting of elite individuals cooperating together with growth agendas over the observed time periods.

Domhoff and Dye (1987) suggest that a historical content analysis is a part of power-structure research. They said that such a study is

conducted on the memos, minutes, letters, speeches, position papers, and legislative proposals that are produced by central organizations and well placed leaders within the network of elite institutions and people (p.11).

They note that this kind of research is limited to the researcher's "general impressions based upon an application of his or her subjective categories to the material under inspection..."(p.11).

This chapter argues that the growth machine thesis explains past local healthcare politics in Louisville between 1945 and 1958 as suggested by Molotch. Molotch suggested that such a continuity can be traced backwards (1999, p.249). ${ }^{91}$ The growth machine apparatus's structure and activity can be identified in the formation of the Louisville Medical Center. The power to define local healthcare needs and assemble the

\footnotetext{
${ }^{90}$ Norton Hospital moved to the Medical Center in 1969 after merging with Children's Hospital, but the political activity over its relocation from Third and Oak does not come across in the available material as being significant.

${ }^{91}$ Molotch's quote is as follows: "The growth machine idea does make a substantive argument about the empirical substance of U.S. urban regimes. It asserts that virtually every city (and state) government is a growth machine and long has been" (p.249).
} 
resources to meet them was a parochial elite activity. Louisville city government was a peripheral player in the development of the Medical Center complex and not central until later in the timelines. However the University of Louisville was both a central player and tool of growth in this process. Overall, the growth machine apparatus structure and activity is evident and there is clear indication of a growth agenda in the process of Louisville healthcare politics in that time period.

This chapter will have the following structure. The information sources and their limitations will be discussed first. The process of establishing the Louisville Medical Center will be reviewed. The saga of the growth coalition persuading MEH to build in the Medical Center versus another location will be reviewed. This chapter will end with a conclusion and analysis.

\section{Information Sources}

The information sources for this chapter are printed history sources. There are several types of available, printed sources: published histories, newspaper articles, and archival documents.

Howell and Prevenier (2001) warn of the need to be mindful about the conditions in which a source was produced, the motivations behind its production (pp.17-19). ${ }^{92}$ The published histories of hospitals were printed at different times for different authorial intents, but primarily were written to celebrate or commemorate ${ }^{93}$. The published histories were selective and nostalgic with public relations intent versus educational

\footnotetext{
${ }^{92}$ Howell and Prevenier also expressed concern that just knowing the conditions do not tell all about the reliability of the documents. Placing said events documented in the historical context is the heart of historical interpretation (p.19).

${ }^{93}$ The history of Methodist Evangelical Hospital was completed in 1994 after the hospital had been merged into the Alliant (now Norton Healthcare) system and the edifice effectively stopped being a separate hospital in 1993 and thus the volume was commemorative. The other reviewed histories were thus celebrations of historical milestones.
} 
intent about the political issues. Nevertheless, the published hospital histories identified that the Louisville Medical Center was a city-wide political matter in Louisville and appropriate for further analysis.

The Louisville Courier-Journal and Louisville Times were prime sources of newspaper coverage. ${ }^{94}$ The pertinent stories were identified in the clippings files at the main branch of the Louisville Free Public Library and the microfilm index of the University of Louisville Archives and Records Center at the Ekstrom Library. ${ }^{95}$ Some of the newspaper articles and editorials were already quoted or cited by the published hospital histories, which again provided cues for further analysis.

There are two weaknesses of the available newspaper records that are potential threats to validity. First, the dependency upon clipping files and microfilm indexes has the inherent risks to validity of human error and record corruption. Second, the data found in the newspapers is limited and it is possible restraints existed to avoid offending elite individuals. ${ }^{96}$

Archival materials in the form of social documents (Howell and Prevenier, p.22) came from several sources. ${ }^{97}$ The University of Louisville Records and Archives Center had original documents and correspondence from files of two (2) University of Louisville presidents and the Louisville Area Development Association. The Louisville Free Public Library had some original Louisville Area Development Association brochures. Some duplicate items from the University of Louisville archives were found at the City of

\footnotetext{
${ }^{94}$ The locally resident Bingham family owned both papers for the relevant period of time during both events. The Courier-Journal was the morning paper and the Louisville Times was the evening paper. ${ }^{95}$ The Louisville Free Public Library also offers microfilm of the Courier-Journal.

${ }^{96}$ Logan and Molotch (1987) wrote that "The newspaper has no ax to grind except the one that holds the community elite together: Growth" (p.71). Therefore there is the suggestion of bias.

${ }^{97}$ Howell and Prevenier note that social documents are the products of record-keeping by bureaucracies such as government departments, charities, foundations, churches, and schools (p.22).
} 
Louisville Archives. ${ }^{98}$ Overall, there is strong indication that more happened for which archival records do not exist. ${ }^{99}$

In order to be exhaustive, the Filson Historical Society, the Bellarmine University Library, the Spalding University Library and the State of Kentucky Archives were all consulted. It appears that much potential archival material was either disposed of after certain periods of time as allowed by law by the Kentucky State Archives, or were likely destroyed by parties who may have considered the records to be of little to no significance.

\title{
The Louisville Medical Center Development Process
}

\author{
Early Formation Process
}

The sense of a Louisville Medical Center appeared in some existence in the 1920's with the Children's Hospital being built near Louisville General Hospital (Encyclopedia of Louisville, p559). But for all political purposes the concept of a "hospital center" or "medical center" was not a matter of focus until 1945 when the growth machine apparatus decided to work on it and make it the reality it is now.

\section{Early Development Process}

\section{Initial Needs Assessment}

The process leading to the formation of the Louisville Medical Center started in May 1944 when The Louisville Area Planning Association (LADA), a forerunner of the Louisville Chamber of Commerce and Greater Louisville Inc began to explore healthcare

\footnotetext{
${ }^{98}$ The City Archives made Mayors' correspondence files from the Farnsley and Taylor administrations available that had yet to be catalogued. There was a file that was labeled Medical Center but it did not have any such documents in it and was sadly empty.

${ }^{99}$ For example, the LADA had numerical labels to meetings of a certain type of committee, and the first available meeting "minutes" was for meeting number three. The sequence jumped to meetings five, six, and seven, and then no more was available.
} 
needs for Louisville and to evaluate current facilities. The LADA was central to the process and took active leadership in the formation and development process of the Louisville Medical Center. This section is a chronological review of the process.

The LADA appointed an ad hoc "Subcommittee on Hospitals" that first met on May 24, 1944 to evaluate the current Hospital facilities (particularly the aging Louisville General Hospital physical plant) and to establish a course of action for different patient populations (Louisville Area Chamber of Commerce and Predecessor Records, University of Louisville Archives and Records Center). During this time, the LADA also hired a consultant from the University of Chicago to study Louisville General Hospital. This committee met at least five times with no further surviving records after December 14, 1944. A memorandum in the archival file indicated that members of this committee met with then Mayor Wyatt to discuss results in its last known meeting (Louisville Area Chamber of Commerce and Predecessors Records University of Louisville Archives and Records Center and Uncatalogued City of Louisville Mayors' Correspondence Files, City of Louisville Archives), and thus the city government was not involved until this time.

From what can be deduced from the limited archival information, the LADA continued pushing the agenda through both committee action and outreach by K.P. Vinsel, LADA Executive Director. Vinsel wrote a letter to Mayor Wilson Wyatt, asking for the Board of Health to pay for a survey to be conducted by a local doctor. On April 20, 1945 the regular standing LADA "Health Committee" considered a number of possible consultants to conduct a survey of hospital facilities to ascertain community needs (Uncatalogued City of Louisville Mayors' Correspondence Files, City of Louisville Archives). 


\section{The Bradley Report}

In 1945 the LADA hired Consultants F.R. Bradley and R.E. Raper of St. Louis, Missouri to do a "Preliminary Louisville Area Hospital Survey."100 The survey's purpose (completed in November, 1945) was to "determine needs for expansion after the war" (Bradley and Raper, 1945, p. 1 Presidents Files 1929-1971, University of Louisville Archives and Records Center). Bradley and Raper suggested that the minimum hospital size for economic viability in an urban area was 160 beds and only six of the 28 Louisville area hospitals were of that size. They suggested the idea of a medical center with institutions sharing facilities to achieve this viability. They also concluded that many of the hospital facilities in the Louisville area were obsolete and "a certain amount of hospital construction and reconstruction is indicated" (Bradley and Raper, 1945, p.17, Presidents Files 1929-1971, University of Louisville Archives and Records Center).

In early December 1945, J.J. Egan of the LADA Health Committee sent both University of Louisville president Einar Jacobson and Mayor Leland Taylor a copy of Bradley and Raper's report with an invitation to a meeting at the Pendennis Club. ${ }^{101}$ Egan's letter said that the LADA was "inviting representatives of groups planning the construction of hospitals and a few persons especially interested in the hospital problem ..." (Egan, Personal Communication, President's Office files 1929-1971, University Archives and Records Center, University of Louisville and Uncatalogued City of Louisville Mayors' Correspondence Files City of Louisville Archives).

\footnotetext{
${ }^{100}$ Several duplicates of this report exist uncatalogued in the City of Louisville Archives.

${ }^{101}$ The Pendennis Club is a historically exclusive gentlemen's club in downtown Louisville. It is in the middle of the downtown district and what was the central business district in the late $19^{\text {th }}$ and for much of the $20^{\text {th }}$ century. Numerous sources identified it as the site of informal discussions among community elite. It is probably most famous to the general public for "Henry Bain" Sauce. Informants said that it no longer is the center of such elite activity.
} 
The Special Committee on a Hospital Center

Archival records indicate that the LADA moved quickly, focusing on the Bradley and Raper recommendations through the creation of a "Special Committee on a Hospital Center" in early 1946. In the process of getting this committee started, K.P. Vinsel, LADA Executive Director wrote to Einar W Jacobson, University of Louisville President, and stated that he (Vinsel) hoped that the University could take the lead in development of the Medical Center (Vinsel Personal Communication, President's Office files 1929-1971, University Archives and Records Center, University of Louisville).

Records indicate this special committee met seven times from early 1946 to September, 1947 (Louisville Area Chamber of Commerce and Predecessors Records University of Louisville Archives and Records Center). ${ }^{102}$ The committee was composed of LADA members, representatives from the University of Louisville and various hospital organizations. Table 2 lists the actors. Lee P. Miller of Citizens Fidelity Bank, who was also on the University of Louisville Board of trustees, was appointed to this ad hoc committee but never attended any meetings (Jacobson Personal Communication March 7, 1946 President's Office files 1929-1971 University Archives and Records Center University of Louisville). Other than hospital representatives, the vast majority of members represented the growth coalition sectors. Otherwise, by virtue that the meeting took place under the auspices of the LADA, and not at City Hall or the County Fiscal Court (the county legislative body), growth seemed to be the guiding agenda of these efforts.

\footnotetext{
${ }^{102}$ The meetings of this special committee were actually numbered, and minutes exist for meetings, \#3 (March 19, 1946), \#6 (September 18, 1947), and \#7 (September 26, 1947).
} 


\begin{tabular}{ll} 
& $\begin{array}{c}\text { Table 2 } \\
\text { Meeting Participants } \\
\text { Name }\end{array}$ \\
\hline John V. Collis & $\begin{array}{c}\text { Locial Committee on a Hospital Center 1946-47 } \\
\text { Livelihood and Healthcare involvement }{ }^{104}\end{array}$ \\
Robert Bonnie & $\begin{array}{l}\text { Lawyer/None known } \\
\text { Corporate Capitalist/None known }\end{array}$ \\
J. Verser Conner & Lawyer/None known \\
H.M Cousins & Unknown/None known ${ }^{\text {105 }}$ \\
Einar Jacobsen & President University of Louisville/None known \\
John Moore M.D. & Medicine/Dean, U of L Medical School \\
Frank J. Pfeiffer & Utilities/Evangelical and Reformed Hospital Group \\
Milton Trost & Investment Banking-Stockbroker/Jewish Hospital \\
K.P. Vinsel & Executive Director/None known \\
K.H. McCracken & Staff member, LADA/None known \\
Carl Berg & Staff member, LADA/None known \\
Saul Ades & Corporate Capitalist/Jewish Hospital \\
C.A. Edinger & Corporate Capitalist/None known \\
Frank Gregg & Hospital Administrator/Deaconess Hospital \\
Franklin Starks & Rentier/Children's Hospital \\
William Flarsheim & Local Retail Executive/None known \\
\hline &
\end{tabular}

${ }^{103}$ Sources: Amster and Zingman, 1994, President's Office files 1929-1971, University Archives and Records Center, University of Louisville. Louisville Area Chamber of Commerce and Predecessors Records University of Louisville Archives and Records Center) Uncatalogued Mayors' Files City of Louisville Archives

${ }^{104}$ The Method of determining the sectors and roles came in the following manner. First, existing archival documents already possessed and Hospital histories were reviewed for any indication of sectors. Second, an obituary search was done using www.ancestry.com for dates of death. The Courier Journal Microfilms were accessed, Caron's directories were used last.

${ }^{105}$ H. (Henry) M. Cousins' sector could not be determined. If Caron's City Directory was incorrect (there was a listing for Henry S. Cousins), this person may have been a retired Utility executive. 
The three available sets of meeting minutes of this committee show slow progress overall in developing the Medical Center due to the lack of funds by the hospitals and the University of Louisville financial shortfall made it difficult to proceed with land condemnation, land clearing, and construction. There was also an inconsistency in the scheduling of meetings. In meeting \#3 (March 19, 1946), there was an early start in the economic analysis and specific discussion about land acquisition through the University of Louisville's statutory power of condemnation ${ }^{106}$ to " "to extend the usefulness of the University." But again, the University of Louisville was in no position to make the necessary financial outlay (President's Office files 1929-1971, University Archives and Records Center, University of Louisville). A year and a half later in meeting \#6 (September 18,1947 ) the minutes contain a statement by committee chairman Morton Boyd that none of the hospitals had actually decided yet whether they wanted to form a medical center. The Evangelical and Reformed denominational group was bogged down by a lack of funds while the Methodist group (planning to replace the old Deaconess Hospital) wanted to put their new facility on the old "Claggett Estate" in the south Highlands area of Louisville. ${ }^{107}$

Meeting \#6 (September 18,1947) of this "special committee" was attended by James Hamilton, a Minneapolis-based hospital consultant hired by the Children's Hospital, coincidently in town to consult with that institution (Mellor, 1992, p.53). Eight days later on September 26, 1947, the last known meeting (Meeting \#7) of the special committee was held. Meeting \#7 featured Hamilton's presentation ${ }^{108}$ about the

\footnotetext{
${ }^{106}$ K.R.S. 165.070

${ }^{107}$ This is actually the present day site of Atherton High School.

${ }^{108}$ Morton Boyd's letter of September 22, 1947 to University of Louisville President John Taylor had a concluding paragraph "We are very anxious to have you attend this meeting to hear Mr. Hamilton and to
} 
organization of other Hospital Centers around the country (especially the one in Houston, Texas) and a time of question and answer with Hamilton (President's Office files 19291971, University Archives and Records Center, University of Louisville).

\section{Initial Involvement of Local Government}

The sum of the hospital histories and the available documents indicate that Louisville City Hall was not involved in the development of the Medical Center until later in the process. Amster and Zingman (1994) reported that in May, 1947 then Louisville Mayor Leland Taylor suggested that the Veterans Administration build the proposed VA hospital downtown versus on Zorn Avenue. ${ }^{109}$ It was at that time the Mayor and Board of Alderman "went on record agreeing in principle to support a medical center" (p. 19). However, it remains that the city government stayed off to the side of this planning process until invited in by LADA and its Executive Director, K.P. Vinsel.

\section{Vinsel 's Initiative and Leadership}

While there is no record that the special committee met after September, 1947, it is clear that Vinsel continued to drive the process towards formation of the Medical Center forward despite the lack of commitment from the various hospital organizations. The Courier-Journal (Vinsel asks VA 1947, April 27) reported that Vinsel wrote both US Senators Alben Barkley and John S. Cooper, and Representative Thruston Morton requesting that the VA build the planned hospital downtown. The story reported that Vinsel had submitted a 26-page report that built an argument for why the downtown site was practical and the proposed Zorn Avenue site was "impractical." Vinsel later

participate in discussion of a Louisville Hospital Center." The inclusion of the word "anxious" may suggest some of the emotional atmosphere given all the gridlock. 
corresponded with hospital consultant James A. Hamilton about a survey of the facilities in the area. LADA records contain Hamilton's detailed proposal letter to Vinsel that work on such a hospital survey could begin shortly after January 1, 1948 (Hamilton Personal Communication December 16,1947). Furthermore, Vinsel was open with the relevant parties that he was soliciting funds from the Louisville Foundation ${ }^{110}$ for Hamilton's study (President's Office files 1929-1971, University Archives and Records Center, University of Louisville).

Hamilton's large report entitled A Hospital Plan for the Louisville Kentucky Area was presented to LADA in September $1948 .{ }^{111}$ It was given immediate publicity on page one in The Courier-Journal (Nunn, 26 September, 1948). Hamilton made 95 specific recommendations (pp.SR-1 -SR-13 Louisville Area Chamber of Commerce and Predecessors Records University of Louisville Archives and Records Center). Hamilton made specific recommendations for each hospital operating in the Louisville area to include Clark and Floyd Counties in Indiana. Some of the recommendations included:

- Organize a nonprofit entity called the "Kentucky Memorial Medical Center."

- The existing Children's Hospital and Louisville General Hospital should become part of the medical center.

\footnotetext{
${ }^{109}$ However, this also contradicts that Mayor Taylor signed over a deed from the Louisville Water Company to the United States of America on September 23, 1947 (D.B. 2288 P.54-56) David Morgan, Louisville City Archivist Personal Communication July 5, 2007.

${ }^{110}$ The Louisville Foundation is still in existence today and it is a low-key organization.

111 It is evident that Norton was not part of any of the process of creating the Medical Center. There is no mention of it in McGowan-Mellor's (1998) history of Norton. A conclusion that can be drawn from the Hamilton report was that Norton apparently was in a good fiscal and operational position in its location at Third and Oak Streets compared to that of Jewish and Deaconess, and that it was not in its interest to relocate at that time. The Hamilton Report in fact recommended that it expand (p.SR-5) (Louisville Area Chamber of Commerce and Predecessors Records University of Louisville Archives and Records Center).
} 
- Jewish Hospital, Methodist Deaconess Hospital, and the Evangelical Reformed Hospital organization all should build new physical plants in the Medical Center. ${ }^{112}$

- The proposed medical center should have centralized services to include a laundry, a linen service, purchasing, and a centralized steam plant for power, light and steam to all units in the medical center.

Hamilton and his associates encouraged a state orientation versus a local orientation, which included a recommendation that the University of Kentucky take over operation of the University of Louisville Dental School. Furthermore, Hamilton recommended that leaders move quickly and have new facilities in place by 1950 . He also recommended that leaders plan big for 3,260 beds in the Medical Center by 1970 (Louisville Area Chamber of Commerce and Predecessors Records University of Louisville Archives and Records Center).

The Cooperative Attempt to Implement the Hamilton Report Recommendations

The LADA led an almost immediate and concerted attempt with Louisville city government and the University of Louisville to implement recommendations \#30 and \#47 of the Hamilton Report ${ }^{113}$ which were that the Veterans Administration (VA) and Jewish would build new hospitals in the Medical Center. This was a formidable challenge given that the VA was already planning to build a facility on Zorn Avenue east of the downtown district. There are several documents that show elite cooperative efforts in this failed attempt.

\footnotetext{
${ }^{112}$ The report also suggested that Sts Mary and Elizabeth Hospital consider being part of the Medical Center but did not emphatically recommend that.

${ }^{113}$ Direct Quote:" 47 -That the new Veterans Administration Hospital planned for Louisville be constructed on a site within the Medical Center, thus assuring it the best possible professional staff with resultant high quality of care to its patients and making possible the saving of an estimated $\$ 200,000$ in site improvements." (p.SR-7 Louisville Area Chamber of Commerce and Predecessors Records University of Louisville Archives and Records Center).
} 
A memo in LADA files dated December 7, 1948 likely authored by John W.

Moore M.D, Dean of the University of Louisville Medical School, detailed a trip to Washington, D.C. Moore and Dr. Arnold Griswold met with Veterans Administration officials. ${ }^{114}$ The memo reported that then Louisville Mayor Charles Farnsley had made a phone call to a particular administrator one hour before Griswold and Moore visited faceto-face with the same administrator. The text of the memo reported that "The mayor promised to condemn sufficient land around the General Hospital and give it to the Veterans Administration for a hospital site." The memo reviewed the VA's objections to moving the hospital site and the type of local political action necessary to overcome the VA's objections ${ }^{15}$ (Louisville Area Chamber of Commerce and Predecessors Records University of Louisville Archives and Records Center).

Two other existing LADA documents indicate elites met privately on December 15, 1948 and agreed to cooperate on furthering the proposed Medical Center. K.P. Vinsel wrote Saul Ades, (then board president of Jewish Hospital), and informed Ades that the University of Louisville President, the Mayor, and several university trustees would meet with Vinsel. Vinsel wrote that the "purpose of the meeting will be to determine the attitude and interest of the Board members and the next step to be taken."116 The second document was a memo by Vinsel dated December 31,1948 distributed to Mayor Farnsley,

\footnotetext{
${ }^{114}$ See Table 2. The Dr. Moore on the LADA special committee was John W. Moore, and the Dr. Griswold on the special committee was Dr. Arnold Griswold. This memo appeared to be written by someone not experienced in writing memos as it did not specify an author or a date of authorship but identified who did what. It appeared to be written for a small group of people who would have understood who was who.

115 According to the memo, the objections that the V. A. had were 1) they already invested $\$ 300,000$ towards the planned hospital, and 2) moving to a new site would delay completion by two years. What was needed was to 1) show that $\$ 300,000$ could be saved, 2) acquire the land immediately to prevent any further delay in construction, and 3) secure the support of members of congress to protect the V.A. if the plans were to be scrapped.

${ }^{116}$ This was a copy of the letter forwarded to Dr .John Taylor, University of Louisville President.
} 
University of Louisville president Taylor, Dann C Byck (Local retail store owner and then President of the Louisville Board of Aldermen), and Verser Conner.

In his memo Vinsel spelled out the delegated tasks to different elite attendees to further the Medical Center in that December 15 meeting. Mayor Farnsley was assigned to contact United States Vice President Alben Barkley and get his assistance in delaying the VA from constructing the proposed VA Hospital on the Zorn Avenue site until a bond issue vote could occur in November, 1949. Byck was delegated to talk the Louisville Board of Alderman about a bond issue of $\$ 2,000,000$ to purchase land for the downtown VA hospital site. A Courier-Journal article indicates that Byck kept his end of the deal for the most part as he pitched such a proposal to the Aldermanic Finance Committee and secured their support (Byck Asks VA, January 22, 1949). President Taylor was to facilitate a meeting between the University of Louisville Medical School and Jewish Hospital to work out affiliation details. Lastly the University of Louisville was to meet with Jewish Hospital board members to discuss locating their new facility in the Medical Center (President's Office files 1929-1971, University Archives and Records Center, University of Louisville.). The archival information about LADA activity in the development of the Louisville Medical Center stops here, and the remainder of the information on this particular political activity story is dependent on available hospital histories and newspaper articles.

The newspaper coverage indicates that the local elite failed to convince the VA to put the VA hospital downtown in the Medical Center. Amster and Zingman reported there was significant resistance to such a move in other arenas. Amster and Zingman reported opposition by the American Legion and VA doctors. The VA doctors were 
concerned about being "'taken over by the university professors"' (Amster and Zingman, 1994, p.20). ${ }^{117}$ The Courier-Journal quoted Thomas Hayden, state adjutant for the American Legion in Kentucky who said "'This is not a Louisville project. It is for veterans of this whole area. Their interests are to be served and not that of the city"' and that veterans had waited long enough for a new VA facility (Byck Asks VA January 22, 1949). The cruxes of the VA argument for not acquiescing to Louisville's development interests were that the Federal Government had incurred sunk costs in the Zorn Avenue site, and the constituency of veterans opposed any further delay. ${ }^{118}$

\section{Cementing Jewish Hospital's Relocation and Formal Organization of the Center}

Despite being involved in the Medical Center discussion, Jewish, like the Methodist group, was looking at the south "Highlands" area of Louisville proper for a new facility site. While they were considering a site near the corner of Poplar Level Road and Eastern Parkway, the Jewish Hospital board hired the aforementioned consultant James Hamilton exclusively in 1949 to advise them on their options. Hamilton advised them that Jewish Hospital's future was with the University of Louisville Medical School and that they should explore possibilities with the medical school dean, which they did.

The discussions evolved to the University of Louisville offering land for the new facility in the location recommended by Hamilton. $\mathrm{U}$ of $\mathrm{L}$ would condemn and acquire the land with a "lease-back arrangement of one dollar a year for 99 years, provided

\footnotetext{
${ }^{117}$ A number of Courier-Journal articles indicate what Gardner summated about the different parties who protested. Whether the protests made a difference in the outcome is questionable.

${ }_{18}^{18}$ Efforts are being made again to replace the now old V.A. Medical Center with a new facility downtown in the Medical School.
} 
Jewish Hospital would make a contribution of $\$ 70,000$ to the University to help defray the costs of condemnation" (Amster and Zingman, 1997, p.68).

While the chronology is somewhat unclear between the U of L-Jewish agreement and what happened next, Amster and Zingman reported in both of their histories on the Jewish and Methodist Evangelical hospitals that in early 1950 two prominent Louisville residents, Rogers C.B. Morton ${ }^{119}$ met with Arthur Grafton Sr. ${ }^{120}$ met over lunch at the Pendennis Club to discuss formalizing the Medical Center. They jointly brokered a meeting with representatives from Jewish Hospital, Louisville General Hospital, and Children's Hospital. As a result of the meeting the Louisville Medical Center was formed on May 29, 1950 with Morton as the president of the organization (Amster and Zingman, 1994, p.21) (Amster and Zingman, 1997, p.68).

Amster and Zingman reported that Jewish still had difficulty accumulating funding to build in the Medical Center. They were aiming to get a $\$ 2$ for $\$ 1$ matching Hill Burton grant ${ }^{121}$ and they had to launch a campaign for further funds. Amster and Zingman observed "With the backing of the local press and community leaders, Jewish Hospital launched a major program to stress the need for more money." Amster and Zingman note that the program was successful but did not disclose the amount raised. ${ }^{122}$ In addition, the state of Kentucky Board of Health allocated over $\$ 384,000$ in additional funds (Amster and Zingman, 1997, p.75). The growth machine apparatus was able to get both public and private funds for the construction of a new non-profit hospital.

\footnotetext{
${ }^{119}$ A local industrialist and member of the University of Louisville Board of Trustees.

${ }^{120}$ A prominent lawyer

${ }^{121}$ The Hill-Burton Act and subsequent program was federal funding aimed at building new private hospitals in communities that had such need. It was a matching funds program.

${ }^{122}$ There was no visible coverage of this fund-raising campaign in the Courier-Journal.
} 
Lastly, there was a successful community referendum on a bond issue for constructing the steam plant. That was the last requirement for getting the Hill Burton funds (Amster and Zingman, 1997, p.75). The new Jewish Hospital was eventually built and opened in January 1955 (Amster and Zingman, 1997, p.75).

\section{Section Summary}

In concluding this section, the growth machine apparatus (not elected politicians), took both responsibility for and managed the evaluation and planning processes that led to formation of the Louisville Medical Center. The growth machine apparatus informally manifested itself as being larger than formal government. Under the auspices of the Louisville Area Development Association, the community elites were mostly growth coalition actors engaged in the redevelopment of land for usage for building new and larger hospital facilities. Local government was only consulted in terms of what it could bring to the table in terms of money, land condemnation and redevelopment. The growth coalition was able to get public money for both the Medical Center steam plant and for the Jewish Hospital facility in the Medical Center. While archival minutes report some discussion of redistributive policies, the dominant discussion was about developmental policies and the use of land within the city limits.

\section{The Saga of Methodist Evangelical Hospital}

This section will discuss how the growth coalition acted to compel the combined Methodist and Evangelical and Reformed efforts to build their hospital facility as part of the Louisville Medical Center. It is a saga that illustrates a tension between political logic and economic logic. In some ways, it was about growth, but to whose economic benefit? For the most part, the growth coalition was able to persuade the Methodist 
Evangelical Hospital (MEH) organization to build the facility downtown in the Medical Center because it could set the community priority.

Initially the Methodists were going to build their own hospital to replace the old Deaconess Hospital that closed in 1951. The German-heritage Evangelical and Reformed denomination, through its "Evangelical Hospital Association," was going to build a new facility in Louisville. They had been unsuccessful in almost 30 years of attempts and continued to be hampered by the anti-German sentiment of post-war years. The Methodist Conference merged efforts with the Evangelical Hospital Association in September 1948 with an eye to replacing the failing Deaconess Hospital. Before the merger, representatives of both denominations were part of the "Special Committee on the Medical Center." As a merged concern, they continued to have financing problems. Furthermore, they aimed to build the proposed hospital on an estate in the southern end of the "Highlands" area of Louisville, which made economic sense for them. The Methodist and Evangelicals won the legal right to build in the Highlands over the objections of local neighbors with a NIMBY ${ }^{123}$ attitude. However, they ended up building downtown, because the growth coalition was able to make it a condition of receiving necessary Hill Burton building funds (Amster and Zingman, 1994, pp.14-29).

\section{Early Funding Struggles}

When they had merged, the Evangelical Hospital Association and Methodist Conferences had pledges from parishioners, but not the money in the bank. Amster and Zingman's history of Methodist Evangelical Hospital repeated several times that progress was stalled due to the slow payment on pledges (Amster and Zingman, 1994, pp.14-23).

\footnotetext{
${ }^{123}$ NIMBY stands for "Not In My Backyard."
} 
Their struggle for adequate matching funding persisted throughout the early planning stages of the Medical Center from 1944 through 1950.

The MEH Plan for the South Highlands and the Opposition

Location was important to the Methodists because the Deaconess Hospital was failing in the late 1940's due to its declining neighborhood. Frank Pfieffer, MEH board member said that the MEH group decided against moving to the Medical Center because it was in the "slums" (Methodists to Delay New Hospital, September 12, 1953). The Methodist Evangelical Hospital planners settled on the property in a residential area that the Methodists had already procured versus property that the Evangelicals had purchased at Preston and Eastern Parkway. The research by the Methodists indicated that the Claggett Estate in the south Highlands of Louisville was an ideal site with the projected growth of the suburban Buechel area and it access to the proposed beltway.

\section{The Community Battle}

Amster and Zingman (1994) noted that a grassroots citizen's group near the Claggett Estate sent out 1000 letters in an effort to preserve the quiet, residential character of the neighborhood. ${ }^{124}$ When the citizens were unsuccessful getting the CityCounty Planning and Zoning Commission to acquiesce, they filed a number of lawsuits that went all the way to the Kentucky Court of Appeals. The MEH group won the Court of Appeals decision. Amster and Zingman reported that the citizens group appealed to the Supreme Court, and the case was thrown out on a technicality (pp.16-17). The neighbors gave up at that point, but a combination of funding and continued political conflict posed a more potent problem.

\footnotetext{
${ }^{124}$ There are several newspaper articles that covered the efforts of the residents. Further discussion of the content does not seem to be relevant here. In this case the hospital history seems to be sufficient to cite.
} 


\section{The Growth Coalition Battle}

The growth coalition came along next and effectively redirected placement of the MEH facility from the old Claggett site. Amster and Zingman (1994) commented that the larger vision of the LADA affected the hospital site decision and Methodist fundraising ability (p. 19). A mitigating factor was that the MEH group was struggling against inflation (p.22), which kept increasing the projected construction costs and impeding efforts time and again. While the inflation was a function of the larger economy, it appeared to enhance the power of the growth machine apparatus to apply pressure on the MEH group to comply with the larger plan.

After another delay in building MEH was announced at the 1953 state Methodist annual meeting, two newspaper editorials serve as a marker that the growth coalition was present and influential. The Louisville Times (A Chance to Reconsider the Site of the Churches' Hospital, 1953, September 26) strongly encouraged the MEH group not to build on the Claggett estate, but to build in the Louisville Medical Center. The editorial was clear that the Times was not making the suggestion on behalf of the polemic residents near the Claggett estate site, but that both the hospital and the medical center would benefit from MEH moving Downtown. The editorial affirmed the tenets of the 1948 Hamilton report that centralization is both efficient and economical, while recognizing that the Hamilton report had not been followed in detail as the medical center had taken shape. The Courier-Journal (Methodist Opportunity, 1953, September 28) wrote that MEH "can also contribute materially to local doctors' dreams of a great medical development here by making their hospital a part of Louisville's' Medical 
Center." 25 These editorials sent the message that the growth coalition wanted MEH downtown in the Medical Center.

In September 1954, Frank Pfeiffer, vice-chair of the board of trustees for the MEH Hospital Association, accused state Methodist officials of playing politics. Pfeiffer said that Governor Wetherby, who happened to be a Methodist, showed more allegiance to his political affiliation than to his religion. The Courier-Journal also cited Pfeiffer as claiming that the MEH group was pressured to move to the medical center site and abandon plans for the Claggett Estate. Furthermore, Pfeiffer alleged that because MEH did not agree to go to the Medical Center site, the Hill-Burton funds were instead given to Jewish Hospital (Delay on Hospital, 1954 September 12.) The growth machine apparatus appeared to convince state officials on a particular course of action. ${ }^{126}$ The Growth Coalition Wins: Hill-Burton Funds Coax MEH Downtown Both Amster and Zingman and available newspaper coverage indicate that no further concrete resolution occurred when MEH acquiesced to put its facility downtown. Amster and Zingman concluded "The pressure to move downtown seemed to be working." Amster and Zingman reported that the MEH group began negotiating with University of Louisville and the Medical Center. Then the Kentucky State Hospital Advisory Commission announced that Hill-Burton funds would be released (p.26). Clark (1955, October 17) reported in The Courier-Journal that MEH was allotted the money because, as a part of the medical center, it would be a teaching hospital and serve the entire state through the University of Louisville Medical School. Clark also wrote,

\footnotetext{
${ }^{125}$ Amster and Zingman erroneously combine the two editorials. They used the title of the Times editorial with the quotation from the Courier-Journal editorial (pp.24-25)
} 
Jefferson County's priority for federal money for general hospital construction is low. But added priority is given a hospital that, in effect, serves the entire state through the Medical School. ${ }^{127} 128$

\section{Late Political Opposition from Doctors: MEH should be in the Highlands}

General practitioners who preferred their east end offices to a MEH downtown location made a rare political statement. The Louisville Times (Doctors Favor East End, 1955, October 4) reported that the Jefferson County Academy of General Practice "unanimously turned thumbs down on the Medical Center plan." The general practitioners did not like the downtown traffic congestion and felt that the Claggett estate location would benefit more patients as well as benefit the doctors themselves. ${ }^{129}$

Amster and Zingman reported that University of Louisville Medical School dean, Murray Kinsman MD, campaigned against the resolution at a meeting of the Jefferson County Medical Society (p.27). Both Amster and Zingman and The Louisville Times reported that the Jefferson County Medical Society (JCMS) took its own mail poll. The Courier-Journal (Downtown Site Given Edge, 1955, November 22) reported that by a small margin the doctors in the JCMS poll preferred the Medical Center site.

In this case, the doctors showed some political preference for convenience on their behalf. It appears that the University of Louisville Medical School dean acted as part of the growth coalition to persuade the doctors to go along with the Medical Center location for MEH.

\footnotetext{
${ }^{126}$ Amster and Zingman recognize this story in their history (pp.25-26)

${ }^{127}$ This story pinpoints that the agreement was reached for MEH to go to the Medical Center in July 1955.

${ }^{128}$ There were some exceptions discussed in this story such as why did Saints Mary and Elizabeth get HillBurton funds in 1954 for the yet-to-be-built facility, during the same time MEH was trying to get HillBurton funds? The answer was that the money was for what was to be a nursing home section of the hospital. (Courier-Journal, October 17, 1955)

${ }_{129}$ The Courier-Journal also ran a story similar to the Times.
} 


\section{Final Relevant Actions and Comments from the Growth Coalition}

The Louisville Times (New Hospital Approved, 1956, June 6) reported that the State of Kentucky Methodist Conference approved the construction of the MEH hospital in the medical center. The Methodist bishop was quoted as having received assurance from then Louisville Mayor Andrew Broddus that the mayor would persuade the Board of Alderman to approve $\$ 400,000$ to acquire the necessary land in the medical center. The Courier-Journal praised the decision the next day in an editorial (Methodist Hospital Assured, 1956, June 7) and called it "cause for congratulation." The editorial strangely discussed Mayor Broddus' reticence about having promised the money and in turn suggested that urban redevelopment funds be used for purchase of the land. Here, the local newspaper was clearly acting as a member of the Louisville growth coalition.

Eventually the University of Louisville and MEH signed the deal for the property on January 15,1958 . It was a 99 -year lease at $\$ 1$ per year. The Courier-Journal (Methodist Hospital Site, 1958, January 16) noted that the actual property was worth $\$ 250,000$ and that the city was going to reimburse the University $\$ 50,000$ per year for five years. ${ }^{130}$ Amster and Zingman reported that "Under the lease MEH need only pay $\$ 1$ a year to provide for two conference rooms, to 'be scheduled by the hospital' for the primary purpose of the medical school" (pp.28-29). Eventually, the hospital opened September 6, 1960 (Amster and Zingman, p.44).

\section{Section Summary}

This section reviewed how the growth coalition in Louisville compelled the dissident Methodist and Evangelical and Reformed hospital organization to build their

\footnotetext{
${ }^{130}$ The actual hospital did not open until 1960 after a number of delays that did not appear to be pertinent to Growth Machine activities.
} 
facility as part of the Louisville Medical Center. It was in the economic logic of MEH to build in the southern Highlands of Louisville on an old estate site where there was expected suburbanization where such a facility would be viable. However, because the growth coalition could act as a de facto gatekeeper of Hill Burton funds, MEH had to build in the Medical Center.

The story illustrates growth machine action in several ways. First, the LADA and not Louisville City Government was the powerful party in deciding where the hospital should go. The LADA was able to convince the State of Kentucky to go along with its view of priorities - which meant St. Marys and Elizabeth Hospital could build outside of the downtown area but not MEH. City government was again on the periphery until the end of the story when it was consulted for what it could bring to the table. The CourierJournal and The Louisville Times outwardly acted as either cheer leaders or statesmen through their editorial pages to help the MEH move to the Louisville Medical Center. While a smaller detail, the University of Louisville was the primary deal-maker at the end. The elements of Molotch's growth machine thesis were in play throughout the story.

\section{Conclusion and Analysis}

This chapter argued that there is a historical continuity in the applicability of the growth machine thesis to healthcare politics in Louisville from 1945 to 1958 . The founding of the Louisville Medical Center and the saga of Methodist Evangelical Hospital were demonstrations of the growth machine thesis in explaining local healthcare politics. The ideas for developing hospital facilities did not come from Louisville City Hall but instead came from the Louisville Area Development Association (LADA). The 
actors as a whole came from within LADA but in the larger sense came from growth coalition sectors, even if they were hospital board members. One can deduce from the records and newspaper coverage that the Louisville City Council and other elected politicians were on the periphery initially and were involved later only when invited to join by the LADA based on what they had to offer to further growth.

The members of the growth coalition could be identified as dominant throughout the story. The special committees were dominated by those with growth-coalition livelihoods. The editorial writers of the Louisville Courier-Journal and Louisville Times were faithful growth coalition members in delivering messages, acting as statesmen, and exhorting MEH to conform to the growth machine goals of developing the Medical Center.

The growth coalition dominated the process from beginning to end. The University of Louisville was a central player in the whole process. Coalition members made the decisions and orchestrated the activity. While it took time for the growth machine apparatus to assemble the necessary people and resources to make the Louisville Medical Center a reality, the growth coalition was able to set up the necessary meetings among vital players both inside and outside the LADA. They were able to facilitate a bond issue for the funding of the laundry and the 1955 steam plant that has continued to supply the hospitals with heat and steam. The cooperation for the medical center's formation and persuasion of MEH took place at the highest levels and left out the general populace except for a bond issue referendum. ${ }^{131}$

\footnotetext{
${ }^{131}$ It was remarkable to find a memo from the LADA Executive Director to the Mayor, the University of Louisville President, and the President of the Board of Alderman discussing what they had been delegated to do in the name of growth!
} 
The growth coalition also demonstrated the ability to negotiate with the next level of government above the city. They used that ability in strong-arming the Methodists and Evangelicals to build their facility in the medical center versus the south Highlands area of Louisville. ${ }^{132}$

The growth coalition demonstrated its limits in two ways. Even with elaborate plans, it failed to convince the federal bureaucracy to change plans for where the VA Hospital should go, therefore limiting its power by the larger structure. The length of time that it took to implement the plan suggests that the growth coalition was limited by the financial state of the relevant organizations in Louisville.

${ }^{132}$ MEH was a general hospital and not a teaching hospital. It had a declining population and merged with Alliant Health System, later Norton Healthcare. It was later closed (Amster and Zinger, 1994, p.85). 


\title{
CHAPTER V
}

\section{HISTORICAL ANALYSIS PART \#2: THE TRAJECTORY OF HEALTHCARE PLANNING IN LOUISVILLE FROM 1966-1983}

\author{
Overview \\ This chapter will examine the historical trajectory from 1966 to 1983 of the now- \\ defunct local health planning organization that went by the names: "Louisville Area \\ Health Facilities Council" (LHFC), "Falls Region Health Council/Kentucky" (FRHC), \\ and "Kentucky Health Systems Agency West" (KHSAW). The Louisville growth \\ machine apparatus/growth coalition started the LHFC under the auspices of the \\ Louisville Area Chamber of Commerce as a planning agenda to further its development \\ agenda. Over the course of the trajectory, the growth machine was forced to turn over \\ healthcare planning to a pluralistic but bureaucratic KHSAW organization that had a \\ totally opposite agenda of healthcare containment. \\ Over the observed time period, the Federal Government imposed increasingly \\ restrictive funding rules upon the local growth machine elites. The restrictions watered \\ down the growth machine influence and agenda and eventually forced them out of local \\ healthcare planning. The growth machine was able to stay in control of healthcare \\ planning and continue its development agenda until 1976 when they were forced to turn \\ over the reins to mostly non-elite consumers. The resulting historical trajectory \\ illuminates the differences between local growth machine control and federal control of
}


Those questions were asked numerous times over the trajectory of healthcare planning in Louisville in every newspaper story, every archival document, and each elite interview.

Asking those questions repeatedly produced a complex picture of dynamic change; over the observed time, local healthcare planning changed in several aspects. The parties in control changed. The scope of the local healthcare planning organization changed, and its agenda changed. The rules tied to the money financing this organization changed. Expressing those changes in a coherent fashion presents a challenge.

Therefore the choice here for parsimoniously demonstrating historical continuity is to create a model that describes the political-economic tenets and use that model as a taxonomy for clarity. Figure 1 presents this model.

\section{Figure 1}

The Areas of Dynamic Change in the LHFC/FRHC/KHSAW Trajectory

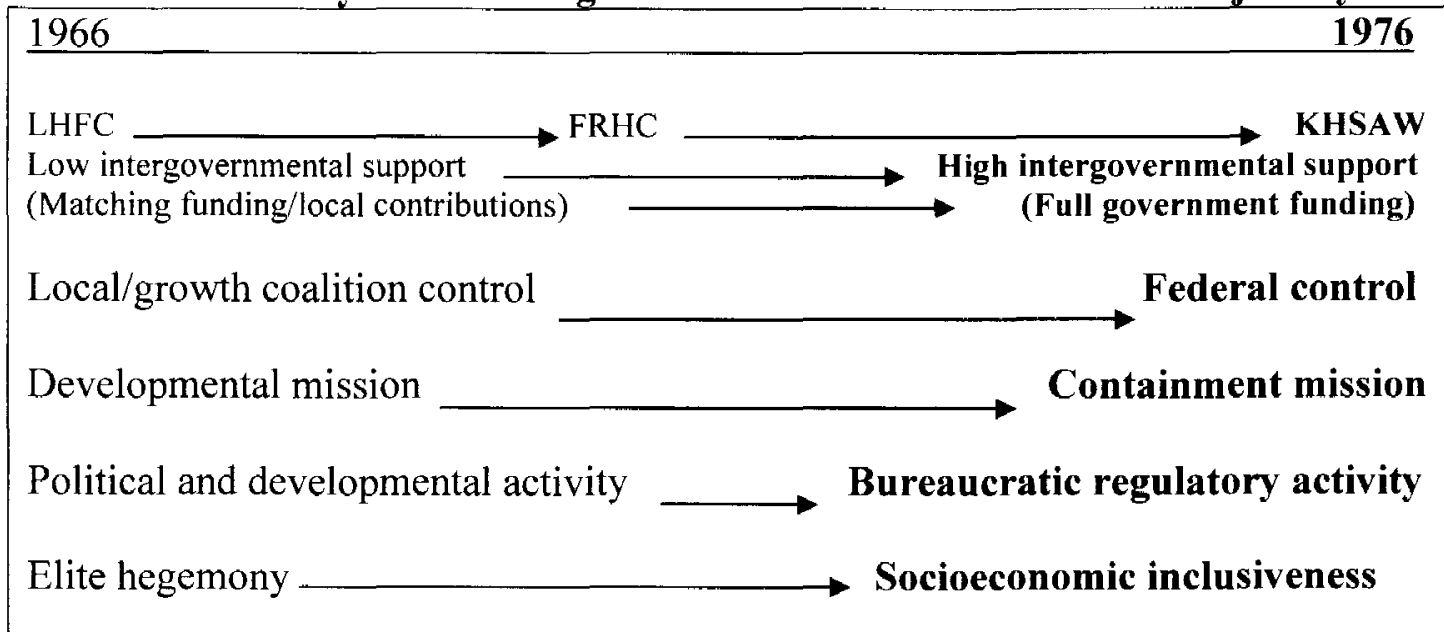

This model presents the complex political-economic phenomena. By taking the review of the different organizational changes separately, we can see growth machine activity. We can also compare it with non-growth machine activity through the observation of dynamic change in the "driving variable" of "intergovernmental support" as defined by Savitch and Kantor (2002) in terms of local control versus federal control. 
For Savitch and Kantor, the two driving variables (in the spirit of driving a car) are "market conditions and intergovernmental support." They purport that "intergovernmental support, provides the finance and infrastructure that are also essential for development" (p.47). ${ }^{133}$ The change in this driving variable provides a contrast between where the growth coalition was in charge and where it was supplanted.

The rest of this section will discuss the changes as depicted in the model through available, historical material. It will first discuss the organization's transition from being an elite organization into a pluralist organization inclusive of the general public. It will then discuss the change from a developmental agenda to the containment agenda and how that change was borne out of the change in intergovernmental support or funding.

Elite Hegemony to Socioeconomic Inclusiveness

This section will discuss the initial elite nature of the healthcare organization. It will then discuss the elite composition of the board and how it was transitioned into a pluralist or inclusive body.

\section{Elite Beginnings}

The Louisville Area Health Facilities Council (LHFC) was organized in private by the elites under the auspices of the Louisville Chamber of Commerce without the knowledge of the general public. The January 22, 1965 meeting of the Louisville Chamber of Commerce Economic Development Committee was the earliest documented

\footnotetext{
${ }^{133}$ Savitch and Kantor proposed a political-economy model of development using a metaphor of driving a car that consists of two driving variables (market conditions and intergovernmental support) and "steering variables" which consist of popular control and the local culture. The different manifestations of development arise from different values of the variables (pp.47-53). Their book is a comparison of development across international boundaries of cities in North America and Europe. They include discussion of how different levels of intergovernmental support are manifest in different countries.
} 
closed meeting about the organization (Louisville Area Chamber of Commerce and Predecessors Records University of Louisville Archives and Records Center).

Elites kept discussions about local healthcare planning to themselves for three years. Handleman (1967) and others on the Jefferson County Medical Society (JCMS) Hospital Committee reported to the whole JCMS that such discussions had been going on since 1963 (p.22). Handleman et al indicated that process took as long as it did because various hospital administrators and trustees wanted time to make their own plan. Handleman et al credited banker Charles Kane and lawyer David Waterman for being persistent in building a consensus and acceptance for the planning council (pp.22-23). The Courier-Journal finally reported in July 1966 that the organization was being put together (Bulleit, 1966, July 29). Given the time frame, this disagreement was in growth machine style as it was obviously was not open to public input.

\section{Initial Elite, Growth Coalition Hegemony}

The majority of LFHC board members were from growth coalition sectors. ${ }^{134}$ Table 3 lists the council members and their livelihoods. The aberration from the growth machine was the presence of individuals from branch plant and chain retail management livelihoods as these types are not part of the growth coalition.

Two months later The Courier-Journal published a second list of additional members (Health Planners to File 1966, September 16). Table 4 lists these additional

134 One of the complications in researching this organization is that there were few surviving archival records, and so getting a detailed roster of the Louisville Area Health Facilities Council was impossible. However, some markers of the growth coalition can be deduced from lists of LHFC members printed in Courier-Journal stories. The only surviving membership rosters are in KHSA-W reports available in the University of Louisville Law Library and the University of Louisville Ekstrom Library. It was by accident that the Lee Hamilton FHRC documents were discovered in the Indiana University archives. 
members. There appeared to be one token doctor on the initial board. The bottom line was that the growth coalition maintained its dominance.

Name

Table $3^{135}$

Initially Published Roster of the LHFC

Charles Kane (first president)

Citizen's Fidelity Bank

W.D. Dance

General Electric

Edward L Diener

Sears

Lewis Hirsch

Local Executive

James F. Gordon

Federal District Judge

David L. Waterman

Lawyer

E.C. Pearson

Funeral Director

Don Giffen

Blue Cross/Blue Shield

Eugene Alvey

Lawyer

Earl Muir

Louisville Trust Co

Paul A Hackney

Architect

James J. Cone

General Electric

J.L. Willenbrink

Retailer

Thomas M. Layton

Unknown

Sister Margaret Vincent

Our Lady of Peace Hospital

Joe M. Rodes

Salesman

\footnotetext{
${ }^{135}$ Sources: (Area health advisory unit 1966, July 29), Caron's Louisville City Directory 1966.

${ }^{136}$ The Method of determining the sectors and roles came in the following manner. First, existing archival documents already possessed and hospital histories were reviewed for any indication of sectors. Second, an obituary search was done using www.ancestry.com for dates of death. The Courier Journal microfilms were accessed, Caron's directories were used last.
} 


\section{Table 4}

Additional LFHC Members

Name

\section{as Identified in Courier-Journal Stories. ${ }^{137}$}

William Kendall

Grant Thomas

G.E. Reimers

Cyrus MacKinnon

Eugene Johnson

Dillman Nash

G.J. Douglas

Dr. N.I. Handleman

Edward S. Bonnie ${ }^{138}$

Robert L. Sloss

Preston B. Joyes Jr.

Samuel Lord

John J. Cross Jr.
Louisville and Nashville Railroad

American Synthetic Rubber Co

International Harvester

Courier-Journal-Louisville Times

Local Restaurateur

Retired Executive

Ford Motor Co

Physician

Lawyer

Lawyer

Local Insurance Executive

E.I. Du Pont de Nemours Co Inc

Citizens Fidelity Bank and Trust Co

\section{Weakening of Growth Machine Hegemony}

In October 1968, The Courier-Journal carried the LFHC's announcement that it

would reorganize. It was to become a planning agency for a nine-county district or region $^{139}$ (Council for 9 counties, 1968, October 11). The reorganization finally came to

${ }^{137}$ (1966, September 16). No byline. Health planners to file incorporation articles. Bulleit, (1968 December 31 ) Group Almost Off the Ground? Health Planning Unit Names Leader" Bulleit (1969, January 31-69) "9-County Health Planning Unit Outlines Organizational Plans, Budget Request."

${ }^{138}$ Bonnie was named later in a story in 1969 as a member, but cited in Dillman Rash's 1967 letter as already a member of the LFHC, which adds to the question as to whether there the listing of members has any implication for whether they were initial members or additions to appease the state?

${ }^{139}$ The region was called "Region 6." 
fruition one year later, and the organization was renamed the Falls Region Health Council (FRHC). The Courier Journal reported

Unlike the Health Facilities Council's board of directors, the new board must follow state and federal guidelines. It must include representation from the poor, school administration, rural areas, pharmacy, health insurance, the Social Security Administration, welfare programs and "areas of minority status group concentration Bulleit (1969, October 1).

During the year it took to reorganize, the FRHC had a quandary due to the Louisville metropolitan area straddling the Kentucky-Indiana state boundary. Were Floyd and Clark Counties in Indiana to be involved in the FRHC as its coverage area was expanded (Bulleit, 1969, January 31), (Ward, 1969, July 1)? The FRHC solved this problem by creating two divisions: a north sub-council for the Indiana counties and a south sub-council for the Kentucky counties (Lee Hamilton Papers).

With the FRHC, there was the initial appearance of some pluralistic input. The Courier-Journal ran a story of the FRHC's invitation to the general public to nominate board members (Public can help name, 1969, November 11).

Despite the token invitation to the public, the growth machine elites continued to dominate. The FRHC named its members in January, 1970 (Board of 35, 1970, January 9) that included members nominated by county judge-executives from outside Jefferson County. ${ }^{140}$ Table 5 lists the members and their known livelihoods. One third of the FRHC members had previously been on the LHFC. However, as the table shows, the Louisville growth coalition hegemony in healthcare planning was weakened by having

\footnotetext{
${ }^{140}$ There were no members from the Indiana counties as they would be named later. It was also evident in several articles and the Lee Hamilton Papers that Robert J. Rossi, who was the editor of the New Albany Tribune, was one of the Indiana members until he relocated out of the area. Even Indiana members were growth coalition members.
} 
board members from both non-growth coalition sectors and from outside Louisville proper and Jefferson County, Kentucky.

\section{Table 5}

\begin{tabular}{|c|c|}
\hline $\begin{array}{l}\text { Initial Members of the Falls } \\
\text { Name and County Representation }\end{array}$ & $\begin{array}{l}\text { on Health Council, January } 1970^{141} \\
\text { Livelihood }\end{array}$ \\
\hline Robert L. Sloss (Jefferson) & Lawyer \\
\hline Cyrus MacKinnon (Jefferson) & Newspaper Executive \\
\hline Dillman Rash (Jefferson) & Business Executive \\
\hline Dr. Walter Hume (Jefferson) & Physician \\
\hline Dr. Douglas Haynes (Jefferson) & Physician \\
\hline Edward S. Bonnie (Jefferson) & Lawyer $^{142}$ \\
\hline Preston Joyes (Jefferson) & Insurance Executive \\
\hline John Cross (Jefferson) & Bank Vice President \\
\hline Homer Coggins (Jefferson) & Hospital Administrator \\
\hline Dr. Samuel Lord (Jefferson) & Corporate Capitalist \\
\hline Joseph Chalfant (Jefferson) & Business Executive \\
\hline Eugene Brewer (Henry) & Business Executive \\
\hline $\begin{array}{l}\text { Sister Marie Victoria- } \\
\text { Fitzsimmons (Jefferson) }\end{array}$ & Hospital Administrator ${ }^{143}$ \\
\hline Donald Smock (Jefferson) & Local Businessman \\
\hline H.Grant Bruton (Jefferson) & Lawyer \\
\hline Dr. John Bishop (Jefferson) & Physician \\
\hline Walter Coe (Jefferson) & Physician \\
\hline David A. Jones (Jefferson) & Hospital Executive \\
\hline
\end{tabular}


(Table 5 Continued)

Don Griffin (Jefferson)

Dr. Thomas Wallace Jr. (Jefferson)

Gordon Dabney (Jefferson)

Des Moines Beard (Jefferson)

Cynthia Rector (Jefferson)

Roy C. Smith (Henry)

Roger Cook (Henry)

George Williamson (Oldham)

Dr. John Froning (Oldham)

Stanley Thompson (Shelby)

Dr. Ronald Waldridge (Shelby)

Imogene Snyder (Spencer)

Lillian Bryant (Spencer)

Clifford Gossom (Trimble)

Dr. Carl Cooper (Trimble)
Insurance Executive

Physician

Business Executive

Non-profit Administrator

Mental Health Professional

Judge ${ }^{144}$

Pharmacist $^{145}$

Lawyer $^{146}$

Physician

Social Worker ${ }^{147}$

Physician

Unknown

Local Businessperson $^{148}$

Business Executive ${ }^{149}$

Physician

Starting in 1970 certain disaffected parties called attention to the fact that they were left out of healthcare politics. One member of the Russell Area Council ${ }^{150}$

\footnotetext{
${ }^{144}$ Personal Communication, Ms. Roy C Smith, August 19, 2007

145 Personal Communication, Ms. Roy C. Smith, August 19, 2007

${ }^{146}$ Graham Troop, Oldham County Historical Society, personal communication August 21, 2007, www.oldhamera.com/articles/2006/08/04/obituaries/obit9.txt

${ }^{147}$ Personal Communication, Stanley Thompson, August 19, 2007

${ }^{148}$ Personal Communication Lillian Bryant, August 19, 2007.

${ }^{149}$ Personal Communication Clifford Gossom, August 19, 2007

${ }^{150}$ The Russell Neighborhood area of Louisville borders at the time of this writing borders the downtown or central business district of Louisville on the west. It has a history of high density of poverty and a high
} 
complained publicly that poor people were not represented on the council and thus did not have a voice. The FRHC response to that complaint was that there were a limited number of seats on the council (Unit chided 1970, May 5).

However, members from the Dixie Valley Hospital Committee, a grassroots organization wanting a hospital in southwest Jefferson County (a working class area), were able to break the ranks of the growth machine apparatus. They lobbied the Jefferson County Fiscal Court in January 1972 to abstain from financially supporting the FRHC until the FRHC appointed members from that area (Hospital boosters 1972, January 16). ${ }^{151}$. The Dixie Valley members were successful as Bulleit (1972, February 18) reported about one month later that seven new members were named to the FRHC that included two southwestern Jefferson County residents and three African Americans. ${ }^{152}$

The key to Dixie Valley Hospital Committee's success was aligning with County Judge (Executive) Todd Hollenbach. ${ }^{153}$ Hollenbach asserted that the FRHC needed to be reorganized as it was unresponsive to community needs (Reihm, 1972, November 23). He claimed the FRHC's having numerous hospital representatives on the board was a conflict of interest (Waddle, 1973, March 29). Hollenbach's primary power was that he was a gatekeeper for local funding that the FRHC needed to get matching federal grants. ${ }^{154}$

concentration of government housing. The protester was excluded from the FRHC because membership was cut from the proposed size of 49 to 35 .

${ }^{151}$ The Fiscal Court was the legislative body of Jefferson County prior to the city-county consolidation of Louisville and Jefferson County in 2003.

${ }^{152}$ The other two new members included a hospital administrator and a public health nurse.

${ }^{153}$ The typical county structure in the Commonwealth of Kentucky is to have a Judge/Judge-Executive as the elected executive or administrator.

${ }^{154}$ Hollenbach had later publicized intentions to sue the FRHC if it did not approve the hospital plans. 
Even with Hollenbach's influence, the growth machine kept the appearance of control of the FRHC. A Courier-Journal story (Runyon, 1976, August 23) reported that Mary Mullins, who was on the Dixie Valley Hospital Committee had been appointed to the FRHC board in fall 1973. The Courier-Journal index did not report such coverage of her appointment in 1973. What was reported in The Courier-Journal (Finley, 1973, June 22) was that the FRHC's vote to reorganize included a significant turnover of members, and that another member of the Dixie Valley Hospital Committee was appointed. Since the daily newspaper is a member of the growth machine apparatus, the conclusion seems fair that the growth coalition did indeed hide the fact that it was losing control between 1973 and 1976.

Supplanting the Elite: the Kentucky Health Systems Agency-West (KHSAW)

In terms of board composition, KHSAW was clearly a pluralist organization from start to finish. It was by federal law that KHSAW was pluralist as members were either consumers or providers. Table 6 shows the 1979 KHSAW Board of directors.

While Jefferson County/Louisville accounted for about one-third of the members, there were no growth coalition members. The only former FRHC members were Mullins and Walter Hume MD. The majority of the members were from outside the Louisville area, and KHSAW had no members from Oldham, Trimble, Shelby, Spencer or Bullitt Counties, which were previously represented on the FRHC.

KHSAW was a consistently pluralist organization in its membership throughout its history. Mullins was actually KHSAW president at the end of that organization's 
existence (KHSAW, Runaway Health Care Costs: Steps toward a Solution, no page number). ${ }^{155}$

Table 6

Name

Kentucky Health Systems Agency West, Board of Directors $1979^{156}$

Robert O Miller Identification

Robert S. Reed

Consumer Marshall County

William Shadoan

Consumer, Ballard County

Larry Brown

Long-Term Care Provider, Hopkins County

A.R. Lasley

Consumer, Christian County

Harold Morgan

Consumer Lyon County

Frank R. Pitzer, MD

Provider, Practicing Physician Christian County

William R. Cavin

Consumer Daviess County

Charles R. Chapman

Provider, Hospital Administrator, Henderson County

Erma Risley

Consumer Daviess County

Rebecca Forrest, R.N.

Provider, Practicing Nurse, Barren County

Wilbur W. Gibson

Consumer, Edmonson County

Wiliam Hourigan

Open Provider, Warren County

Ruben Avila

Consumer, Hardin County

Ramona Clifton O.D.

Open Provider, Nelson County

David F. Johnson

Consumer, Nelson County

Harold Boyer

Próvider, Allied Health Professional, Jefferson County

Walter Bunnell, Jr.

Consumer, Jefferson County

\footnotetext{
${ }^{155}$ Mullins' ascension in many ways appears to be impressive. But overall it is indicative of the difference in power structure that the Federal Government enforced.

156 The definitions of the terms "open provider" and indirect provider was not ascertained.
} 
(Table 6 Continued)

Betty S. Fleischaker

Jeanne B. Frank

William Galvagni

Walter Hume MD

Lucille McClain

Mary Mullins

Darryl T. Owens

Mitchell H. Payne

Theodore Segal, D.M.D

Ashar S. Tullis

Russell B. Wimmer
Provider, Certified HMO Jefferson County

Consumer, Jefferson County

Provider, Hospital Administrator, Jefferson County

Provider, Practicing Physician, Jefferson County

Consumer, Jefferson County

Consumer, Jefferson County

Consumer, Jefferson County

Consumer, Jefferson County

Provider, Practicing Dentist, Jefferson County

Consumer, Jefferson County

Provider, V.A. Hospital, Jefferson County

$\overline{(1979}$ Health Plan p.3)

\section{Section Summary}

This section discussed the trajectory of the composition of the LHFC, FRHC, and KHSAW. The growth machine apparatus/growth coalition dominated overall control of the membership of LHFC and the FRHC even though its domination was thinning at the end.

From 1969 on, the growth machine apparatus was gradually pushed out in response to a mix of pressures, but primarily through the funding stipulations. First, the Federal Government thinned out control by requiring the organization to get board members from a wider geographical area and from different groups of people. Then, one rogue elected politician who was a funding gatekeeper was able to pressure the FRHC to let in people from a working-class part of the metropolitan area. Furthermore, federal 
policy changes requiring broader community membership eventually totally supplanted the community elites from control of local healthcare planning.

In 1966, growth coalition control of healthcare planning in Louisville was at its maximum level in the LFHC. Repeated federal policy revisions starting in 1968 required more and more inclusiveness that diffused growth coalition dominance. The FRHC was somewhat of a chaotic middling between the LHFC and the KHSAW as the growth coalition still held the majority but was forced to let more and more non-elites in by local influence and changes in federal funding rules.

In contrast the KHSAW was a non-elite organization. Only two members from the FRHC were carried over: a consumer and a provider. Members were either identified as providers or consumers. The members were from a large region of Kentucky not just Louisville.

The Agenda Shift from Development to Containment

As part of the model, the healthcare planning agenda changed with the membership composition over the trajectory of the LHFC, FRHC, and KHSAW. The agenda and policy shifts were from a development agenda to a containment agenda. The Federal Government imposed the containment policy on the local level. This section will discuss those shifts in agenda and policy in terms of the different organizations and then offer an analysis of some of the tensions.

\section{The Development Agenda}

On the outset the LFHC and FRHC agendas were about development both in the Louisville Medical Center and in the East End of Louisville. The January 22, 1965 minutes of the "Economic Advisory Committee" of the Louisville Chamber of 
Commerce stated that "The primary interest was in the coordination of planning among area hospitals, the relationship between the Medical Center and the association, and projected operational costs" (Committees A-E 1965-69 Louisville Chamber of Commerce and Predecessor Records, University of Louisville Archives and Records Center). Dillman Rash's fundraising letter of June 9, 1967 to then Jefferson County Judge (Executive) Marlow Cook had the following statement:

... those of us who have been concerned in the development of the Council up to now are thoroughly convinced of (a) the necessity for its activities at the present time and (b) the increasing importance of such activities for a logical, sound and effective development of our health facilities in the future.

(Health Facilities Council, Inc. Record Group 1, Accession 2003-050 Box 44 Louisville

Metro Archives and Records Center). Handleman, in his report about the LHFC to the Jefferson County Medical Society for the year 1967-68 stated:

The purpose for the establishment of areawide health planning, and more specifically, the Health Facilities Council, Inc., is to improve and coordinate health facilities and services and to provide for their orderly and systematic development which would best serve and answer needs (p.43).

The growth machine apparatus was active in the organization of the LHFC and clearly communicated that its purpose was growth.

A number of the newspaper stories reported purpose statements of the organization throughout its different phases. One early Courier Journal story (Health planners, 1966, September 16) reported that the area would have a better chance at getting "Hill Burton" funds if recommendations were made from a planning council and not by individual hospitals and facilities. Another story the next month reported that the Jefferson County Medical Society was advocating that the LHFC study a new proposed 
"Norton University Hospital" that would be a teaching hospital in the Medical Center (Medical society will seek, 1966 , October 16$).{ }^{157}$

The Delay in the Growth Machine Agenda Due to Diener

The second LHFC president was E.L. Diener. He was the General Manager at Sears Roebuck and Co. He had been a resident of Louisville for only six years and he did not last long in the post as he strayed from the growth machine agenda. Diener was quoted in a human interest piece in the Courier Journal:

It's good to grab federal money when you can, but you've got to know where you are going after you get it. As far as I'm concerned, there will be no recommendations for federal support to any new facility here until clear-cut plans are presented for independent financing of operation when federal money runs out.

Diener also said that he was considering putting air pollution on the agenda with planning expanded ambulance services versus additional outlying hospitals (New chief of health unit 1968, January 7). Ten months later, the organization was looking for a new president as Diener had declined a second term as LHFC president (Council for 9 counties, 1968, October 11).

\section{The Return to the Growth Agenda}

In December 1968, Diener was replaced by Attorney Robert L Sloss who got the LFHC back on the growth machine agenda. The Courier-Journal article reported that Sloss had no prior healthcare experience but quoted him as saying "but that may be the best because I have no axe to grind" (Bulleit, 1968, December 31).

With Sloss the LHFC finally began considering hospital construction proposals immediately. The Courier-Journal (Bulleit, 1969, January 22) reported that both Norton

\footnotetext{
${ }^{157}$ That doctors were showing this much initiative in promoting growth was unusual.
} 
and Jewish both proposed new construction (Three years after the first time it was publicized that Norton wanted to build). The story also reported that Louisville General was planning a whole new facility. Two days later (in growth machine style), The Courier-Journal celebrated in an editorial that the LFHC finally began its work (The health council finally, 1969, January 25).

While the news coverage during the remainder of 1969 was more about the LHFC's struggle to meet federal funding requirements, the LHFC was able to have a short-lived but intense development agenda. The Courier-Journal exhorted the LHFC in an editorial to take cues from the University of Louisville Medical School. They cited the medical school dean that the medical center needed 1000 more beds for teaching purposes (Hospital planners must, 1969, February 17). The LHFC appeared to take the cue as it had an intense burst of energy and conducted several meetings during April 1969 focusing on building additional facilities in the medical center and replacing the old Louisville General Hospital. ${ }^{158}$

\section{The Middle Position: Tension between Growth and Allocational Policy}

The middle position or phase was a time where the LFHC and FRHC struggled to stay on a growth agenda. The first disruption occurred while the LHFC had to develop the appearance of being inclusive to satisfy the expectations of the US Department of Health Education and Welfare (HEW) to stay in operation. The FRHC was twice distracted from their focus on growth by the federal and state criteria for the qualification for matching funds. In the name of compliance with new federal policy, the FRHC agenda broadened to items other than hospital facilities. The last apparent disruption in

${ }^{158}$ Bulleit, P. (1969, January 22) 
the growth machine agenda was the local challenge from the Dixie Valley Hospital Committee who had aligned with a local, elected politician. The FRHC's agenda was disrupted almost every year in a seasonal fashion by the difficult federal funding process. This section will discuss the agenda trajectory in chronological order.

\section{Disruption\#1 of the Growth Agenda by the Federal Application Process}

The first disruption of the growth agenda was the LFHC's grant application process for the transition into the Falls Region Health Council (FRHC). The grant was tied to the regional membership composition requirement to include members outside of Jefferson County. The Courier-Journal reported that if the next application for operating money was approved, the council would 'assume responsibility for planning and developing a system for delivery of health services to the population of the entire region" (Area Health Planning 1969, February 6). Another story later in the year (Ward, 1969, July 1) gave a different summary statement of purpose for the LFHC

The purpose of the council is to serve as a clearinghouse for requests for federal health facilities funds, including money for waste disposal and water supplies as well as hospitals and medical care.

The official agenda was changed from bricks and mortar to developing a service delivery system; thus the purpose changed from local development to public health concerns.

The activity in this stage was reflective of the tension between the local push to build new hospital facilities and whether those facilities and additional beds were unnecessary. Projects approved after the new Children's and Norton Hospital between March 1969 and 1973 were approved only after intense debate to establish the required consensus. 
While it moved along with plans to replace the dilapidated Louisville General Hospital, the LHFC spent the remainder of 1969 focused on funding matters. The LHFC was stuck waiting on the Federal Government to approve its grant so it could transition into the FRHC. It reorganized the membership of the organization to bring it in to the appearance of compliance. ${ }^{159}$ The FRHC was able to resume developmental activity in May, 1970.

\section{A Small Window of Developmental Activity}

The FRHC had a small window of opportunity to approve more growth before getting stuck waiting for the next federal grant approval. The FRHC approved more beds in the Louisville Medical Center, which was in keeping with the prior agenda suggested by The Courier-Journal editorial. However the growth coalition motivated a shift of priority to the "East End" $" 160$ of Louisville.

From May to September 1970, the FRHC approved three major construction projects. It approved Jewish Hospital's application for 152 beds in the Medical Center that it had rejected the year before (Council approves Jewish Hospital's plans, 1970, May 15). The FRHC ended this run with a dramatic one-month long saga from August to September 1970 over whether to approve two large hospitals in the upscale Louisville suburb of St Matthews, Kentucky. ${ }^{161}$

\footnotetext{
${ }^{159}$ Rejection of Louisville health grant suggested. (1969, May 21 ). Must reapply for U.S. Funds (1969, May 27, ) Bulleit.P. (1969, August 8) To study needs . . council urged to freeze new health projects (1969, August 16) Unless application approved soon ... council faces financial pinch. (1969, September 12)

${ }^{160}$ While this explanation risks over-simplification, in Louisville the primary sections are colloquially known as the East End, the South End, the West End and "Indiana." The East End generally consists of the more wealthy and middle-class suburbanites. The South-End is the working class section. The West End is considered the impoverished, dangerous, and predominantly African-American section. The Indiana section does not particularly carry any one socioeconomic label, although it is considered to be cheaper to live in that section due to housing values.

${ }^{161}$ There was an absence of FRHC coverage in the Courier-Journal from May to August, 1970.
} 
The two St. Matthews hospitals were proposed by the Kentucky Baptists and by the for-profit Extendicare (later Humana) corporation. Both entities had members on the FRHC: Homer Coggins and David A. Jones. The Baptists announced that the old facility in Louisville proper was becoming obsolete, and they wanted to build a new facility and convert the old facility to one for "less than acute care." A FRHC committee had determined through the use of federal ${ }^{162}$ formulas that only 133 beds would be needed in the Louisville region by 1975 and both the proposed 230 bed Baptist facility and the proposed 380 bed Extendicare facility were unnecessary (Bulleit, 1970, August 14).

The Courier-Journal ran a pro-growth editorial two days later. The editorial supported the parts of the Baptist proposal that included a provision for self-care beds. The editorial praised self-care hospital beds as a "good vehicle" for reducing healthcare costs (Hospital beds \& the move to efficient care, 1970, August 16). The newspaper found a way to tout growth.

At the next FRHC meeting covered by The Courier Journal, David A. Jones, ${ }^{163}$ a co-founder of Extendicare, and a FRHC board member took an aggressive stance in challenging the numbers. He asserted that the FHRC committee overstated the bed count in the area by 290 . He also presented a report created by his firm that did the following:

- It forecasted a need of 1,089 beds in Louisville.

- It had survey results of 237 physicians in the area supporting more hospital construction,

\footnotetext{
${ }^{162}$ These formulas were Hill Burton and U.S. Public Service formulas.

${ }^{163}$ Jones was the co-founder of Extendicare with the late-Wendell Cherry. Extendicare changed its name to Humana. Humana became an aggressive builder and buyer of hospitals. Humana became one of Louisville's largest corporations, and Jones has been regarded as one of Louisville's most influential and powerful individuals, if not the most influential one at times.
} 
- It had survey results of the JCMS supporting more hospital construction. (More beds unnecessary, 1970, August 28).

The Courier-Journal (Bulleit, 1970, September 1) reported four days later that the FRHC met again and unanimously approved the two hospitals. This meeting included an appearance by the mayor of St. Matthews supporting the hospitals and giving testimony that he had heard from physicians that the two hospitals were needed. The story also reported that a "reassessment several days ago revised the bed needs figure upward between 289 and 737 based on a patient occupancy rate of 80 percent."

It is ironic that The Courier-Journal ran another editorial five days later eschewing the idea of the minimal care hospital bed (Old ways of health care inadequate 1970, September 6) that it had espoused weeks earlier. The September editorial espoused preventative care like that of the Kaiser Permanente system. The Courier-Journal editorial was critical of the substance of the decisions earlier in the week, but did not disagree with the FRHC decision to approve growth.

Almost as an aftershock to the approval of growth, the FRHC suddenly became restrictive. The Courier Journal (Bulleit, 1970, November, 25) reported that the FRHC rejected the Baptist proposal to continue running its old facility in Louisville proper as an acute care facility when its new St. Matthews facility was completed. The FHRC reserved the right to determine community need when the new Baptist facility was completed. The story reports that only the Baptist executives present were the ones who protested. Baptist Hospital officials tried to push for more growth but were stopped. 


\section{Second Disruption of the Development Agenda}

It was almost another year before the FRHC could look at more hospital construction proposals, because it was stuck in the grant application process and faced extinction. Intergovernmental confusion and contradictory directions from state and federal agencies complicated this matter. The end consequence of the financial crisis was that the FRHC was downsized.

There was little coverage of this complex matter in the Courier-Journal. Bulleit (1971, February 3) reported that after following the suggestion of the Kentucky state program development administrator, the FRHC voted to revise the application to leave out ties with Indiana in an effort to keep hope alive for federal funds to pay staff.

The papers of former Congressman Lee Hamilton ( $9^{\text {th }}$ District Indiana) archived by Indiana University, provide some insight as to the convoluted and complex nature of the funding problem. ${ }^{164}$ Part of the problem was related to the growth agenda characteristic of the FRHC. In a letter dated April 22, 1971, FRHC President Robert Sloss appealed to Hamilton "to bear whatever influences you may" to allow the FRHC to continue (Sloss Personal Communication April 22, 1971 Lee Hamilton Papers).

Attached to Sloss' letter to Hamilton was an informational memorandum that gave the FRHC perspective. The FRHC application had to have numerous official local and state endorsements. For the FRHC to have gotten the Kentucky Health Planning Commission endorsement, state officials in Frankfort stipulated that the Indiana counties had to be "distinguished as a separate component, with separate voting restrictions." The Kentucky Health Planning Commission's endorsement was received on February 28,

\footnotetext{
${ }^{164}$ The Lee Hamilton papers were a late discovery and have provided the only known copies of official FRHC letters and one brochure. There were no internal documents such as minutes.
} 
1971. The memo said that about one week later (March 8, 1971) Kentucky officials had added the requirement that the FRHC get "an unqualified approval from the Falls of Ohio Metropolitan Council of Governments (COG), specified as the local governmental clearinghouse, B.O.B A-95." The state also said that the FRHC had to address the problem of local matching funds.

On March 20, 1971, the FRHC received a different letter from the Kentucky Health Planning Commission saying that the application was being returned for the same two problems (no COG endorsement and local, matching funding). In turn, the informational memo notes that Hamilton's staff was able to ascertain that the HEW had "withdrawn the application from this federal funding cycle" because ""While Indiana had approved the application, Kentucky did not"' (FRHC memo-unspecified date and unspecified author, Lee Hamilton Papers).

Hamilton's file had a clipping of a news story published in the New Albany Tribune (Lay, 1971, March 23) which covered a meeting of the Metropolitan Council of Governments $(\mathrm{COG})^{165}$ at which Robert Sloss and Dillman Rash made an appearance to solicit COG's endorsement. The story reported the opinion of the COG officials that the FRHC would be wastefully duplicating work of the municipalities. Rash and Sloss agreed to revise the application ${ }^{166}$ so it would be acceptable to the COG for endorsement. The FRHC members appeared to make good faith effort to satisfy federal terms.

Records show that Hamilton and his staff made inquiry to the HEW about the problem. A three-page response dated May 3, 1971 from Emil E. Palmquist MD, MPH,

\footnotetext{
${ }^{165}$ Relatively little information is available about the COG other than it appeared to be an A-95 intergovernmental agency. Vogel and Harrigan (2007) define a COG as a voluntary association of local municipalities and counties that join forces to address regional problems. They also held a clearinghouse function for federal grants (p.306).
} 
Regional Health Director of the Atlanta HEW office to Hamilton gave what appeared to be the most comprehensive laundry list of reasons why the FRHC funding application was denied $^{167}$

- The FHRC's application "did not reflect an organization nor an operation that would lend itself to comprehensive health planning for the recognized planning area."

- The FRHC had an "apparent lack of any decision-making authority."

- There was a "Falls Region South" making decisions for Kentucky and a "Falls Region North" making decisions for Indiana. ${ }^{168}$

- The submitted copies of letters of support did not "indicate a broad base of community support."

- "Council membership does not appear to broadly represent the planning area."

- "Letters of commitment or intent to commit funds are missing."

- "Work program seems to be oriented toward categorical programs and in particular, facilities."

Palmquist's other complaints included that the FRHC Board could achieve a quorum without any Indiana members present, and that only two of the possible seven Indiana counties in the region had active participation, and that there was no specification for consumer membership (Palmquist, personal communication 1971, May 3 Lee Hamilton Papers).

\footnotetext{
${ }^{166}$ FRHC would stick to healthcare and avoid subjects like wastewater treatment.

${ }^{167}$ Palmquist wrote a letter to Donald Faigle, then FRHC Executive Director with a letter citing reasons \#2 and $\# 3$ and that reason number $\# 3$ was in violation of a set of regulations called " 314 (b) guidelines that said the applicant must be a single applicant. The implication was that with an Indiana unit and a Kentucky unit, the FRHC was really two organizations.

${ }^{168}$ Neither the Courier-Journal nor the Louisville Times ever noted the sub-divisions.
} 
From the archived papers, it is evident that Hamilton did not provide financial relief to the FRHC. He advised Sloss in a letter dated April 28, 1971, to contact his Kentucky congressman to get support from the Kentucky Health Department. Hamilton also sent Robert Rossi (an Indiana FRHC member and newspaper editor) a copy of the Palmquist letter cited above (Lee Hamilton Congressional Papers). At best, Hamilton provided marginally helpful information.

The Courier-Journal avowed its support of the FRHC in an editorial. The editorial extolled the virtues of the FRHC and indirectly exhorted the community to give financial support to the FRHC (Area Health Planning Hangs in the Balance 1971, April $18)$.

The Kentucky State Health Planning Commission offered to provide staff and office space (but no money) to keep the FRHC in operation until federal funds were available. FRHC Executive Director Donald Faigle told The Courier-Journal that federal money had been withheld pending evidence of financial support from local governments. At the time of the state's offer of assistance, the FRHC had only $\$ 363$ in funds, and the only two full-time staff members left were Faigle and his secretary (State to Bail Out Falls Region Council 1971, May 5). There was no apparent news coverage of any other financial bailout of the FRHC.

There were no further documents or news coverage reporting how this crisis was resolved. It can be concluded that because The Courier-Journal reported the next activity in August 1971, the grant eventually was approved and the FRHC continued operations. 


\section{Conflict within the Growth Machine: Southwest Hospital}

The next episode of growth was one of conflict among the growth coalition members that started in August 1971. The Courier-Journal reported that a Florida-based proprietary hospital corporation was interested in constructing a hospital in the southwest section of Jefferson County. One of the conditions to build it was for some of the existing hospitals to relinquish 125-167 acute care beds (Rutherford, 1971, August 31). The Courier-Journal (Southwest Jefferson County May Get hospital, 1971 November 19) reported that the issue finally made it in front of the FRHC three months later. The story reported that FRHC President Robert Sloss asked for a detailed report and then asked for 60 days to review the proposal.

Compared to the one-month-time frame it took to get the two St. Matthews hospitals approved, it took four years for the working class southwest part of suburban Louisville to get its own hospital. It happened as a function of the gradual erosion of the elite dominance and the power to determine and fulfill health needs for the community.

A group of non-elites wanted a hospital in the southwest portion of the county where the elites did not live. However, the FRHC was protecting the Louisville Medical Center, especially the plans to replace the deteriorating Louisville General. The conflict that ensued was also a process that led to growth elites reluctantly acceded as non-elites from the Dixie Valley Hospital Committee were able to align with County Judge Todd Hollenbach and get a bargaining position at the table.

The Courier-Journal and The Louisville Times ran editorials supporting hospital construction in the southwest part of the county. Reporter Wayne Welch authored the first editorial (Welch, 1971 December 14) and complained about the FRHC's 
indecisiveness and criticized the FRHC for approving two hospitals in St. Matthews while stalling on the hospital for the southwest. The Courier-Journal ran a similar editorial five days later (Medical care $\&$ a faltering planning council, 1971 December 19) that cited Welch's editorial five days before. The Courier-Journal's editorial noted how obtuse it was for the FRHC to approve two hospitals for St. Matthews but was stalling on the hospital for southwest Jefferson County. Again, the local newspaper as a member of the growth coalition was advocating for growth.

The next month The Courier-Journal (Southwest Hospital \& Our Lack of Plan 1972, January 16) ran a detailed, analytical editorial, which cited a meeting not covered by the paper itself. It analyzed the side of the grassroots Dixie Valley Hospital Association. It also analyzed the side of the resistant FRHC members. The story made an interesting conclusion that lends support to the growth machine thesis

What both sides must concede is that the community can't go on tolerating uncoordinated, fumbling health planning, unless it is prepared to go back to the laissez -faire days when doctors, administrators, and perhaps a banker or two made all the decisions in the health facilities field.

This editorial appears to put the paper in a statesman role. While wanting equality, the newspaper recognized the elite nature of the decision and who was involved. ${ }^{169}$

Growth Interlude: Non-growth Items Make the FRHC Agenda

In the process of the battle over a hospital for the southwest, the FRHC finally considered in March 1972 agenda items that were not about hospital construction. The Courier-Journal reported that the FRHC heard proposals that were not for hospitals (For

\footnotetext{
${ }^{169}$ This was at the same time that the Dixie Valley group went to the Fiscal Court asking it to press the FRHC to nominate members from southwest Jefferson County.
} 
falls region area 1972, March 24). ${ }^{170}$ The FRHC approved several family health centers (2 Family Healthcare Proposals 1972, May 10) and family planning applications (Council Supports Extension, 1972 June 8). A particularly interesting occurrence of this period was that the FRHC rejected an application by the City of Louisville for an emergency medical services system - the reason was that it was not regional enough and did not include the FRHC (Region to Seek Emergency Planning Funds 1972, July 20). These projects suggest that the FRHC was acquiescing to HEW expectations of a broader policy scope. The Courier Journal stories indicated that for the duration of its operational life, the FRHC considered more non-hospital applications, especially since a moratorium on new hospital beds had come into effect.

\section{The Southwest Interests Persisted}

Despite the broadened agenda to items other than hospitals, there was persistence on the part of the grassroots leaders from the southwest part of Jefferson County to get a hospital for their area. In the above-referenced May 1972 story 23 additional beds were approved for the new Baptist hospital in St. Matthews (as long as 23 beds were cut from the old Baptist hospital). The Reverend Sloan Lister showed that he was not co-opted just because he was appointed to the FRHC. As part of casting his "No" vote on further expansion of the new Baptist hospital, he stated that he wanted those beds for the southwest part of the county. In the same story, the paper disclosed that there was a moratorium on new hospital beds; something not disclosed before in any prior coverage on the FRHC. In the June 1972 meeting, The Courier-Journal (Council Supports Extension, 1972 June 8) reported that the FRHC was conducting a survey of health needs

\footnotetext{
${ }^{170}$ The disclaimer is made that there may have been other non-hospital facilities that the FRHC considered, but did not get newspaper coverage. It is important to note again that this account is dependent mostly on
} 
in the southwestern part of Jefferson County. The advocates for a hospital in Southwest Jefferson County got a break when Jefferson County Judge (Executive) ${ }^{171}$ Todd

Hollenbach started to act on their behalf publicly in November 1972.

Hollenbach commissioned a study from the University of Louisville Urban

Studies Center (later Institute) that was critical of the FRHC's conclusion against a

hospital in Southwest Jefferson County ${ }^{172}$ (Waddle, 1973, March 29). His last effort was

a threat to file suit against the FRHC if it did not approve a hospital for Southwest

Jefferson County (Rutherford, 1974, January 25).

Despite Hollenbach's pressure, the FRHC failed to persuade other area hospitals to give up beds for southwest Jefferson County (Finley, 1973 June 22). Mason Rudd, ${ }^{173}$ a member of the Louisville-Jefferson County Board of Health, which ran Louisville General, rebuffed the FRHC and said Louisville General was too full and was using all its beds (Rutherford, 1974, January 15).

The Growth Machine Makes a Deal with the State of Kentucky

However, the FRHC was able to make a deal that staved off Hollenbach's legal threats. Next the FRHC approved a plan 10 days later that asked the Kentucky State Comprehensive Health Council "to designate half of Louisville General Hospital's 317

\footnotetext{
newspaper coverage.

${ }^{171}$ This position was first called County Judge and then County-Judge Executive. Prior to city-county consolidation in 2003, it was the top elected administrative post in Jefferson County Kentucky.

${ }^{172}$ This report is in the University of Louisville Archives and Records Center in a folder of Urban Studies Center materials. The Urban Studies Center report was an analysis of the FRHC's study. This committee recommended against the hospital. The Urban Studies analysts evaluated the FRHC's research methods and concluded that the FRHC more or less conducted research to support its existing stance against a "Southwest Hospital." (Assessing health service needs in southwest Jefferson County, Center for Urban and Economic Research folder University of Louisville University Archives and Records Center.)

${ }^{173}$ Mason Rudd has been a prominent and influential figure in Louisville Healthcare for more than 40 years. He has been on numerous boards including the Louisville-Jefferson County Board of Health, Jewish Hospital, and University Hospital. His philanthropy led to a 15-story building on the Jewish Hospital Campus in the Medical Center that bears his name.
} 
beds as special purpose beds, and to de-license 36 pediatric beds at General" and make allowance for the southwest hospital (Rutherford, 1974, January 25). ${ }^{174}$

The State Comprehensive Health Planning Council went along with the FRHC proposal and approved the new Southwest Hospital about one month later (Rutherford, 1974, February 28).

The state agreed to reclassify the 380 beds at the new University of Louisville regional teaching hospital to be special purpose beds and the beds at that hospital would not be counted towards the total number of acute care beds in the region. For the lack of media coverage, it can only be concluded that there were most likely private conversations among elites in Louisville with politicians in Frankfort to effect this change. The non-elites won approval for their hospital in the southwest corner of Jefferson County after four years of trying through a technicality, while the growth coalition protected its interests in the Louisville Medical Center.

\section{FRHC's Final Chapter of Staid Activity}

After the Southwest Jefferson County Hospital saga had ended, the remainder of the FHRC agenda as covered by The Courier Journal and The Louisville Times was more staid. The most heated issue the FRHC dealt with during the last two years of its existence was abortion clinics where a public meeting was emotionally charged (Runyon 1976 May, 14).

There were three FRHC actions pertaining to hospitals that were expansionrelated: 1) approval of a new St. Joseph Infirmary facility now owned by Humana

\footnotetext{
${ }^{174}$ In the 1974 , January 15 story by Rutherford, Rudd had made the first observed comment about the special purpose bed option as the University of Kentucky Chandler Medical Center in Lexington had received this designation.
} 
(Runyon, 1976, January 16) ${ }^{175}$ 2) de-certification of 82 beds from two closed hospitals, and 3) a three-floor expansion of Jewish Hospital for office space, cafeteria space, and expanded room for radiology and nuclear medicine (Runyon, 1976, September 17). ${ }^{176}$ Hume, Brewer and VonderHarr wrote in the annual report of the JCMS for 1974-1975 and summed up the agenda and tension of growth versus regulation witnessed in the FRHC.

At the present time the outlook for anyone trying to achieve new additional hospital beds in this community is essentially nil. According to the accepted 'bed formula' we have all the acute beds we need, and almost all the intermediate care beds necessary. There are some openings for personal homes and mini homes still. The basic problem with the Falls Region Health Council is that it has been subject to the usual Federal directives (which contradict one another and come out with alarming frequency) and it has also been underfunded. It is now up for grabs in this state as to whether we will have one or three planning regions (p.48).

The Agenda of the KHSAW (1976-1983)

The Kentucky Health Systems Agency-West (KHSAW) drew no attention from The Courier-Journal as to its activities. Like the LFHC and FRHC, there were few consistent sources of information about KHSAW. The only relatively consistent longitudinal sources of information about this organization's activities were from the comments in the JCMS annual reports from 1976 through 1980.

The overall perspective of the JCMS reports was that the KHSAW and its Falls Area sub-council were increasingly micromanaging the hospitals over time. Hume (1978) reported that the KHSAW approved a CAT scanner for St. Joseph Infirmary after two years of deliberation, and that recreational facilities for Our Lady of Peace Hospital were stuck in a revision process. In 1980 Hume lamented:

Kentucky Health Systems-Agency West as presently constituted, is engaged in

\footnotetext{
${ }^{175}$ This was eventually known as Humana Audubon and as of this time Norton Audubon.

${ }^{176}$ This was at the very last official meeting of the FRHC before it went out of existence.
} 
drafting and adopting increasingly restrictive regulations for health facilities and services in this area. There is little interest in physician opinion, and there seems to be little concern about patient needs other than economic ones. 'A partnership for Health,' as outlined in the planning law seems unlikely (p.18).

Tillett (1980), in the same JCMS annual report gave an adjunctive report on the Falls

Region Sub-Area Council of KHSAW.

We must report along with Dr. Hume that the Board members and activities of health planning (have) become more intense and federally regulated each year. More and more criteria are handed down from above which is required by the local board in order to maintain their funding. The entire emphasis of health planning seems to be pointed toward cost control (p.18).

Hume took a parting shot in the last indexed Courier-Journal article pertaining to KHSAW (Peirce, 1981, May 26). Hume said pertaining to local health planning: "It was captured by a bunch of militant consumers who said, 'Now's our chance to sock it to the profession."”

A late contribution to this research was from the aforementioned Mary Mullins.

In September 2007 she provided a folder of several KHSAW documents. ${ }^{177}$ One document, The Foundation for a Better Health Care System was a retrospective report of KHSAW activities over its nearly six-year history. This document listed past KHSAW activities in the areas of health promotion, family planning, long term care, hypertension needs, health education, primary care, mental health, and cost-containment. Only one bullet-point of its accomplishments refers to Louisville hospitals (The Foundation for a Better Health System, p.3). Furthermore, KHSAW published numerous publications on various topics including on public health issues and other research results. One other useful document supplied by Mullins at this time is the 1977-1978 KHSAW Annual

\footnotetext{
${ }^{177}$ The document along with several other documents was provided by Mary Mullins. The documents that Mullins provided will be turned over to the University of Louisville Archives and Records Center for preservation.
} 
Report. The Annual report noted that KHSAW received a total of $\$ 1,015,699$ in federal and state funds for the period of 1977-1978 - this was substantially in and of itself a larger budget than FHRC or LHRC ever had (p.18). ${ }^{178}$ The KHSAW had readily acquired the funding from government to carry out this diverse agenda that had nothing to do with economic development compared to the matching funds solicitation LHFC and FRHC had to accomplish for the economic development efforts.

\section{Section Summary}

This section traced the trajectory of the agendas of the three local health-planning organizations (LFHC, FRHC, and KHSAW) in the Louisville Metropolitan Area from 1966 through 1983. Over that time period the agenda evolved from being developmental in nature to one of containment.

From the beginning, the LFHC agenda was solely developmental in that the LFHC was a growth machine vehicle to draw down federal Hill-Burton funds for hospital construction in the city of Louisville. When federal regulations were changed, the organization and its agenda had to change again and again to get the federal funding.

The local organization had a middling stage in where it was required to broaden its responsibility both in terms of spatial dimension and health policy. This middling stage saw the local organization subjected to the increasing rigid funding stipulations. The increasingly rigid state and federal expectations arising out of the stipulations gave other local political bodies such as the Council of Governments the impression that the FRHC was going to unnecessarily duplicate services of other local bodies. As a result of the tension, the LRHC and later the FHRC had almost closed several times.

\footnotetext{
${ }^{178}$ The papers Mullins supplied included two annual reports, 1977-1978 and 1978-1979. The 1978-79 annual report noted that KHSAW had $\$ 1,174,332$ in state and federal grants.
} 
The last agenda phase of the local organization was the KHSAW which was a bureaucratic, regional agency. The KHSAW did the Federal Government's bidding to attempt to contain healthcare expenses. As a result, the organization was micromanaging the hospitals in areas of equipment and services, instead of solely bricks and mortar. Per the reporting physicians in the JCMS annual reports, the KHSAW was in turn subjected to increasing federal regulations each year.

\section{Available Information from Field Interviews about the LFHC/FRHC Agenda ${ }^{179}$}

Several informants with high Bonacich centrality scores (discussed in the next chapter) had direct experience with the LFHC, and FRHC but not the KHSAW. ${ }^{180}$ Supplemental questions were asked of these informants about these agencies in the course of the interviews. The goal was to gain additional insight into the politics, processes, and outcomes of the FRHC and LFHC activities.

\section{Reliability of Information}

The overall problem with soliciting oral history in this case was 30 to 40 years had passed, and that the informants gave general conclusions about the overall circumstances. The informants had difficulty remembering details.

As elicited from the informants, many of the elite members of the LFHC and FRHC who were either named or who had joined the local organizations had a "smart growth" $" 181$ versus a plain growth mentality. One of the informants cited that a consequence of the over-building led to high hospital bed vacancy rates in the 1980s.'

\footnotetext{
${ }^{179}$ The answers of the informants have been written in a way to protect identities. Actual quotes were used when they appeared that they would not give indication to an identity.

${ }^{180}$ One interviewee had disclosed being part of the KHSAW but offered no anecdotal material.
} 
Perspectives on the Overall Agenda of the LHFC and FRHC

With regard to observations about the agenda, two informants said that growth was a prime purpose in the politics of the LHFC and FRHC. One informant said that he learned the hard way about the FRHC as "I thought it was a sound structure to provide superior healthcare at reasonable cost. And that I discovered was that we were essentially talking about bricks and mortar."

The informants suggested that there was a tension between political logic and economic logic in the politics of the LFHC and FRHC. Some informants said that there was conflict among the LFHC and FRHC board members about focus. Some were concerned about over-building so as to keep the overall cost of healthcare under control, while others wanted to build and had the political and economic resources to further the growth agenda.

One informant's opinion was that the hospital organizations in Louisville wanted the market to be the guide as they were both "very market-minded and financial-minded." Humana drove the market in 1970 with its aggressive expansion agenda. The rest of the hospitals followed suit and also put pressure on the FRHC to allow them to expand.

\section{Perspectives on Political Power}

In terms of the overall political retrospective about the FRHC, it was started with good intentions. One informant said he participated as he thought it would be a

... well-meaning attempt, and having a forum in which to discuss community needs I think is always a good idea. I don't think they had a major impact, but I think that those kinds of activities do help sometimes to shape what happens in a community.

${ }^{181}$ Diener was an example of this as cited earlier in this chapter. "Smart Growth" usually refers to an ecologically friendly form of city development so as to control urban sprawl. 
Another informant suggested that underlying economic competition among members that led to its downfall.

I remember they were trying to get more political clout. They were going to look like one entity of institutions ... members or who did not necessarily have the same objectives or are competing with one another. It just kind of flopped.

Therefore, with regard to political terms, the FRHC organizational structure was flawed.

Another informant said that the funding patterns based upon local voluntary contributions were major problems in the organization's functioning. The FRHC did not have the power to impose a tax, and the only money available was from city and county budgets. The FRHC was supposed to be funded by the very organizations it was supposed to regulate which meant, "governing with a tin cup." A surgeon making lots of money and making political contributions "would be listened to much more than people who represent these amorphous consumers."

The political pressure from the elite on the FRHC was not only through the lack of funding, but also interpersonal. One informant who had been a FRHC member said that he even had pressure from friends on hospital boards questioning his personal intentions given his actions and positions.

\section{The Politics of the St. Matthews Hospitals}

The financing flaw was a significant factor in how the FRHC approved hospitals under political pressure. The more adept and better-financed members of the elite who could interact more effectively with the State of Kentucky than the FRHC could thus advance their growth agenda. This was evident in the FRHC's approval of the two hospitals for St. Matthews. 
Two informants expressed opinion on this political and economic dynamic. One

informant said:

This a non-supported deduction on my part, but I think (David A.) Jones understood the politics of local and state and federal better than the traditional so -called nonprofit hospitals. And he was able to get legislation and he had the local content or he and (Wendell) Cherry did. And (they) had the chutzpah. Baptist was always playing a catch up game that started with the old act (Hill -Burton money) they saw themselves out -maneuvered at every turn, so if you can't beat them join them, and they joined the process. They took advantage of the ground breaking that Jones and Cherry were able to pull off.

A second informant felt that Jones and his Humana Corporation had the resources, lawyers, and accountants to overwhelm the FRHC's limited staff. The Humana group had the information and analysis to persuade or assert that the ratio of beds should have been changed from 1:1000 to 1:700 of population. The St. Matthews Hospitals were built on this premise. ${ }^{182}$

\footnotetext{
${ }^{182}$ It bears to compare that the material about the LFHC and the FRHC seems to be consistent with the findings of Morone (1982) whose dissertation studied the health systems agencies (HSAs) as created by the 1974 federal Act. Morone noted that "The HSAs were caught in a fragile political equilibrium. Surrounded by hostile actors, they constantly faced extinction." In the local case there were an increasing number of strings tied to federal funding and both the LHFC and FRHC got entangled and dragged away as those strings pulled the organization farther and farther from the growth agenda of the community elites. Even though this organization arose from the elite, it presented more or less as an unprofessional or amateur enterprise and such an estate complicated its lack of funding from local sources. This amateur status complicated its financial problems. It lacked the talent that would otherwise compensate for a lack of resources. This makes sense in light of one of the informant's comments about how Extendicare/Humana with its greater resources out-maneuvered the FRHC politically in getting its hospital in the suburb of St. Matthews approved. Even though Morone wrote in general about the later HSA's, his statement applies here: "Like many amateur enterprises it is slow, inefficient, marked by ignorance and often apathy (at times even achieving a quorum can be an achievement)" (p.11).

A memo from Agnes Livingood (1973) (an Urban Studies Center employee) to Doug Nunn (the Urban Studies Center director) sheds further light upon the operational difficulties of the FRHC. She reported to Nunn that the FRHC had problems getting their work done in a timely manner--especially reports for council consideration. She noted that the FRHC could not attract the public to come to an open forum. She also noted the FRHC board had difficulty in maintaining clarity and purpose in their meetings (Livingood, Personal Communication June 8, 1973 Center for Urban and Economic Research University Archives and Records Center University of Louisville).
} 


\section{The Politics of Southwest Hospital}

Two informants had answers on the dichotomy between the quick approvals for the St. Matthews hospitals and the slow approval to build a hospital in Southwest Jefferson County. One informant noted:

The financial clout is in the East End of the community. The people in the Southwest are the people working for a living. It actually happens that way and did.

A second informant felt that it was "politics at work:" "83

Two of the consumers on the (FHRC) board were nominated by the then county judge because the South End felt itself under-served, and why aren't the politicians doing something about it? This (the southwest hospital) ... as opposed to the Baptist Humana initiative, which was an imposition from top down, at least in my observation was an initiative that came from the bottom up ... it was a genuine political initiative of people who saw what side their bread should be buttered on, and proceeded to butter.

Perspectives on the Decline of the FRHC

Another topic, the decline and demise of the FRHC, one informant said the more powerful healthcare providers lopbied for the stricter changes in federal rules to sabotage or water down the ability of the FRHC. It included widening the scope of where meetings were to be. The informant suggested that the elite utilized its financial resources and power with the higher level of government to force that agenda.

\section{Section Summary}

This section discussed anecdotal material from informants with high centrality in Louisville in 2005, but who also had obvious direct experience with the LFHC and the FRHC when those local organizations were in existence. The value of this section was insight into the agenda, politics and outcomes of the LFHC and FRHC.

\footnotetext{
${ }^{183}$ This quote was altered to protect the identity of the informant.
} 
The informants consistently reported that market economics drove the politics of healthcare in the city of Louisville during the existence of the organizations. The LFHC and FRHC were in awkward positions of being required to solicit voluntary funds from the same hospital organizations they were supposed to regulate. Power and influence tended to drive the agenda; the well-intentioned members wanted containment submitted to the different actors Extendicare (later Humana) and Hollenbach. These parties had greater resources than the FRHC and were able to push the agenda of growth forward. It is noted that Extendicare/Humana was thought to exhibit growth machine behavior by adept negotiation with the next level of government to achieve growth goals.

\section{Conclusion and Analysis}

This chapter further demonstrates the growth machine thesis in Louisville's past politics and illuminates the distinction between growth machine development activity and federally mandated containment activity in local healthcare planning from 1966 to 1983 . While it is a complex story, the interplay between local and federal agendas was manifested over the historical trajectory. It can be identified that when local healthcare planning was under the control of local actors, it was the elites of growth machine apparatus facilitating development, but when the Federal Government imposed its maximum level intergovernmental support and control it was about non-elites, executing the federal policy of containment.

This section will be structured as follows. It will review the membership and agenda issues. It will then review the other elements of the growth machine thesis that was manifested in the trajectory. 


\section{Review of Control Issues}

The Louisville Area Health Facilities Council (LHFC) was started locally by the growth machine elites in much the same manner as the planning for the Louisville Medical Center decades earlier. It was started behind closed doors at the successor of the Louisville Area Development Association--the Louisville Area Chamber of Commerce and not Louisville City Hall.

The LHFC was dominated by elites, and stayed that way until the larger structure of the Federal Government imposed mandates that the organization be more inclusive of the general public. The mandates were tied to funding rules. The LFHC reorganized into the Falls Region Health Council (FRHC) to represent the larger region, but the growth machine maintained hegemony until a local elected politician who controlled local matching funding sources pressured the FRHC to reorganize and accept more nongrowth machine types.

Further changes in federal policy meant that the growth machine-dominated FRHC was pushed out of existence and no growth-machine members were present on the Kentucky Health Systems Agency West (KHSAW) board. KHSAW remained a pluralistic, non-elite organization as required by federal policy from its beginning in 1976 until it closed in 1983.

\section{Review of Agenda Issues}

The different agendas between the LFHC, FRHC and KHSAW reflected the level

of federal restriction. Initially, the LFHC had little to no federal restriction and was able to push the growth agenda after the growth machine apparatus was able to shore up the ranks to advance a growth agenda. 
Even with the federal policies becoming tighter and tighter, the growth machine apparatus was still in control of the FRHC, it managed to advance its developmental interests despite having to attend to some non-growth health planning. Growth coalition members/the growth machine apparatus appeared able to negotiate between themselves and the State of Kentucky on how to protect their interests in the medical center. The FRHC's development agenda was constrained and repeatedly interrupted by the increasing restrictions tied to the lengthy federal matching grant process.

When the FRHC went out of existence, the elite ability to use healthcare facility construction as a development avenue was extinguished as the KHSAW organization did the federal government's bidding to contain costs. KHSAW was not dependent on any matching grants and was able to micromanage hospitals in a bureaucratic manner and restrict growth of services within those facilities as it received all of its funding from the State of Kentucky and the Federal Government and not local government.

\section{Other Growth Machine Thesis Elements in the Trajectory}

In addition to the complex historical trajectory, it is possible to identify other elements of the growth machine thesis that lend support to it being an explanation of past healthcare politics in Louisville during this time period. These are the role of the local newspapers and the University of Louisville.

The local newspapers were strongly visible growth machine members consistently touting growth. The local newspapers served as cheerleaders and statesmen in encouraging growth--even if it was in conflict with what other growth coalition members' interests. 
The University of Louisville was also a present element, though in a much quieter, path-dependent way. The U of L Medical School dean wanted more than 1000 new hospital beds in the Louisville Medical Center. The University of Louisville was also a reason for much of the early growth in the trajectory that included the Norton Hospital and the new University of Louisville Hospital in the Medical Center. 


\section{CHAPTER VI}

\section{A SOCIAL NETWORK ANALYSIS OF THE HEALTHCARE POLITICAL NETWORK STRUCTURE IN LOUISVILLE, KY BETWEEN 2005 AND 2006}

\section{Introduction}

This chapter will discuss the social network analysis (SNA) results from a snowball sample ${ }^{184}$ of individuals in the Louisville Metropolitan Statistical Area (MSA). The purpose is to test for the presence of the growth coalition in healthcare politics. The overall goal is to identify the patterns of power in healthcare politics at the community level and determine whether the results fit the growth machine model. The individuals in the dataset were collected from lists of hospital board members and officers, and the board members and officers from numerous other organizations in the Louisville MSA. The assumption is that this snowball sample is representative of the healthcare decisionmakers for the Louisville Kentucky area.

SNA is an appropriate tool for identifying and understanding organizational patterns pertinent to the growth machine thesis in the manner suggested by Whitt (1989). Wasserman and Faust (1993) note that one of SNA's primary uses "is the identification of the "most important actors" in a social network" (p.169).

As part of testing the hypothesis of this dissertation, SNA was chosen as a tool to investigate several matters within local healthcare politics.

\footnotetext{
${ }^{184}$ Snowball sampling is known as a non-probability method whereby each person interviewed may be asked to suggest additional people for interviewing (Babbie 2001, p.G7). In this study where a person of
} 
- Is there a coherent network in Louisville healthcare?

- If there is a coherent network then what individuals are central in the network and thus more powerful?

- What organizations are central in the network?

- Is there any coherent elite clique or inner circle that has high centrality?

- Where do the growth coalition livelihoods as whole sectors fit in relation to the network?

Together, answers to these questions should answer the research question as to whether the growth machine thesis was manifested in the network of healthcare politicians or actors.

In keeping with the case study design, the next chapter will report the field interview results that will build upon this chapter's results. The field interviews should provide a sense of the dynamics within the network.

This chapter argues that social network analysis results regarding centrality, clique analysis, multi-dimensional scaling, and network mapping on a snowball sample support the empirical portion of the growth machine thesis as an explanation of the power structure of local healthcare politics in the Louisville, Kentucky Metropolitan Statistical Area (MSA). There is strong support for this in terms of centrality of both individuals and organizations. Furthermore, when the network is re-framed in terms of livelihood sectors, there is support that livelihoods listed as part of the growth coalition have strong centrality and ties among each other. The results of using network tools have the 
potential to support the hypothesis of this dissertation that the growth machine thesis explains the power structure of local healthcare politics.

This chapter will be ordered as follows. There will first be a discussion and critique of SNA. Pertinent processes of data gathering and cleaning are discussed. Early analysis issues will be reviewed. Results of centrality and clique analysis are then reported. The SNA results in terms of growth coalition livelihood sectors will then be reported. This chapter will close with summations and conclusions.

\section{A brief discussion and critique of SNA}

Description

SNA is a formalized, quantitative approach to studying networks (Adam and Kriesi 2007, p.130). According to Scott (1991) social network analysis "is useful for investigations of kinship patterns, community structure, interlocking directorships and so forth" (p.2). According to Knoke and Kuklinski (1982) "A network is generally defined as a specific type of relation linking a defined set of persons, objects or events" (p.12).

They state the premise of this research as:

The structure of relations among actors and the location of individual actors in the network have important behavioral, perceptual, and attitudinal consequences both for the individual units and for the system as a whole (p.13).

The various texts agree that SNA is based on "graph theory" in which there is not just a pictorial aspect, but also a mathematical aspect to the relationships of a social network, especially when it comes to measures of centrality.

The UCINET 6 (version 6.145) software package was used for conducting all SNA analyses in this study. UCINET 6 is a very powerful and versatile software with multiple routines to generate tabular, numerical and graphical analyses. 


\section{A Critique of SNA}

SNA is one of three approaches to describe policy networks. According to Adam and Kriesi (2007) the foundation of the policy network is the observation that policy is made in "policy domain-specific subsystems" that involve both public and private actors (p.129). One concept of policy network in addition to SNA is the study of governance structure through negotiations and problem-solving among state and private sector actors with focus on organizations in particular. ${ }^{185}$ The other concept refers to the study and categorization of all the different patterns of interaction among private and public actors that are empirically possible. Adam and Kriesi (along with Dowding, 1995, p.158) note that on the other hand, SNA focuses on the relations between actors and not on the characteristics of the actors themselves. ${ }^{186}$

Adam and Kriesi note two weaknesses of SNA. One weakness of SNA (along with all network approaches) is the dependence upon other concepts for interpretation. Second, these methods also do not give any insight into the origin or dynamic change of networks (p.130). ${ }^{187}$

In what appears to be some consonance with Adam and Kriesi, John (1998) notes that with regard to the study of politics, SNA requires the specification of the kind of contacts being investigated. John (1998) stated:

Some political relationships are symbolic or ceremonial; some are operational and are to do with implementing policy; and others are about policy choices driven by public opinion and political pressure. Is the network analyst to incorporate all these interactions or some of them? (p.309)

\footnotetext{
${ }^{185}$ See John and Cole, 1995.

${ }^{186}$ Adam and Kriesi cite Dowding.

${ }^{187}$ Dowding also echoed that network analysis "has proved inadequate in providing fully determined causal analysis of particular networks in structural terms" (p, 158)
} 
John recognized that SNA has been used little in the study of political networks. It has been used primarily in social and economic research (p.306), so it is rather nascent for political purposes.

In response to the critiques, it is accepted that indeed this dissertation's use of SNA is a unique if not new way to study a political network. It is dependent upon Logan and Molotch's framework to conceptualize the SNA results and to delimit the categorical labels of cases in the name of classification. The SNA results will be of a limited nature, but should be sufficient for testing the hypothesis.

While SNA should provide the information to power structure questions regarding local healthcare politics in Louisville, it only can demonstrate the overall static information at a point in time of who is in the network and its positions, especially those of prestige and power. It can identify the connections between organizations and individuals in terms of "interlocks." SNA cannot answer the political-economic questions of who actually makes the decisions and for what agenda?

Thus the tenets of the empirical portion of the growth machine thesis cumulatively form a measuring stick for the network. ${ }^{188}$ If the SNA results support the hypothesis of the growth machine thesis explaining local healthcare politics, then the actors from the livelihood sectors Molotch identified as being of the growth coalition/growth machine apparatus will have higher centrality scores than the other livelihood sectors. There also will be at least one clique consisting of actors from growth coalition livelihoods with high average centrality. As will be discussed below, centrality in a social network is accepted as an indication of power and prestige.

\footnotetext{
${ }^{188}$ For the purpose of clarity, the SNA is not being used to prove the normative and prescription portion of the growth machine thesis encouraging anti-growth political action.
} 


\section{Utilization of SNA Tools}

In reality, very few of the available SNA tools were needed to conduct the necessary analyses to test the hypothesis successfully. The tools that produced significant results were: 1.) Bonacich centrality, 2.) clique analysis, 3.) network mapping, and 4.) multidimensional scaling (MDS). When sufficient evidence was found, exploration stopped. ${ }^{189}$

\section{Data collection and cleaning issues}

The data collection and cleaning processes were based on the requirements of the UCINET software package. The data had to be accumulated and organized in a format that could be read and processed by the software.

The data was collected from publicly available sources available in 2005 and 2006. The initial organizations and persons of interest were the board members and officers of the healthcare organizations in the Louisville MSA. Names of board members of various other "for-profit" and non-profit organizations were included. The organization rankings published in Business first for 2005 were used as a cumulative starting point for inclusion of the community at large. ${ }^{190}$ Internet-based databases from www.guidestar.org and the Kentucky Secretary of State website were used to enlarge the snowball sample and provide further information on pertinent (non-profit and for-profit) organizations and individuals. The Gale Group and Dun and Bradstreet/Hoovers databases available through the University of Louisville Ekstrom Library were also consulted for names of officers and board members. The websites of various, local government units, including Louisville-Metro Government, also were consulted for the

\footnotetext{
${ }^{189}$ There is a point when too much analysis can detract from reaching a conclusion.
} 
names of elected officials and paid employees. Together all these sources provide a substantial dataset of the actors in the Louisville MSA.

The data was shaped into an incidence matrix. A Microsoft Excel spreadsheet was the compilation tool for the matrix. The data fields included individual name, unique individual identification number, unique organizational identification number, organization name, organization type, credential, position, address, zip code. Not all these data fields were necessary, but preparation was made in case further analysis was indicated.

An individual could have more than one case or row of data. Typical repetition of an individual's name occurred when they had more than one role in an organization and/or held positions in more than one organization (thus comprising interlocks). There were 8420 total cases in the initial dataset and it is an assumption here that this dataset is representative of the Louisville MSA.

Even though care was taken to be accurate, early analyses pointed to data errors. A common problem was erroneously assigned identification numbers. When the problems were corrected, the analyses were re-run for corrected results.

\section{Early Analysis Issues}

Analysis with the UCINET software was conducted with certain intentions. The following analyses using UCINET routines were completed on the outset for both organizations and individuals:

1. Clique analysis (several values of $N)^{191}$

2. Component analysis

${ }^{190}$ This publication had a weekly list of the leading organizations in various sectors with some names of officers. 
3. Freeman centrality analysis

4. Bonacich centrality analysis

5. Multi-dimensional scaling (MDS) (Non-Metric)

6. Creation of network diagrams with the "Netdraw" and "Pajek" components of UCINET

The purpose of using all these analyses was to be thorough. Not all of the analyses were used due to the clique and centrality results. In the process of analysis, there were some initial problems with skewness and dataset size. The skewness was related to the presence of "registered agents" in the database. The dataset's size was also a hindrance to conducting graphical analyses. This section will also discuss the efforts to correct these data and analysis problems.

\section{Skewness}

The first analyses indicated that the dataset was negatively skewed—or it was skewed to non-elite branch offices of organizations based outside of Kentucky and not involved in healthcare. Further investigation showed that the "branch" entities were essentially client lists of "registered agent" firms with the registered agents being the common denominator of organizations of the cliques and the registered agents were the most central. To correct this skewness, all cases of "registered agents" were removed from the dataset reducing it in size to 7515 cases ${ }^{192}$

Initial Implications of the Database Size

The large size of the dataset meant several problems. There were several limitations in the analyses that could not all be corrected and limited the possible forms

\footnotetext{
${ }^{191}$ UCINET 6 can be instructed to look for cliques of different sizes.

192 This in actuality changed the skewness to the other direction.
} 
meaningful results. There were too many nodes or points that made for cluttered, meaningless diagrams.

The reduction of the dataset to a size of 8240 to 7515 cases did not improve the ability to depict the network graphically through the UCINET Netdraw, Pajek or MDS routines. Graphical depictions continued to be meaningless due to the large amount of data. ${ }^{193}$ After the first round of centrality routines, the cases with a Bonacich eigenvalue of 0 were eliminated from the dataset since they had no significance in the network, which reduced the dataset size to 4438 bases. Even that was too large for any meaningful graphical depiction with regard to individuals and organizations at the city level. Meaningful graphical analysis was not achieved until the livelihood sectors were studied, as there were fewer nominal variables in the incidence matrix. The centrality and clique analysis produced the only meaningful results about individuals and organizations.

\section{Centrality Analysis Results}

This section will discuss the centrality analysis results of the SNA on the 4438 case dataset. As mentioned earlier, the first centrality results were skewed to the nonelite on the basis of the role of "registered agent" and correction was made to adjust for this. Despite changes in values the centrality rankings of individuals and organizations ${ }^{194}$ were the same whether the dataset was $n=7515$ or $n=4438$ overall. This suggests that the dataset probably could have been reduced even further with similar ranking results.

Centrality as a SNA measure is based on the idea that power is relational and that the most central individual or individuals hold the power. Hanneman and Riddle (2005)

\footnotetext{
193 The graphical depictions were so crowded that it was impossible to make any meaningful interpretation of the networks even down to 4438 cases.

194 This is not to say that the actual centrality scores stayed the same because the actual numerical values are dependent upon the number of connections possible in a network
} 
note, "An individual does not have power in the abstract, they have power because they can dominate others-ego's power is alter's dependence" (chapter 13). ${ }^{195}$ Centrality can be of a local type among the adjacent or close relationships, or among the universe of individuals in the network.

Given that this is a study of local healthcare politics in the Louisville MSA, the type of centrality that provides community-wide results is of a global nature. There are two primary measures of centrality in SNA: "Freeman degree" and "Bonacich power." The UCINET software has routines to conduct for both centrality types.

The Freeman degree measure is a matter of counting how many links or degrees an actor has. In this measure the actor has both out-degrees and in-degrees. The significance of in-versus-out refers to whether the actor is on the receiving end of communication or the sending of communication respectively. The higher number of out-degrees an actor has might be taken as an indication of that actor's influence. Basic descriptive statistics ${ }^{196}$ can be run of a network's cumulative score to indicate homogeneity or heterogeneity of power (Hanneman and Riddle, Chapter 10).

The Bonacich power measure of centrality is a modification of degree centrality. The Bonacich measure not only takes into account the number of connections an actor has, but also the number of connections those other connections have. So, in this measure, an individual actor's high number of connections can be of little consequence unless those connections also have a high number of connections. Bonacich's measure is considered to be superior to the Freeman degree in identifying centrality.

\footnotetext{
${ }^{195}$ This is an online text and is being cited in accordance with APA style.

196 These include mean, standard deviation, sum, variance, minimum, maximum.
} 
In a manner much like Factor Analysis, Bonacich's centrality is expressed in terms of "eigenvalues." Hanneman and Riddle said

The eigenvector approach is an effort to find the most central actors (i.e., those with the smallest farness from others) in terms of the 'global' or 'overall' structure of the network and to pay less attention to patterns that are more 'local.'

Furthermore Hanneman and Riddle note that factor analysis identifies the "dimensions" of the distances among actors." The eigenvalue is the mathematical expression of the location of each actor with the respect to the dimension (Chapter 13).

Bonacich's equation gives "each actor an estimated centrality equal to their own degree plus a weighted function of the degrees of the actors to whom they ${ }^{197}$ were connected" (Hanneman and Riddle, chapter 13). This is mathematically stated as

$$
\mathrm{cj}=\Sigma_{\mathrm{j}} \mathrm{r}_{\mathrm{ij}}\left(\alpha+\beta \mathrm{c}_{\mathrm{j}}\right) .
$$

According to Scott

$\ldots$ the centrality weighting is itself modified by the two parameters $\alpha$ and $\beta$. $\alpha$ is introduced simply as an arbitrary standardizing constant which ensures that the final centrality measures will vary around $1 . \beta$ on the other hand, is of more substantive significance. It is a positive or negative value, which allows the researcher to set the path distances, which are to be used in the calculation of centrality (p.89).

Scott's criticism of the Bonacich measure is that the $\beta$ values in the formula are arbitrarily assigned by the researcher (p89)

In light of Scott's criticism of the potential arbitrary skewing of values, the default value of $\beta$ as assigned in the UCINET 6 Bonacich eigenvalue routine of 0.0 was used in this analysis. According the UCINET users guide, "A value of 0 gives a centrality measure directly proportional to the degree of each vertex" (UCINET). Since the case

${ }^{197}$ According to Scott the $\beta$ is a weighted value added to $\mathrm{c}$ and not a multiplier (p.188). 
study design is one of exploration and not experimentation, there was no compelling reason for adjusting the $\beta$ in this routine.

The rest of this section will discuss the centrality results. Organization names will be disclosed. The individuals will only be discussed in terms of unique identification numbers and sectors to protect informants' identities for the third part of this case study.

Centrality of Organizations in Louisville

Table 7 displays the rankings of organizations with the highest Bonacich eigenvalues. There are several significant points. First, the development sector has an overwhelming presence especially with "Greater Louisville Inc," having a centrality value that is 603 percent higher than the next most central organization. It may be more central because the "Health Enterprises Network" was included in the Greater Louisville Inc. cases. ${ }^{198}$ Second, as evidenced in the table, there is a steep gradient of scores. Third, Louisville-Metro Government was ninth in centrality on the list, which indicates that government is a less-central player in the network. Fourth, the anomalies of this list are the Metro United Way and the now-defunct "getCare" Health Network. ${ }^{199}$ The getCare Network was an organization spear-headed by the Louisville-Metro Health Department and primarily funded by a Robert-Wood-Johnson Foundation "Communities in Charge" grant to provide free or reduced medical services to uninsured individuals. Otherwise, other than the healthcare systems themselves, typical growth coalition entities have high centrality.

\footnotetext{
${ }^{198}$ Health Enterprises Network is a "network" of Greater Louisville Inc., but it is not a separately incorporated organization. As will be discussed later, many of the actors interviewed felt that it was its own organization apart from Greater Louisville Inc., despite not being incorporated.

${ }^{199}$ They are redistributive or charitable organizations and of a different nature than the rest.
} 
Table 7

Top 20 Bonacich Eigenvalues Values for Louisville organizations in 2005

Organization

Eigenvalue Score

Greater Louisville Inc

Fund for the Arts

22.059

Jewish Hospital Healthcare Services.....

Frost Brown Todd Law Firm.

Norton Healthcare.

Louisville Development Foundation. 10.875

University of Louisville Hospital/University Medical Center. 8.269

Louisville Medical Center Development Corporation 8.238

Louisville/Jefferson County Metro Government. 8.098

Anthem Health Plans of Kentucky ......................................... 7.928

Republic Bank and Trust........................................................

Fund for the Arts Properties Foundation.......................................

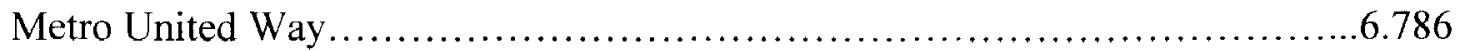

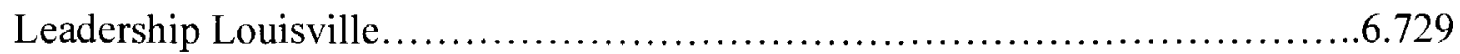

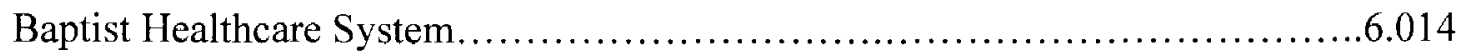

Wyatt Tarrant and Combs Law Firm..........................................5.64

Alliance for Life Science Technology Commercialization, Inc................5.567

$\mathrm{U}$ of $\mathrm{L}$ and Jewish Hosp. Cardiovascular Institute..............................

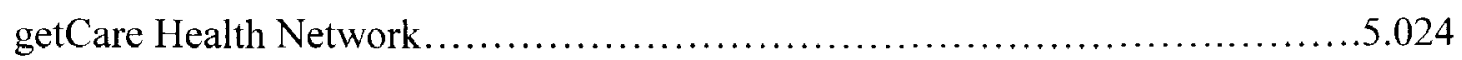

Kindred Healthcare...................................................... 4.797 
Table 8

Top 20 organization Bonacich Eigenvalues after GLI is removed from the dataset

Organization

Eigenvalue Score

Frost Brown Todd

Jewish Hospital Health Services.............................................51.801

Republic Bank and Trust.......................................................11.995

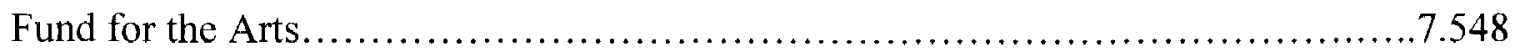

Leadership Louisville..........................................................6.948

Louisville Development Foundation.............................................5.477

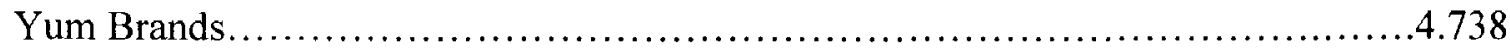

Metro United Way ...............................................................4.442

Fund for the Arts Properties Foundation.............................................107

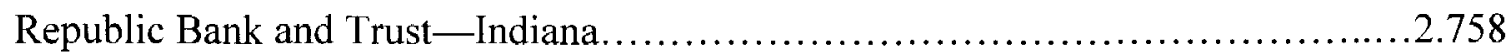

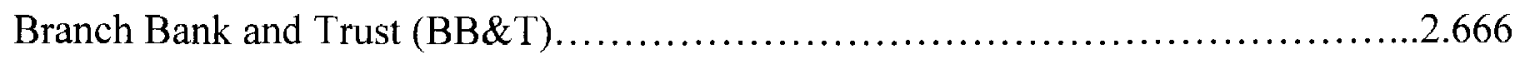

Goldberg and Simpson Law Firm................................................2.596

Indiana University Southeast.....................................................425

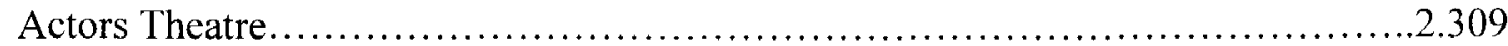

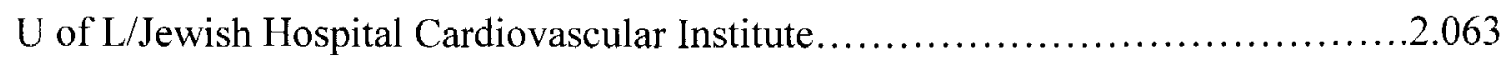

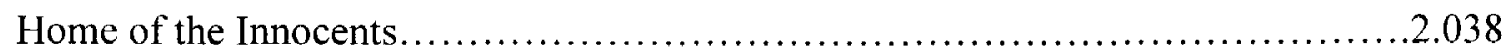

Baptist Healthcare System...................................................

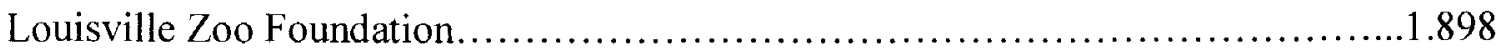

Lynch Cox Gilman Maher Law Firm.........................................1.702

getCare Health Network (now defunct) ..........................................602 
Given that Greater Louisville Inc (GLI) is an overwhelming outlier ${ }^{200}$ and appears to skew the data, a number of questions arose. How powerful is GLI by its absence?

Because GLI held so much centrality there was the question of whether a truer picture of power and prestige could be presented if GLI was removed from the dataset? In a sense, a control ${ }^{201}$ was placed on the dataset to test the network centrality further. The entries from GLI were removed from the Excel file, the data was reprocessed and Table 8 displays the results.

Again, several significant observations can be made from the tabular results. Eight of the organizations in the first list dropped out including Louisville Metro Government and Norton Healthcare. Second, the Frost Todd Brown law firm and Jewish Hospital Health Services absorbed much of the value and in turn became the outliers ${ }^{202}$, which indicate their inherent centrality or perhaps significant interlock between Jewish, Frost Brown Todd and GLI. Again, the now-defunct getCare Network stayed in the top 20 , which suggests that it was bolstered by individuals with high degrees of centrality. Overall, these changes suggest that GLI (in addition to its own centrality) is a "knot" or "cut-point" (Scott, pp.110-111) in the network by which numerous entities are connected into the network. Furthermore, this test supports the concept that economic development or growth actors are at the heart of the healthcare politics power structure network.

\section{Centrality of Individuals}

The same Bonacich centrality analysis was conducted on individuals in the same manner as on organizations. Table 9 lists the top 20 individuals in the network. The

\footnotetext{
${ }^{200}$ Mean $=1.799$ Std Deviation $=8.654$

${ }^{201}$ Some research designs allow for a control group to compare whether a stimulus or variable applied to a experimental group actually had some effect (Babbie, p. G3).

202 Mean $=0.488$, Standard Deviation $=5.827$
} 
Table 9

$\underline{\text { Top } 20 \text { Individual Bonacich Eigenvalues in } 2005 \text { with Their Identified Livelihoods }{ }^{203}}$

Individual actor Eigenvalue score

M1476 (Attorney) 27.005

M0031 (Healthcare) 23.252

M2985 (Utilities). .22 .823

M3715 (Healthcare). 22.777

M2868 (Education) 22.315

M0044 (Politician) 21.642

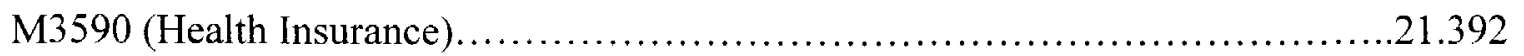

M1656 (Development)................................................20.680

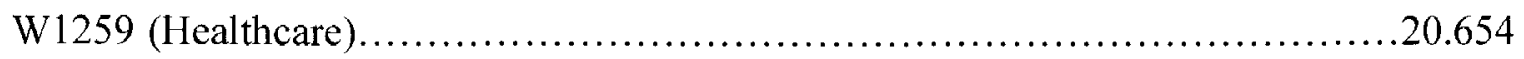

M3389 (Development)..................................................20.506

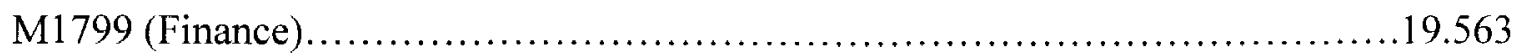

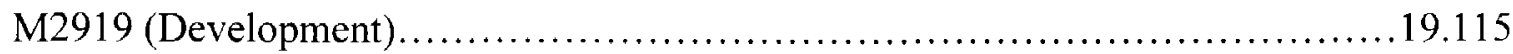

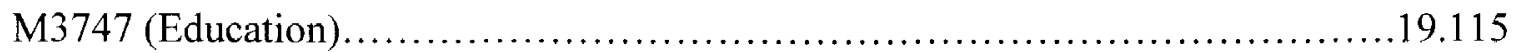

W1084 (Development)............................................ 19.115

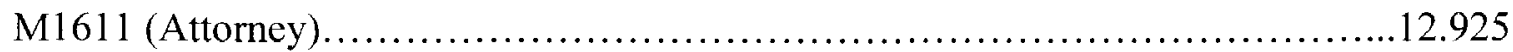

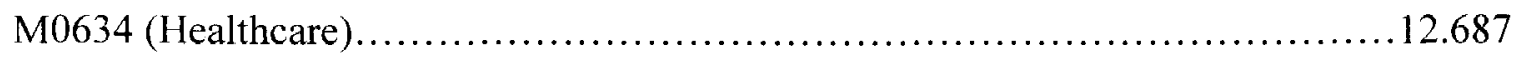

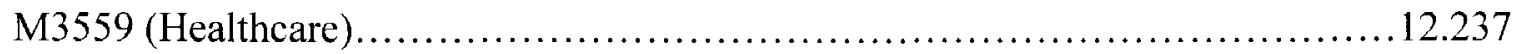

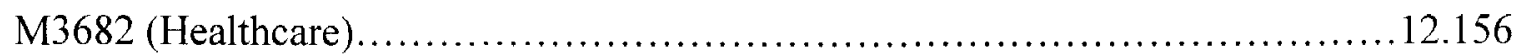

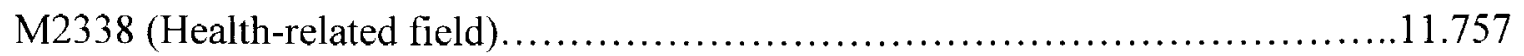

203 The actual names of these individuals are not disclosed due to human subject protection standards. 
growth coalition livelihood sectors present include utilities, attorneys and finance and education. It is interesting that the highest-ranking politician is ranked sixth in the list. Like the organization scores, the individual Bonacich scores demonstrated positive skewing of the data, but with a less steep gradient. ${ }^{204}$

In further analysis there is a strong correlation between membership or leadership in GLI and membership on a hospital system board. As with the organizations, when the GLI cases are removed from the dataset, a similar centrality result is found. Table 10 displays the results. Similar to the organization results, M1476 gained in value. Essentially, 18 of the 20 in this second list are attorneys from the same law firm. The ones with higher scores have civic involvement on a number of boards. There are actually more attorneys from the same law firm that could fit in this table because they also have an eigenvalue of 10.984 with no apparent membership in other organizations as officers or board members in the snowball sample. This list reflects the centrality of the Frost Brown Todd Law Firm secondary to GLI. While this list reflects the key position that GLI has in the network, it is likely that some Frost Brown Todd members have their centrality because they are connected to certain firm members who are much more central. The individual results reflect the organizational results given the high centrality of attorneys from Frost Brown Todd. However, the results again seem to buttress the suggestion that GLI is a knot or cut-point by which many of the actors are connected in the network. 
Individual Bonacich Eigenvalues after GLI Cases were Removed from the Dataset Individual actor Eigenvalue score

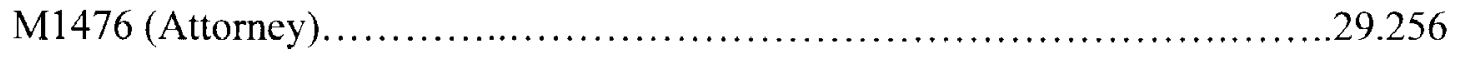

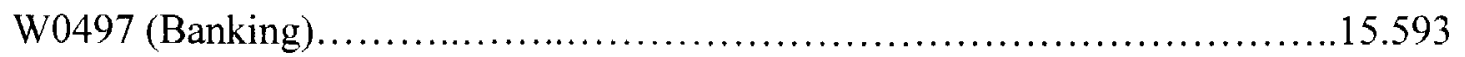

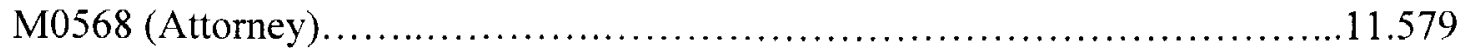

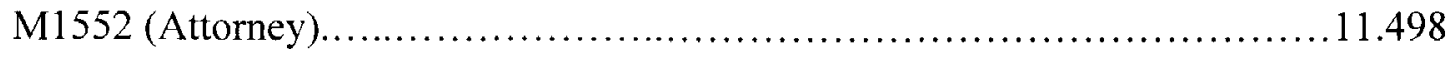

W0207 (Attorney) ............................................................11.160

M0242 (Attorney) ........................................................11.153

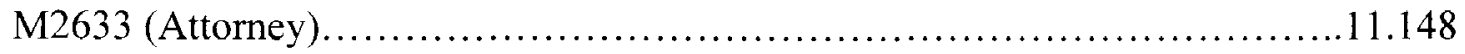

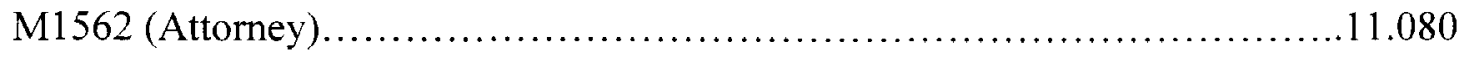

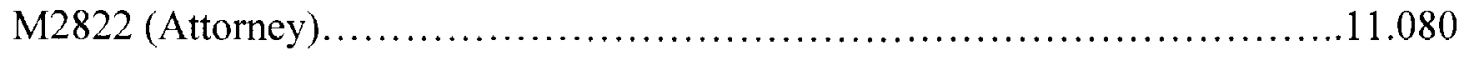

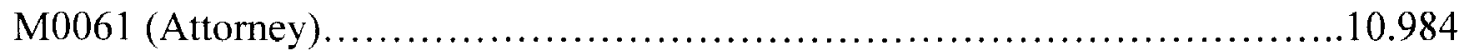

M0098 (Attorney) ...................................................... 10.984

M0119 (Attorney) ....................................................... 10.984

M0127 (Attorney) ......................................................... 10.984

M0157 (Attorney) ....................................................... 10.984

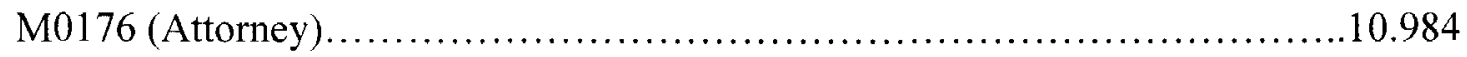

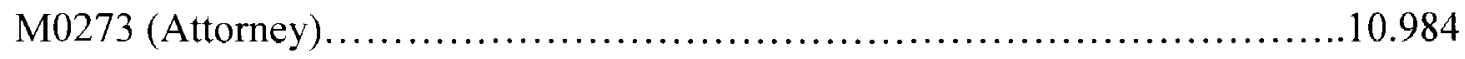

M0275 (Attorney) ................................................... 10.984

M0282 (Attorney)..................................................... 10.984

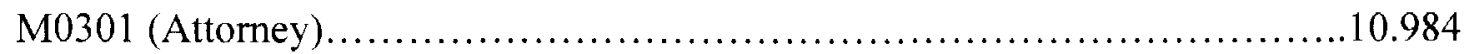

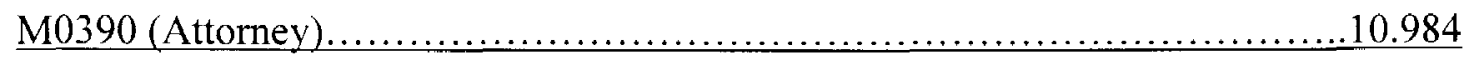

${ }^{204}$ Mean $=1.799$, Standard Deviation $=8.654$ 


\section{Clique Analysis}

This section will discuss the results of the analysis of cliques of individuals within the network. The UCINET software has the capability to identify a set called a "clique" which is "a sub-set of points in which every possible pair of points is directly connected by a line and the clique is not contacted in any other clique" (Scott, p.117). The UCINET software can identify cliques of any particular size.

Given that the basis of growth machine thesis has elitism at its core, clique analysis is useful for exploring whether there is a central-most or primary elite clique. Such a clique would have a concentration of the ranking individuals or it would have an overall high concentration of individuals with relatively high eigenvalue scores versus multiple cliques with one central individual inflating the clique's average eigenvalue.

There is one disclaimer in this analysis of cliques: it must be assumed that all relationships within the cliques are reciprocal, and this is therefore an undirected graph (with equal exchanges of information). Given the gargantuan size of the network and the manner in which information was gathered for the analysis it cannot be determined whether these cliques were strong cliques or weak cliques (Scott, p.118). If this were a more narrowly defined sample with fewer actors, analysis would then be feasible for identifying weak and strong cliques. ${ }^{205}$

Nevertheless for the sake of argument, what would detract from the growth machine thesis model in the use of clique analysis will be the lack of any clique with either a high cumulative total of Bonacich eigenvalue scores, or a lack of any clique with

\footnotetext{
${ }^{205}$ This comment is provided for people interested in SNA. This is actually Scott's terminology (p. 190). $\mathrm{He}$ is applying the terms strong and weak usually used to describe components to cliques. A strong component is where the lines (of communication) that make up the paths between the points are aligned
} 
a high average. In such a situation, it would be conceived that all of the individuals with high eigenvalue scores would be spread out and not register in any clique with any other individual with a large score. Fortunately, this was not the case.

In the concept of identifying the most central clique the most helpful analysis was when minimum clique size was $n=3$. At this setting the UCINET routine identifies all cliques that are the size of three (3) cases (whether individuals or organizations) and higher. At $\mathrm{n}=3$ UCINET identified 311 cliques of individuals of various sizes within the dataset of 4438 cases. The UCINET output text file was read into an Excel spreadsheet for further processing. Eigenvalues were inputted for each clique member. Total and average Bonacich eigenvalues for each clique were computed.

An average eigenvalue score of 12 was chosen as a floor for further clique analysis given the centrality gradient in the analysis of individuals. There were 28 cliques that had an average score of 12 or higher and two cliques that stood out.

Clique number 53 was the predominant clique with the highest average centrality. It had seven members with a cumulative eigenvalue of 113.091 and an average eigenvalue of 16.156 . Table 11 lists the members. This clique consisted primarily of healthcare figures (executives and physicians). The other clique members were representative of the growth coalition sectors, who also had been hospital organization board members.

The next most central clique was number 106 . It was the same size as clique number 53 but had lower cumulative (187.981) and average (15.665) eigenvalue scores. Eight members in clique 53 were unique to it from \#106 and are listed in table 12.

and do not change direction (p.106). Weak components merely are identified as connections (p. 107). This kind of information would be gathered in a survey-based research design. 
It is significant that there was little redundancy between the two cliques. It is also significant that clique \#106 consisted primarily of healthcare executives and had growth coalition members with a history of hospital board membership.

Table 11

Clique \#53 with Highest Average Bonacich Eigenvalue Score with Actor with Corresponding livelihood ${ }^{206}$

1. M0031 (Healthcare)

2. M0634 (Healthcare)

3. M1476 (Attorney)

4. M1542 (Physician)

5. M2004 (Physician)

6. M2357 (Development)

7. M2868 (Education)

8. M3065 (Local Business Executive)

9. M3559 (Healthcare)

10. M3634 (Healthcare)

11. M3682 (Healthcare)

12. M3715 (Healthcare)

Going back to the original concept of a clique being a group of individuals where the clique is not a sub-group of any other group, we can conclude that there is support for an elite-group of individuals that relate to each other exclusively within this network. In looking at the clique membership, there was evidence of healthcare actors relating to each other. In both central cliques, the non-healthcare individuals were from growth coalition 
livelihood sectors, which lend support to the growth machine thesis idea that local elites are in power.

Table 12

Clique\#106 with Second Highest Average Eigenvalue Score with Actor and Livelihood

1. M0031 (Healthcare)

2. M0044 (Politician)

3. M0093 (Local Professional)

4. M0465 (Local Business Executive)

5. M0669 (Healthcare)

6. M0997 (Healthcare)

7. M2868 (Education)

8. M3081 (Healthcare)

9. M3389 (Development)

10. M3559 (Healthcare)

11. M3715 (Healthcare)

12. W1259 (Healthcare)

\section{Analyses of the Network in Terms of Growth Coalition Livelihoods}

There was still the question of how the growth coalition fits in the overall Louisville healthcare politics network. Although it can be generally concluded by further extrapolation that the interlocks do matter through the Bonacich eigenvalues, the effect of inter-locks on the overall community as a whole has not been assessed per se.

\footnotetext{
${ }^{206}$ Like the centrality results, the names of the clique members are not being disclosed in keeping with human protection standards.
} 
At face value, there were numerous interlocks in 2005 between the organizations listed in Table 8 . The ranking individuals in tables $9,10,11$, and 12 certainly embody interlocks among the ranking organizations. Focusing on the inter-locks of those organizations alone would be interesting, but it loses perspective on the overall community political structure with regard to local healthcare politics.

To assess the healthcare political structure of the whole community a dataset of 7470 cases was used. ${ }^{207}$ Even though it was obvious from previous analyses that 41 percent of the larger set was essentially irrelevant actors, the larger data set should lend more credibility to such an analysis of the overall community picture. The added benefit of using the larger dataset also can inform about what livelihood sectors are outside of or inside the center of the community network.

One benefit of looking at sectors also meant the ability to utilize some of the graphical routines of UCINET including "Netdraw" and MDS. Since there were only 28 sectors or nodes in this case, visually meaningful results were achieved.

Using Microsoft Excel, each case within the dataset of 7470 cases was assigned a sector label. The assigned sector best reflected the livelihood (profession/occupation) or organization of the individual. (For example all cases belonging to an individual who is an attorney were labeled "Law.") At face value the first attempt was to use only those livelihood sector names as listed by Logan and Molotch in their 1987 chapter in Urban Fortunes but there were two many cases that would have meant a large "other"

\footnotetext{
${ }^{207}$ Cases that were not actual human beings were removed from this dataset. Some corporations were directors or managers of other organizations.
} 
category. ${ }^{208}$ The sector names were selected to reflect the reality and to demonstrate which livelihood sectors were not involved as well as which livelihood sectors were involved. The livelihood sector names are as follows.

1. Accountants

2. Advertising

3. Colleges

4. Branch (Corporate Capitalists of Multi-locational firms)

5. Development

6. Doctors

7. Elite (Social Organization)

8. Foundation (Charitable organization)

9. Government

10. HRB (Health-Related Business)

11. Healthcare (other than hospitals)

12. Hospitals

13. Insurance

14. Law

15. Media

16. MH (Mental Health)

17. National (Home Office of a Corporation based in Louisville)

18. Nonprofit

19. Other

${ }^{208}$ With a large general "other" category that included all other different entities, much would likely be missed in analysis. Creating other unique categories seems to be in harmony with the growth machine 
20. Politicians

21. PI (Property Investing)

22. Public (Health organizations)

23. Finance (Real Estate Financing)

24. Retailers

25. Sports

26. Technology

27. Arts (Museums, Theaters, Expositions)

28. Utilities

The resulting affiliation matrix consisted of the growth coalition livelihood sectors. ${ }^{209}$

The remainder of this section will be presented as follows. First, the Bonacich eigenvalues of the sectors will be reviewed. Then the network map as created by the UCINET "Netdraw" routine will be discussed. The MDS results will be presented. Possible generalizations will be examined and then a summary will follow.

\section{Bonacich Eigenvalue Results}

The Bonacich eigenvalues in the livelihood sector analysis may shine some light as to why the Frost Brown Todd law firm was able to subsume GLI's centrality, and how case M1476 (an attorney) was able to subsume even more centrality when GLI cases were removed. The "law" sector had a total score of 141.380 out of a sum of 149.229 , which means that it possessed 94.7 percent of the value or probability. ${ }^{210}$ The

thesis as the specific categories appear to be locally dependent.

209 There was an initial data problem in that the UCINET DL formatting routine did not read 377 cases. Reducing the sector names to one word reduced the missing cases down to 3 .

210 The reader is referred to the idea that the Bonacich measure is akin to Factor Analysis. Only so much probability is generated and therefore $149.229=100$ percent of the possible value or probability. A more base way of stating this is that the lawyers in Louisville as a group are overwhelmingly the most powerful group of individuals in town. 
"development" sector was next with an eigenvalue of 2.283. The "hospitals" sector was third with an eigenvalue of 2.208 . For the record, the distribution of eigenvalues was positively skewed given that the mean was 5.330 , and the standard deviation was 26.189 . A brief interpretation of the centrality result is that local attorneys are also central in the "development" sector and manifest as being the foremost central livelihood in the network of healthcare politics in Louisville, Kentucky.

\section{Network Mapping}

Network mapping in SNA is based on graph theory. According to Scott, "A graph diagram aims to represent each row or column in an incidence matrix-each of the cases or affiliations under investigation by a point on the paper" (p.67). Furthermore, Scott notes that "it is the pattern of connections that is important and not the actual positioning of the points on the page" (p.67).

The network map generated through the UCINET "Netdraw" routine in figure 2 gives us a picture more of who is not involved versus who is involved in local healthcare politics. There is a fairly close "neighborhood" of growth coalition livelihood sectors from the pertinent livelihood sectors in the network as signified by adjacent points with one another (Scott, p70). What is interesting is that the "other" livelihood sector of various "other" types of livelihoods also was in the mainstream of the network. In retrospect, some of those cases included in this "other" category could have fit in with Logan and Molotch's category of "self-employed professionals and small retailers" (pp.82-84) as those individuals tended to provide a specialized service or good. ${ }^{211}$ The

\footnotetext{
211 These organizations did not seem to soundly fit into the category. Furthermore, they as a livelihood only had a Bonacich eigenvector value of 0.062 so they were not very central in the network and not likely consorting with the more elite or central livelihood sectors. Further analysis would be needed to explore their actual relationships within the network.
} 
neighborhood also included "doctors" on the fringe, which indicates that they are connected players in the network, but to a lesser extent than other sectors. The sectors of mental health agencies, formal government bodies, elite social organizations, sports entities, insurance, and technology firms have few connections with the rest of the network. There were some health-related businesses not involved in the network but what may be the most eye-opening part of this result is that the livelihood sector of public health organizations was connected with the network of livelihood sectors.

Figure 2

HRB

Network Map of Livelihoods in the Louisville, KY Metropolitan Area

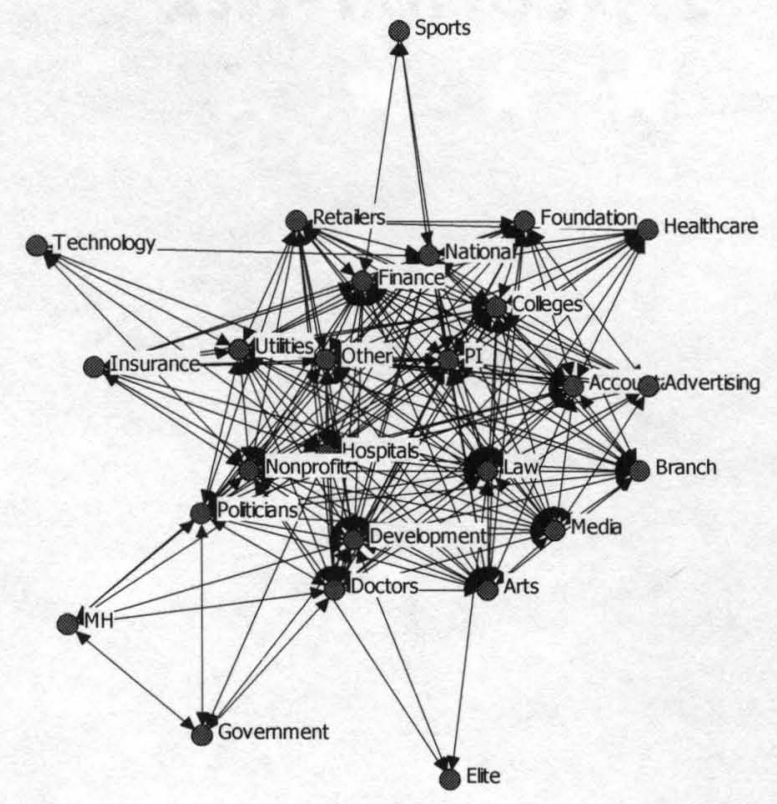

Multi-Dimensional Scaling (MDS)

MDS has broad applications and is considered to be an alternative to factor analysis (Wasserman and Faust, p.288). Its general goal is "to detect meaningful underlying dimensions that allow the researcher to explain observed similarities or dissimilarities (distances) between the investigated objects" 
(http://statsoft.com/textbook/stmulsca.html). Specifically to SNA Borgatti $(1997)^{212}$ writes that the purpose of MDS is "to provide a visual representation of the pattern of proximities among a set of objects." He notes that it is used to "provide a visual representation of a complex set of relationships that can be scanned at a glance" (http://www.analytictech.com/borgatti/mds.htm). Therefore, MDS goes one step farther than factor analysis to give us a valued, graphical depiction of a network.

MDS has both numerical and graphical components that can add additional understanding to a network of actors. Its output "is a set of estimated distances among pairs of entities, which can be expressed as coordinates in one-, two-, or higher dimensional space" (Wasserman and Faust, p.288). Its graphical depiction is also called a "Shepard's diagram" that resembles a Cartesian plane of points used in other mathematical applications. (http:/www.statsoft.com/textbook/stmulsca.html)

Borgatti offers several guidelines for interpreting the MDS map. First he notes that "All that matters in an MDS map is which point is close to which others." Borgatti notes that the axes are "meaningless" and "that the orientation of the picture is arbitrary." Furthermore, Borgatti notes that the two keys to interpretation are noting the "clusters" or groups of points that are closer to each other than to other points and the "dimensions" that are "item attributes that seem to order the items in the map along a continuum"(http://www.analytictech.com/borgatti/mds.htm).

There are two prior, known examples of MDS used to study community elites. Laumann and Pappi (1973) used the "smallest space analysis" (a form of MDS) to

\footnotetext{
${ }^{212}$ Borgatti is also one of the architects of the UCINET software package. There are also two versions of this page on the Internet. The other is at http://www. analytictech.com/networks/mds.htm.
} 
identify the network of a German city's elites. Galaskiewicz (1979) used "smallest space analysis to analyze the organizational networks in a Midwestern city.

Figure 3 is the initial result from the UCINET MDS routine. Similar to the network map, the public health and health-related livelihood sectors are extreme outliers

Figure 3

Initial MDS result of Livelihoods in the Louisville, KY Metropolitan Area

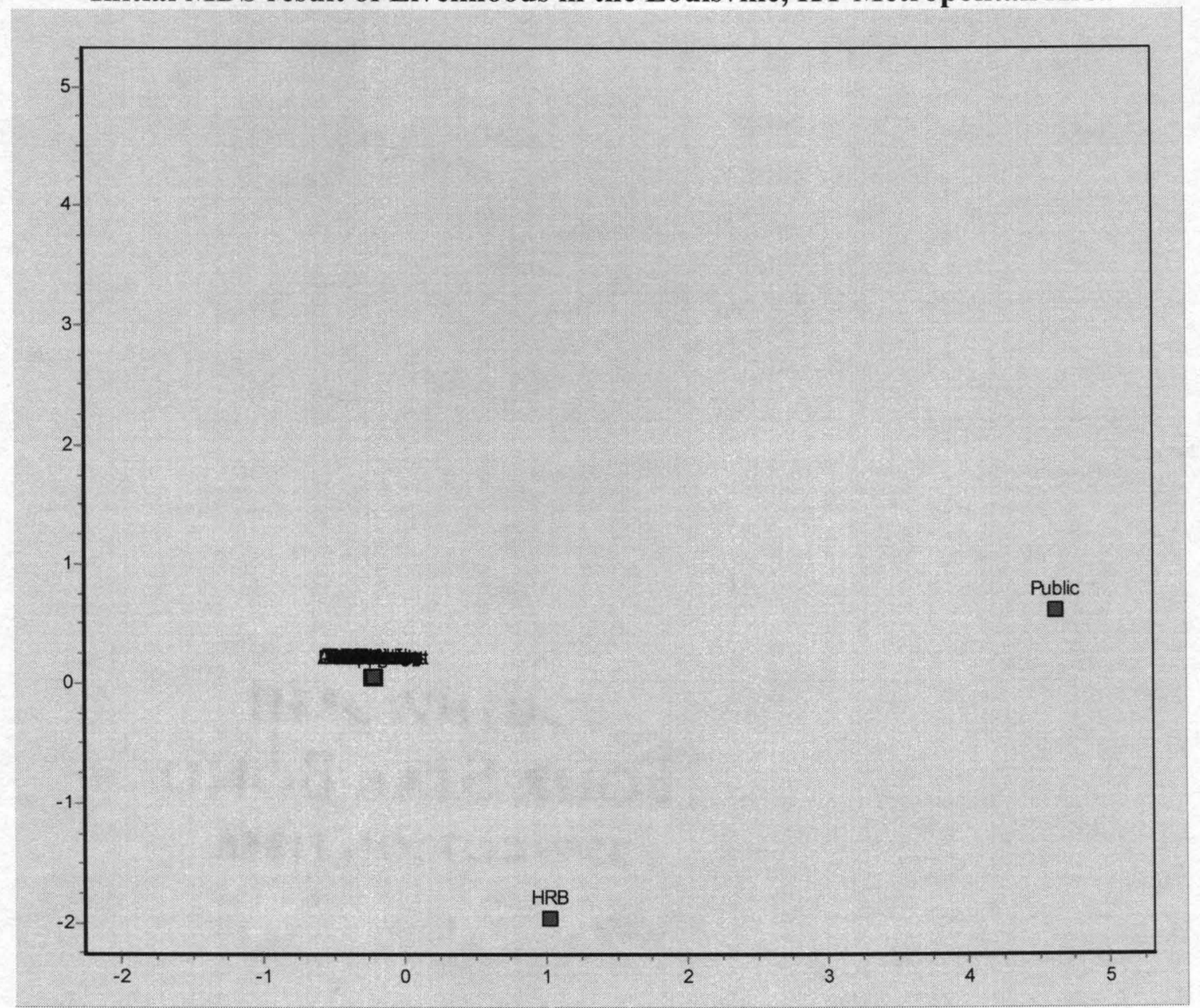

in the network - they are distinctly isolated from the other points. In contrast, the other livelihood sectors are densely compacted or tightly clustered into a small space.

Figure 4 is a magnification of the compact cluster in Figure 3. As can be observed, the result is similar to the network map but with a different organization of the points or nodes. The "neighborhood" of sectors overall are close to each other and could 
be called a cluster in and of itself. However, within the MDS results there appears to be a tighter cluster composed of hospitals, development, law, property-investing, non-profit, and finance. Mental health and government were also on the outside of the cluster.

\section{Figure 4}

Magnification of the Cluster of Livelihoods in the Louisville KY Area

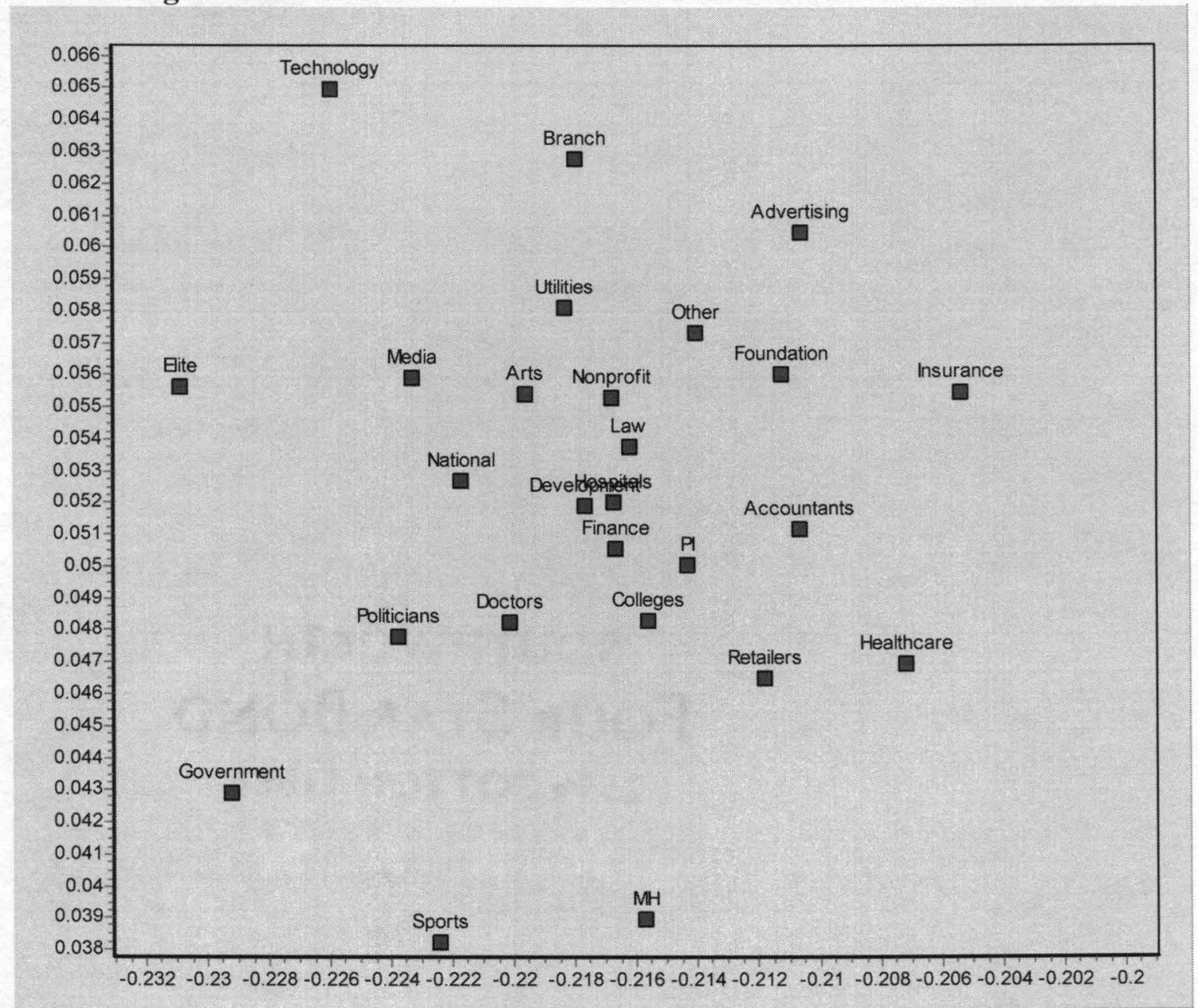

Analyzing further, it is observed that the hospitals and development sectors are practically on top of one another with law and finance being the other closest, adjacent sectors. There are no clean or neat dimensions evidenced in the MDS map. At best, the proximity of the law, hospitals, and development sectors appear to reflect their higher 
Table 13

$\underline{\text { Non-Metric MDS Coordinates of Livelihoods in Louisville Area (stress }=\mathbf{0 . 0 0 2})^{\mathbf{2 1 3}}}$

Sector

Accountants

Advertising

Arts

Branch

Colleges

Development

Doctors

Elite

Finance

Foundation

Government

HRB

Healthcare

Hospitals

Insurance

Law

MH

Media

Mental

National
MDS Coordinates

\begin{tabular}{lc}
\hline & 2 \\
-0.198 & 0.114
\end{tabular}

$-0.219 \quad 0.104$

$-0.207 \quad 0.116$

$-0.214 \quad 0.123$

$-0.208 \quad 0.105$

$\begin{array}{ll}-0.207 & 0.109\end{array}$

$\begin{array}{ll}-0.205 & 0.103\end{array}$

$0.282-1.097$

$-0.210 \quad 0.108$

$\begin{array}{ll}-0.217 & 0.112\end{array}$

$\begin{array}{ll}-0.196 & 0.091\end{array}$

$0.667-0.622$

$-0.192 \quad 0.111$

$\begin{array}{ll}-0.207 & 0.109\end{array}$

$-0.225 \quad 0.115$

$-0.209 \quad 0.112$

$-0.217 \quad 0.092$

$-0.202 \quad 0.119$

$-0.606-1.257$

$-0.203 \quad 0.112$

${ }^{213}$ The reader is reminded that these are the distances between points. The scaling as noted earlier is arbitrary and not like a regular interval variable based on a specific metric. 
(Table 13 continued)

$\begin{array}{lll}\text { Nonprofit } & -0.211 & 0.114 \\ \text { Other } & -0.207 & 0.119 \\ \text { PI } & -0.211 & 0.105 \\ \text { Politicians } & -0.202 & 0.101 \\ \text { Public } & 4.848 & 0.241 \\ \text { Retailers } & -0.198 & 0.105 \\ \text { Sports } & -0.208 & 0.088 \\ \text { Technology } & -0.204 & 0.133 \\ \text { Utilities } & -0.213 & 0.116\end{array}$

eigenvalues as evidenced in the Bonacich centrality results. Furthermore, as noted earlier, the similarity of MDS depiction with the Netdraw routine results would suggest that there is a cohesive neighborhood of livelihood sectors.

Validity of MDS results

To support the validity of the MDS findings, Table 13 is offered with the MDS coordinates along with the "stress" results. Stress is either an indication of goodness of fit (www.statsoft.com/textbook/stmulsca.html) or "a measure of badness of fit" (Hanneman and Riddle, chapter 13). The stress score was 0.002 in 50 iterations. The extent of significance of stress scores varies among the different authors. Borgatti noted that a map with "non-zero stress" is distorted." However, the rule of thumb that Borgatti suggests that any stress score under 0.1 is "excellent and anything over 0.15 is unacceptable" (http://www.analytictech.com/borgatti/mds.htm). Therefore, the stress score of 0.002 indicates that the fit is excellent with little distortion of the distances 
between the points, especially with regards to the closeness of some points. The MDS results are therefore a valid representation of the positioning of the livelihood sectors in relation to each other. What we can conclude from the MDS results is that the livelihood sectors of development, hospitals, law and finance are closely connected to each other along the lines of the measures of centrality in the network. Furthermore, the network map created by the Netdraw routine was supported. There is cohesion among certain livelihoods within the network, while other livelihoods are outsiders.

\section{Generalizing the MDS results}

As mentioned above, there have been few studies of a community power structure using MDS. The above cited studies (Laumann and Pappi and Galaskiewicz) ${ }^{214}$ were identified as utilizing this method at the community level. The MDS results here have similarity to Galaskiewicz's (1979) smallest space analysis (SSA-1) on an anonymous Midwestern community which supports generalizing these results.

According to Galaskiewicz, SSA-1 is a MDS "routine that maps points in a Euclidean space as a function of their estimated proximities on some criterion variable." This particular routine also maps points in terms of a "centroid"215 (p.1351). The criterion variables of the different MDS/SSA-1 analyses were money, information, and moral support. Galaskiewicz and his research team gathered the information for the data points through elite interviews to determine transfers of money, information, and support among the organizations in the community.

In Galaskiewicz's analyses on the networks based on the money and support criteria, there was similarity of results in the types of sectors connected with healthcare

\footnotetext{
${ }^{214}$ Laumann and Pappi (1973) used a MDS/SSA-1 analysis on a German community

${ }^{215}$ A centroid is a center point that is typically the averages of corresponding coordinates of the given set.
} 
organizations. In the "money network," both the private and public hospitals in this community were in close proximity to the local banks, the local college, the chamber of commerce, the newspaper, the radio station, and the United Way (p.1353). A similar result was found in his "support network" but the state university in the town was in closer proximity (p.1355). Galaskiewicz's variance was in his "information network" where the information was arranged to the types of activities "than auspices" (p.1352). ${ }^{216}$ The salient point is that Galaskiewicz's MDS/SSA-1 results also support a growth coalition type constellation of organizations being connected with healthcare-especially hospitals, which supports that the results of this chapter can be generalized.

\section{Analysis and conclusion}

This chapter is the first known attempt to use the techniques of social network analysis (SNA) to study the growth machine thesis as suggested by Whitt (1989). This chapter has argued that there is evidence through SNA to support the empirical portion of the growth machine thesis as an explanation of the healthcare political structure in Louisville. This chapter has been an exploration of a snowball sample with SNA tools in the UCINET 6 software package to describe the leadership patterns of healthcare in the Louisville MSA and to determine whether it resembles the growth coalition defined by Logan and Molotch. The dataset consisted of board members and officers from hospital organizations and other livelihoods (business, government, non-profit) in Louisville gathered in 2005 and 2006. This chapter in general sought to answer five questions pertaining to the argument.

\footnotetext{
${ }^{216}$ Galaskiewicz's information network was according to the types of problem-solving activities. Healthcare agencies were not in the center, but off to the left amongst themselves. City government and the United Way, media, and business associations were in the center of the network in this case. (p1352, p. 1356).
} 
The first question to test the growth machine thesis was whether there was a coherent network governing Louisville healthcare. The answer is "yes" and is elaborated in the answers to questions two through five.

The second question for exploration is who are the central individuals in the network that is healthcare political structure? The Bonacich centrality routine identified the foremost central individuals in the network. While anonymity was maintained in keeping with institutional research board standards, the livelihoods of the individuals were identified because the livelihoods are markers of the growth machine thesis. ${ }^{217}$ The tables show that here is a strong connection between the growth machine apparatus/growth coalition and the hospital organizations. So, overall those actors involved in economic development activities are central to the network of local healthcare politics.

The third question is what are the central organizations in the network that is the healthcare power structure? Clearly, GLI, which is an economic development organization, was overwhelmingly central in the network. Running a test by removing it from the dataset removed most of the original top-20 individuals. The Frost Brown Todd law firm was next central. Through the aforementioned test combined with the MDS results, Frost Brown Todd appears to be interlocked with GLJ and Jewish Hospital Health Services, which explained why they both subsumed GLI's centrality in the test. As demonstrated in table 7 , the list of the 20 most central organizations was dominated by locally dependent, growth coalition entities in addition to the major hospital organizations.

\footnotetext{
${ }^{217}$ According to University of Louisville Human Subjects Protection Program officials the individuals in the centrality results were the subject pool for the field interviews and their identities are to be protected.
} 
The fourth question is whether there are any coherent elite clique or inner circle in the network center? The null hypothesis in this case is that the most central actors would not be connected in unique cliques or exclusive groupings of actors. There was one clique with a high average eigenvalue that indeed had a significant number of the 20 most central individuals. There was a second clique of lesser average value with some redundancy from the first clique of the 20 most central actors, but it included other unique individuals. Therefore, the answer to this question is "yes."

The fifth question is where do the growth coalition livelihood sectors as whole subgroups fit in the network? The analysis of individuals and organizations was not useful in answering this, but through analyzing sectors, the "Netdraw" routine and the MDS routine in the UCINET software package both came up with similar results indicating that that there is a set of sectors in control. The MDS results suggested the evidence of a central affiliation of hospitals, law firms, and economic development organizations. Furthermore some livelihood sectors are distinctively not in this network, and some livelihoods (especially doctors) are distinctively on the fringe of the network and not central and in power (contrary to Dye's 1973 statement cited in chapter I). So, yes, there appears to be a coherent network governing Louisville healthcare.

At the most basic level, a tendency is found for a particular group of elite actors from particular sectors to be at the center. In the SNA discipline, a reasonable conclusion is the elite actors are the ones making decisions and are in control. Furthermore, the steep gradient in eigenvalue scores suggests that the individuals and organizations at the center of the network are relatively few in number, giving added significance to the term "elite." 
The livelihood sectors of these same individuals and organizations continue to manifest as significant in each analysis. These same sectors are connected with each other (especially hospitals, law and development). There is a significant collection of growth coalition livelihood sectors coherently relating to each other.

The Galaskiewicz SSA-1 results suggest a generalizability of the MDS results. While his overall research intent was different, Galaskiewicz found similar alignments between hospitals and other growth coalition organizations in a Midwestern town in the 1970's. Hospitals were in closest proximity to the banks and colleges/universities, and media outlets. Hospitals were dependent on growth coalition sectors for money and support according to his results.

The Galaskiewicz results give pause to consider that while policy network analysis has by history focused on inter-organizational analysis, getting the overall picture of a community can mean going one more rung up the proverbial ladder of abstraction-in this case network analysis by livelihood sector. This seems crucial in terms of trying to draw generalizations about the place-based aspect of healthcare politics. Different communities have different compositions of institutions and further examination of livelihood sectors by SNA could provide insight as to patterns in healthcare governance in future research of other communities despite institutional variances from locality to locality.

Thusly, SNA has demonstrated in four ways that the local healthcare political power structure in Louisville Kentucky is dominated by locally dependent individuals and organizations that comprise the growth coalition. They are central in the network and seem set apart by themselves. Furthermore, a community-wide picture was obtained 
through livelihood sector-level analysis. There is strong evidence that locally-dependent elites and sectors suggested by Logan and Molotch are central in the network and closely related to the largest healthcare systems.

As a closing disclaimer—echoing the earlier critique the, SNA results should be looked at as a general map of the network structure. The connections between growth coalition sectors and healthcare have been established but should be viewed as reciprocal linkages since they do not indicate flows of power per se. Furthermore, as suggested earlier by John that some political leadership is ceremonial and not actual, the SNA results cannot stand alone. The centrality results suggest where the power lies, but how the parties conduct their relationships and engage in political activity cannot be told merely through the structural analysis.

To confirm whether there is a growth machine apparatus, the next questions that arise are those that pertain to "agency," or human activity. Specifically what is the agenda of these actors? Do they behave like the "growth coalition?" Those questions will be addressed in the next chapter. 


\section{CHAPTER VII}

\section{RESULTS OF ELITE INTERVIEWING}

\section{Introduction}

This chapter builds upon the picture of healthcare politics started in Chapter VI.

Chapter VI on social network analysis (SNA) indicated the existence of a network structure containing central figures in unique cliques. It also reported that there is an affinity for hospitals, lawyers, and development figures to be closely connected. Through elite interviewing, this chapter will explore the agency or human action aspect of local healthcare politics.

The basic questions answered through interviews include the following:

- Who are the actual local power brokers?

- What is their agenda?

- What are their interaction patterns?

- What political insights exist in the way the Louisville healthcare organizations interact in a chaotically enmeshed ${ }^{218}$ type of relationship where they litigate against each other or challenge each other in front of the state certificate of need (CON) body but work together on other matters?

\footnotetext{
218 "Chaotic enmeshment" is a family therapy term referring to a family structure where the family relationships are overly close with poor interpersonal boundaries with regular conflict and soap-opera type drama, but members will still defend each other against outsiders. The severity of the conflict and chaos
} 
Within the case study design, these and other questions help paint a picture of the complex political reality at the city-wide level or metropolitan-wide level of the Louisville, Kentucky Metropolitan Statistical Area (MSA).

The use of elite interviews is a traditional practice in political research. Hunter (1953) used elite interviews after his network analysis to gain a fuller understanding of Atlanta's power structure and elite communication patterns. ${ }^{219}$ If the interview results affirm the SNA results, then the hypothesis that the growth machine thesis describes local healthcare politics is supported.

If there is support for the growth machine thesis there also will be evidence that growth is the agenda of local healthcare politics. Alternative political agendas include: quality of services, equitable distribution of services and preservation of the status quo. If growth is not the political agenda, then the growth machine thesis as an explanation for local healthcare politics is rejected.

Decision-making patterns will support or disprove the growth machine thesis as an explanation of local healthcare politics depending on whether there is elite or pluralistic negotiation and decision-making. The pertinent task here will be getting a sense of how many individuals are involved in local healthcare political decision making? If there is a pluralistic pattern then the hypothesis is rejected, but an elite pattern will support the hypothesis.

varies from family to family. A chaotically enmeshed family is in contrast to a rigidly enmeshed family where there are poor interpersonal boundaries, but no family conflict or latent or repressed conflict.

219 One of Hunter's most intriguing chapters based on interviewing (similar to this chapter) was titled "The More Private Aspects of Power" (pp.171-206). Hunter's approach of reputational study is a paradigm of identifying who make the decisions in a community. Hunter then approached the individuals who had the reputations of being in charge in the community for interviews. 
Before engaging in SNA, there was prima facie evidence that there were network interlocks in the governance of the University of Louisville Hospital (formerly known as Louisville General Hospital). Since 1996, this hospital has been governed ${ }^{220}$ by University Medical Center Inc (UMC)—a 501c3 charitable nonprofit organization.

Between 1996 and 2007 UMC was a management consortium of Jewish Hospital, Norton Healthcare, and the University of Louisville. At the time of the interviews some informants disclosed that the University of Louisville had initiated termination ${ }^{221}$ of the consortium agreement. The University of Louisville wanted control of UMC. This was later publicized in the Louisville Courier-Journal as a fait accompli (Howington, 2007, July 10). After the interviews were completed, UMC had named new board members who were not part of the other hospital organizations (Howington, 2007, September 27). ${ }^{222}$ This consortium's formation, existence and break-up offer an opportunity to explore the political-economic dynamics in local healthcare politics.

There were some other questions regarding understanding local healthcare politics. These were:

- Where do the Mayor and Louisville Metro Government fit in healthcare politics in Louisville?

\footnotetext{
${ }^{220}$ The term distinctly used by the pertinent informants to describe the arrangement was "governance" not management.

${ }^{221}$ Section 26 of the original 1996 agreement between the state of Kentucky and the consortium gave the different parties options for terminating the agreement (pp.37-40). It was apparent through the interviews with the knowledgeable informants that the University of Louisville terminated the agreement for carrying out its economic development mission as commissioned by the State of Kentucky. Whether this is accurate depends on how much the termination portion of the agreement was revised from the original agreement. ${ }^{222}$ This new UMC board proved to be an elite (versus pluralistic) board from some of the same growth coalition sectors. According to the story, the new individuals appointed to the new board included one banker, one attorney, one local business executive, two non-profit executives, one utility executive, one individual who is both clergy and president of another local college, two $U$ of $\mathrm{L}$ administrators related to Medicine, one medical school professor, and one non-descript "community volunteer. A doctor from western Kentucky was also appointed. The residual members from the old board include one rentier, and
} 
- Apart from the question of UMC why do the leading healthcare organizations work together on some matters and then go as far to litigate against each other on other matters?

- How much do the interlocks matter overall?

- Who does the negotiating and where do they talk?

These questions are helpful in understanding the political processes.

Some questions pertain to redistributive aspects of local healthcare politics. These are:

- Given the high centrality and strong elite involvement in the getCare Network, why did it close? ${ }^{223}$

- Why was a hospital organization able to close a hospital in a workingclass area of Louisville and transfer all the beds to a more affluent section of town?

- Why are mental health and public health agencies in general not connected with the local political network?

These questions deal with more of the larger "why not?" question."

This chapter discusses the answers to those questions from 22 informants. Most of the informants were central in the SNA results as discussed in the previous chapter. Some informants with less centrality were interviewed based on their positions and expertise in the community to give informed perspectives about the local political situation.

the U of L president. The "community volunteer" was actually a former Humana executive who worked in the hospital division of Humana before Humana spun off its hospital business.

${ }^{223}$ The question of sustainability seems more appropriate as "failure" is a matter of program evaluation. This study is not a program evaluation. 
This chapter argues that there is support from the elite interview results for the growth machine thesis as an explanation of local healthcare politics in Louisville Kentucky. There is support for the network interlocks having meaning, but not all of the interlocks have the same significance. Informant responses provide sufficient evidence to support the hypothesis.

This chapter will be structured as follows. It will discuss the methodology for selecting the informants, present a thematic discussion of the informant answers, and close with summations and conclusions.

A cautionary note is given. This chapter is about theory behind the information given by the informants. It is meant to advance knowledge and point out areas for future useful research. It is meant to provide conclusions that can be generalized outside of Louisville about local healthcare politics and is not meant to be an expose of the local political actors and issues despite the exploration of details of local issues. Therefore, the remainder of this chapter will be written in a manner to protect the identity of the informants.

\section{Informant Selection and Conduct of Interviews}

This section will discuss the method for systematizing the interview process. The intention was to provide an orderly and logical method for selecting informants. The idea was that the central individuals in the network have access to information. They also have opinions of the communication patterns and the agendas in local healthcare politics. As with much of field research in the natural environment, not all the individuals who were identified as central actors in the SNA were responsive or cooperative. There was 
also some change in direction of informant selection as the field interviews progressed. The interview method also was changed to shape the informant responses.

Two authors were helpful in guiding the interview process. Dexter's (1970) Elite and Specialized Interviewing was useful in conceptualizing how to conduct the interviews. It was used as a guide for devising the interviews and getting clarity for approaching the interview event. A work cited in the scholarly literature review, Conant (1968) conducted field interviewing of civic leaders pertaining to local healthcare issues. Conant wrote "Civic leaders who are not involved in health agencies are usually hard put to discuss knowledgeably any local health issue" (p.17). Similar experiences were had in approaching potential subjects given that they had rotated off boards in Louisville before the interviews were conducted-they were reluctant to talk. Dexter provided a map on how to ask the right questions while Conant provided generalization to the encountered reluctance.

The initial selection of informants was intended to be a logical step from the SNA results. One goal was to interview as many of the individual actors in the top 20 Bonacich eigenvalues as possible. The other goal was to interview as many of the members of the two most central cliques. Some allowance was made to interview informants that had direct knowledge of the Falls Region Health Council/Louisville Area Health Facilities Council. This logical pattern of informant selection was in keeping with the case study design.

However, as evidenced in most field research, there are various types of interference in the environment that are threats to validity. Some prospective informants made referrals to lieutenants. Some just said no. Some did not return phone calls or 
respond to letters. Also, as interviews were conducted, other potential informants were identified as a mover and shaker and thus knowledgeable of the overall political situation despite lack of centrality.

For the most part, the interviews were scheduled as orderly as possible. The interviews took place between April and August 2007. The interviews were not scheduled all at one time, but as some interviews were finished, other potential informants were approached.

\section{Solicitation Method}

The writer solicited informants in three ways. The primary approach was by phone call. The secondary manner was by email. One unsuccessful attempt was made to contact by mail a prospective informant who did not have a listed phone number or email address. Where applicable, the prospective informant was informed of the selection process based on the SNA results. A total of 33 subjects were approached. There were 19 acceptances by the identified informant and three referrals to lieutenants. There were two last minute cancellations with failed attempts to reschedule. There were 22 interviews conducted.

\section{Conduct of the interviews.}

The type of interview being conducted was an "elite interview." Dexter (1970) informed the conduct of the interviews. Dexter wrote "It is an interview with any interviewee and stress should be placed on the word 'any' - who in terms of the current purposes of the interviewer is given special, nonstandardized treatment" (p.17). For Dexter the stress is placed on the interviewee's definition of the situation and what the interviewee considers to be relevant. Furthermore, in this style of interview, the 
interviewee is encouraged "to structure the account of the situation" (p.17). In other words, this style of interview has some ethnographic properties, as what is sought is the informant's perspective of the situation.

All but one of the interviews was in person. Due to health problems one informant was unable to meet face to face, but was willing to talk over the phone. ${ }^{224}$ The majority of the interviews took place at the workplaces of informants. One interview was conducted at the writer's workplace in a location where privacy could be maintained.

All of the interviews were recorded on audiotape. All the informants gave permission for the interview to be taped and were aware that the interview was being taped. A micro-cassette tape player was used for the in-person interviews while a phone coupler was used for the phone interview.

All informants were given a preamble letter before the interview. ${ }^{225}$ The letter followed the suggested format by the University of Louisville IRB that stated the rights and privileges of the informants. This preamble letter was changed after the first interview to include a more stringent clause about the protection of the identities of the informants. The aim was to be as consistent as possible with all informants and to enhance the potential of acquiring meaningful information in line with the purposes of the research.

The average interview generally lasted one hour. Some informants had less time to give, and so questions were prioritized based on the informant's livelihood and their position in the network. One assumption in conducting the interviews that was quickly

\footnotetext{
${ }^{224}$ While telephone interviews were not discussed in Dexter, conducting one seemed appropriate for the purposes of the research.

225 The informant interviewed by phone was sent an email and a letter by regular mail with the preamble text.
} 
debunked was that all of the actors had the same interest, same knowledge, and same passion of involvement- - they did not and therefore the interview length was dependent on the informant's knowledge and willingness to answer the questions.

Typically, the interview started with a general, open-ended question about the informant's initial conception of the term "urban health politics." A follow-up, openended question included Lennarson-Greer's definition of "urban health politics." From there, the writer asked the questions based on the flow of the interview.

\section{Interview Questions}

The list of planned interview questions arose from three sources. The first source of the questions was the knowledge base of urban political economy with the initial prima-facie observations of board-interlocks combined with legal challenges between the organizations. The second source of questions was the SNA results. The third source of questions for later informants was from the answers of earlier informants. Questions were changed as the interviews progressed and more information was learned about the environment.

\section{Process of Changes in Interview Questions}

While there was an attempt to be "ruleful" or orderly in the manner of interviewing informants along the lines of Dexter's definition, the process of asking appropriate questions and understanding what questions would work was Socratic. Some education had to be given to the informant as to what the researcher was looking for. The term "healthcare politics" engendered answers in terms of government public health issues. Follow-up questions were asked when informants were confused or gave unique 
answers. Effort was made to be consistent in the phrasing of the questions to the first 20 informants to elicit valid responses to the questions. ${ }^{226}$

\section{Preliminary Ethnographic Observations}

Dexter noted that concentrating on a few informants may help an "investigator to acquire a better picture of the norms, attitudes, expectations, and evaluations of a particular group" than could be obtained through less intensive observations or many less intensive interviews (p.8). Some conclusions can be drawn about the ethos of this group of informants.

While some were relaxed, most of the informants presented with guarded affect and posture. $^{227}$ The first informant requested additional assurance that the tape of the interview would be protected and destroyed at the conclusion of the study. In aiming to be consistent, the preamble letter was changed to reflect that identities would be protected and that anonymity would be maintained in keeping with the IRB policies and Social Science research principles. Effort was made to make the informants as comfortable as possible and reassure informants that human subject protection standards would be followed. $^{228}$

Even with the assurance of confidentiality some informants declined to answer some questions without any explanation. Some informants made reference to the confidentiality pledge throughout the interview as an introduction to a number of their

\footnotetext{
${ }^{226}$ What is meant as a valid response is that the informant at least said that they did not have an answer for the question. The last two informants were sought for specialized knowledge on a topic.

${ }^{227}$ One of the potential informants referenced in footnote $\# 4$ said that the organization boards had confidentiality rules.

${ }^{228}$ Informants would often ask, "Have you talked to this person?" They were told that the investigator could not reveal the identities of any informants just as much as their identity was going to be protected.
} 
comments regarding particular topics, which suggested that the subject of local healthcare politics is a delicate matter.

\section{Thematic Summations of Answers to Questions}

This section will discuss the themes of the informant answers. This thematic approach was chosen to protect confidentiality of the informants and allow for the varied the quality of the informant answers. ${ }^{229}$ The variances were due to: the informant's unique network position and accessibility to information, the informant's point of view, and the informant's comfort level. This thematic approach means that two or more informants gave similar answers. ${ }^{230}$

Who? What? Where? How? . . and for What?

This section will be organized as follows. It will first discuss informant identification of the main actors in local healthcare politics in Louisville. This includes informant perspectives on Greater Louisville Inc. and Louisville Metropolitan

Government. Then informant comments on the Louisville agenda in local healthcare politics are reviewed. The patterns of how the actors communicate will then be explored. The political aspects of the University of Louisville Hospital and the Louisville Medical Center Development Corporation will be discussed. This section also reports informant responses about the "getCare" network, the closing of Southwest Hospital, and the lack of interlocking or network between the private sector and public sector health organizations.

\footnotetext{
${ }^{229}$ Not all informant responses were of the same quality that was suitable for quoting.

${ }^{230}$ The assumption here is that the preservation of confidentiality provided some control and that the purposive sample of informants was not contaminated since the informants were not aware of each other's participation.
} 


\section{Who are the Players in Local Healtheare Politics?}

The question asked informants which was pertaining to the identification of movers and shakers was usually worded as: Specifically, who do you think the movers and shakers are in local health political decision-making in Louisville? There were a number of different ways in which to conceive the information about the players. The informants identified players in the form of organizations, individuals, and sectors.

$$
\text { Individuals }
$$

The informants said that movers and shakers in healthcare politics come from one of four groups: health administrators, educational figures, political figures, and board chairs of hospital organizations. The health administrators were both local hospital organization executives and executives in the Kentucky Hospital Association. The hospital executives named were both presidents-CEO's and particular lieutenants who had distinguished themselves. Occasionally, the public health administrators were named. The educational figures most often named were the president of the University of Louisville and the dean of the University of Louisville Medical School. Both Louisville Mayor Jerry Abramson and the Louisville Metro Department of Health and Wellness Executive Director, Adewale Troutman are the primary government figures. Informants repeatedly identified three board chairs (two are bankers and one is an accountant). While the list was not inclusive, the informants identified the movers and shakers to be individuals who were both community elites and executives.

A follow-up question was: Do you think the movers and shakers report to a higher power (person or body) within the city of Louisville? The informants consistently denied that there was one foremost power broker or opinion leader. Informants identified 
two individuals: David A. Jones Sr., co-founder of Extendicare/Humana, and Henry "Hank" Wagner, retired president of Jewish Hospital Healthcare Services, as being opinion leaders in the past, but that no one has since been as powerful. So, by deduction at the time of this writing, there is a group of individuals who appear to be movers and shakers, with no one more powerful than the others.

$$
\text { Organizations }^{231}
$$

Informants overall identified a short list of organizations that are movers and shakers. The leading three leading hospital organizations (Norton, Jewish, and Baptist) were most identified leading organizational actors. The University of Louisville was identified next in terms of frequency. Informants repeatedly identified the proprietary organizations: Humana ${ }^{232}$, Kindred and Rescare ${ }^{233}$ as a third tier. A number of informants identified the Family Health Centers as a player. Given the list, overall informants saw the hospital organizations as the main organizational players in local healthcare politics.

\section{Sectors}

Some informants framed answers in terms of sectors. One informant said, "If you are talking about public or private, there's a whole different cast of characters." Another informant said that the public sector is "such an expansive area. I see it bouncing around at different points in time." Informants most frequently identified the Family Health Centers and the Louisville Metro Health Department as the main public sector actors.

\footnotetext{
${ }^{231}$ One respondent also said "I may be using the wrong term, the unions or the company, Ford, GE, UPS, are major players in this, and then you get into the healthcare companies themselves . . like Humana, Ventas."

${ }^{232}$ As noted elsewhere Humana was first a proprietary healthcare organization that then evolved into health insurance and then divested itself of hospitals.
} 
Informants overall framed the private sector in terms of proprietary and non-profit players. The non-profit Jewish, Norton, and Baptist organizations were identified as definite movers and shakers. The proprietary actors (Kindred and Humana) were not seen as central to local healthcare politics, as both have a national focus and minimal local involvement. Humana was identified as the exception when it had owned three Louisville hospitals and had the management contract for the University of Louisville Hospital for 13 years.

Where are the doctors?

Informants did not identify doctors when asked the open-ended question about movers and shakers. Informants consistently did not answer until asked the specific question: How have you seen the role of doctors in the political realm?

\section{The Role of Doctors in Terms of the Overall Community}

The informants as a group confirmed that physicians as a group are not involved in the local political process or are marginally involved at best. Informants consistently said that physicians do not wield power or influence over healthcare goals in the community. There was a recurrent theme that while there was the existence of the Jefferson County/Greater Louisville Medical Society, ${ }^{234}$ there was not strong organization among physicians at the community level. They have tended to be quiet unless they have strong opinions on a particular political issue.

Informants consistently reported that physicians have more political power at the facility or institutional level of the hospitals. Physicians are advisors and economic

${ }^{233}$ Rescare is a Louisville-based proprietary organization that primarily specializes in running residential care facilities across the United States. The residential facilities historically have been called "group homes." 
drivers as they direct business to the different hospitals. One informant said that doctors did not have a strong say until it was discovered that hospitals could "construct a lot of profit under the guise of doctors' offices" and that doctors are cheerleaders for a hospital getting new equipment already in use at other hospitals. Another informant said,

The heart surgeons in town have put us on the international map, and so have the hand surgeons. We're known internationally as the best hand surgeons in the country. And we're known as being some of the best heart surgeons in the country. That's pretty impressive for Louisville Kentucky when you have an artificial heart put in and that tagline in the newspaper is Louisville Kentucky, but when Laman Gray ${ }^{235}$ asks for something, you try to accommodate him.

Informants repeatedly described physicians as independent business people who

sell their time and can influence placement of facilities. One informant said

So the suburbanization of some of these practices is as much for their convenience. Even to the point where Norton is close to the point of shutting down of all delivering of babies downtown. When you look at where geography is, downtown is still a good place for a lot of people to have babies. They thought that everyone is dying to go to Suburban but if you put all the delivery out at Suburban, then everybody will go because they don't have any choice. What have you proven about the Marketplace, the OB-GYN's that have to wake up in the middle of the night were fussing about having to do that extra 15 -minute drive downtown, that's all it was. For some types it is not an issue, but for that particular group it is.

Another informant said a specialty practice that makes significant revenue for a particular hospital has much more pull and can extract concessions.

A change in the trend of doctors as independent business people was noted by a number of informants as hospital organizations have been hiring physicians (especially family practice doctors) as employees. The employed physicians are required to refer

\footnotetext{
${ }^{234}$ Historically, the Jefferson County/Greater Louisville Medical Society has facilitated a process whereby a physician can apply for credentials at all the desired facilities in town through its auspices.

${ }^{235}$ Laman Gray M.D. is an internationally-known heart surgeon, and Professor at the University of Louisville Medical School. He, along with Rob Gray, MD implanted the Abiocor Artificial Heart in a number of patients on a trial basis at Jewish Hospital in 2000-2001. He also performed the first Heart Transplant that was performed in Kentucky.
} 
within the hospital organization and therefore hospital organizations are controlling the referrals under the guise of an established continuum of care. One informant declared that this is a 'de facto' closed staff system in place in the various hospitals and the doctors are ceasing to be independent business people with mobility throughout the city to practice in different hospitals. ${ }^{236}$

\section{The Role of Doctors in Terms of the University of Louisville Medical School}

Some informants identified the Louisville Medical Center as an exception in terms of physician political power and influence due to the presence of the University of Louisville Medical School. A number of informants identified the dean of the University of Louisville Medical School as an agenda-setter. A number of informants said that the various University of Louisville Medical School department chairs also have influence over the placement and operation of indigent care services. However, the responding informants said Medical School's influence is limited and it stays within the Medical Center and does not extend to the larger community. ${ }^{237}$

Where is Greater Louisville Inc?

Informants generally did not identify Greater Louisville Inc (GLI) as a mover and shaker. ${ }^{238}$ Few informants mentioned GLI's Health Enterprises Network as significant. This was significant in light of the SNA results placing GLI at the center of the network. So, three specific questions were asked along these lines:

\footnotetext{
${ }^{236}$ A number of informants made reference to Louisville in general having "open-staffing" where if a doctor completed all the requisite paperwork through the Medical Society, they could have privileges at any hospital in town. With the physician's as employees movement gaining momentum this is changing. ${ }^{237}$ One respondent suggested that as part of an overall agenda by the University of Louisville Medical School to build the "U of L" brand, it is looking to be a full competitor with Jewish, Norton, and Baptist. There is some news coverage to that extent where $U$ of $L$ is contemplating outpatient facilities outside the downtown Howington, (2007 July 12), but no other informant confirmed this.

${ }^{238}$ Some informants identified the Health Enterprises Network, which is a "network" of GLI, but few spontaneously mentioned GLI or the Health Enterprises Network as a player.
} 
- Many of the hospital board members and administrators in some shape or form are members or directors of Greater Louisville Inc. Does this have any implications in your eyes for the way healthcare in Louisville goes?

- Does Greater Louisville Inc have any significant influence in the way decisions are made in this area?

- What role does GLI play in healthcare?

There were two lines of answers to these questions. The first category was that GLI was not involved in healthcare decision-making. The second category of answers was yes, but it only had to do with economic development.

Many informants said that GLI did not have a role in healthcare, noted that GLI had a significant existence but nothing more. One informant said, "To be honest. If GLI is involved in healthcare, I don't know about it. "Another informant said, "I never would have thought of that. This company's a member of GLI. I've received their mailings. I don't see any connection. "A third informant said,

The organizations like GLI--they like to think that they are more important than they are. I got out of the chamber years ago. I was on the board of the chamber. So, I don't think that they have all that much influence. They're present.

A fourth informant said "I really don't include the health network. The Health Enterprises Network ... that's been a relatively ineffectual organization. "A fifth respondent offered what may be a harmonizing statement:

You have a group of people in town who are just very active in the community. They're movers and shakers. And if they're going to be movers and shakers, they're going to be on GLI and they're going to be on Jewish Hospital.

The second group of informants did recognize GLI as a player, but not necessarily a strong one. One informant said that "GLI is clearly responsible for driving the 
economic agenda and healthcare has become a major player in that." Another informant said that GLI's presence is "very light" in that it has never been a source of leadership but performs a "chamber of commerce function" that promotes the research agenda but does not engage in healthcare services planning policy. A number of other informants pointed to healthcare in Louisville as a large economic sector with significant manpower needs, and it is dependent on GLI to help develop the talent. Lastly, there was a theme of having well developed healthcare services and attracting medical research firms to assist in expanding the economy. Synthesizing the two groups of informant responses, it can be concluded overall, that while overwhelmingly central, GLI as an organization has potential to do so but informants do not experience it as an active participant in healthcare politics. $^{239}$

Two informants cited the Boyle Report ${ }^{240}$ of 1996 as a source for understanding Louisville's healthcare agenda. This report identified Louisville's biomedical sector as an area for economic growth. GLI's predecessor, the Louisville Area Chamber of Commerce had commissioned the Boyle Report. This suggests a pattern that GLI and its predecessors had started a vision that was carried on by other actors like the Barnes report of 1945 and the Hamilton Report of 1948 led to the formation of the Medical Center. $^{241}$

Where are Local Government and the Mayor among the Players?

The informants did not consistently name the Mayor of Louisville and municipal/metro government as actors in healthcare politics. The question asked to elicit

\footnotetext{
${ }^{239}$ Logically GLI has members who are active in healthcare politics including hospital executives.

${ }^{240}$ The formal title of this was Economic Development Strategy for the Greater Louisville Region.
} 
this information was usually worded as: In your opinion, what is the Mayor's and Metro Government's ${ }^{242}$ primary role in the healthcare system? The answers are as follows.

\section{The Mayor}

Informants generally saw the current Louisville Mayor, Jerry Abramson as more involved in economic development issues pertaining to healthcare and not in redistributive issues and not been involved in charitable fundraising except for Kosair Children's Hospital. Informants recognized him as the originator of the Louisville Medical Center Development Corporation, which has an economic development mission. Informants also saw Mayor Abramson as a passive, but well informed behind-the scene player. The Mayor has a reputation as being a supporter and cheerleader of development. Some informants said that the Mayor will talk to the heads of the different hospital organizations and influence agendas, but he does not wield control over the hospital organization agendas. One informant said that there does not appear any "mechanism" set up for the Mayor to be involved in identifying health needs in the community.

While the Mayor is seen more as an economic development figure, informants identified his two public health interests as the Quality Care and Charity Trust (QCCT) ${ }^{243}$

\footnotetext{
${ }^{241}$ As discussed in the historical review, The Barnes Report of 1945 and the Hamilton Report of 1948 were both commissioned by the Louisville Area Development Association in its efforts to create the Louisville Medical Center and are discussed in detail in the historical review chapter.

${ }^{242}$ The term "Metro Government" is being used in lieu of the 2003 consolidation of Louisville and Jefferson County, Kentucky governments.

${ }^{243}$ The QCCT is the principal funding mechanism for indigent care at the University of Louisville Hospital. The QCCT itself is a $501 \mathrm{c} 3$ non-profit organization administrated by the office of the Controller of the University of Louisville. The QCCT has been a cooperative, public funding source that the University of Louisville hospital bills on a monthly basis for indigent patients residing in Jefferson County. A number of informants identified the QCCT to be an important but sensitive issue According to informants the QCCT contribution is a matter that is negotiated at a high political level within the city. The Mayor and the University of Louisville President directly negotiate the city of Louisville's contribution to the QCCT. The QCCT was created in connection with the Humana management contact in 1983 for the University of Louisville Hospital. As it existed in 2006, the QCCT is contractually laid out to exist until 2016. The QCCT itself is financed through a matching fund process, which has changed at least one time in its existence. Initially the money was officially a combination of local, state and federal funds enhanced
} 
and health and wellness. Informants lauded the Mayor for his wellness campaigns and his leadership in the smoking ordinance restricting smoking in public buildings and restaurants. ${ }^{244}$

\section{Involvement by Metro Government as an Entity}

Overall, the informants saw that beyond the Mayor and Dr. Troutman, the Louisville Metro (Consolidated) Government as a minor if not just a passive player in healthcare politics. One informant said,

I don't think there are even positions established that the designation or authority to really take that on beyond Dr. Troutman, and if there are positions, they're relative weak positions, I not talking individuals, I'm talking positions that have somewhat perfunctory leadership roles.

A number of informants cited Dr. Troutman's health disparities campaign as being influential, and see Dr. Troutman himself as a credible opinion leader with regard to that agenda. A number of informants said that Mayor Abramson backs Dr. Troutman in whatever Troutman sets out to do.

Informants do not see the Louisville Metro Council as a central player in healthcare politics. One informant said that while the Louisville Metro Council made the policy of the smoking ban in 2006, it was not the driver of that policy (GLI was). The Metro Council is seen as a provider of indigent care funding when it approves the QCCT

through the Disproportionate Share Fund mechanism and matched with federal Medicaid dollars. Now, the funds are strictly from the state of Kentucky and Louisville Metro governments.

There were two consistent controversies pertaining to the QCCT. The longest running controversy has related to the choice of the City of Louisville/Louisville Metro Government to not contribute its legally, contracted amount. The second controversy identified by informants pertains to UMC competing with Norton and Jewish for insured patients while being reimbursed by the QCCT for indigent care while Norton and Jewish would not be reimbursed for giving some of the same type of indigent care.

${ }^{244}$ This smoking ordinance initially prohibited smoking in all restaurants and public places with the exception of Churchill Downs--the home of the Kentucky Derby horse race. A number of informants said that the smoking ordinance got passed after Brown and Williamson Tobacco merged with Phillip Morris and left town. However, in December 2007 a judge struck down the original ordinance as unconstitutional given its Churchill Downs provision. The Mayor quickly moved and the Metro Council passed a stricter version of this ordinance including Churchill Downs. 
(however it is the mayor who is viewed as the primary negotiator with the University of Louisville in agreeing upon Metro Government's contribution). However, one informant said, "I don't think he (the mayor) has absolute power. The council is a partner".

Summation about the Players

This section reported the informants' identification of the actors in local healthcare politics in Louisville. The primary players are the heads of the hospital organizations. Within the Louisville Medical Center in the downtown district, informants also viewed the President of the University of Louisville and the Dean of the $\mathrm{U}$ of $\mathrm{L}$ Medical School as significant. Contrary to the SNA results informants do not view GLI and its "Health Enterprises Network" as players. The informants identified physicians as peripheral actors. Jerry Abramson, the Mayor of Louisville was seen as passive, but informed interested in economic development. ${ }^{245}$ Louisville Metro Government is not seen as a central player outside the activities of approving budgets and approving ordinances. However, Adewale Troutman MD, Director of the Louisville Metro Department of Health and Wellness was seen as a leader and a player who has the support of the Mayor. Overall, it can be concluded that local healthcare politics is more of a matter of informal politics versus formal government politics and that it is not pluralistic, but few individuals are involved.

\section{What is the Agenda of the Local Players?}

This section summarizes informant views as to what agenda exists in local healthcare politics in the Louisville Metropolitan Area. The question to elicit answers was: Do you think that there is any particular agenda overall in this political realm?

\footnotetext{
${ }^{245}$ Before he had his second tenure as Mayor of Louisville, Abramson was on the Jewish Hospital Healthcare Services Board.
} 
This question did not need to be asked in every interview. Some informants answered this when responding to the two opening questions. Some answered this question when identifying the actors.

Some informants answered this question at the end of the interview when the investigator discussed the growth machine thesis and asked for some reaction. Some of the respondents gave unique answers at the end regarding the healthcare politics agenda in universal terms.

Informants gave a variety of views. Two informants did not see a coherent, single agenda. Some informants saw the city agenda as a combination of the agendas of the different hospital organizations. The different organizations have their own strategic plans for growth. In this case, independent organizations being in competition cooperated among themselves when cooperation did not threaten the organizational interests. $^{246}$

Some informants identified the healthcare politics agenda in Louisville as being economic development. ${ }^{247} \mathrm{~A}$ number of informants also saw it as a matter of national and international prestige, especially given the Abiocor Artificial Heart implantation trials and the first hand transplants. One informant said that what the movers and shakers have "tried to do is brand Louisville as a healthcare community." One informant answered the specific, closing question about the growth machine thesis.

Healthcare is probably the best demonstration of it. Growth, in the mouth of a politician is a sacred sacrament. Whereas our traditional sources of growth, namely manufacturing are stumbling and foreign competition. Our best chance of

\footnotetext{
${ }^{246}$ One example of this was cooperation by the hospital organizations to make a joint announcement in May 2007 that all facilities would be smoke-free. Some informants said that this was a way of preventing turnover and transience of employees from one organization to another in order to smoke at work.

${ }^{247}$ It was interesting that a number of actors acknowledged that this was the agenda but also voiced criticism of this agenda as it led to inequities and was not a solid basis for Economic Development.
} 
growth is the growth of healthcare delivery and healthcare services--by that I mean insurance companies. These are tangible things that the politician can brag on.

A number of informants identified the University of Louisville as now the main leader in the healthcare development agenda. It has an agenda to transform the "Haymarket" site in the eastern part of downtown Louisville into a bio-medical research park. ${ }^{248}$

Besides the branding efforts, healthcare is recognized as is a major sector of the

Louisville economy and thus of political importance. One informant said,

Healthcare has been seen not only because of the services it provides, but as a way to provide lost manufacturing jobs so it is a critical service to the quality of life to the people but it's also an economic cluster that is valued by our community. So I see that city government and the Mayor driving that role as well.

Another informant called the healthcare industry in Louisville as a "hot issue" because of the amount of money and number of employees in it. A third informant said, "Our local government has a vested interest in the healthcare system continuing to grow."

\section{The Manner of Political Communication and Implementing Policy}

In the process of testing the growth machine thesis another question pertains to how the movers and shakers communicate and make decisions. The growth machine thesis in this case would be disproved or rejected if there is proof that the healthcare political decisions in Louisville are made in public forums by a pluralist majority or by elected officials. Of course this was not the case. The communication in healthcare politics was identified to be among elites on an informal basis.

The knowledge of the different informants was inconsistent. Therefore, a number of different questions were asked to understand who was talking and where they talked?

\footnotetext{
248 This was also reported in the Courier-Journal (Howington, 2007 July 12).
} 
Some informants identified the executives and not the board members who are the primary negotiators in local healthcare politics. Board members do not usually get into outside informal negotiations with board members from other hospitals on behalf of the respective hospital organizations. One informant was emphatic that there are no such conversations that take place at "Fund for the Arts" meetings or at work places. The chief executive officers (CEO's) and executive teams are the prime negotiators because healthcare has evolved into a highly complex industry.

Some informants said the hospital organization executives have conversations under the auspices of the Kentucky Hospital Association (KHA). The executives of the different organizations are on various KHA committees and have conversations in a legal context that cannot be construed as fixing the market.

However, other informants reported that the executives of the different organizations have a history of talking informally among themselves. The executives of the three hospital organizations have a history of engaging in quid pro quo with regard to different facility projects (i.e., we will not challenge you in front of the Certificate of Need board on your particular project if you do not challenge us on our project).

\section{The Matter of Organizational Interlocks and Political-Economic Tension}

Given the observation of interlocks, especially among the organizations in the Louisville Medical Center, questions were asked about their relevance. One question was: Did the interlocks give the actors coherence? A related question was: What sense do we make of the tension between competition and cooperation among the actors and organizations in light of the interlocks? 
The presence of interlocks combined with the political-economic tension in the forms of legal and market competition presents a puzzle. The linked organizations have a demonstrated history of cooperating on some matters yet at times being legal adversaries and all the while being market competitors.

Only the Interlocks in the Louisville Medical Center Matter

According to the informants with an opinion, the interlocks only mattered for the organizations in the proximity of the Louisville Medical Center. A number of the informants said while Baptist East $\mid$ Baptist Healtheare is connected through KHA and GLI, it is detached from downtown matters. ${ }^{249}$ One informant said,

I can guarantee the linkage between the Medical School and all the hospitals ... at least Norton's and Jewish is so tightly inter-woven that you can't have one person doing something without affecting the other.

Norton and Jewish are both teaching hospitals for the University of Louisville Medical School and have been for several decades.

The other interlock of question was the Louisville Medical Center Development Corporation (LMCDC). The Mayor and all the executives of the downtown hospital organizations sit on its board. The informants said that the LMCDC initially focused on signage around the Medical Center and then it focused real estate development. More recently renamed as Nucleus, it has focused on intellectual property development.

In 2007, the two sets of interlocks have broken apart for related reasons. The rest of this section will discuss the origin and breakup of the primary interlocks: University of Louisville Hospital, the Louisville Medical Center Development Corporation. The issues

\footnotetext{
${ }^{249}$ At the time of the interviews, Caritas Medical Center and Caritas Peace Center had merged with Jewish Hospital Healthcare Services into Jewish Hospital St. Marys Healthcare. Prior to November 2005, they were like Baptist Healthcare and not in the interlocks.
} 
include: why the interlocks were started and terminated, the extent of their impact, and the contributing environmental issues.

The University Medical Center Incorporated (1996-2007)

For more than 11 years, there had been an enmeshment of interlocks between the Jewish and Norton organizations in the roles as governors (versus board members) ${ }^{250}$ of the University of Louisville Hospital. Their affiliation with the University of Louisville to govern the University of Louisville Hospital was at the request of the State of Kentucky. The resultant organization was the "University Medical Center Inc" (a 501c3 nonprofit, charitable organization). The affiliation agreement to form a management consortium was signed February 6, 1996 (Affiliation agreement, p1). ${ }^{251}$

\section{Getting the University of Louisville Hospital Back into Local Hands}

According to a number of informants, the impetus for this partnership was a shared desire to see Columbia-Hospital Corporation of America (HCA) leave town. Columbia HCA had acquired Humana's hospital subsidiary Galen Healthcare ${ }^{252}$ and assumed the management contract for the University of Louisville Hospital. The management contract with the state of Kentucky had a clause that required Columbia HCA to maintain its home office in Louisville. Columbia-HCA relocated out of

\footnotetext{
${ }^{250}$ One informant specified that it was a governing model and not a management model. It evolved that way in response to University of Louisville Medical School faculty concern that the hospital would be managed by two competitors. Both Norton and Jewish had board members serving as UMC board members.

${ }^{251}$ According to one informant, the board of UMC was organized as such to balance Jewish against Norton but still get the management contract from the state of Kentucky. The board structure of 12 seats included three seats for representatives from Norton and three from Jewish and six from the University of Louisville. The informant said "... very little that goes through that one or the other side doesn't want."

${ }^{252}$ The reader is reminded that Humana is a hometown corporation and that co-founder David A. Jones was viewed as a mover and shaker in healthcare.
} 
Kentucky to Nashville Tennessee in violation of the management contract $^{253}$ providing the opportunity for local cooperation.

The relevant responses of the informants centered on how an agenda could be shared by competitors. One informant said, "There was an environment where each of the two organizations could look beyond their parochial interests to look at a community interest." Another informant observed said that both Jewish and Norton were supporting the University of Louisville School of Medicine, and getting Columbia out of the picture was in their interest. Another informant said that the actors wanted to preserve the University of Louisville Hospital as a teaching hospital, indigent care provider, and trauma center, and they appeared to have the initial pull in the early days of the consortium. Still another informant said there was control over niches,

Therefore the university had very little leverage with its faculty and over the years, the clinical teaching programs have been spread around in the medical center. Norton had psych and Norton had obstetrics, and Norton had orthopedics. Jewish had heart and rehab ... it (university) was a safety net hospital, as the successor to the Louisville General Hospital. But that was one of its roles and as the trauma center and they just didn't do a whole lot of what you would call traditional medicine.

While Jewish and Norton raised the standards of the University Hospital, they

simultaneously maintained the local status quo through the management consortium and maintain their corners of the market.

The management consortium opened a chapter in time where Norton (then Alliant Health System Inc.) and Jewish leadership explored the extent cooperation. Both organizations mulled a merger for two years from 1996 to 1998 when Columbia HCA

${ }^{253}$ One informant said that Columbia-HCA CEO Rick Scott relocated the company from Louisville to Nashville, Tennessee after learning that he would have to pay a Kentucky state intangible tax on his Columbia-HCA stock which would be more than his yearly salary. He moved by the last possible day to avoid paying the tax. The Kentucky intangible tax Scott moved to avoid paying was later ruled illegal. 
had ownership of the three former Humana hospitals outside of Downtown Louisville.

According to some informants the attractions of a merger were the potential efficiencies and the cementing of control in the downtown medical complex. ${ }^{254}$ The aforementioned Wagner (2003) briefly mentioned this attempted merger in his memoir chapter in Passing the Torch. He also noted that he was disappointed that it fell through (p.499). According to the informants who commented, the differences in the Jewish and Norton organizational cultures was the reason Norton backed down and went in a different direction by purchasing the Columbia HCA hospitals. 255256

Despite the failed merger, informants noted that Jewish and Norton continued to cooperate in the consortium as it served their interests. The consortium began to threaten their interests a few years ago.

\section{The Breakdown of the Interlocks-Money and Competition}

The money Norton and Jewish gave to the University of Louisville Hospital was needed to maintain the status quo in the beginning but eventually disrupted it. According to a number of informants, Humana and Columbia in the last years of the respective management contracts were profit-taking and not reinvesting in the University Hospital

\footnotetext{
${ }^{254}$ This was a very sensitive subject that a number of informants declined to discuss.

${ }^{255}$ The informants indicated that Jewish and Norton were very close to signing a memorandum of understanding to merge. Instead, Norton decided to buy the three Columbia-HCA hospitals and was able to keep it secret from Jewish. One informant reported an anecdote indicative of the secrecy that Hank Wagner (then Jewish CEO) heard about the Norton-Columbia deal from the editor of a national medical trade publication while at the 1998 Kentucky Derby and spilled his drink in shock. There were no print stories in the "Louisville Courier-Journal" or "Business First" reporting the intended merger or the failed merger. The only print reference of this failed merger is the cited passage in Passing the Torch. Despite all of the actors, they were able to keep all of the discussions confidential from the general public.

${ }^{256}$ Another theme that does not seem to fit cleanly into this discussion about inter-locks, but may be a matter for future research, was an appearance of traditional alliances. One informant noted that Norton Healthcare and its predecessors historically has had a bond with the Wyatt Tarrant Combs law firm. On the other hand, during the SNA sampling, it was noted that Jewish had no members from Wyatt Tarrant Combs but has drawn board members from the Frost Brown Todd law firm and other law firms. It is possible that the organizational cultures and politics are products of the enduring linkages between the organizations.
} 
infrastructure. ${ }^{257}$ As part of the affiliation agreement both Norton and Jewish guaranteed up to $\$ 35$ million in "capital commitments" the first year of the consortium to rejuvenate the University of Louisville Hospital facility and purchase needed, new equipment (Affiliation Agreement, p.19).

Over the course of the 11 years the consortium gave back over $\$ 100$ million to the University of Louisville Medical School. However, the institution of University Medical Center Inc. also became stronger in and of itself thanks to Jewish and Norton's contributions. $^{258}$

In the meanwhile, the University of Louisville Medical School hired Joel Kaplan as the new dean under contract to pursue an agenda of growth and grow the " $\mathrm{U}$ of $\mathrm{L}$ brand." Kaplan's agenda combined with the ambition of UMC CEO James Taylor made University Hospital into a competitor with Jewish and Norton which created political conflict. $^{259}$

Informants reported that University Hospital began encroaching on Jewish and Norton's corners of the market. There began to be rumblings when investments were made to upgrade the University Hospital obstetrics unit (Obstetrics is a Norton specialty). Also, both Norton and University have cancer centers. ${ }^{260}$ University also developed heart catherization labs, encroaching on Jewish's territory. One informant noted that

\footnotetext{
${ }^{257}$ One informant said that University Hospital's infrastructure was 'terrible" as a result.

${ }^{258}$ The last year Columbia HCA had the contract; it gave $\$ 75,000$ back to the University of Louisville. In the first three years of the consortium, $\$ 25$ million was returned to the University of Louisville.

${ }^{259}$ Informants tended to voice much respect for CEO, James Taylor, for University Medical Center. One informant said that he (Taylor) "had ambition to grow it and it fit the ambition of the University. What happened is that they found that they can grow that hospital. "

${ }^{260}$ Norton unveiled a "cancer initiative" where it will spend $\$ 100$ million over five years on cancer outreach. (Howington, 2007, January 19). This compares to the outreach by the U of L Brown Cancer Center.
} 
University Hospital evolved from being the municipal hospital to having lines of expertise emerging, which were "a competitive threat to those two hospitals."

On the other side the University of Louisville complained that UMC Inc could not do any independent strategic planning ${ }^{261}$ as Jewish and Norton new everything as both competitors and governors. ${ }^{262}$ As previously noted, The University of Louisville had a desire to develop the " $U$ of $L$ brand" in the community in its own right which meant competition with Jewish and Norton. Those complaints combined with the push to grow University Hospital in terms of improvements and additions in specialty services led to increased conflict between the University of Louisville and Norton. As a result the University of Louisville implemented a clause of the affiliation agreement to terminate the affiliation (Affiliation agreement, p.37-38) ${ }^{263}$ This termination of the affiliation was reported in The Courier-Journal (Howington, 2007 July 10).

The conflict continued after the University of Louisville's move to end the affiliation. Two informants confirmed that during the early part of 2007 after the move by the University of Louisville to reorganize and have Norton and Jewish withdraw from membership, the UMC board had lacked a quorum and could not conduct any further business.

The Louisville Medical Development Corporation

Many of the same University Medical Center (UMC) actors also had a part in the Louisville Medical Center Development Corporation (LMCDC). The LMCDC was incorporated in 1997 at the initiative of Jerry Abramson, in his first tenure as mayor of

\footnotetext{
${ }^{261}$ According to Section 4.3 of the Affiliation Agreement UMC was to engage in strategic planning (p6) 262 "Governor" is still the best word to describe the type of relationship Norton and Jewish had with UMC.
} 
pre-merger Louisville. Abramson resumed his role as LMCDC chairman in 2003 when he was elected Mayor of the new consolidated Metropolitan Louisville. Abramson continues to serve as the LMCDC chairman. $^{264}$ The same Jewish, Norton, and University of Louisville governors were on the LMCDC board. All three organizations had been contributing $\$ 187,000$ per year to the LMCDC.

One of LMCDC's initial agendas was improving the aesthetics of signage in the Louisville Medical Center. 'The informants consistently noted that in the late 1990's its focus shifted to real estate and economic development for medical center related activities such as the "Metacyte" research facility and developing the old "Haymarket" into a research park. However, like the UMC, this organization has followed a similar fate as UMC due to what one informant called a "change in environment."

The informants consistently stated that Norton and Jewish have maintained that withdrawing from the $\mathrm{LMCDC}$ was based on mission. ${ }^{265}$ One informant said that the hospital organizations recognized that their missions do not include being in real estate development. The hospitals were not going to benefit from the LMCDC other than as community citizens. Fiscal issues assisted in making decisions based on mission, especially for Jewish in its fiscal strain of recent years and reorganization (Howington, 2006, November 8).

However, the rationale for Jewish and Norton to withdraw from the LMCDC was not entirely economic. The positive political environment engendering cooperation and

\footnotetext{
${ }^{263}$ Given The Courier Journal Story and the responses from informants, it appeared that Section 26.2.2. of the Affiliation Agreement giving the University of Louisville "special termination rights" best described what happened in procedural terms.

${ }^{264}$ David Armstrong, as mayor of Louisville from 1999 to 2003 served as chair of the LMCDC.

${ }^{265}$ This agreed with a story in Business First which was published before the interviews had been conducted (Green, 2007 February 16)
} 
collaboration was changed by the conflict at University Hospital and the University of Louisville's individual development efforts downtown.

One informant said that "the mood to work anything out and to collaborate at the LMCDC was hampered enormously" The attitude of Jewish and Norton became "You're not helping us over here, why should we help you over here?"

Like UMC, the University of Louisville has taken over control of the LMCDC as it has "commercialization of technology" as a major part of its mission. Plus, the University of Louisville has a legislative mandate in the "Post Secondary Improvement Act" of 1997 to improve economic opportunity and quality of life, a mandate that Norton and Jewish do not share. However, unlike UMC, a number of informants independently said before The Courier-Journal reported (Howington, 2007 July 10) that Jewish and Norton executives will both continue to be members of the LMCDC organization as they need to be part of the structure, but will have smaller roles.

The Future of Interlocks in Louisville Healthcare

In light of the detachment among the organizations within the Medical Center, a number of informants questioned whether there was a future in cooperation in Louisville healthcare. However, a number of informants saw cooperation as inevitable.

The actors are connecting in other ways. For example, Jewish and the University of Louisville had cooperated in creating a cardiovascular research institute. One informant said that Norton and the University of Louisville were looking for other ways to cooperate despite the break-up of the governance consortium of UMC. The organizations operating in the downtown Louisville Medical Center are still working together in some form. 
Overall comments about the tension between cooperation and competition

While not all interlocks were of equal value, there is the quandary about how a dual state of cooperation and competition can exist in Louisville healthcare, especially among the interlocks of most significance. Primarily in Louisville, Norton and Jewish are the prime actors who have initiated legal action against each other while cooperating intensely in other ways.

A number of informants said that the situation starts with each institution acting in its own interest. A common theme was the hospital organizations are first competitors and that each institution looks to its own interests first. When it is in its own interest to cooperate, or the community interest does not conflict with its own interest, a hospital organization cooperates. One informant said that all the hospital organizations have a mission to provide care for more and more people. In this context basic market logic appears to determine the political positions. Overall, a theme from most of the informants with an opinion on this was that the different organizations do not want the competitors to have an advantage, and will go to court to maintain parity in the marketplace.

A number of informants offered generalizations. One informant said that this tension is not unique to medicine: "If you looked at the board of the Michigan State Chamber of Commerce, you find Ford executives and General Motors executives" and they are intense competitors. One other thoughtful informant said that the hospital organizations are competing for patients, publicity and grants, but because there so many 
common actors they fit within Adam Smith's original theory that people of the same trade do tend to talk and work together to fix prices. ${ }^{266}$

In summation, within the interlocks in Louisville healthcare, the political tension depends upon the interest of the actors. The actors are both individuals and organizations and not just individuals per se. The stance of all of the organizations is that they are competitors first and they will cooperate if it fits their interest, but will go to necessary extents to compete.

\section{The Unique Case of the "getCare Network"}

As noted in the chapter introduction, one of the questions regarding healthcare politics in Louisville is the "getCare Network." It was a central organization in the SNA results, but it closed down due to funding.

The getCare Network was a local demonstration of the Robert Wood Johnson Foundation's "Communities in Charge" (CIC) initiative and was in operation from 2002 through 2005. The CIC initiative was a redistributive program aimed at providing healthcare services to the under-insured. It had three components: 1) referring the poor and uninsured to healthcare providers, 2) recruiting doctors to take 10 pro-bono patients, and 3) medical case management to see that the poor received continued and coordinated care in order to prevent repeated emergency room visits for non-emergency primary medical care.

The publicized reason for its closure was Hurricane Katrina hitting the Gulf Coast, and taking priority for federal funding that otherwise would have came to Louisville (Hall, 2005, October 25). Given getCare's high centrality and its numerous

\footnotetext{
${ }^{266}$ The actual quote of Adam Smith provided by the informant is ...People of the same trade seldom meet together, even for merriment and diversion, but the conversation ends in a conspiracy against the public, or
} 
elite board members, there are two questions: why did this redistributive effort draw so much elite attention, and why did this close down even with all the elite participation? Not all informants had an opinion about this program, and some had never heard of it. getCare's Attraction

What led to the assembly of so many elites in the getCare organization? A number of informants said that getCare had a compelling program design. One informant said,

Well, they were people who were concerned citizens of the community about the very large number of citizens in this community who weren't getting healthcare. It just naturally fell together. My recollection is that the Robert Wood Johnson encouraged us to get into this thing ... to look at it. They made available substantial support and advice.

Another reason given for the attraction to getCare was the quality of leadership, and that the University of Louisville and the Family Health Centers were both strong leaders in the organization.

$$
\text { getCare's Closure }
$$

If all these elite individuals were involved in this organization to the extent that they were, would getCare not have access to more local resources to sustain it? Two recurring answers were: 1) getCare was actually competing for the same funding as the established programs in Louisville and 2) the existing safety-net providers were already involved in getCare. One informant said,

If there had been a new, separate source of funding, I think it might have had a different result. But when it was a zero-sum game, it wasn't going to get funded unless something got defunded, I think that changed the dynamics a bit. That was oranges in terms of services delivered. And yet, it was coming from the funding for the apples.

in some contrivance to raise prices (Wealth of nations I.x.c.27. p.145) 
According to informants getCare was a reallocation of resources from existing sources, and it taxed community resources.

Two informants pointed out that the localities that have been able to sustain the Communities in Charge program have a local taxing district that finances such effortsotherwise in Louisville, the getCare activities were drawing money from existing programs apart from the federal grant. ${ }^{267}$ Louisville did not pass any ordinances for financing districts for, which gives some suggestion about Louisville's political culture Louisville.

\section{The Lack of Network Connection between the Private and Public Sectors}

The SNA results noted that there lack network connection between public health agencies and the non-profit organizations. As illustrated in figure 2 , the mental health and public health sectors were not part of the network in the UCINET-generated network graph. This finding was reinforced in the Multidimensional Scaling (MDS) results in figures 3 and 4 . Why was this?

The relevant informants were asked about this disengagement. The consistent answer was that the public sector agencies were required by federal law to be representative of the community-to include consumers. This bore some propinquity to the historical findings discussed in chapter IV on the federal regulations Kentucky Health Systems Agency West (KHSAW) was subject to during its existence.

\footnotetext{
${ }^{267}$ This answer was supported by the outcome evaluation posted on the Robert Wood Johnson Foundation website (http:/ www.rwjf.org/reports/npreports/cic.htm. The Robert Wood Johnson web page on the Communities in Charge program said, "A long-term effort will require a funding source such as a taxing district-that cannot be diverted to other needs during budget shortfalls." Frankly, it appears that Louisville is a locality with a political culture that will only allow tax increment financing districts if the money is to go for economic development.
} 


\section{The Closing of Southwest Hospital and Relocation of its Beds}

While the political fight to make Southwest Hospital a reality was discussed in Chapter V, its closing will be discussed here. This section will first discuss the chronology of the changes and then informant comments on the closure and relocation.

\section{Background}

Norton had purchased Southwest Hospital from Columbia HCA in 1998 as part of its larger purchase. Business First initially reported in January 2005 that Norton was reviewing options to make Southwest Hospital "more efficient and profitable" (Norton Healthcare reviewing options for Southwest Hospital 2005 January 20).

Norton made transitional moves during 2005 for the inevitable. In February 2005, Norton announced that it was going to move all the skilled nursing services and most of the surgical services to Audubon Hospital in another part of Louisville. Eighty-four jobs were to be cut and the displaced employees were to be offered positions elsewhere in the Norton organization. Norton officials said that total inpatient, surgical, and skilled nursing volumes were down. (Gordon, 2005 February 17). In December 2005 Norton applied to the state CON office to move Southwest Hospital's beds to Norton's proposed new hospital in the northeast part of the Louisville Metro.

Local community activists did get coverage as early as early as October 2005. The Courier-Journal gave attention to a Louisville Metro Council member's protest that Norton was abandoning the southwest corner of the metro (Howington, 2005 October 1). A coalition of emotional protesters ${ }^{268}$ attempting to exert popular control got a hearing in front of an administrative law judge in Frankfort (the Kentucky State Capital) to 
challenge Norton's application (Howington 2006, February 10). Despite the activists' effort to keep Southwest Hospital open, Norton's request for bed transfer was approved by the state CON office a week later (Howington, 2006 February 18). The community protesters faded from view after February 2006. Furthermore, there was no other reported challenge from other healthcare providers. The local media focused on Norton's development of the new, state of the art Norton Brownsboro Hospital in the northeast corner of the metropolitan area.

Norton ceased operations at the Southwest Hospital site and sold the property to Trilogy Health Services. ${ }^{269}$ The Jewish Hospital-St Marys Healthcare organization ${ }^{270}$ leased the Emergency Room from Trilogy and started performing routine, outpatient diagnostic services that Norton had been providing (Davis, 2007 June 1).

\section{Informant Responses}

From the different responses, the picture pieced together was it was no surprise that Norton moved the beds from the southwest corner of Jefferson County to the northeast corner. Informants consistently said it was only a matter of when Norton was going to do it. The informants generally agreed that the "payer-mix" ${ }^{\text {"271 }}$ of patients is better where the new hospital is being built, and thus it is more economically viable.

\footnotetext{
${ }^{268}$ The story noted that the parties that requested the hearing were the sitting Louisville Metro Council member for that part of the city, a Republican Party candidate for the Kentucky House of Representatives, and the Valley Women's Club.

${ }^{269}$ Trilogy is a low-key proprietary provider of health services. It is based in Louisville but has most of its assets outside of Louisville. They converted the top floors of the facility into a nursing home facility. ${ }_{270}$ JHSMH was the result of the merger Caritas Health Services and Jewish Hospital Health Services in 2005. This Jewish-Catholic marriage of sorts was explored in other interview questions, but was of little political significance. This merger was by far of more economic significance as per informants as Caritas needed capital investment and was too small in and of itself to continue to survive in the local market. The merger was actually made by Caritas' parent organization Catholic Health Initiative based in Denver Colorado and Jewish.

271 The term "payer-mix" was used by some informants and was not an original focus of this study and refers to types of reimbursement a facility will receive for serving different socioeconomic groups. .
} 
Also, a number of informants saw that it was difficult for Norton to attract specialists to practice at Southwest Hospital.

Some informants said that Norton had every right under state law to move the hospital, and there was actually nothing political about it. The CON law in Kentucky allowed for the moving of all the beds (not more - not less) within the same county without requiring CON office approval- - only notice. Two informants recognized that while the state legislator and metro council member were offended in the southwest corner of Louisville to lose a hospital, a state legislator and metro council member were happy in the northeast corner of Louisville to have a new hospital.

Some informants said that Norton officials did talk informally among the relevant parties about the planned move. The Metro Government officials took no action. One informant said that the communication involved a quid pro quo where Baptist and Norton and Jewish were all in agreement about the need for growth. According to the informant, Norton and Jewish agreed not to challenge Baptist's new large addition, Norton and Baptist agreed not to challenge Jewish's application for 75 new beds, and Baptist and Jewish agreed not to challenge Norton's closing Southwest and moving the beds.

The lesson of Norton's closing a hospital and moving the fungible beds was itself a matter of elite political-economic exercise. The attempt by lower echelon politicians was made too late in the process and was ineffectual overall. The move was more out of economic logic than political logic, and that the elite players had made an agreement to allow it. It was an apparent deal where in the end all the hospital organizations as players were able to get some benefit out of it to advance growth agendas. 


\section{Conclusion}

This chapter argued that there was support for the growth machine thesis as an explanation for local healthcare politics from elite interviewing results. Informant responses consistently identified that is the primary agenda of the political actors. The informants uniformly reported that there was currently no one opinion leader but there is a group of organizations and their executives who are the movers and shakers in Louisville healthcare politics. Furthermore, these parties keep the political decisions among themselves.

With regard to the SNA results, the interviews provided support for the elite interlocks having some meaning, but not all the interlocks were equal in significance. The informants did not see the most central GLI organization as a central or powerful actor in healthcare. GLI turns out to be more or less a place where the influential in the community meet-including the leading players in healthcare in Louisville. The most significant interlocks as per the informants were downtown in the Louisville Medical Center through UMC and LMCDC. At the time of the interviews, the Baptist Healthcare Organization was considered an outsider. The interlocks developed when two competitors came together as a way to get rid of a third competitor and to preserve and enhance their interests as teaching hospitals for the University of Louisville School of Medicine.

The combination of the Medical Center interlocks, the dual state of cooperation versus competition, and the eventual disintegration of the interlocks must be understood in terms of basic market logic. All of the primary organizational actors have agendas to 
grow their market share meaning that they are in competition with each other but will engage in collaborative efforts when it is in their interests.

Norton, Jewish, and University Hospital had benefited from the UMC management consortium of University Hospital for a time. Jewish and Norton got Columbia HCA out of the Medical Center and developed an advantageous status quo while University Hospital's infrastructure received needed improvement.

However the political status quo of University Hospital being dependent on Jewish and Norton was not going to be sustained in perpetuity. The University of Louisville acquired other resources and leaned on its state-mandated mission of economic growth to compete with Norton and Jewish. The interests of Jewish and Norton were no longer being served in UMC. They also clarified their interests, which meant detaching from LCMDC. In the end it appears that the economic and political reasons for the interlocks no longer existed and they were discontinued or rearranged.

Several other questions were explored to understand the extent of actor participation and agendas. These will be summarized in the next several paragraphs.

Informants report that the Mayor of Louisville and Louisville Metro Government are passive players who are more involved in economic development activities except for the QCCT to pay for indigent care at the University of Louisville. The Mayor's reputation is that he is interested and informed and serves as a cheerleader for development. The mayor strongly supports the Louisville Metro Department of Health and Wellness efforts to reduce health disparities in Louisville. Nevertheless, in political terms healthcare is first a major industry in Louisville that contributes to the tax base and 
holds great potential for further economic development and both the Mayor and the Metro Government have interests in those aspects.

There were several other phenomena that were explored to see where they fit in to healthcare politics. These phenomena were: getCare, and the closing of Norton Southwest Hospital.

The "getCare" Network was a unique occurrence as an organization with a redistributive purpose that had a high Bonacich eigenvalue in the SNA results. It had much elite support and participation but closed down when federal funding could not be renewed.

Norton Healthcare's moving the license for a whole 127 bed hospital as a local political matter was indicative that the elite in general approved resources to be moved from a relatively stagnant area of the metropolitan area to a growing affluent area. Using economic logic, the elite decided the matter among themselves without involving the general public. The attempt by lower echelon politicians to challenge the move was small and short-lived. In the end, Norton had the prerogative to move the beds and had strong economic logic for doing so, but engaged in what appeared to be the necessary political activity as was fitting for the political culture of Louisville.

The lack of local political connection between public health organization (both generic public health and mental health) and the rest of the network was very dramatic. The SNA results demonstrated clear graphical results to this effect. The public sector and private sector providers are isolated for the most part due to strict federal regulations. Relevant informants repeated that federal regulations require diverse membership that is representative of the community, and that essentially negates the involvement of locally 
connected elites on public health and community mental health boards of directors. This type of regulation is explored further in the next chapter.

However, in coming back to the local aspect of healthcare politics in Louisville, economic growth and market logic were prevalent themes in the informant responses as to what drove politics-similar as to what Lennarson-Greer noted in her seminal article. Economic development and market competition were at the heart of the criteria and motivations of local political decision-making. The elite actors in healthcare politics appear to be adept at maintaining decision-making power at their levels. Furthermore, the Louisville hospital organizations now have political power as large employers with the ability to assert and maintain their political stances within the community to their competitive advantages. 


\section{CHAPTER VIII CONCLUSIONS AND RECOMMENDATIONS \\ Overview}

This chapter is a summation of the intent of this work, a summation of the results and some of the specific lessons arising from the exploration. It ends with recommendations for future research.

\section{The Intent of this Work}

This dissertation advanced knowledge and filled a gap in understanding the local aspect of healthcare politics in terms of urban governance theory. There were significant questions about the identities of the political actors, their agendas, and how they act.

This dissertation reported the results of a disciplined-configurative case study that tested whether the growth machine thesis can explain the power structure and activity of local healthcare politics in Louisville, Kentucky. The growth machine thesis is a politicaleconomic theory conceived by Molotch (1976) describing political structure and activity at the local level. Molotch theorized that locally dependent elites as a growth coalition united for the purpose of growth make the political decisions for a local area. Logan and Molotch (1987) identified the categories of livelihoods that compose the growth coalition.

This dissertation was a case study that had two main research questions: 1) is there a growth machine in Louisville, and 2) does it shape local healthcare policy. The 
case study design to test the questions consisted of a historical analysis of past healthcare politics in Louisville, a social network analysis (SNA), and interviews with informants identified as being central in the SNA results.

The Answers

Is there a Growth Machine in Louisville?

The essential answer to the question of whether there is a growth machine in Louisville is yes. This study by historical, empirical and qualitative analyses affirms the previous studies (Whitt, 1989, Savitch and Vogel, 2004, and Savitch, Tsukamoto and Vogel, 2008) that there is a growth machine in Louisville. This study adds that a growth machine apparatus has existed in Louisville for a long time.

The growth machine has shaped various aspects of the Louisville. Whitt identified that the growth machine apparatus shaped Louisville's focus on the arts. Savitch and Vogel identified that the growth machine drove the city-county consolidation in 2000. Savitch, Tsukamoto and Vogel identified that the mayor and Greater Louisville Inc together form a growth machine in the way they deal with political and economic realities (p.453). The question that follows is whether it shapes local healthcare policy in Louisville?

Does it Shape Local Healthcare Policy?

It is argued that the growth machine apparatus in Louisville has shaped and continues to shape the limited local healthcare policy that it is allowed to shape within the structure imposed by the higher state and federal levels of government. From the results of this study the conclusion is that if any local healthcare policy can be locally shaped 
and driven by local healthcare politics, it is growth and development driven by the growth machine.

Historical Review

Historically, the growth machine apparatus initiated the idea for the Louisville Medical Center in the mid 1940's and was the driver of its development. The idea for the Medical Center started in the Louisville Area Development Association (LADA) and not city hall. The list of the parties driving the development was dominated by individuals and institutions from Logan and Molotch's list of locally dependent livelihoods and institutions comprising the growth coalition. They were able to monopolize decisionmaking privately among themselves and keep the general populace out of it.

The growth coalition then invited government in when government had resources or capabilities the growth machine needed to further the growth agenda. The growth machine seemed to have little problem motivating the city of Louisville and Jefferson County to go along with the plan. The growth machine apparatus also had the ability to persuade the State of Kentucky to assist in coaxing the Methodists and Evangelicals to build their hospital in the Medical Center where the growth machine wanted it. The growth machine's influence fell short in its failure to change the Federal Government's mind to build the V.A. Hospital in the Medical Center versus in a northeastern part of the city. There were limits to what the growth machine apparatus could do in the past.

The growth machine started the local Louisville Area Health Facilities Council (LHFC) in 1966 in the name of growth. The LFHC was a local health planning agency organized under the auspices of the Louisville Area Chamber of Commerce (the LADA successor) and not city hall for the intent of local growth within the city. The roster of 
the LFHC board members again was dominated by Logan and Molotch's list of political figures from growth coalition livelihoods.

Through the historical trajectory of the local health planning agency it is observed that the Federal Government's imposed agenda for local health planning was different from the Louisville growth machine agenda. Between 1968 and 1976 the Federal Government added intergovernmental support that imposed more and more rules or structure that weakened the growth machine's dominance and power to carry out its development agenda. As was reviewed in Chapter V the Federal Government's increasing number of matching-funding rules caused local crisis, chaos and confusion for the local stakeholders engaged in local health planning. The crisis and confusion amidst the chaos almost led to the local agency's demise. The weakened state of the growth machine in this case allowed some non-elites with a different growth agenda to gain a bargaining position at the table. At the end of the trajectory, the Federal Government shut out the growth machine and the local health-planning agency looked very different with average consumers in the leadership positions. As a further contrast, the non-elites did not get to act in pluralistic fashion, but were constrained to conduct local health planning in bureaucratic fashion. The historical review showed that the growth machine could only use local healthcare planning as a development tool as tolerated by the Federal Government.

\section{Review of the Recent State of Affairs}

Does the growth machine continue to shape local healthcare policy? The question was answered in two steps. 
The first step was the social network analysis. The results support the conclusion that the growth machine apparatus is central and thus in power in Louisville healthcare politics. The growth coalition livelihoods as entities are central in the community and closely tied to the hospital organizations but not public health agencies. Individuals from growth coalition livelihoods were central in the overall network and dominated the two most central cliques in the network results.

The second step of elite interviewing affirmed an agenda of growth when it comes to local healthcare politics. The informants confirmed that local healthcare political activity is about growth. The foci of local healthcare politics in Louisville have been:

- land use,

- growth of the local, non-profit hospital organizations, and

- the continued development of medical research through the University of Louisville.

The answer from the research results of the current state is therefore yes ... the growth machine shapes local healthcare policy.

\section{Lessons from the Research}

Several lessons arise from this research. This section will discuss those lessons. Federal Policy Detaches Public Health Agencies from Local Healthcare Politics

Federal policy has created and maintained a distance between the local political structure and local public health agencies. The historical trajectory of local healthcare planning between 1966 and 1982 demonstrates how the federal government forced the growth machine away local health planning and replaced them with the non-elite consumers. The social network analysis clearly demonstrates that the local public health 
and mental health agencies have little connection with the growth machine and local business interests. Informants in the field interviews confirmed that federal policy dictates that membership of those boards must come from consumers who are representative of the community. ${ }^{272}$

In Local Political Terms, Healthcare is More a Developmental than Redistributive Good.

Despite the ideal that everyone should have access to healthcare, the concern of healthcare politics in Louisville has been how much development can be derived from healthcare. While the main Louisville hospital organizations are non-profit and do provide indigent care, they have proven to be avenues of economic growth and development. Local politicians want hospital organizations to thrive and contribute to the local economy and tax base. Furthermore, hospitals generate economic externalities such as work for attorneys, development of allied healthcare sectors, and improved infrastructure initiatives that employ building trades.

Through the harnessing of the University of Louisville Medical School research agenda healthcare also is growth machine tool of a high tech growth pole. The Louisville growth machine created the Louisville Medical Center and has continued to enhance it to enable the city to compete in the global economy.

\section{The Growth Machine Thesis may be Refined}

The results of the research suggest that the growth machine can be refined in two ways. First, the list of growth coalition livelihoods and organizations could be expanded

\footnotetext{
272 An interesting research question arising out of this lesson is exploration of the level of pluralism that drives those agencies since the board members come from the community. It light of the KHSAW organization, irony is expected that those organizations as a whole are driven by federal policy since they depend on federal funds for reimbursement for services.
} 
based on the criteria of local dependence. Second, there might be variants of growth coalitions depending on the local arrangement of industry and institutions.

\section{Hospitals are Growth Coalition Members}

In Louisville, the local hospital organizations are locally-dependent upon revenues they generate from services rendered mostly to local patients. Regardless of how hospital organizations are paid, they collect the revenue by mostly serving local patients and increasing the number of patients served.

As a local organization the fortune of the hospital is tied to the fortunes of the local economy. The hospital is even more tied to the fortune of the immediate neighborhood surrounding the hospital. As a matter of political and economic tension if the local political figures expect hospitals to be a sustainable source economic growth, hospitals will need to be assisted in creating conditions that will first sustain and then empower them by all possible local means to continue to grow and development so as to continue contributing to the tax base. ${ }^{273}$

Local healthcare executives in Louisville are already active in the growth machine. Hospital organization executives especially are involved in GLI and community leadership roles.

\section{Doctors could be in the Growth Coalition}

The physicians in Louisville are not an active group in the growth machine. Informants identified physicians as being interested in developing the services of the

\footnotetext{
${ }^{273}$ The Methodist Evangelical Hospital history taught this problem. The MEH founders wanted it in the East End of Louisville where it would have an advantageous location for growth. The Growth Machine wanted it downtown and that was where it went. It closed down because it did not grow into a teaching and research hospital of the University of Louisville with tertiary services, but had remained a general, community hospital that lost its community (Amster and Zingman, p.85).
} 
hospitals and interested in maximizing their own revenues, but they are not involved in the political aspects at the larger community level.

As individuals, healthcare executives, physicians and other licensed independent healthcare practitioners could very well be included in the growth coalition. They are all locally dependent--they get their revenues from patients primarily living in the local area. Their revenues depend upon the economic health of the local area and they have unknowingly depended on the growth machine to shape the city and its infrastructure that enables them to continue in their livelihoods.

However, physicians have an indirect relationship with the growth machine apparatus as hospitals are dependent upon physicians to admit patients to make revenue. Hospital organizations improve their facilities and equipment to improve physician satisfaction, which in turn will mean more hospital revenue.

Hospital organizations also attract physicians by locating in advantageous locations and constructing medical office buildings adjacent to hospital facilities. In Louisville these spatial arrangements exist around all the hospitals but especially in the Louisville Medical Center, and the St. Matthews area around Norton Suburban and Baptist Hospital East. ${ }^{274}$

\section{Suggestions for Future Research}

There are several possibilities for future study. This section discusses research questions that arise out of this study. .

\footnotetext{
${ }^{274}$ Looking at these areas also indicates that these building arrangements are aesthetically pleasing or awe inspiring which further enhances the local environment.
} 
1) Explore the second half of urban health politics as defined by Lennarson-Greer.

This study did not explore how cities deal with the "hazards and dangers of urban life and the uneven concentration of disease" as included in Lennarson-Greer's definition of urban health politics. This study explored how Louisville defines and fulfills healthcare responsibilities. Now that it has been identified that the growth machine thesis is a reasonable explanation, a starting point exists for looking at local political approaches to resolve health inequities.

2) Explore this Theory in other Metropolitan Areas Wholly Contained within States The Louisville metropolitan area is a complicated region for urban and economic research because it is on a state line and includes at least five Indiana counties in the area of dominant influence. The large snowball sample for the social network analysis was intended to transcend the geopolitical border and encompass the sociological limits of this metropolitan area. However, a state border implies that there is the potential of numerous regional governance nuances on both sides of the border creating the preponderance of multiple threats to validity. ${ }^{275}$ Repeating this study design in a metropolitan area wholly contained in the same state would best control for these threats.

3) Explore Local Healthcare Politics in Cities in States without CON Limits

At the time of this study, Kentucky continues to have a certificate of need (CON) law. This law assumes that over-building raises healthcare costs and thus regulates the market. Under a CON law, hospitals in an area must all be at a sustained high occupancy

\footnotetext{
${ }^{275}$ Despite the lack of Certificate of Need law in Indiana both Floyd and Clark Counties had a moratorium on new hospital construction until a judge struck the moratoriums down. Jewish Hospital has a management contract to run Clark County Hospital. Former Jewish Hospital CEO Hank Wagner went on the local Fox TV network affiliate's newscast on January 21, 2004 and gave a "point of view" arguing against the construction of a proprietary specialty heart hospital to be built in Clark County. Wagner argued that the proposed hospital would not benefit the community and that it would not support medical research and training (http://wdrbimg.dayport.com/htm/Archive/guesteditorialhealthchallenge.htm).
} 
rate before a state will consider new bed construction. On the Kentucky side of the Louisville MSA the CON law means that the healthcare providers have an imposed scarcity of hospital beds from which to compete and maximize revenue. In Indiana there is no CON law in place. Indianapolis seems to be suitable case since it is wholly contained within the state of Indiana, has a consolidated metropolitan government like, Louisville and its healthcare development is not subject to a CON law.

4) Explore Healthcare Politics as it relates to Market Conditions A number of informants suggested that the Boyle Report ${ }^{276}$ of 1996 was a starting point for the current movement in Louisville to use the healthcare sector for economic growth. The Boyle Report suggested that Louisville was not attractive to most "high growth" industries (p. ii). In light of this reality, the report suggested that Louisville as a city should develop a few technological niches and make itself attractive to business (p.iv). The Boyle Report implied that Louisville has assumed an unfavorable bargaining position.

The term "bargaining position" gets meaning from Savitch and Kantor's (2002) urban development model. In Savitch and Kantor's model, there is a dichotomy between an "advantageous bargaining position" and a "disadvantaged bargaining position." The former position means that the city takes a "social-centered" approach to development and tends to make successful demands upon business and pursue policies that exact business contributions for the privilege of being able to develop in that locality. ${ }^{277}$ The

\footnotetext{
${ }^{276}$ As noted earlier its formal title was "Economic development strategy for the Greater Louisville Region."

${ }^{277}$ At this time in U.S history, people tend to look at Portland, Oregon as probably the closest to this ideal.
} 
latter is a "market-centered" position where cities focus on inducements to attract business (pp.46-47). ${ }^{278}$

While Savitch and Kantor's model is more international in comparison ${ }^{279}$ there are cities in the United States that have different development strategies which may broaden the nuances of understanding healthcare politics in terms of Logan's (1978) concept of "stratification." For example San Francisco and Boston are very different cities development-wise than Houston and Atlanta. Different cities do not always seek the same kind of economic development because they already have preferable industries and economic sectors. The cities with the favorable businesses have the leeway to set limits on what kind of economic development occurs within its location. ${ }^{280}$ The question that arises is: What kinds differences exist in the local healthcare politics of these cities with their differing bargaining positions and market conditions?

5) Explore how Urban Health Politics Relate to Differences in Political Culture. ${ }^{281}$ This is in propinquity to the bargaining positions are the political cultures of the cities. In Savitch and Kantor's model, the local political culture "refers to the norms and values that create a disposition toward the development agenda" (p.45). The two basic cultures in Savitch and Kantor's model are the "materialist" culture that is focused on employment, income and easily divided benefits versus the "post-materialist" culture focused on indivisible benefits and preservation of the historical and natural environments (p.45).

\footnotetext{
${ }^{278}$ Savitch and Kantor write it should not be confused with a lack of competitiveness or an unwillingness to be competitive (p.47).

${ }^{279}$ The Savitch and Kantor model applied to cities in France, the United Kingdom, Italy and Canada in addition to the United States.

${ }^{280}$ Logan (1978) saw this as a class and status issue and that some places have greater ability to choose what kind of development they will pursue.
} 
In Savitch and Kantor's framework, Louisville would best be characterized as having a materialist culture with its emphasis on job development and being attractive to draw in business. So, comparative research in this case would look to a city that is focused on different emphases through a post-materialist culture.

A side note to this issue of political culture may very well have implications for the Robert Wood Johnson Foundation's "Communities In Charge" (CIC) initiative from which the getCare organization was spawned. As noted in Chapter VII, the CIC initiatives that were sustained had been financed by a local tax levied exclusively for indigent healthcare that is not fungible (http://www.rwjf.org/reports/npreports/cic.htm). ${ }^{282}$

It is unlikely that Louisville will pass a tax levy or payroll tax for the purpose of paying for indigent care due to its materialist culture. ${ }^{283}$ However the crux of such research would be to identify the political culture differences between Louisville and venues like Travis County Texas (Austin MSA) and Alameda County California. Travis County has a healthcare "financing district" while Alameda County supports its public hospital and its outpatient clinics through a sales tax (http://www.rwjf.org/reports/npreports/cic.htm). The value of this research would indicate political conditions that can be generated or facilitated to create taxing districts

\footnotetext{
${ }^{281}$ As mentioned in the introduction, it is felt that studying formal urban government structure (Council versus Commission) is irrelevant when looking at future possibilities for comparative research.

${ }^{282}$ The venues that conducted CIC demonstrations would be an interesting purposive sample of localities for such a study.

${ }^{283}$ Louisville-Jefferson County voters also rejected a 2007 referendum to create a library district that would have been funded by an additional payroll tax. The Growth Coalition created an aesthetically pleasing Libraries Yes! campaign with several TV commercials of local elites and public figures encouraging passage. Mayor Abramson touted on radio how the new tax would improve human capital and make Louisville more competitive in the international marketplace through new library construction in the west and east ends, and name-dropped GLI's blessing on the new tax. The Louisville Courier-Journal pitched passage through numerous editorials and guest editorials entitled What the Library Means to Me. The campaign likely failed due to few divisible benefits to the whole consolidated city and the opposition's ability to emphasize ulterior motives of city officials to use the would-be freed-up funds to solve budget
} 
or sales taxes to finance such indigent care and perhaps on how to get to that point in a materialist culture.

6) Explore International Differences such as in Canada and other Countries where Financing is National but Facilities are still under Local Control.

The growth machine thesis has international relevance in the United Kingdom, the European Union and Israel despite contextual difficulties. An opportunity exists to compare how local healthcare politics plays out given the different socialized or nationalized systems. The ability to generalize as much about local healthcare politics may be of value to multi-national medical organizations such as the World Health Organization to identify strategies that can transcend national borders.

Furthermore, local areas that are increasing in local dependence due to national government changes will need to take more responsibility for public infrastructure. How those localities interact with national governments to obtain healthcare facilities and needed healthcare infrastructure poses an interesting question. To be able to generalize political conditions would engender maximization of resource utilization. ${ }^{284}$

With deference to Plano (1999) Toronto would be an initial, interesting and appropriate city in which to start to duplicate this research design for international comparison purposes. Plano had studied local hospital politics in Toronto and Milwaukee, and indicated local control of hospitals in Toronto. ${ }^{285}$ Savitch and Kantor have given an elegant discussion of Toronto governance with a favorable bargaining

short-falls. The opposition replayed a sound-bite from Abramson's 2006 re-election campaign TV commercial that promised his budget would fund new libraries without an increase in taxes.

${ }^{284}$ Tulchinsky and Varavikova's (2000) volume was indicative of this apparent attempt to write for as large of an audience as possible. They seemed to describe as many universal principles.

${ }_{285}$ As was noted earlier, Plano was vague in identifying the actors. However, Plano at least showed that there were local healthcare actors in Toronto. 
position, social-centered economic development policy and strong popular control (pp.172-174). While Louisville and Toronto are more apples than oranges in this case, there may be more similarities given that both localities have undergone metropolitan consolidation and have notable medical schools.

7) Explore Possible Variants in the Growth Machine Apparatus

A different type of question for further research is whether there may be a variety of growth machine apparatus. Savitch, Tsukamoto, and Vogel (2004) noted that the Mayor of Louisville and GLI formed a growth machine. However while GLI was the most central organization in the network analysis, informants said that GLI was not involved in local healthcare issues. Applying social network analysis in terms of the growth machine sectors found that the livelihood of the legal profession in Louisville was far more central in a collective sense than GLI was as an institution, which offered a resolution of that quandary - the growth machine apparatus is still overall central and in control.

However, three secondary questions arise.

- Was this reality a reflection that the local growth machine has certain preferences for growth expression?

- Are there are different growth machines within Louisville?

- Is there a variance in growth machines just as there is a variance in the types of regimes?

A suggestion by Whitt (1989) that is helpful here is that the politics of growth and structure of local networks will vary due to local differences. The reasons for the 
variance include the nature of the local economy, social and economic differentiation, and the local preference of communication (business or social contacts) (p.105).

Assuming the growth machine thesis is generalizable, SNA can be applied to other communities as a whole in a similar fashion to study whether different livelihoods dominate other growth machines. Different research designs could assist in assembling far more sophisticated datasets for a software package such as UCINET that can produce nuances. One specific survey suggestion would be to ask questions about community influence to produce directed network ${ }^{286}$ results of whole cities.

\section{Important Considerations in Duplicating this Research}

Wherever the comparative research is conducted, such a research design will only be duplicated if there is a sufficient amount of information to cover the sociological community as a whole for the social network analysis. This will mean acquiring names of officers and board members of local non-profit/non-government organizations (NGO's), local associations, local government officials, local businesses and local corporations. If the bulk of the main business and political actors of the community is included in the snowball sample, then it is adequately representative in terms of validity.

Standardization of data will be a consistent problem should this research be duplicated. This particular study benefited from the publicly available online databases that were available locally and had a fair degree of standardization. A foreseen problem in duplicating this type of research is that not all localities have the same extent of record keeping of local organizations. The more archaic the record keeping of a city, region or

\footnotetext{
${ }^{286}$ For Scott (1991) A directed network uses arrows to indicate the attitudes in relationships between actors (p.13). A directed network could inform who is sought for advice or direction or information.
} 
national government, the more information will need to be collected through face-to-face transactions which will mean

- the increased investment of time and resources

- extra steps in data cleaning and encoding

- more reliance on ethnographic research.

But given the generalized nature of the growth machine thesis, which points to particular sectors being in political power, ${ }^{287}$ there should be much slack or leeway in any future exploration of this phenomenon.

\footnotetext{
${ }^{287}$ Future snowball samples would include the officers and board members from local organizations identified as members of the growth coalition in the growth machine thesis. Different communities have different growth coalitions due to different compositions and alliances of institutions arising out of locational and historical factors unique to each locality.
} 


\section{REFERENCES}

2 family healthcare proposals approved. (1972, May 10). The Louisville Courier-Journal, p.B4.

$2^{\mathrm{d}}$ unit buy planned site of hospital: Crippled-child society gets Broadway tract (1956, September 18), The Louisville Courier Journal, section 1, p.1.

A chance to reconsider the site of the churches' hospital (1953, September 28), The Louisville Times, section $1, \mathrm{p} 4$.

Adam, S. \& Kriesi, H. (2007). The network approach. In P.A. Sabatier (ed). Theories of the policy process (129-154). Boulder, CO: Westview Press.

Adams, C. (2003) The meds and eds in urban economic development. Journal of Urban Affairs, 25:571-588.

Adkins, S. (1954, September 12). Delay on hospital blamed on politics, The Louisville Courier -Journal, section 1, p.1.

Alford, R.R. (1975). Health care politics. Chicago: The University of Chicago Press.

Allain, G (1999). The state and regional development organizations in New Brunswick Canada (1960-1990): A social control perspective. (Doctoral dissertation, University of California, Santa Barbara, 1999). Digital Dissertation number AAT 9953895. ProQuest document ID: 730582431.

Allen, R. (1988). Business influence on school board and city politics: A test of Molotch's "growth machine" and Clarks decentralization theories using the NORC/Clark 51 cities data. (Doctoral dissertation, The Claremont Graduate University, 1988). Digital Dissertations number AAT 8811908, ProQuest document ID: 7540429591.

Aminzade, R. (1992). Historical sociology and time. Sociological Methods \& Research, 20: 456-480.

Amster, B.L \& Zingman, B.G. (1994). The mission: The history of Methodist Evangelical Hospital 1960-1993. Louisville, KY: Methodist Evangelical Hospital Foundation, Inc. 
Anderson, J.E. (2000) Public policymaking ( $4^{\text {th }}$ ed). Boston: Houghton Mifflin Company.

Area health council applies for federal funds. (1969, February 6). The Louisville Courier -Journal, p.A36.

Area health planning hangs in the balance (1971, April 18). The Louisville Courier -Journal, p.E2.

Axford, N. \& Pinch, S. (1994). Growth coalitions and local economic development strategy in southern England: A case study of the Hampshire Development Association. Political Geography, 13:344-360.

Babbie, E. (2001). The practice of social research ( $9^{\text {th }}$ ed.). Belmont, CA: Wadsworth -Thomson Learning.

Bachrach, P \& Baratz, M.S. (1962). Two faces of power. The American political science review, 56: 947-952. Downloaded from the J-STOR database on June 15, 2008.

Bae, Y. \& Sellers, J.M. (2007). Globalization, the Developmental State and the Politics of Urban Growth in Korea: A Multilevel Analysis. International Journal of Urban and Regional Research, 31:543-560.

Baglioni, M. \& Vicari, S. (1995). Two models of local development politics. Environment and Planning C, 13: 179-194.

Bassett, K and Harloe, M. (1990). Swindon: The rise and decline of a growth coalition. In M. Harloe, C. Pickvance \& J. Ury (Eds.), Place, Policy and Politics: Do localities matter? (pp.42-61) London: Unwin Hyman.

Bazzoli, G.J, Gerland, A. \& May, J. (2006). Trends: Construction activity in U.S. hospitals. Health Affairs, 25: 783-791. Downloaded from the Ebsco Academic Search Premier Database on October 30, 2006.

Belknap, I, \& Steinle, J.G. (1963). The community and its hospitals: A comparative analysis. Syracuse, NY: Syracuse University Press.

Bingham, R.D. (2003) Economic development policies. In J.P. Pelissero (Ed.) Cities, politics, and policy: A comparative analysis (pp.237-253). Washington D.C.: CQ Press.

Blankeship, L.V. \& Elling R.H. (1962). Organizational support and community power structure: The hospital. Journal of Health and Human Behavior, 3:257-269. Downloaded from the J-STOR Database on June 9, 2006. 
Blankeship, L.V.\& Elling R.H.(1971) Effects of community power on hospital organization. In M.F. Arnold, L.V. Blankenship \& J.M. Hess (Eds.) Administering health systems: Issues and perspectives. Chicago: Aldine Atherton.

Board of 35 directors named. (1970, January 9). The Louisville Courier-Journal, p.B1.

Bodenheimer T.S. \& Grumbach, K (2005). Understanding health policy: A clinical approach (4ed) New York: Lange Medical Books/McGraw-Hill.

Borgatti, S. (1997) Multidimensional scaling. Retrieved September 8, 2007 from http://www.analytictech.com/borgatti/mds.htm.

Borgatti, S.P., Everett, M.G. and Freeman, L.C. (2002). Ucinet for Windows: Software for social network analysis. Harvard, MA: Analytic Technologies.

Box, R. (1990). The economic model of administrative behavior in local government. (Doctoral dissertation, University of Southern California, 1990). Digital dissertations AAT0568743. ProQuest document ID: 74071291.

Boyd, R.E. (2005). Gated-community emergence in the metro east: Residential growth and development in St. Clair County, Illinois. (Doctoral dissertation, St. Louis University, 2005).

Boyle, M. R. (1996) Economic development strategy for the Greater Louisville region: Prepared for the Louisville Chamber of Commerce and Greater Louisville Economic Development Partnership. Vail, CO: Growth Strategies Organization.

Bradley, F.R. \& Raper, R.E. (1945) Preliminary Louisville area hospital survey made for Louisville Area Development Association. St. Louis: Author. Presidents Office Files 1929-1971. University Archives and Records Center, University of Louisville.

Brass, D.J. \& Burkhardt, M.E. (1992). Networks and organizations: structure, form and action. Boston, MA: Harvard Business School Press.

Brauttigam D., Rakner, L. \& Taylor, S. (2002). Business associations and growth coalitions in Sub-Saharan Africa. Journal of Modern African Studies, 40: 519 -547 .

Britton and Octavio (2007). Urban and spatial organization: Hospital and orphanage location in Chicago, 1848-1916. Social Forces, 85: 1303-1317.

Broadbent, J. (1989). Strategies and structural contradictions: Growth coalition politics in Japan. American Sociological Review, 54:707-721. 
Bulleit, P. (1966, July 29). Area health advisory moving closer to reality. The Louisville Courier-Journal, p.B1.

Bulleit, P. (1966, December 10). Health advisory panel set for action.. The Louisville Courier-Journal, p. B1.

Bulleit, P. (1968, January 7). New chief of health unit finds job frustrating. The Louisville Courier-Journal, p.B.1.

Bulleit, P. (1968, December 11). Planner is loaned to health facilities council. The Louisville Courier-Journal, p.A.9.

Bulleit, P. (1968, December 31). Group almost off the ground? Health unit names leader attorney Robert Sloss. The Louisville Courier-Journal, p.B18.

Bulleit, P. (1969, January 22). Health planners hear hospital fund appeals. The Louisville Courier-Journal, p.A1.

Bulleit, P. (1969, January 23). Health planning unit meets dissent from Hoosiers. The Louisville Courier-Journal, p.B1.

Bulleit, P. (1969, January 31). 9-county health planning unit outlines organizational plans, budget request.. The Louisville Courier-Journal, p.B3.

Bulleit, P. (1969, August 8). By health facilities council ... hospital occupancy rate due study. The Louisville Courier-Journal, p.A1.

Bulleit, P. (1969, October 1). Falls Region Health Council came into being. The Louisville Courier-Journal, p.A8

Bulleit, P. (1970, March 25). Council wants U of L control, phased building of General. The Louisville Courier-Journal, p.B1.

Bulleit, P. (1970, August 14). New facilities unnecessary? Hospital bed restrictions threaten plans for 2 St. Matthews projects. The Louisville Courier-Journal, p.A1.

Bulleit, P. (1970, September 1). Plans for two St. Matthews hospitals approved by region health council. The Louisville Courier-Journal, p.A1.

Bulleit, P. (1970, November 25). Council rejects plan for Baptist Hospital. The Louisville Courier-Journal, p.A10.

Bulleit, P. (1971, February 3). Health council forced to trim Hoosier ties. The Louisville Courier-Journal, p.A12. 
Bulleit, P. (1972, February 16). 4 new board members to be named . . Falls Region Health Council plans wide 'consumer' representation. The Louisville Courier -Journal, p. 1.

Bulleit, P. (1972, February 18). Approves Methodist hospital addition ... Health council names 7 members. The Louisville Courier-Journal, p. B1.

Burt, R.S. (2005) Brokerage and closure: An introduction to social capital. Oxford: Oxford University Press.

Byck asks V. A. to delay hospital till bond vote: Says counsel wants to give voters a chance to pass on plan to donate a downtown site (1949, January 22), The Louisville Courier-Journal, section 1, p.1.

Calavita, N. (1992). Growth machines and ballot box planning: The San Diego case. Journal of Urban Affairs, 14:1-24.

Card, B.J. (1987). Why cities grow: Elites perceptions in six Texas Cities. (Doctoral dissertation, The University of Texas at Arlington, 1987). Digital Dissertations number AAT 8729907. ProQuest document ID: 751896041.

City to help on Broadway hospital site. (1956, September 5), The Louisville Times, section 1,p.1

Clark, C., Green, J., \& Grenell, K. (2001). Local regimes: Does globalization challenge the growth machine? Policy Studies Review, 18: 49-62.

Clark, R (1955, October 17) Question arises from resolution: Location and use determine hospital's eligibility for Federal Funds. The Louisville Courier-Journal, section 2, p.1.

Clark, T.N. (1968).(Ed). Community structure and decision-making. Comparative analyses. San Francisco: Chandler Publishing Company.

Clarke, S.E. \& Gail, G.L. (1992). The next wave: Postfederal local economic development strategies. Economic Development Quarterly, 6: 189-198.

Clingmayer, J.C. \& Feiock, (1990). The adoption of economic development policies by large cities: A test of economic interest group, and institutional explanations. Policy studies journal, 18: 539-552.

Cochrane, A., Peck, J. \& Tickell A. (1996). Manchester plays games: Exploring the local politics of globalization. Urban Studies, 33:1319-1336.

Cochrane, A. \& Jonas A. (1999). Reimagining Berlin: world city, national capital or ordinary place? Eurpoean Urban and Regional Studies, 6: 145-164. 
Conant, R.W. (1968) The politics of community health. Washington, D.C.: Public Affairs Press.

Cooke, P. (1988). Municipal enterprise, growth coalitions and social justice. Local Economy, 3: 191-200.

Coomes, P.A. \& Narang R. (2001) Louisville's health related economy: Size, character, and growth. Retrieved August 6,2005 from www.healthenterprisesnetwork.com.

Council approves Jewish Hospital's plans for 152-bed addition (1970, May 15). The Louisville Courier-Journal, p.A18.

Council asks for fresh data on 2 institutions (1969, November 7). The Louisville Courier -Journal, p.B2.

Council for 9 counties ... health facilities unit plans to reorganize. (1968, October 11). The Louisville-Courier-Journal, p.A20.

Council gets $\$ 49,997$ Federal grant (1969, September 14). The Louisville Courier -Journal, p.B6.

Court clears way for new hospital: Zoning appeal for building on Clagett estate dismissed (1948, October 27), The Louisville Courier-Journal, section 2, p.1.

Council supports extension of family planning to whole region. (1972, June 8). The Louisville Courier-Journal, p.B19.

Cox, K.R. \& Mair, A. (1988). Locality and community in the politics of local economic development. Annals of the Association of American Geographers, 78: 307-325.

Dahl, R.A. (1961). Who Governs? Democracy and power in an American city. New Haven CT.: Yale University Press.

Davis, A. (2007, June 1). Jewish Hospital to run SW center. The Louisville CourierJournal. pp. D1, D2.

DeLeon, R.E. (1992). The urban antiregime: Progressive politics in San Francisco. Urban Affairs Quarterly, 27:555-579.

Dexter, L. A. (1970). Elite and specialized interviewing. Evanston, IL: Northwestern University Press.

Dispensa, J.M. (2004) Separation of use or misuse: Multifaceted empirical study of zoning variances. (Doctoral Dissertation Drexel University, 2004). Downloaded from the Drexel E-repository and Archives on March 2, 2008. 
Doctors favor east end site for Methodist hospital: Medical center plan opposed (1955, October 14), The Louisville Times, section 1, p.6.

Doctors' vote favors locating new hospital at medical center (1955, November 22), The Louisville Times, p15.

Domhoff, G.W. \& Dye, T.R. (Eds.) (1987). Power elites and organizations. Newbury Park, CA: Sage Productions

Dowding, K. (1995). Model or metaphor? A crucial review of the policy network approach. Political studies, 43: 136-158.

Dowding, K. (2001). Explaining urban regimes. International Journal of Urban and Regional Research, 25:7-19.

Drier, P. Mollenkopf, J. \& Swanstrom, T. (2001). Place matters: Metropolitics for the twenty-first century. Lawrence, KS: University of Kansas Press.

Duhl, L.J. (1986). Health planning and social change. New York: Health Sciences Press, Inc.

Dye T. R. (1973) Politics in states and communities (2ed). Englewood Cliffs, NJ: Prentice Hall.

Dye T. R. (1994 Politics in states and communities $\left(8^{\text {th }}\right.$ ed). Englewood Cliffs, NJ: Prentice Hall.

Eckstein, H. (1975). Case study and theory in political science. In F.I. Greenstein \& N.W.Polsby (Eds.), Handbook of political science: Vol. 7. Strategies of inquiry. Reading, MA: C Addison-Wesley Publishing Company.

Elkin, S. L. (1987). City and regime in the American republic. Chicago: The University of Chicago Press.

Elkins D.R. (1995). The structure and context of the urban growth coalition: The view from the chamber of commerce [Electronic Verson]. Policy Studies Journal, 23: $583-586$

Elling R.H. \& Lee, O.J. (1966). Formal connections of community leadership to the health system. The milbank memorial fund quarterly, 44:294-306. Retrieved March 3, 2008 from the Proquest database.

Englehart, P.J. (2000). Postwar changes in the urban Midwest: Different views of familiar territory. (Doctoral dissertation, University of Kansas, 2000). Digital Dissertations number: AAT 3002352. ProQuest document ID: 727912351. 
Feagin (1985). The global context of metropolitan growth: Houston and the oil industry. The American Journal of Sociology, 90:1204-1230. Retrieved on March 3, 2008 from the J-STOR Database.

Feiock, R.C. (1991). The effects of economic development on local economic growth. American Journal of Political Science, 35: 643-655.

Fendley, K. (1990) Citizen involvement and community growth preceding the installment of Toyota in Kentucky's golden triangle. (Doctoral dissertation, University of Kentucky). Digital Dissertations Number AAT 9035043. (ProQuest document ID: 744598421).

Finley, J. (1973, June 22). Health council will try to get hospital beds for the southwest. The Louisville Courier-Journal, p.A1.

Fleischmann, A. \& Feagin, J.R. (1987). The politics of growth-oriented urban alliances: Comparing old industrial and new sunbelt cities. Urban Affairs Quarterly, 23: 207-232.

Florida, R. (2002). The creative class: And how it's transforming work, leisure, community and everyday life. New York: Basic Books.

For falls region area, council hears health-care proposals (1972, March 24). The Louisville Courier-Journal, B1.

Foreman, S.D. (2003). The politics of professional sports facility subsidies in Florida. (Doctoral dissertation, Florida International University, 2003). Digital Dissertations number AAT 3128900. ProQuest document ID: 765914631.

Forsyth, D.R. (1983). An introduction to group dynamics. Pacific Grove, CA: Brooks/Cole Publishing Company.

Franklin plan cited: Condemnation right of $\mathrm{U}$ of $\mathrm{L}$ is upheld. (1957, June 22), The Louisville Courier-Journal, section 1, p.6.

Freeman, L.C. (1978). Centrality in social networks conceptual clarification. Social Networks, 1:215-239.

Friedland, R. \& Palmer, D. (1984). Park place and main street: Business and the urban power structure. Annual Review of Sociology, 10: 393-416.

Gentile-O'Donnell, D. (2004) An historical analysis of public politics, and healthcare delivery. (Doctoral dissertation, University of Pennsylvania, 2004). 
Gilbert, M.R. (1999) Place, politics and the production of urban space: A feminist critique of the growth machine thesis. In A.E.G. Jones \& D. Wilson (Eds.) The urban growth machine: Critical perspectives two decades later (pp.95-108). Albany, NY: State University of New York Press.

Gilliand, J.A. (2002) Redimensioning Montreal: Circulation and urban form, 18461918. (Doctoral dissertation, McGill University, 2002). Digital dissertations number AAT NQ78690. ProQuest document ID: 765627191.

Ginzburg, E. (1977) Regionalization \& health policy. Washington D.C.: U.S. Department of Health Education and Welfare. Public Health Service Health Resources Administration. DHEW Publication No. (HRA) 77-623 (Govt. Printing Office.

Gonzalez, G.A. (2002). Local growth coalitions and air pollution controls: The ecological modernisation of the US in historical perspective. Environmental politics, 11: 121-144.

Goodman, M. (2000). The "growth machine" reconsidered: Revitalization, gentrification and the culture of urban redevelopment. (Doctoral dissertation, Boston University, 2000). Digital Dissertations number AAT 9962633. ProQuest document ID: 731797011.

Gotham, K.F. (2000). Growth machine up-links: Urban renewal and the rise and fall of a pro-growth coalition in a U.S. city. Critical Sociology, 26:268-300.

Green, E. (2006, January 20) Hospital developers win in court: Ruling to allow doctors to build private hospitals in Southern Indiana. [Electronic Version] Business First of Louisville.

Green, E. (2007, February 16) LMCDC reorganization will shift control to university. [Electronic Version] Business First of Louisville.

Hainze, T.W. (1998). Water as a municipal growth limiting factor: Perceptions of the growth coalition compared with other civic leaders in arid southwestern cities. (Doctoral dissertation, Texas Tech University, 1998). Digital Dissertations number AAT 9912766. ProQuest document ID: 732987871.

Halebsky, S. (2004). Superstores and the politics of retail development. City \& Community, 3: 115-134.

Hamilton, J. (1948, September) A hospital plan for the Louisville Kentucky Area. Minneapolis: Author. Louisville Area Chamber of Commerce and Predecessors Records University of Louisville Archives and Records Center. 
Handleman, N.I., Townsend, H.L., Colbert, M., Ross, P, Waterman, N, Dwyer, G.G., et al, (1967) Hospital Committee. Jefferson County Medical Society Annual report. Jefferson County Medical Society Records, University of Louisville Medical School Archives, p 22-23.

Hanneman, R. A. \& Riddle.M. (2005). Introduction to social network methods. Riverside, CA: University of California, Riverside. Retrieved February 4, 2007 From http://faculty.ucr.edu/ hanneman/ )

Harding, A. (1991). The rise of urban growth coalitions, UK-style? Environment and Planning C: Government and Policy, 9: 296-317.

Harding, A. (1994). Urban regimes and growth machines: Toward a cross-national research agenda. Urban Affairs Quarterly, 29:356-382.

Harding, A. (1995). Elite theory and growth machines. In D. Judge, G. Stoker, \& H. Wolman (Eds.), Theories of urban politics (pp.1-35-53).London: Sage Productions.

Harding, A. (1999). Review article: North American urban political economy, urban theory and British research. British Journal of Political Science, 29: 673-698.

Harding, A., Wilks-Heeg, S., Hutchins, M. (2000). Business, government and the business of urban governance. Urban Studies, 37: 975-994.

He, W. \& Wu, F. (2006). Property-led redevelopment in post-reform China: A case study of Xintiandi redevelopment project in Shanghai. Journal of Urban Affairs, 27: 1 -23 .

Health council has a right to be impatient (1969, November 10). The Louisville Courier -Journal, p. A8.

Health planning unit sets public hearings on revised plans. (1969, June 27). The Louisville Courier-Journal, p. A8.

Health providers to file incorporation articles. (1966, September 16). The Louisville Courier -Journal, p. B5.

Hirsch, E.D. (1967). Validity in Interpretation. New Haven: Yale University Press.

Hill, K.Q. \& Durand, R. (1988). The "growth machine" revisited: Public and private sector elites' assessments of growth and growth policies. Social Science Quarterly, 69:737-745. 
Holloway, R.G., Artis, J.W. \& Freeman, W.E. (1963). The participation patterns of "economic influentials" and their control of a hospital board of trustees. Journal of Health and Human Behavior, 4: 88-99. Downloaded from the J-STOR database on June 9, 2006.

Hopes given new boost. (1969, June 12). Hopes given new boost. The Louisville Courier-Journal, p. B17.

Horan, C. (1991). Beyond governing coalitions: Analyzing urban regimes in the 1990s. Journal of Urban Affairs, 13: 119-135.

Hospital beds \& the move to efficient care. (1970, August 16 1970). The Louisville Courier-Journal, p. D2.

Hospital boosters want delegates on health panel (1972, January 16). The Louisville Courier-Journal, p. A18.

Hospital planners must consider medical teaching. (1969, February 17). The Louisville Courier-Journal, p. A8.

Howington, P. (2005, December 7). Southwest may lose hospital to northeast: Norton would preserve ER, outpatient services. The Louisville Courier-Journal, pp. A1,A5.

Howington, P. (2006, February 10). Norton accused of abandoning Southwest: Hearing considers relocating license. The Louisville Courier-Journal, pp. D1, D2.

Howington, P. (2006, October 22). Norton aims to build hospital of the future. The Louisville Courier-Journal, pp. D1, D2

Howington, P. (2006, August 17). Baptist East gets ok to add 112 beds. The Louisville Courier-Journal [Electronic Version].

Howington, P. (2006, November 8) Jewish's management structure cut by 42 posts: $1^{\text {st }}$ chief operating officer is named. . The Louisville Courier-Journal, pp D1, D2.

Howington, P. (2007, January 19) Norton unveils cancer initiative: Services to be taken into neighborhoods. The Louisville Courier-Journal, pp.A1,A5.

Howington, P. (2007, July 5). Norton unveils design of brownsboro hospital: Layout intended to avoid confusion. The Louisville Courier-Journal, pp D1, D2.

Howington, P. (2007, July 10). Partner hospitals leave University: Norton, Jewish led it to financial health. . The Louisville Courier-Journal, pp D1, D2. 
Howington, P. (2007, July 12). Plans for new medical center detailed: \$40 million facility will open next year. The Louisville Courier-Journal, pp D1, D2.

Howington, P. (2007, July 12). Haymarket site to be developed. The Louisville Courier -Journal, pp. D1, D2.

Howington, P. (2007, July 12). Plans for new medical center detailed: $\$ 40$ million facility will open next year. The Louisville Courier-Journal, pp. D1, D2.

Howington, P. (2007, September 27). Medical center names directors: Board oversees University Hospital. The Louisville Courier-Journal, pp D1, D2.

Howington, P. (2008, January 26). Baptist East awaits relief. The Louisville Courier -Journal, pp.D1,D2.

Howington, P. (2008, February 1). Hospitals seen as key players in Ky. Economy: Group says health-care cuts to impact local communities. The Louisville Courier -Journal, pp. D1, D2.

Hume, W.I, Brewer, M.S., Vonderharr, W.P. (1975) Falls Region Council Report. Jefferson County Medical Society annual report, 1974-75. Jefferson County Medical Society Records, University of Louisville Medical School Archives, p48.

Hume, W.I. (1978). Kentucky Health Systems Agency-West report. Jefferson County Medical Society annual report, 1977-78. Jefferson County Medical Society Records, University of Louisville Medical School Archives, pp. 32-33,

Hume W.I. (1980). Health Systems Agency-West liaison report. Jefferson County Medical Society annual report, 1979-80. Jefferson County Medical Society Records, University of Louisville Medical School Archives, p18.

Humphrey, C.R. \& Wilkinson, K.P. (1993). Growth promotion activities in rural areas: Do they make a difference? Rural Sociology, 58: 173-189.

Humphrey C.R. (2001). Disarming the war of the growth machines: A panel study. Sociological Forum, 16: 99-121. Downloaded from the J-STOR database on August 29, 2006.

Hunt, J.W. (2005) Community health centers' impact on the political and economic environment: The Massachusetts example. Journal of Ambulatory Care Management, 28:340-347.

Hunter, F. (1953) Community power structure. Chapel Hill NC: The University of North Carolina Press. 
Imbroscio, D.L. (2003). Overcoming the neglect of economics in urban regime theory. Journal of Urban Affairs, 25: 271-284.

Jepson, M.E. (2004). The impact of tourism on a natural resource community: Cultural resistance in Cortez, Florida. (Doctoral dissertation, University of Florida, 2004). Digital Dissertations number AAT 3135185. ProQuest document ID: 766034241.

Jewish Hospital parent seeks rights to Gateway Rehab beds (2008, February 7) [Electronic Version] Business first.

John, P. \& Cole, A. (1995). Models of local decision-making networks in Britain and France. Policy and Politics, 23:303-312.

Jonas, A. (1991). Urban growth coalitions and urban development policy: Postwar growth and the politics of annexation in metropolitan Columbus. Urban Geography, 12:197-22.

Jonas, A.E.G, \& Wilson, D. (1999). The city as a growth machine: Critical reflections two decades later. In A.E.G. Jones \& D. Wilson (Eds.) The urban growth machine: Critical perspectives two decades later (pp.3-18). Albany, NY: State University of New York Press.

Jordan, G. (1990). The pluralism of pluralism: An anti-theory? Political Studies, 38: 286 -301 .

Judge, D. (1995) Pluralism. In D. Judge, G. Stoker, \& H. Wolman (Eds.), Theories of urban politics (pp.13-34). London: Sage Productions.

Judge, D., Stoker, G. \& Wolman, H. (1995). Urban politics and theory: An introduction. In D. Judge, G. Stoker, \& H. Wolman (Eds.), Theories of urban politics (pp.1-12). London: Sage Productions.

Just born and already too limited. (1966, December 15). The Louisville Courier-Journal, P.A10.

Kearns, K.P. (2000). Private sector strategies for social sector success: The guide to strategy and planning for public and nonprofit organizations. San Francisco: Jossey-Bass.

Kelly, J.M. (1983). Mayoral leadership and community initiative: A survey of communities of the northeast. (Doctoral dissertation, Cornell University). Digital Dissertations number AAT 8309461, ProQuest document ID: 751722341. 
Kirby, A. \& Abu-Rass, T (1999) Employing the growth machine heuristic in a different political and economic context: The case of Israel. In A.E.G. Jones \& D. Wilson (Eds.) The urban growth machine: Critical perspectives two decades later (pp.213-225). Albany, NY: State University of New York Press.

Killmer, M.F. (2001). Projecting the future for neo-traditional developments: Lessons from growth machine impacts on the Chain-O-Hill neighborhood in the New Jersey. (Doctoral dissertation, University of Louisville, 2001). Digital Dissertations number AAT 3015247. ProQuest document ID: 728934451.

Kleber, J.E. et al. (2001). The encyclopedia of Louisville. Lexington: University of Kentucky Press.

Knoke, D. \& Kuklinski, J.H. (1982). Network analysis. Newbury Park, CA: Sage.

Krannich, R.S. (1980). Local social action and community growth: The impact of the growth machine on population change in small urban places, 1973-1978. (Doctoral dissertation, The Pennsylvania State University, 1980). Digital Dissertations number AAT 8107594, ProQuest document ID: 749727511.

Krannich, R.S, \& Humphrey C.R. (1983). Local mobilization and community: Toward an assessment of the "growth machine" hypothesis. Rural Sociology, 48: 60-81.

Krannich, R.S, \& Humphrey C.R. (1986). Using key informant data in comparative community research. Sociological Methods and Research, 14: 473-493.

Kuhn, T.S. (1970) The structure of scientific revolutions $\left(2^{\text {nd }}\right.$ ed.). Chicago: University of Chicago Press.

Kulcsar, L.J. \& Domokos, T. (2005). The post-socialist growth machine: The case of Hungary. International Journal of Urban and Regional Research, 29: 550-563.

Laumann, E.O. \& Pappi, F.U. (1973). New directions in the study of community elites. American Sociological Review, 38:212-230. Downloaded from the J-STOR database on January 19, 2008.

Laumann, E.O., Galaskiewicz, J., Marsden, P.V. (1978). Community structure as interorganizational linkages. Annual Review of Sociology, 4: 455-484. Downloaded from the J-STOR database on February 9, 2008.

Lay, B. (1971, March 23) COG makes agreements. New Albany Tribune., p.1, c.1.

Leichter, H.M. (1979). A comparative approach to policy analysis: Health care policy in four nations. Cambridge: Cambridge University Press. 
Lennarson-Greer A (1997) Urban Health Politics in R.K. Vogel (Ed.) Handbook of Research on urban politics and policy in the United States. (pp.356-371). Westport, CT: Greenwood Press.

Levine, M.A. (1994). The transformation of urban politics in France: The roots of growth politics and urban regimes. Urban Affairs Quarterly, 29: 383-410.

Lewis, R. D. (1993) Industry and space: The making of Montreal's industrial geography, 1850-1918. (Doctoral dissertation, McGill University, 1993). Digital dissertation number: AAT NN87635. ProQuest document ID: 747240341.

Litman, T.J \& Robins, L.S. (1984). Health politics and policy. New York: John Wiley and Sons.

Lloyd, G. \& Newlands, D.A. (1988). The growth coalition and urban economic development. Local economy, 3: 31-39.

Logan, J.R. (1976). Logan on Molotch and Molotch on Logan: Notes on the growth machine-toward a comparative political economy of place. The American Journal of Sociology, 82:349-352.

Logan, J.R. (1978). Growth, politics and the stratification of places. The American Journal of Sociology, 84:404-416. Retrieved on August 29, 2006 from the J -STOR Database.

Logan, J.R. \& Crowder, K.D. (2002). Political regimes and suburban growth, 1980 -1990. City and Community, 1:113-135.

Logan, J.R. \& Molotch, H.L. (1987). Urban fortunes: The political economy of place. Berkley University of California Press.

Logan, J.R. \& Molotch, H.L. (2007). Urban fortunes: The political economy of place with a new preface $20^{\text {th }}$ anniversary edition. Berkley University of California Press.

Logan, J.R., Bridges-Whaley, R. \& Crowder, K. (1997). The character and consequences of growth machines: An assessment of 20 years of research. Urban Affairs Review 32: 603-630.

Logan, J.R. \& Swanstrom T. (Eds.) (1990). Beyond the city limits: Urban policy and economic restructuring in comparative perspective. Philadelphia: Temple University Press.

Ludgin, M.K. (1988) The politics of urban redevelopment in Boston, Chicago, San Francisco, and Denver: The structure of the public/private partnership. (Doctoral dissertation, Northwestern University, 1988). Digital Dissertations number: AAT 8902661. ProQuest ID 745285671. 
Lyon, L, Felice, L.G., Perryman, M.R. \& Parker, E.S. (1981). Community power and population increase: An empirical test of the growth machine model. The American Journal of Sociology, 86:1387-1400. Downloaded from the J-STOR Database on October 28, 2006.

Martin, B.S. (1996). The efficacy of growth machine theory in explaining resident perceptions of community tourism development. (Doctoral dissertation, Clemson University, 1996). Digital Dissertations number AAT 9703468. ProQuest document ID: 739342921 .

Mayfield, L. (1996). The reorganization of urban politics: The Chicago growth machine after World War II. (Doctoral dissertation, University of Pittsburgh, 1996). Digital Dissertations number: AAT 9709396. ProQuest document ID: 739486921

McAvoy, P.V., Driscoll, M.B., \& Gramling, B.J. (2004). Integrating the environment, the economy, and community health: A community health center's initiative to link health benefits to smart growth. American Journal of Public Health, 94:525-527.

McGowan Mellor, G. (1992). Kosair Children's Hospital: A history 1892-1992. Louisville: Alliant Health System.

McGowan Mellor, G. (1988). Norton Hospital, the first hundred years 1886-1986. Louisville, KY: NKC, Inc.

McGranahan, D.A. (1984) Local growth and the outside contacts of influentials: An alternative test of the "growth machine" hypothesis. Rural Sociology, 49:530 -540 .

McKinlay, J.B. (ed.) (1984). Issues in the political economy of health care. New York: Tavistock Publications.

Medical care \& a faltering planning council. (1971, December 19). The Louisville Courier-Journal, p. E2.

Medical society will seek study of hospital plan. (1966, October 16). The Louisville Courier-Journal, p.A.34.

Methodist hospital assured at last (1956, June 7), The Louisville Courier-Journal, section 1, p.6. Methodist-hospital-site 99-year lease signed. (1958, January 16), The Louisville Courier-Journal, section 1, p.11.

Methodist opportunity at the Medical Center (1953, September 28), The Louisville Courier-Journal, section 1, p4.

Meyer, P. (1991). Local economic development: What is proposed, what is done, and what difference does it make? Policy Studies Review, 10:172-180. 
Mills, C.W. (1956). The power elite. New York: Oxford University Press.

Moffatt, S \& Freund, B (2004). Elite formation and elite bonding: Social structure and development in Durban. Urban Forces, 15: 134-161.

More beds unnecessary. Hospital needs action delayed. (1970, August 8). The Louisville Courier-Journal, p.A.24.

Mollenkopf, J.H. (1983). The contested city. Princeton, NJ: Princeton University Press.

Mollenkopf, J.H. (1996). How to study urban political power. In R.T. LeGates \& F. Stout. (Eds.) The city reader. New York: Routledge. (Originally published in 1992).

Molotch, H. (1976). The city as a growth machine: Toward a political economy of place. American Journal of Sociology, 82:309-332.

Molotch, H. (1976). Varieties of growth strategy: Some comments on Logan. The American Journal of Sociology, 82: 352-355.

Molotch, H. (1988) Strategies and constraints of growth elites. In S. Cummings (Ed.). Business elites and urban development (pp. 25-47). Albany, NY: State University of New York Press.

Molotch, H. (1993). The political economy of growth machines. Journal of Urban Affairs, 15:29-53.

Molotch, H. (1999) Growth machine links: Up, down and across. In A.E.G. Jones \& D. Wilson (Eds.) The urban growth machine: Critical perspectives two decades later (pp.247-265). Albany, NY: State University of New York Press.

Molotch, H. \& Vicari, S. (1988). Three ways to build: The development process in the United States, Japan, and Italy. Urban Affairs Quarterly, 24: 188-214.

Moran, M. (2006). Health policy. In B. G. Peters \& J. Pierre (Eds.), Handbook of public policy.(pp.219-230). London: Sage Publications.

Morone, J.A. (1982). The dilemma of citizen action: Representation and bureaucracy in local health politics. (Doctoral Disseration University of Chicago, 1982).

Multidimensional scaling. Retrieved September 9, 2007 from http://www.analytictech.com/networks/mds.htm.

Must reapply for U.S. funds. (1969, May 27). The Louisville Courier-Journal, p.B2. 
New hospital approved by Methodist Conference: Cost estimated at $\$ 4,000,000(1956$, June 6), The Louisville Times, section 1, p.6.

New hospital plans get close look (1969, April 19). The Louisville Courier-Journal, .A3.

North, P., Valler, D, \& Wood, A. (2001). Talking business: An actor-centered analysis of business agendas for local economic development. International Journal of Urban and Regional Research, 25:830-846.

Norton files to move beds from southwest to new hospital. (2005, December 6) [Electronic version]. Business First of Louisville.

Norton to keep Southwest Hospital, medical office buildings. (2005, December 21) [Electronic version]. Business First of Louisville.

Nunn, D, et al. (1973) Assessing health service needs in southwest Jefferson County. University of Louisville Archives and Records Center, Accession \#97-68, box 5 of 5 Center for Urban and Economic Research.

Old ways of health care inadequate. (1970, September 6). The Louisville Courier-Journal, p.H2.

Orum, A.M., Feagin, J.R. \& Sjoberg, G. (1991) Introduction: The nature of the case study. In J.R. Feagin, A.M. Orum \& G. Sjoberg (Eds.), A case for the case study. (pp. 1-26) Chapel Hill, NC: The University of North Carolina Press.

Paradis, T.W. (2002). The political economy of theme development in small urban places: The case of Roswell, New Mexico. Tourism Geographer, 4: 22-43.

Peirce, R.L. (1981, May 26). Reagan plans surgery on health planning systems. The Louisville Courier-Journal, p.1

Peterson, P.E. (1981). City limits. Chicago: University of Chicago Press.

Peterson, G.L. (2000). The role of local officials' social ties in balancing economic development and resource protection in Michigan's eastern Upper Peninsula. (Doctoral dissertation: Michigan State University, 2000). Digital Dissertations number: AAT 3000601.

Phelps, N.A., Parsons, N, Ballas, D., Dowling, A. (2006). Business at the margins? Business interests in edge urban politics. International Journal of Urban and Regional Research, 30:362-83.

Pickvance, C. (1995). Marxist theories of urban politics. In D. Judge, G. Stoker, \& H. Wolman (Eds.), Theories of urban politics (pp.253-275). London: Sage Productions. 
Pierre, J. (1999). Models of urban governance: The institutional dimension of urban politics. Urban Affairs Review, 34: 372-396.

Plano, J.A. (1999) Communities of interest: Making metropolitan hospital markets in Milwaukee and Toronto 1969-1994. (Doctoral dissertation: University of Wisconsin-Milwaukee, 1999).

Public can help name health council board. (1969, November 11). The Louisville Courier -Journal, p. B3.

Qian, Z. (2007). Institutions and local growth coalitions in China's urban land reform: The case of Hangzhou high-technology zone. Asia Pacific Viewpoint, 48:219 -233 .

Quilley, S. (1999). Entrepreneurial Manchester: The genesis of elite consensus. Antipode, 31: 185-211.

Razin, E. (1998). Location of entrepreneurship assistance centres in Israel. Tijdschrift voor Economische en Sociale Geografie, 89: 431-435.

Reese, L.A. \& Rosenfeld, R.A. (2002). Reconsidering private sector power: Business input and local policy. Urban Affairs Review, 37: 642-674.

Rainey, H.G. (2003). Understanding and managing public organizations ( $3^{\text {rd }}$ ed.). San Francisco: John Wiley and Sons.

Reihm, J. (1972, November 23). Critics urge council to revamp board. The Louisville Courier-Journal, p.A34.

Region to seek emergency service planning funds. (1972, July 20). The Louisville Courier-Journal, p.C1.

Rejection of Louisville health grant suggested (1969, May 21). The Louisville Courier -Journal, p. B24.

Robert Wood Johnson Foundation (2007, April). Communities in charge: Financing and delivering heath care to the uninsured grant results. Retrieved October 17, 2007 from http://www.rwjf.org/reports/npreports/cic.htm

Rosentraub, M.S. \& Helmke, P. (1996). Location theory, a growth coalition, and a regime in the development of a medium-sized city. Urban Affairs Review, 31:482-507.

Runyon, K. (1976, August 23). Community involvement led Mary Mullins to health agency role. The Louisville Courier-Journal, p. D2. 
Runyon, K. (1976, January 16). Council approved a new St. Joseph Infirmary. The Louisville Courier-Journal, p.B1.

Runyon, K. (1976, September 17). Council dissolves, is replaced by local arm of KY Health Systems Agency-West. The Louisville Courier-Journal, p. D3.

Runyon, K. (1976, May 14). Licenses denied to 2 abortion clinics. The Louisville Courier

Rutherford, G. (1973, August 31). In Louisville area, Medicorp official feels 'door open' for hospital. The Louisville Courier-Journal, p.A1.

Rutherford, G. (1974, January 15). Hospital plans meet a new snag. The Louisville Courier -Journal, p.A1, A18.

Rutherford, G. (1974, January 25). Regional health council approved southwest Jefferson County hospital. The Louisville Courier-Journal, p. A1.

Rutherford, G. (1974, February 28). New hospital gets state's approval. The Louisville -Courier-Journal, p.A1, A20.

Rutherford, G. (1974, May 9). Health council reapproves items. The Louisville Courier -Journal, p. B3.

Rutherford, G. (1974, May 9). Health council's fate is in Congress' hands. The Louisville Courier-Journal, p.D1.

Rutherford, G. (1974, November 1). Director of area health council resigns. The Louisville Courier-Journal, p. B1.

Ryan, E. (1973, October 25). Federal team to review operations of falls regional council. The Louisville Courier-Journal, p.B9.

Ryan, E. \& Rutherford, G. (1974, January 10). Study critical of Falls Region Health Council. The Louisville Courier-Journal, p. A1.

Rydin, Y. (1998). The enabling local state and urban development: Resources, rhetoric and planning in East London. Urban Studies, 35: 175-191.

Sackman, D.C. (1997). "By their fruits ye shall know them"” Nature, culture, and growth in California, 1869-1939. (Doctoral dissertation, University of California, Irvine, 1997). Digital Dissertations number: AAT 9806382, ProQuest document ID: 736607261 .

Savitch, H.V., Tsukamoto, T. \& Vogel, R.K. (2008). Civic culture and corporate regime in Louisville. Journal of Urban Affairs, 30:437-460. 
Savitch, H.V. \& Vogel, R.K, (2004). Suburbs without a city: Power and city-county consolidation. Urban Affairs Review, 39: 758-790.

Schaffer, A. (1989). The Houston growth coalition in "boom" and "bust." Journal of Urban Affairs, 11:21-38.

Schneider, M. (1992). Undermining the growth machine: The missing link between local economic development and fiscal payoffs. The Journal of Politics, 54: 214-230.

Schneider, M. \& Teske, P. (1993). The antigrowth entrepreneur: Challenging the "equilibrium of the growth machine. The Journal of Politics, 55: 720-736.

Schussler, N.C. (1994) A public-private partnership for providing indigent health care through corporatist mediation: A critical evaluation of the Humana partnership. (Doctoral dissertation, University of Louisville, 1994).

Scott, J. (1991). Social network analysis: A handbook. London: Sage Publications Ltd.

Shi, L. \& Singh, D.A. (2008). Delivering health care in America: A systems approach $\left(4^{\text {th }}\right.$ ed). Sudbury, MA: Jones and Bartlett.

Smart, A. \& Lin, G.C.S. (2004). Border management and growth coalitions in the Hong Kong transborder region. Identities: Global Studies on Culture and Power, 11:377-396.

Smith, A. (1776) The wealth of nations. (5 $5^{\text {th }}$ ed) New York: Random House.

Snow, D.A. \& Anderson, L. (1991) Researching the homeless: The characteristic features and virtues of the case study.In J.R. Feagin, A.M. Orum \& G. Sjoberg (Eds.), A case for the case study. (pp. 148-173) Chapel Hill, NC: The University of North Carolina Press.

Southwestern Jefferson County may get hospital. (1971, November 19). The Louisville Courier-Journal, p.B1.

Starr, P. \& Esping-Andersen, G. (1979, July-August) Passive intervention. Working papers for a new society, $7,15-25)$.

Starr, P. (1982) The social transformation of American medicine. New York: Basic Books Inc.

State recognizes Falls Council: Jefferson area gets official status for health planning (1970, April 6). The Louisville Courier-Journal, p.B10.

State to bail out Falls Region Council (1971, May 5). The Louisville Courier-Journal, p.B3. 
Statsoft Inc. (2003). Multidimensional scaling. Retrieved September 8, 2007 from http://www.statsoft.com/textbook/stimulsca.html.

Stoker, G. (1998). Governance as theory: Five propositions. International Social Science Journal, 50:17-28.

Stone, C.N. (1980). Systemic power in community decision making: A restatement of stratification theory. The American Political Science Review, 74:978-990

Stone, C.N. (1989). Regime politics: Governing Atlanta, 1946-1988. Lawrence KS: University Press of Kansas.

Stone, C.N. (1993). Urban regimes and the capacity to govern: A political economy approach. Journal of Urban Affairs, 15:1-28.

Stone, C.N. (2003) Power and governance in American cities. In J.P. Pelissero (Ed.) Cities, politics, and policy: A comparative analysis (pp.126-147). Washington D.C.: CQ Press.

Strom, E. (1996). In search of the growth coalition: American urban theories and the redevelopment of Berlin. Urban Affairs Review, 31: 455-481.

Swanson, B.E. (1 972) The politics of health. In H.E. Freeman, S. Levine, \& L.G. Reeder (Eds.), Handbook of Medical Sociology ( $2^{\text {nd }}$ ed.) (pp. 435-455). Englewood Cliffs, NJ: Prentice-Hall, Inc.

Tenhorst, P \& Van De Ven, J. (1995). The national urban growth coalition in the Netherlands. Political Geography, 14: 343-361.

The health council finally begins its difficult task. (1969, January 25). The Louisville Courier-Journal, p.A4.

Thomas, S.W. (1990) Changing medicine, constant care: Kentucky Baptist Hospitals. Louisville, KY: Baptist Hospitals Foundation, Inc.

Thomson, H.B. (1995) Martin Andersen and the rise of modern Orlando. (Doctoral dissertation The University of Alabama 1995) Digital Dissertations, AAT 9534261 (ProQuest document ID: 742116841 ).

Thornley and Newman (1996). International competition, urban governance and planning projects: Malmo, Birmingham and Lille [Electronic Version]. European Planning Studies: 4, 579-194. Downloaded from the Ebscohost Academic Search Premier database on January 17, 2008.

Tillett, R.S. (1980). Falls Region Sub-Area Council liaison report. Jefferson County Medical Society annual report, 1979-80. Jefferson County Medical Society Records, University of Louisville Medical School Archives, pp.18-19. 
Timmons, T.L. (1993). Structural speculation as a dynamic of urban growth: A case study of the Irvine Company. (Doctoral dissertation, The Fielding Institute, 1993) Digital Dissertations number AAT 9322573. ProQuest document ID: 747226001.

To plan 9-county program ... health advisory group receives $\$ 90,000$ grant. (1967, June 30). The Louisville-Courier-Journal, p.B1.

To study needs ... council urged to freeze new health projects. (1969, August 16). The Louisville-Courier Journal, p.B1.

Top fund priority urged for 2 city hospitals. (1969, March 7). The Louisville Courier -Journal, p.A1.

Troutman, P. (2004). A growth machine's plan B: Legitimating development when the value-free growth ideology is under fire. Journal of Urban Affairs, 26: 611-622.

Tulchinsky, T.H. \& Varavikova E.A. (2000). The new public health: An introduction for the $21^{\text {st }}$ century. San Diego: Academic Press.

U of L buys 8 hours on site for hospital (1957, April 24), The Louisville Courier-Journal, section $1, \mathrm{p} 6$.

University Medical Center Incorporated (1996). Affiliation agreement.

Unit chided for having no directors from poor. (1970, May 5). The Louisville Courier -Journal, p.B1.

Unless application approved soon . . council faces financial pinch. (1969, September 12). The Louisville Courier-Journal, p.B3.

Urges more effort in rehabilitation. (1970, February 20). The Louisville Courier-Journal, p. A6.

Vicari, S. \& Molotch, H. (1999). Building Milan: alternative machines of growth. International Journal of Urban and Regional Research, 14:602-624.

Vinsel asks V. A. to put its hospital downtown (1947, April 27), The Louisville Courier -Journal, section 1, p.14.

Vogel, R. \& Swanson, B. (1989). The growth machine versus the antigrowth coalition: The battle for our communities. Urban Affairs Quarterly, 25: 63-85.

Vogel, R.K. (1992). Urban political economy: Broward County, Florida. Gainesville: University of Florida Press. 
Vogel, R.K. \& Harrigan, J.J.(2007). Political change in the metropolis $\left(8^{\text {th }}\right.$ ed.). New York: Pearson Longman

Waddle, C. (1972, December 28). 7 Indiana counties lead falls region health unit. The Louisville Courier-Journal, p.A1.

Waddle, C. (1973, March 2). Aims to be more representative: Health council to change makeup The Louisville Courier-Journal, p.A9.

Waddle, C. (1973, March 29). Hollenbach supporting drive: Southwest hospital approval sought. The Louisville Courier-Journal, p.A1.

Waddle, C. (1973, June 8). Southwest hospital again an issue before council. The Louisville Courier-Journal, p.B1.

Wagner, H. (2005). Henry C. "Hank" Wagner: Retired president and CEO Jewish Hospital Healthcare Services in W.S. Butler et al (Eds.). Passing the Torch. Louisville, KY: Butler Books and Greater Louisville Inc.

Walton, J. (2000). [Review of the book The urban growth machine: Critical perspectives two decades later.] American Journal of Sociology 100:240-242.

Ward, J. (1969, July 1). To be replaced by Falls Region Health Council . . new falls area health council would omit Floyd, Clark Counties. The Louisville Courier-Journal, p.A12.

Warner, K. \& Negrete, J. (2005). The urban growth machine goes south: Conditions and capacities for more sustainable place building. Local Environment, 10: 571-593.

Wasserman, S. \& Faust, K. (1993) Social network analysis: Methods and applications. New York: Cambridge University Press.

Waste, R.J. (1986). Community power: Old antagonisms and new directions. In R.J. Waste (Ed.) Community power: Directions for future research. (pp.13-25)

Welch, W. (1971, December 14). A reporter's view: It's time the health council provided some leadership. The Louisville Times, p.A11.

Werner, L. (1973, June 20). Others would yield beds. Health panel modifies southwest hospital stand. The Louisville Courier-Journal, p.A1.

White, W.S. (1996). Growth machines, place entrepreneurs, and the social construction of ethnic enclave economies: An examination of Atlanta's Chinese enclave economy. (Doctoral dissertation, Georgia State University, 1996). Digital Dissertations number: AAT 9700598. ProQuest document ID: 739308581. 
Whitt, J.A. (1987). The arts coalition in strategies of urban development. In C.N. Stone \& H. Sanders (Eds.). The politics of urban development (pp.144-156). Lawrence, KS: The University of Kansas Press.

Whitt, J.A. (1988). The role of the performing arts in urban competition and growth. In S. Cummings (Ed.). Business elites and urban development (pp. 49-69). Albany, NY: State University of New York Press.

Whitt, J.A. (1989). Organizational ties and urban growth. In R. Perrucci \& H.R. Potter (Eds.). Networks of power: Organizational actors at the national, corporate, and community levels. New York: Aldine de Gruyter.

Wilson, D. \& Mueller, T. (2004). Representing "neighborhood" growth coalitions, newspaper reporting, and gentrification in St. Louis. The Professional Geographer, 56: 282-294.

Wilson, R.N. (1968) Community structure and health action: A report on process analysis. Washington, D.C.: Public Affairs Press.

Wood, A.M. (2004). Domesticating urban theory? US concepts, British cities and the limits of cross-national applications. Urban Studies, 41: 2103-2118.

Wood, A. \& Valler, D. (1998). Local business representation and the private sector role in local economic policy in Britain. Local Economy, 13: 10-27.

Zhu, J. (1999). Local growth coalition: The context and implications of China's gradualist urban land reforms. International Journal of Urban and Regional Research, 23:534-548.

Zingman B. \& Amster, B.L. (1997). A legendary vision: The history of Jewish Hospital Louisville, KY: Jewish Hospital Healthcare Services. 


\section{APPENDIX}

\section{BRIEF HISTORIES OF THE CURRENT HOSPITAL ORGANIZATIONS IN THE LOUISVILLE KENTUCKY METROPOLITAN AREA}

\section{Overview}

The following are the histories of the primary, existing hospital organizations in Louisville, Kentucky in 2008. The minor hospital organizations will be listed at the end.

\section{Baptist Hospital East}

The Baptist Healthcare System has a state focus with several facilities across Kentucky and two facilities in the Louisville area: Baptist Hospital East in St. Matthews and Baptist Hospital Northeast in LaGrange. The organization focuses its advertising efforts on Baptist Hospital East, which will be the focus here.

Baptist Hospital East had its origin with the founding of the Kentucky Baptist Hospital in the Highlands area of Louisville in 1924. In 1962, the administration and board members evaluated their mission in light of their aging facility and chose to build an entirely new facility in the eastern part of the metropolitan area. The decision to expand eastward was influenced by the organization's non-involvement in the Louisville Medical Center. The organization received approval to build the new facility in St. Matthews in 1970 and opened it in 1975 as a 253 bed unit (Thomas, 1990, 212-217).

The Baptist organization had two Louisville facilities for 14 years until 1989: Baptist Hospital East and Baptist Hospital Highlands. According to Thomas (1990) the St. Matthews facility emerged as the preference of both doctors and the general public 
and the Highlands facility declined. The organization ceased operations at the Highlands facility and sold it to Jefferson County Government, making Baptist Hospital East the base of local operation.

Baptist East continues to thrive and expand. Its new eight-story tower edition means that its edifice will utilize 51 percent of its 52 acres. The tower addition will add 112 beds making for a total of 519 . In addition to the growth on the Baptist East campus, the organization has plans to open an outpatient surgery center in the far eastern portion of Louisville-Jefferson County in 2009 (Howington, 2006, 17 August).

\section{Jewish Hospital-St. Mary's Healthcare}

Jewish Hospital-St. Mary's Healthcare (JHSMH) is the product of the merger between the Jewish Hospital Healthcare System (JHHS) and Caritas Health Services in 2005. The decision to merge was a strategic decision by JHHS and Caritas's parent organization Catholic Health Initiatives (CHI) of Denver, Colorado. JHHS had interest in expanding. CHI's view was that Caritas had viability problems as a stand-alone organization given the Louisville market. The merger was publicized as being in the interest of both the JHHS and CHI organizations. As part of the arrangement $\mathrm{CHI}$ and JHHS retain the deeds to their facilities. ${ }^{288}$

\section{Jewish Hospital Health Services}

JHHS has its origins in the opening of the Jewish Hospital in Louisville in 1905. This hospital was built with the intent of providing culturally sensitive healthcare for the Jewish community in Louisville (Zingman and Amster, 1997, p22).

\footnotetext{
288 The writer is a current employee of JHSMH and was so employed at a Caritas facility during the merger and had direct knowledge and experience of the rationale.
} 
The Jewish Hospital organization agreed in 1950 to become part of the Louisville Medical Center and become a teaching hospital for the University of Louisville. As discussed earlier in Chapter IV, its relocation was supported by the growth machine and it occupied its Louisville Medical Center facility in 1955.

Jewish Hospital thrived and expanded numerous times over the next 50 years. It assumed management of the Frazier Rehabilitation Center in 1984 (Zingman and Amster, p.142). Under the leadership of Hank Wagner, it expanded into hospital management, where it continues to contract to manage several hospitals in the region. It has been a center of international renown for research and multiple medical specialties, especially organ transplantation, heart surgery, and hand surgery. JHHS had begun to expand outside downtown by building an outpatient center in St. Matthews in 2000 .

\section{Caritas Health Services}

Caritas Health Services (CHS) was a distinctively Catholic healthcare provider in Louisville until its merger with JHHS. It consisted of two hospitals: Caritas Medical Center and Caritas Peace Center. Caritas Medical Center had originally been the Saints Mary and Elizabeth Hospital (SMEH) opened in 1874 by the Sisters of Charity of Nazareth. In 1958, SMEH moved to the south end of Louisville. Caritas Peace Center, a psychiatric hospital was originally opened in 1951 by the order as Our Lady of Peace Hospital (OLOP) to replace the Mount St. Agnes Sanitarium at the encouragement of the Hamilton Report (p. SR-4, Louisville Area Chamber of Commerce and Predecessors Records University of Louisville Archives and Records Center). In 1995 the Sisters of Charity of Nazareth Health System (SCNHS), which owned both SMEH and OLOP at the time, merged the two facilities into CHS and renamed the two facilities using the 
name Caritas (The Encyclopedia of Louisville, p.160). When the CHS organization was merged with JHHS, Caritas Medical Center and Caritas Peace Center were reverted to their old names (SMEH and OLOP) based on marketing research results.

JHSMH as a Merged Organization

As a merged organization, JHSMH has taken JHHS's growth momentum and has been aggressively expanding in the east and south ends of the Louisville Metropolitan Area. It has expanded the Caritas Physician Group (now The Physicians Group) from the south end into the east end with the opening of multiple sites. It has opened emergency rooms in the old (Norton) Southwest Hospital building, and in Bullitt County, south of Louisville, where it has recently had a certificate of need approved to build a 60 -bed hospital. The organization has purchased land in the far eastern part of Jefferson County for future development.

\section{Norton Healthcare}

The Norton organization was founded in 1881. It opened the John N. Norton Memorial Infirmary as an Episcopal hospital in 1886 at the corner of Third and Oak. It operated at that site until 1973 (Mellor, 1988, pp.13).

The 1948 Hamilton Report recommended that Norton expand at its site. There is an absence of any recommendation for it to become part of the Louisville Medical Center (p.SR-5, Louisville Area Chamber of Commerce and Predecessors Records University of Louisville Archives and Records Center). There is no evidence that the Norton Infirmary organization was part of the Louisville Area Development Association (LADA) discussions to create the Medical Center. 
The Norton organization grew by a number of mergers and acquisitions between 1969 and 1998. Mellor reported that Norton formed "a partnership with Children's Hospital in 1969 called Norton-Children's Hospitals" (p.7). In 1973, Norton-Children's moved to the Louisville Medical Center and then merged with the Kosair Crippled Children Hospital ${ }^{289}$ in 1981 under the umbrella of "NKC Inc." (p.61). In 1986 the organization spun the pediatric services off and opened the Kosair Children Hospital across the street from the Norton Hospital (Mellor, 1992, p. In 1989 NKC merged with Methodist Evangelical Hospital (MEH) to become the Alliant Health System (The Encyclopedia of Louisville, p.661). With the help of a Jefferson County bond issue Alliant purchased the three Columbia HCA hospitals (Suburban, Audubon, and Southwest) in Jefferson County in 1998. The Norton organization officially became Norton Healthcare in January 1999 to reflect its commitment to remain headquartered in Louisville (The Encyclopedia of Louisville, p.661).

As noted earlier in this dissertation, Norton has closed the Southwest Hospital it had acquired from Columbia HCA. It is transferring the beds to the new Norton Brownsboro Hospital scheduled to be opened in 2009.

Norton is currently the largest provider of healthcare services in the Louisville area. Besides the local facilities, Norton manages numerous facilities outside of the Louisville area.

\section{University of Louisville Healthcare}

University of Louisville Healthcare/U of L Healthcare is the assumed name of University Medical Center Inc (UMC). UMC is a $501 . c 3$ nonprofit organization and the

\footnotetext{
${ }^{289}$ Kosair Crippled Children Hospital was operated by the Kosair Charities and funded in part by the Kosair Shriners.
} 
fourth major healthcare provider in the Louisville Metropolitan Area. It was originally the Louisville City Hospital and then Louisville General Hospital as operated by the Jefferson County Board of Health. Historically, it has been the main provider of indigent care and a teaching hospital for the University of Louisville Medical School. Louisville General was taken over by the University of Louisville in 1979 and the facility became known as University Hospital.

The University of Louisville contracted management of the Hospital with proprietary firms between 1981 and 1995. Louisville-based Humana first managed the hospital between 1981 and 1993. Humana spun off hospital management to Galen Healthcare in 1993. Galen merged with Columbia Hospital Corporation and Hospital Corporation of America in 1993. In 1995 Columbia HCA moved its headquarters to Nashville, Tennessee breaking a term of the management contract with the state of Kentucky.

The state of Kentucky sought local management consortium and formed UMC in 1995 as a partnership with JHHS, Alliant Healthcare and the University of Louisville. In 2007, the University of Louisville invoked the termination clause of the consortium agreement out of conflict with the JHHS and Norton organizations over clinical specialty territories in the Louisville Medical Center.

As part of the thrust leading the dissolution of the UMC partnership, the University of Louisville has sought to create a " $U$ of $L$ brand" and create a continuum of care for patients. UMC has aggressively advertised its services. It has partnered with a private development firm to open a new $\$ 40$ million doctor's office building in the 
Louisville Medical Center, in competition with the office space provided by Norton and JHHS (Howington, 2007 July 12).

\section{Other Hospital Organizations}

The following are other healthcare organizations are operating at this time in the immediate Louisville Metropolitan Area. The reader is referred to the Encyclopedia of Louisville as a resource for past Louisville hospitals.

- Clark Memorial Hospital in Jeffersonville, Indiana is owned by Clark County, Indiana and is managed under contract by JHHS.

- Floyd Memorial Hospital is in New Albany, Indiana and is owned by Floyd County, Indiana.

- Kindred Hospital, a proprietary hospital, occupies the old St. Anthony Hospital facility. It was formally known as Vencor Hospital. It specializes in long-term care.

- Tenbroek Hospital is a proprietary hospital that specializes in psychiatric services at two locations in the East End. It is now owned by the same corporation as Wellstone Hospiral.

- The Veterans Affairs Medical Center is a facility ran by the Federal Government. It is a teaching hospital for the University of Louisville. There are plans for it to be replaced and the new facility to be built in the Louisville Medical Center.

- Wellstone Hospital is a proprietary hospital in Jeffersonville Indiana that also specializes in psychiatric services. It is now owned by the same corporation as Tenbroek. 


\section{CURRICULUM VITAE}

NAME: $\quad$ David P. Houvenagle

ADDRESS: 3103 Commander Drive

Louisville, KY 40220

DOB: $\quad$ Webster City, Iowa - June 12, 1965

EDUCATION

\& TRAINING: $\quad$ Northwestern College-St. Paul, Minnesota

1983-1985

B.A., Journalism-Mass Communication Iowa State University

1985-1987

M.Div., Pastoral Counseling and Ministries

Bethel University - St. Paul, Minnesota

1987-1991.

Clinical Pastoral Education

V.A. Medical Center-St. Cloud, Minnesota

1990

M.S.W., Direct Service

Southern Seminary

1992-1994

Ph,D., Urban and Public Affairs

University of Louisville

2001-2008.

INVITED PRESENTATIONS:

"How to do therapy while watching videos and being on the Internet" Indiana Council of Community Mental Health Centers, July 28, 2000, Indianapolis, IN.

"Using Video in Group Therapy" Our Lady of Peace Hospital, June 28, 2005. 
"Burnout prevention in residential child care work" Bellewood Children's Home, Anchorage, KY May 7, 2008 presented on behalf of Wayne Corporation.

"Understanding and managing anxiety" Norton Suburban

Hospital, Louisville, KY August 27, 2008 presented on behalf of Our Lady of Peace Hospital. 